African Dynamics in a Multipolar World 


\section{Africa-Europe Group for Interdisciplinary Studies}

Series Editors

Gregor Dobler, University of Freiburg, Germany

Elísio Macamo, Basel University, Switzerland

Editorial Board

William Beinart, University of Oxford, UK Filip De Boeck, Catholic University Leuven, Belgium

Patrick Chabal, King's College London, UK

Paul Nugent, Edinburgh University, UK

Nic van de Walle, Cornell University, Ithaca, USA

VOLUME 11 


\title{
African Dynamics in a Multipolar World
}

\author{
Edited by \\ Ulf Engel \\ Manuel João Ramos
}

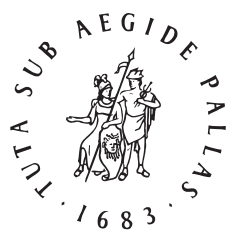

B R I L L

LEIDEN · BOSTON 
Cover illustration: Tuctuc taxi in Arada, Gondar (Ethiopia), March 2013. Photo by Sisay Sihale, edited by Manuel João Ramos.

ISSN 1574-6925

ISBN 978-90-04-25604-0 (paperback)

ISBN 978-90-04-25650-7 (e-book)

Copyright 2013 by Koninklijke Brill NV, Leiden, The Netherlands.

Koninklijke Brill NV incorporates the imprints Brill, Global Oriental, Hotei Publishing, IDC Publishers and Martinus Nijhoff Publishers.

All rights reserved. No part of this publication may be reproduced, translated, stored in a retrieval system, or transmitted in any form or by any means, electronic, mechanical, photocopying, recording or otherwise, without prior written permission from the publisher.

Authorization to photocopy items for internal or personal use is granted by Koninklijke Brill NV provided that the appropriate fees are paid directly to The Copyright Clearance Center, 222 Rosewood Drive, Suite 910, Danvers, MA 01923, USA.

Fees are subject to change.

This book is printed on acid-free paper. 


\section{CONTENTS}

About the authors vii

African dynamics in a multipolar world 1

Ulf Engel and Manuel Joao Ramos

Maputo home spaces:

Working for a Home, Working at Home

Ana Bénard da Costa and Adriano Biza

Changing patterns of intimacy among young people in Africa 29

Alcinda Honwana

Listening and archiving migrant voices: How it all began 51

Alessandro Triulzi

Overcoming the cost to Africa of being a good neighbour to Denmark:

Unconstrained geography as an alternative to the end of history.

John Davies

Corporate social responsibility in Africa: New trends for development?

A new field for African studies?

Virginie Tallio

Africa's demographics: a threat or a bonus?

Ana Pires de Carvalho

Doctoral studies in sub-Saharan Africa and the planned

RESSESA intervention

Paulos Chanie and Paschal B. Mihyo

Africa globalized?

Multipolarity and the paradoxes of time-space compression

Preben Kaarsholm

'The road to Sudan, a pipe dream?' Kenya's new infrastructural dispensation in a multipolar world 
The compulsion to do the right thing:

Development knowledge and its limits

Elisio Macamo

The study of Africa in a multipolar world

A perspective from within 195

Ebrima Sall

Index 


\section{ABOUT THE AUTHORS}

Adriano Mateus Biza is an anthropologist (Assistant Lecturer and Researcher) at the Department of Archaeology and Anthropology of the Eduardo Mondlane University (UEM) in Maputo, Mozambique. He graduated in anthropology at UEM and holds a MA in Arts on Critical Sociology and Anthropology of Development from the Institute for Social, Economic and Development Studies (IEDES); University of Paris I - Sorbonne, France. His research interests cover urban development, youth, sexual and reproductive health and environment.

Paulos Chanie has a PhD in Development Studies (2007) from the International Institute of Social Studies, Erasmus University, the Hague, Netherlands. He has been teaching at Addis Ababa University (AAU), Ethiopia, doing research and consulting national and international organizations in the areas of public policy and administration, development management, decentralization and civil service reform. He has published on public sector management, ethnic politics, neo-patrimonialism and fiscal federalism. He is currently an Assistant Professor at AAU and Director of Research at the Organization for Social Science Research in Eastern and Southern Africa (OSSREA).

Ana Bénard da Costa is a social anthropologist with a $\mathrm{PhD}$ in Interdisciplinary African Studies in Social Sciences (ISCTE, Portugal) and a researcher at the Centro de Estudos Africanos - ISCTE - Lisbon University Institute (ISCTE-IUL). Her research interests are on social and cultural change in Mozambican families, urban development, higher education and the informal economy. Since 2009 she is the editor of the peer-reviewed international journal Cadernos de Estudos Africanos.

Ana Pires de Carvalho is a demographer and has been a consultant in Mozambique, Angola and Sudan for UNFPA, UNOCHA, UNICEF and the World Bank. Previously, she taught mathematics and statistics at Eduardo Mondlane University (UEM) in Maputo, Mozambique. She also lead faculties in this university. She holds a Msc in Applied Mathematics and Computing (UEM) and a MSc in Operational Research (Southampton, United Kingdom). Later, she specialized in 
demography and has concluded a post-graduation course in demography in Princeton, USA, and a PhD in Demography and Social Statistics in Southampton, United Kingdom. Presently she is a senior researcher at the Center for Policy Analysis at UEM. Her main research interests are on fertility, mortality, poverty and linkages between rapid population growth and development.

John Davies holds a DPhil from the University of Sussex (Falmer), United Kingdom. He is a Visiting Research Fellow at the African Centre for Migration and Society (Witwatersrand University, Johannesburg, South Africa). His research interests are on borders, labor migration, gender and migration, vulnerable mobility and forced displacements.

Ulf Engel is Professor of African Politics at University of Leipzig. More recently he has been the editor of New Mediation Practices on African Conflicts (2012) and co-editor of Towards an African Peace and Security Regime (2013), Africa's New Peace and Security Architecture (2010) and Respacing Africa (2009). Since 2011 he has been a member of the AEGIS (Africa-Europe Group for Interdisciplinary Studies, Leiden) Advisory Council, and before that a 2004-2011a board member. He is also Professor Extraordinary of Political Science at the University of Stellenbosch, a fellow at the Stellenbosch Institute for Advanced Study (STIAS), South Africa, and a Visiting Professor at the Institute for Peace and Security Studies at Addis Ababa University, Ethiopia. His research interests include Africa's new peace and security architecture, changing notions of stateness in Africa and new spatialities of power in Africa.

Alcinda Honwana is a visiting professor in Anthropology and International Development at the Open University (OU), United Kingdom. Until 2010 she held a chair in International Development at the OU. Before joining the OU she was the Director of the Africa and the Children and Armed Conflict Programmes at the Social Science Research Council in New York, USA. She holds a PhD in Social Anthropology from the School of Oriental and African Studies of the University of London. Honwana's research interests cover issues such as: political conflict and its impact on children, youth and women; youth activism, participatory citizenship and involvement in processes of social change. Her latest books include Youth and Revolution in 
Tunisia (forthcoming, June 2013); The Time of Youth: Work, Social Change and Politics in Africa (2012); Child Soldiers in Africa (2006); and a co-edited volume Makers \& Breakers: Children and Youth in Postcolonial Africa (2005).

Preben Kaarsholm is Professor of Global and International Development Studies at Roskilde University in Denmark. Recent publications include Print Cultures, Nationalisms and Publics of the Indian Ocean (special issue of Africa, 2011); The Popular and the Public: Cultural Debates and Struggles over Public Space in Modern India, Africa and Europe (2009); and Violence, Political Culture and Development in Africa (2006).

Mark Lamont is a social anthropologist and lecturer at Goldsmiths, the University of London, with long-standing fieldwork in Meru, Kenya, originally on ritual and age-set formation, but more recently on accidental death in East Africa. Consistent with this focus, he is researching a book on the cultural history of road safety and automobility in Kenya, entitled, Speed Governors: Road Carnage and Infrastructural Politics in Kenya. He has previously published on various topics about Meru, such as mortuary practices, ritual abeyance, and gospel music.

Elisio Macamo is Assistant Professor of African Studies at the University of Basel, Switzerland. Before that he taught Development Sociology at the African Studies Centre in Bayreuth, Germany. He holds a MA in Translation and Interpreting (Salford), a MA in Sociology and Social Policy (University of North London) as well as a $\mathrm{PhD}$ and a Habilitation in Sociology (Bayreuth). His research interests include technologocal artefacts in urban settings, youth in Africa, poliitcal culture and authority, and South-South development cooperation. Recent publications include the monographs The Taming of Fate: Approaches to Risk from a Social Action Perspective - Case Studies from Southern Mozambique (2011), and Planícies sem fim (2008) as well as the co-edited volume Risk in Afrika: Conceptualising risk in contemporary Africa (2011).

Dr Paschal B. Mihyo is a Tanzanian, a lawyer by profession, a Professor of Politics and Administrative Studies with LLB, LLM and a 
$\mathrm{PhD}$ in public law from the University of Dar Es Salaam. He is currently Executive of the Organisation for Social Science Research in Eastern and Southern Africa (OSSREA) which position he has held since 2008. Between 1988 and 2004 he taught at the International Institute of Social Studies, a graduate School of Development Studies at Erasmus University in The Hague, Netherlands, where he was also Dean of Studies 1992-1995. From 2004 and 2005 he was Director of Research and Programs at the Association of African Universities in Accra, Ghana, after which he joined the University of Namibia briefly between 2006 and 2008. He has published twelve books and 31 journal articles on law, human rights, higher education and politics in Africa.

Manuel João Ramos is Professor of Anthropology at ISCTE - University Institute of Lisbon, Portugal, subdirector of its Centre of African Studies and head of the Central Library of African Studies. His recent publications range from studies on Ethiopian history, heritage studies to risk studies, including a scholarly edition of Pedro Paez's History of Ethiopia (2011), Ethiopian Stories (English edition forthcoming) and a number of books on road risk. He is presently a board member of AEGIS (Africa-Europe Group for Interdisciplinary Studies, Leiden). His present research interests are on Risk and Conflict studies, Heritage studies and Urban Anthropology. His regional area of research has been fpor some years the Horn of Africa.

Ebrima Sall is the Executive Secretary of the Council for the Development of Social Science Research in Africa (CODESRIA) in Dakar, Senegal, since April 2009. Prior to that, he had held senior positions in several institutions, including as Senior Programme Officer \& Head of Research at CODESRIA, and Senior Researcher at the Nordic Africa Institute (NAI) in Uppsala, Sweden. He holds a PhD in sociology from the University of Paris 1 Panthéon-Sorbonne. His research interests include higher education and the social sciences in Africa, conflict, citizenship and social movements.

Virginie Tallio holds a $\mathrm{PhD}$ in Ethnology and Social Anthropology from the École des Hautes Études en Sciences Sociales (France) in 2007. She worked as a research fellow at the Max Planck Institute for Social Anthropology (Germany) from August 2006 to February 2009. Since May 2009, she is a researcher at the Centro de Estudos Africanos 
do ISCTE-Instituto Universitário de Lisboa (Portugal). Her research interests include the use of public health policies as biopolitics, refugee camps as social space, the corporate social responsibility policies and their influence on the development arena and methods in anthropology, especially in sensitive contexts. She pursues research in Africa, especially in Angola. She holds as well a D.E.A. in Economic Demography of Developing Countries from the Institut d'Études Politiques de Paris (France).

Alessandro Triulzi is Professor of Sub-Saharan African History at the University of Naples 'L'Orientale', Italy. After he had served for many years on the board of AEGIS (the Africa-Europe Group for Interdisciplinary Studies) he became member of its Advisory Council in 2011. Triulzi has published extensively on 20th century Ethiopian history, colonial memory and post-colonial violence. Since 2007 he has been involved in recording migrant testimonies and narratives. In 2012, together with a group of migrants, media operators and researchers, has set up an Archive of Migrant Memories (AMM) in Rome to support migrant rights and agency through audio and visual productions. 



\title{
AFRICAN DYNAMICS IN A MULTIPOLAR WORLD
}

\author{
Ulf Engel and Manuel João Ramos
}

\section{Acknowledgments}

The editors wish to acknowledge and thank AEGIS, Brill Publishers and the Centre of African Studies at ISCTE-IUL, Lisbon, for the opportunity of publishing this book and having it ready in time for ECAS 5. We also wish to thank the contributors, who generously accepted our challenge, despite the usual problem in finding free moments in their busy academic schedules. We are particularly indebted to Clara Carvalho, CEA-IUL's director, for the financial support given for the revision and pagination of the book, and to Wendy Graça, who in spite of the pressure to have it published in due time managed to do the linguistic revision of the chapters, and to Rodolfo Soares, who worked round the clock to have the final version formatted and paginated in time for the conference.

\section{Introduction: The theme}

The coming 5th European Conference of African Studies (ECAS 5) which is being held on 27-29 June 2013 in Lisbon, Portugal, of which this book is partly a sneak preview, proposes to make the case that African Studies are a vibrant, productive and meaningful research and teaching area, uniquely capable of not only producing knowledge about Africa, but of gauging the viability of the decision-making processes, be it at grass-root or at the most macro of levels, through detailed analysis, thoughtful understanding and - let us admit - personal involvement.

The 2010s have witnessed the consolidation of most African states and institutions. However, fifty years after the foundation of the Organization of African Unity (OAU) in May 1963, the international panorama and Africa's position in it have changed considerably. The world's geopolitical and economic configuration has evolved, with 
new actors appearing in a new phase of globalization. Under these conditions and given its own trajectory, the current challenges that Africa faces include the promotion of peace and security, human rights, democratic institutions and particularly the integration and socio-economic development of Africans, as stated by the OAU's successor, the 2000-established African Union.

The new international political configuration has to consider the fall of old dictatorships in Africa, the role played by new political actors and unconventional forms of involvement such as those made possible by information and communication technology. From an economic perspective, the increasing importance of "emerging markets" such as Brazil, Russia, India, China and South Africa (i.e. the BRICS), with their own cooperation agendas, limited resources and growth and far-reaching effects on climate change and food security, have a strong impact on African economies and societies and their position in global forums. In social and cultural terms, the dynamism of African societies and their diasporas is evident in the ability of both individuals and groups to combine endogenous and exogenous elements and develop strategies to overcome the all too well-known odds. Such creativity is found in diverse areas such as cultural forums and academic debate and also in migration, trade, information and communication technology, health, social protection, the problems of youth and urbanization, and the reconfigurations of the socio-political and religious spheres.

It is of the greatest importance to look into Africa - its people, societies and institutions - and the possibilities of becoming a major player in the formation of the emerging post-Cold War, post-2000s US-hegemony new world order. The experiences that are appearing in Africa question many dominant paradigms in terms of political practice and academic reflection and thus offer a clear challenge to the academic community. For African scholars in particular, it is vital to play a key role in this endeavour. A number of questions that need to be addressed in this respect immediately come to mind:

- Is this impact globally positive or negative for African countries and African citizens?

- What disciplines should be applied, and in what way, to the situation and to gauge its probable consequences, both at a local and regional level? 
- What interdisciplinary means and tools should be brought in to produce an epistemologically relevant view (or narrative) of the issues under analysis?

- What epistemological preconditions, and what heuristic difficulties, may exist to hinder or shape analyses?

In view of this vast programme, the contributors to this book have in all modesty set about offering possible clues to research lines in African studies for upcoming years and to raise epistemological and methodological issues within the general theme of the book (and conference). Though these goals seem very ambitious, readers shouldn't expect any definitive answers here, in terms of a guiding systematic approach. Its editors and authors are only too aware that such elaborate theoretical constructs are yet to come about, and it is largely for those purposes that disciplinary and trans-disciplinary dialogue in conferences such as ECAS exist. Hence, we preferred, as is becoming the tradition of ECAS books (generally launched at the opening of each conference), to offer an assumedly essayistic, even heteroclite, but hopefully eye-opening window to possibilities of what African studies may offer to meaningful contemporary African issues.

\section{African Studies United}

On November 16, 2012, the Norwegian Students' and Academics' International Assistance Fund (SAIH) posted a video on YouTube as part of a mock aid campaign called "Radi-Aid: Africa for Norway". SAIH, a solidarity organization established in 1961 in the context of the anti-apartheid student movement in Norway, launched this campaign as a satirical take on the exploitation of negative stereotypes in fundraising campaigns originating in Northern countries and targeting Southern ones. The video rapidly went viral and soon reached more than two million views. It has been embedded in countless blogs and Facebook posts, and has enjoyed rapidly growing popularity, as can be gauged from social media stats. Directed by Matt Nefdt, a South African film director based in Durban, and produced by Devin Carter, of IKind Media Productions, the 3:45-minute video hilariously portrays the teaming up of Africans to gather used radiators to donate and ship them to freezing Norwegian citizens (because "frostbite kills too"); There follows a 
song that directly ridicules Band Aid. With the same tune and theatrics as the famous Bob Geldorf piece, a group of star African singers chants

In Norway kids are freezing, it's time for us to care. There's heat enough for Norway, if African should share. Yet Africans keep thinking we can't contribute. The warmth we've got, we'd like to share but we can't distribute. Now the tables have turned, now it's Africa for Norway. There's no way we can close our eyes, we see that they freeze. As Africans concerned, let's send our heaters all the way. Radi-Aid for Norway, etc.

It's fun, it's ironical, and even if it may sound a bit like biting the hand that has fed you it's an interesting sign of the times. In the great concert of nations, and in the greater concert of continents, Africa enjoys a previously unheard of protagonism. It is today's fastest growing continent, its demography is one of the healthiest, national democratic politics have finally taken off, as have higher education and regional economic integration. Corruption and cronyism are being tackled; accountability, capacity-building and entrepreneurship are buzz words of the day. Senses of hope and expectations of bright future seem to abound all over the continent.

Almost wherever one looks, there are great changes taking place. Africa is a continent on the move, enjoying new regional partnerships, looking for new opportunities, playing with new future expectations and facing newly reshaped problems: of adopting and adapting models of development that haven't proved their worth elsewhere, of coming to terms with the pains of excessive inequality, inefficient public sectors and infrastructural shortages. There are -well-founded fears of new neo-colonial scrambles, gaps in macro-economic sectorialisation, rising religious and "ethnic" tensions and profound rural-urban unbalances. But overall, as never before, Africa is becoming a self-defined identity, instead of an externally imposed categorical condition. It is as such that Africans are making a blatantly confident entrance in the global world arena of business, politics and culture. It's not totally obvious that "now the tables have turned", as the Radi-Aid song goes, but the fact that Africans can utter these words is momentous.

Much of this new African centrality is the making of African themselves, but one may contend that global multipolarity had a multiplying effect. Europeans and North Americans may retain key "partner" positions in many respects but no longer enjoy a monopolistic discursive and agential stance. In many respects, Africa may be seen today as a site of world power politics and predatory multinational business grabbing, 
but it is an open ground, not a closed backwater, and this gives Africans a growingly vocal say in the dictation and application of the rules of the game(s). This statement does not naively endorse the view that asymmetric power relations are miraculously being phased out but simply that intra- and inter-continental economic, cultural and political flows are becoming resolutely all-directional. Hence, there is no geographical centre of current globalization processes, and they don't lead to homogenization (fortunately "the world is flat" does not apply). Globalization can only be conceptualized in its plural.

In this respect, a most interesting conclusion of a recent conference on "Adaptation and Creativity in Africa" held in Maputo, Mozambique, under the auspices of the Deutsche Forschungsgemeinschaft (DFG), was that:

All projects work on Africa, and all work on technologies and significations in the production of institutional (dis)order, and finally all do so by focusing on the circulation of technologies and significations and their creative adaptations into ever new local contexts that thereby re-enact their global entanglements. ${ }^{1}$

Africa loves technological novelty, Africa is becoming entangled in globalization, Africa excels at creative adaptation; simply put, Africa works. This is the new mantra presently stealing the stage from the pervasive scenarios of doom of yesteryear. It seems as if Africans have had enough of the patronizing and negative stereotypes the North has recurrently projected upon them like a curse, and are standing steadfastly to an assertive self-confidence. This is definitively a departure from the old imagiological status quo.

It is of course a complicated matter to disentangle vision, rhetoric and reality when it comes to try labels such as "creativity", "adaptation" and "appropriation" to understand the recurrent tagging of contemporary African affairs. But the labels are there, and they are widely used in a variety of interconnected areas as floating signifiers - they reflect and produce meaning. But then again, it is an equally complicated matter to read the silences between the lines, to listen to what is being left unsaid, to sense what and who is being excluded. As the new African enthusiasm for vocalized connectedness, entrepreneurship and growth forges

${ }^{1}$ DFG Priority Programme 1448 "Adaptation and Creativity in Africa: Technologies and Significations in the Producion of Order and Disorder" (see <www. spp 1448.de >). This collaborative research programme started in 2011, will run for six years and comprises around 12 projects for every two-year funding period. 
ahead, there certainly lies a danger of forgetfulness, of silencing and of exclusion of the weak and voiceless.

With enthusiastic growth and development come newly found, or aggravated, conundrums. Speeded-up urbanization and mushroom-style infrastructuring, ultra-liberal business models and ultra-popularist party politics are breeders and harbingers of pangs of continental-wide headaches. These are to be easily expected, even predicted, because "we've seen this film before" in other regions, but unfortunately not so easily avoided, prevented or even mitigated. Such pangs come in a variety of forms: unsustainability - be it economic, energetic or environmental; unaccountability - be it financial, political or societal; unidentity - be it cultural, ethnic, or linguistic. On the whole, as much as a new Africa is being discursively and practically produced by African politicians, businessmen and intellectuals, a sort of de-Africanization is also well on the way, with grave risks: that of turning a blind eye to new contexts of victimization and marginalization on the one hand and that of fervently embracing external developmental models and naively assuming they are workable and inevitable.

Ironically, just as Africa is being declared the continent of the $21^{\text {st }}$ century and, as so many African countries catch the world's eye with double-digit growth records, many European and North American universities have been dismantling African Studies, arguing that it has become a redundant area of expertise. In a growing number of instances two contradictory tendencies thus seem bound to greatly condition the future of African Studies. On the one hand, the shrinking funding available for social sciences and the discursive paradigm that promotes inter-, pan-, multi- and transdisciplinarity sways all areas and results in constant degrading of disciplinary boundaries, growing reduction of allocable funds, limitation of career possibilities and downgrading of their relevance and authority. On the other, because these are increasingly dependent on international rather than national financing (this is especially true for the European region), abide by the thematic formatting and the ideology of social applicability of research calls from regional and national agencies. So, just as one could think that a regional studies area like African Studies, where interdisciplinary dialogue is so part and parcel of its standing, could not only survive these tendencies but actually thrive, it is interesting that in many places it faces a situation where research centres, university departments and teaching programmes are under great pressure. 
This is a new challenge, not devoid of some irony: European, and to a lesser extent North American research is compelled to move away from the traditional regional boundaries of area studies (some say as a result of the end of the Cold War, i.e. of geo-political, even military and intelligence interests in this kind of research - a causal stance that needs yet to be proved) and adhere to more fashionable fusion-style sorts - be it radical inter-disciplinarity (communication theory and anthropology, or economics and cognitive psychology, for instance) or glocally interwoven networking of post-modern flavour (decategorizing and recategorizing Africa in multi-identitarian Ocean studies, Africa under the tsunami of unbridled global capitalist system, etc). Others argue that important epistemological innovations have undermined the logic of area studies. Firstly, the so-called spatial turn with the reintroduction of space as an analytical category that allows us to question "areas" or "regions" and any other geographical scales on the basis of their constructed character (see Engel and Nugent 2009 on "Respacing Africa" which was also the motto of ECAS 3 held that year) and, secondly, the post-colonial turn which raises questions about the specific knowledge order which is at the bottom of all area studies. Thus, methodological nationalism and conceptual Euro-centrism are the two angles from which to rethink area studies in general and African Studies in particular. And while African Studies undergo institutional change in Europe and North America, African, South American and Asian counterparts are taking up the regional area - with new vigour, new visions, and old methods. The first Chinese and Indian studies centres are beginning to pop up in Africa, mostly in collaboration with already well-established African Studies Centres in China. The so-called areas have started to produce their own knowledge on the areas of this world, and at the same time Global Studies are making inroads in the Global South.

\section{The contents}

While some of the chapters have been written specially for this book, others are revisions and updates of previously published material. And, although continental affiliation wasn't a key factor in selecting the authors, it fortuitously turned out that we managed to bring together a well-balanced group of both African and European scholars. Since the book is thematic and results from a mixed process of personal invitation and call selection, we didn't deem it necessary to press for complete dis- 
ciplinary or regional representation. Readers from different disciplinary areas and those working in regions not touched upon here will hopefully find useful clues for further discussion and accretion in the present thematic and problematic approaches.

In writing the above blurb on current African dynamics and the possibilities of research in African Studies, it was our intention to sketch a general view that we felt reflected and compounded the lines of thought developed in the different contributions or chapters. In their chapter on "Maputo Home Spaces. Working for a Home, Working at Home", Ana Bénard da Costa and Adriano Biza analyze the spatial and demographic configuration of today's Maputo, the Mozambican capital with one million people living in the city and about two million in the metropolitan area - which is more the creation of those who inhabit the city than of those supposedly in charge of it. Attempts at imposing zoning regulations are invariably thwarted by private interests - business, commerce and families who put their savings and earnings into building homes in the different areas of the existing and emerging city. Building upon findings of the recently completed research programme "Home Space in the African City", this chapter examines the economic activities pursued by Maputo families in their attempts to obtain income and/or products for the acquisition, construction, transformation and upkeep of their home spaces. The economic activities pursued within the home space, and their implications for the residential structure of the home space, are also examined, along with the economic activities undertaken by women and young people and their impact in terms of gender and power relations

Alcinda Honwana explores "Changing patterns of intimacy among young people in Africa". Against the backdrop of soaring unemployment rates, she argues that these particularly affect the younger generation who are today grappling with a difficult transition into adulthood. After they leave school they are unable to obtain work or become independent - get their own house, support their relatives, get married, establish families and gain social recognition as adults. Using the notion "waithood", a portmanteau term of "wait" and "hood", meaning "waiting for adulthood", she analyses the practices of intimacy emerging from this period of suspension between childhood and adulthood. On the one hand, young people in waithood are no longer children in need of care but on the other they are still unable to become independent adults. 
In "Listening and Archiving Migrant Voices: how it all began" Alessandro Triulzi reports on a collective project based on Migrant and Refugee Studies and which he started a few years ago to record migrant voices and memories of African migrants and asylum-seekers in Italy. Collecting and sharing individual and group narratives involving "irregular" migrants and asylum-seekers basically from Ethiopia stimulated a participatory process of joint research and advocacy that led to the creation of a multi-media Archive of Migrant Memories. The idea of compiling an archive of memories made by and for migrants came out of a joint effort to make migrant memory a valuable good common to all and through it to build wider public awareness in Italy. The archive's aim was to put researchers and migrants together so as to allow migrants to participate directly in the collection and diffusion of their own stories and testimonies.

Looking at the contribution of geography to African Studies, in his chapter on "Overcoming the cost to Africa of being a good neighbour to Denmark: unconstrained geography as an alternative to the end of history" John Davies examines the multinational dynamics that impact on state-building and considers how notions of agency around state-building might be experienced by young Africans according to the globalizing practices and policies that are presumed to herald the end of history. The chapter particularly considers the impact of certain globalized presumptions regarding the desirability of "... getting to Denmark" (Fukuyama 2004, 30) and contests the essentialism that presumes all nation-states are able to follow a trajectory of institution building and development that will eventually result in a secure and safe capitalist society. In this context Denmark is examined and considered a specific nomenclature for any secure liberal democracy that operates as a capitalist market-driven society. Davies imagines a common post-modern border between an aged Denmark and a young Africa.

In a chapter on "Corporate Social Responsibility in Africa: New Trends for development? A New Field for African Studies?" Virginie Tallio posits that companies are now major actors in development. They act not only through their core activities but also their corporate social responsibility (CSR) policies. Though it is often described as being a Western concept, Tallio holds that CSR has its roots in cultural and social contexts. African studies, so the argument goes, can provide insightful results on the changes it involves in African societies. They can also explain what the African context can bring to this concept and 
these practices. It is assumed that African Studies will benefit from handling such research issues, just as classical CSR theoreticians, such as economists or management researchers, will profit from the insights of African Studies to refine their theories.

Preben Kaarsholm argues in his chapter "Africa Globalized? Multipolarity and the Paradoxes of Time-Space Compression" that the dynamics inherent in present-day transnational capitalism are having a major impact on the status of power and labour relations in South Africa's mining industry. He inspects the events that led to and followed the Marikana massacre (2012) and the disastrous way in which both the ANC-led neo-liberal government and the traditional labour unions have been handling spontaneous migrant miners' strikes. They seem caught in a paradoxical impasse, in that the country's striking economic growth that makes it a protagonist in the multipolarizing of the world hasn't been adequately reflected in the improvement of social conditions, particularly of migrant workers. The government's violence against them and the unions' dissociation from the unrest put them in the uncomfortable position of re-enacting apartheid's authoritarian and exclusionary practices.

In "The Road to Sudan, a Pipe Dream? Kenya's new infrastructural dispensation in a multipolar world", Mark Lamont critically deals with the costs of the drive for infrastructural expansion that is happening across Africa, fuelled by direct and growing involvement of international capital and foreign corporations and in particular the Chinese juggernaut participation in it. The overall argument is that the understanding of how neo-liberalism is reproduced through the infrastructural power of the nation-state through, as Lamont says, the "invisible traces of foreign investment" requires a detailed reading of the conflicts, negotiations and opportunism that it generates at local level. He provides such a reading in the case of Kenya's Lamu Port South Sudan Ethiopia Transport Corridor (LAPSSET) project, a massive development initiative designed by a swathe of non-local actors and agencies, both in terms of its internal political implications and its implications within the larger context of East Africa's infrastructural politics.

Elísio Macamo's chapter on "The compulsion to do the right thing: development knowledge and its limits" discusses the assumptions on which the knowledge supporting the international aid apparatus is based and the implications this has for Africa today. He analyses the Global Partnership for Social Accountability, a new World Bank ini- 
tiative based on the assumption that the success of national policies in developing countries crucially depends on the accountability of governments before their own society and is thus aimed at financing civil society organizations' watchdog programmes, and remarks that, while this initiative recognizes the failure of previous interventions, it relies on a presupposition lacking epistemological assessment that is inherent in the kind of knowledge produced by international development policies: that the vocation of this knowledge consists of translating problems of a political nature into technical problems requiring technical solutions. The shift towards promoting "good governance" of recipient countries is irrevocably connected to their governments' acceptance of an externally imposed agenda of neo-liberal reforms. His conclusion is that it is not African countries that have previously failed in their developing processes, but rather it the external attempt to engineer their development through "technical" intervention that miscarried. Hence, not tackling the epistemological failures of development knowledge will most probably result in further failures.

By scrutinizing the demographic dimensions of the changes occurring in Africa, Ana Pires de Carvalho's chapter "Africa's demographics: a threat or a bonus?" offers a vivid portrait of the complex intertwining of various indicators that shape today's Africa. By using cluster analysis to treat correlations between population growth and such factors as levels of technology, productivity, wealth distribution, work organization, people's education, social discipline and political systems, she concludes that African countries' demographics are healthy, in general terms, but criteria such as deficits in food availability and excessive fertility rates are important future threats to sustainable development that need to be taken into account by policy-makers and development agencies alike.

In their analysis of the history and present situation of higher education policies and realities in Africa, Paulos Chanie and Paschal B. Mihyo ("Doctoral studies in sub-Saharan Africa and the planned RESSESA intervention") detail the flaws, shortcomings, but also the virtues of decades of implementation of mostly European and American models of higher education in African countries. They also point out how the neglect of higher education in Africa in the past 30 years led to a braindrain that sorely reduced the capacity of African universities to foster the professional skills required to manage the continent's many problems. Their in-depth portrait of the conditions of most African universities, specially at post-graduate level, and the various limitations they face, be 
it knowledge production, promotion of systematic research, teaching quality, etc, more than justifies the need for qualifying, responsible intervention. The final section of the chapter is concerned with presenting the rationale behind the Research School for Social Scientists in Eastern and Southern Africa (RESSESA), a new higher studies capacity-building programme promoted by OSSREA in Eastern and Southern Africa.

Finally, Ebrima Sall in his chapter on "The Study of Africa in a multipolar world: A perspective from within", deals with the incommensurable challenge African scholars face today: that of de-centering theory, re-writing African and world history and defining innovative research agendas within African academies. Given both the enduring financial limitations of African higher education systems and their tendency for prioritizing STEM (science, technology, engineering and mathematics) within the framework of an "emerging global higher education space", Sall argues for the centrality of pan-African research institutions such as CODESRIA in what he defines as a urgent push for a more "equitable global epistemological order".

As editors of the present volume, we sincerely hope that readers with an interest in African issues and African Studies take it as a digest, in the ancient meaning of the term, i.e. as food offered for thought on its general theme, and on the paths, clues and interrogations shared by its contributors, in line with the spirit guiding the publication series associated with AEGIS' European Conference of African Studies.

\section{References}

Engel, Ulf and Paul Nugent (eds.) 2009. Respacing Africa (Africa-Europe Group for Interdisciplinary Studies Publication). Leiden: Brill Academic Publishers.

Fukuyama, Francis 2004. Getting to Denmark. State-Building: Governance and World Order in the 21st Century. Ithaca NY: Cornell University Press.

"Radi-Aid: Africa for Norway", ULR: <www.africafornorway.no >. 


\title{
MAPUTO HOME SPACES: \\ WORKING FOR A HOME, WORKING AT HOME
}

\author{
Ana Bénard da Costa and Adriano Biza
}

\section{Introduction}

In 2010, a team of three anthropologists (the authors and Judite Chipenembe) assisted by anthropology students carried out a fieldwork with 19 families living in ten different urban bairros of the metropolitan area of Maputo (Polana Caniço A, 3 de Fevereiro, Mahotas, Mavalane B, Hulene B, Magoanine B, Ferroviário, Albasine, Guáva and Jafar). This ethnographic study was one of the three components of the "Home space in African Cities" programme ${ }^{1}$ and took place in the part of Maputo that was known as Bairros de Caniço (reed) but as nowadays most houses are not made of caniço is called simple the Bairros.

Based on participative observation, non-directive interviews, life stories and family stories we sought to understand the meaning and importance of home space in the organization of families, and in the perpetuation or transformation of family structures and relations.

This concept home space - developed in a speculative sense by the research team of the programme "Home space in African Cities" - "re-

${ }^{1}$ This chapter draws on Costa and Biza (2012) and is part of the research programme "Home space in African Cities", funded by the Danish Research Council for Innovation 2009-2011, under the management of Prof. Jorgen Eskemose Andersen of the School of Architecture, Copenhagen. The programme was based on a conception and research design by Prof. Paul Jenkins of the School of the Built Environment, Heriot-Watt University / Edinburgh School of Architecture and Landscape Architecture. It was implemented in partnership between the above institutions (led by Professors Andersen and Jenkins), the Centre of African Studies at the ISCTE- Instituto Universitário de Lisboa (represented by Dr. Ana Bénard da Costa) the centre for Development of Habitat Studies in the Faculdade de Arquitectura e Planeamento Físico, Universidade Eduardo Mondlane, Mozambique (represented by Prof. Luís Lage, Prof. Julio Carrilho and Dr. Carlos Trindade) and the Faculdade de Letras e Ciências Sociais da Universidade Eduardo Mondlane (represented by Dr. Adriano Biza). The fieldwork was undertaken with participation of students of architecture and anthropology from Universidade Eduardo Mondlane, and had key involvement from architect Silje Erøy Sollien and the academic Judite Chipenembe. Generous support from the Mozambican institutions and time donated by Edinburgh and Lisbon institutions for their academics' inputs have been a key aspect of the programme's success. 
fers to the spaces within which the majority of African urban residents 'dwell' - 'dwelling' being both a place and a process. Creating 'home spac$e s$ ' thus involves spatial and social practices, but conceptually 'home' is above all else a culturally defined concept" (Jenkins 2012, 12).

With this innovative concept that inter relates physical, social, economic, cultural and temporal aspects of urban change, the research team of the programme "Home space in African Cities" besides offering, as Bourdieu ([1970]1992) and Moore (1984) taught long ago, an insight into the ways Maputo families position and project themselves within their social environment, merge in a single study unit the act of dwelling and the physical space of dwelling. Through this home space programme disciplinary boundaries (architecture, urban planning, economics and anthropology) were cut across and the micro-level understanding of the house as living space was related to wider urban development.

Currently the urban African development is taking place in an "arguably uniquely weak political and economic context...(that is)...leading to new forms of urbanism which challenge conventional values of what is 'urban' ... This new urbanism, dominated by households' use of space for living" (Jenkins 2012, 5-6), needs to be studied with the above mentioned new academic approaches within African Studies and following current trends in urban anthropology that besides qualifying understandings of governmentality (Nielsen 2011, Simone 2004) are revisiting aesthetics in the production of material life (Taussig 2012).

In this chapter we focus on the economic aspects in which these "urban spatially mobile populations" (Jenkins 2012, 5) are involved and that are directly related with their home spaces. Exploring the economic resources families and their members can draw upon to acquire, construct, modify and maintain their home spaces we aim to understand the way economic production and social reproduction are linked creating unique urban spaces and urban lives. ${ }^{2}$

The empirical data at our disposal shows that the economic resources available to each family varied according to the diversity of sources and the ways these resources are mobilized. Research on work and economic strategies of peri-urban Maputo families (Costa 2007, 2008) explain this diversity in terms of the characteristics of the families themselves (size,

\footnotetext{
${ }^{2}$ This ethnographic study was preceded by a built environment dwelling and household socio-economic study conducted in 2009-2010 (109 cases) and some of findings and date collected them is also used here (Andersen, Sollien and Ouis 2012; Andersen 2012
} 
composition, type, stage of domestic cycle) and other characteristics related with the resources available (within the family and external to it) and with the ability to mobilize, defend, maintain and transform these resources into income, dignity, power and sustainability (Bebbington 1999, 2022 and 2028-29). This process is strictly related with family linkages - and these can only be understood by extending the scope of analysis to encompass the different dimensions which structure the families (on the material, affective, symbolic, identity and value levels) and with the different trajectories and consequently the different frames of reference within which the families mobilize their resources (Costa 2007, 123).

Economic conditions are acknowledged as structural factors in the options followed by families in their economic strategies. As Loforte noted, families are permanently attempting to adjust to an uncertain social and economic context, and constantly recasting their life strategies in an attempt to respond in an articulated manner to changes in the socio-economic context. These changes are visible in the broader sphere of the national economy and employment market (exogenous factors); and in transformations within the family (endogenous factors). Both exogenous and endogenous factors have implications for the potential of families to generate resources enabling their survival and reproduction (Loforte 2000, 137-138).

The empirical study observed a wide diversity of situations allowing families to generate economic resources that enable their social reproduction and allow them to materialize their ideas and plans for the construction, transformation, organization and use of their home space. These practices involve and articulate many dimensions (social, economic and symbolic) and many types of resources (human, social, cultural and natural) (Costa 2007, 123).

\section{Working for a home}

Generally speaking, strategies and practices for achievement access to economic resources are activated at the interface between the socalled formal and informal economies. ${ }^{3}$ The families we studied, and

${ }^{3}$ The bibliography on the informal economy and its relations with the formal economy is extensive (AlSayaad and Roy 2004; Chen 2003; Grassi 2003; Hansen and Vaa 2004; Hugon 1999; Lopes 2008, Maldonaldo 1995; Roberts 1994; Yusuff 2011), and illustrates the diversity of ways of economic organization encompassed by the term, as well as the many ways formal and informal can interact (Hansen and Vaa 2004; Lopes 2008). Some authors argue that this concept "remains inadequate to ex- 
their members, structure their home space economies by participating in an articulated manner in economic activities and occupations which span both sectors, although it is the informal sector which tends to predominate. ${ }^{4}$

In the formal economy, there are different occupational trajectories that determine different ways of obtaining resources, saving and investing, and family reproduction strategies. Of the 19 families we studied, six heads of family work in the formal sector of the economy, although one of these is not a permanent resident of his bairro as he works as a miner in South Africa. The occupations of the other five heads of family (one female and the others male) are: clerk; contracted building worker; senior clerk at Eduardo Mondlane University (the female head of family); civil servant with the Ministry of the Interior; and administrator in a state bureau.

The remaining families obtain the income and produce they need from a wide range of "informal" economic activities. These activities range from services (lease of rooms, traditional healer, treatment of "traditional" illnesses, domestic employees, hairdresser, guards) to commerce (carried out in or outside the home, or as street vendors) and agriculture (cultivation of small vegetable patches on home premises, or on larger plots at a nearer or greater remove from the bairro), minor industry and carpentry / metal workshops manufacturing the goods, raw materials and technology necessary for the growing construction market in the bairros (doors, windows, frames, grilles) and basic domestic utensils (cookers, pots and pans) and the hire of construction materials (timber, shuttering) and, finally, income obtained via membership of a savings group or xitique. ${ }^{5}$

plain the dynamism of the informal economy in developing countries from its origin, causes and persistence" (Yusuff 2011,634) and that its complexity eludes the various theoretical approaches (modernization, dependency, neo-liberal and structuralist) that attempt to define it (Yusuff 2011). In the absence of an alternative definition and acknowledging the difficulties in avoiding this term (and its corollary, formal), and since an in-depth examination of the meaning(s) of the concept of the informal economy lies outside the scope of the present study, we use the term "informal economy" in the awareness that none of the proposed definitions fully encompasses the diversity of the economic situations they aim to address.

${ }^{4}$ As mentioned in the previous footnote, this distinction (formal/informal) does not reveal the structural logic of the mechanisms used for obtaining economic resources. In most of discourses and in the practices we observed, the reality that emerged was a complex one, characterized by a set of inter-related situations which occasionally reflected profound contradictions and which allowed families and their members to obtain economic resources for the satisfaction of their needs.

${ }^{5}$ The local term in Maputo for a rotating savings groups. 
Economic activities pursued on personal initiative and without involving any kind of contract, occasionally practised on a non-permanent basis (the so-called biscates) are predominant (these activities constitute the principal source of income for 11 families). In nearly all the families (15), economic income and/or available produce (for consumption and/or sale) derive from a combination of different activities exercised by various family members. The same family member may exercise more than one activity (in eight families there is at least one person involved in more than one economic activity). ${ }^{6}$ These sources of income may also be complemented by the lease of rooms (3), remissions from family members living in South Africa (2) or (in one family only) a pension. Some family members (7) mentioned that they received assistance in the form of money or produce from family members living elsewhere. In some cases these contributions are regular, and considered as their principal source of income; in other cases they are occasional, and are considered merely as "a bit of help".

As explained bellow in this chapter the social value attributed to these income- and produce-generating activities varies enormously, and this value does not stand in direct proportion to the resources gained by them. Different values are attributed to activities depending on whether they are performed by men or women, adults or children, and on the nature of the activity itself. Some activities are not considered as work; others are.

The importance of agriculture in the economic activities pursued by Maputo families (Sheldon 1999, 2002, 2003) is borne out by the fact that it is mentioned in most (12) cases. And the fact that everyone who practises some form of agriculture emphasizes its importance to the domestic economy (regardless of quantity, variety, regularity or value) attests to the continuing preponderance of rural activities in the economies of urban families, in this study at least. Even those who no longer practise agriculture have practised it in the recent past, citing various reasons for giving it up. Some, for instance, sold their machamba to get what

${ }^{6}$ Recourse to economic activities which combine complementarity of activities with pluriactivity, and in many instances entail the geographic dispersion of the family's members, has been observed in other studies in the same or similar contexts (Andrade 1998; Costa 2007; Loforte 2000). However, the articulation of diversified sources of income is not a strategy exclusive to the peri-urban Maputo families, nor even of families living in urban and rural milieu in sub-Saharan Africa, or other "developing" regions (Creed 2000). It also occurs in the "developed" world (Barlett 1993, Lima 1992). Creed relates the emergence of this strategy not only with situations of economic crisis but also with the flexibility of the global economy $(2000,9)$. 
they needed to build the house they now live in; others left agriculture because they only practised it when young, when living in their parents' house; for others, the machamba was a long way from their home and they lacked the money to get there.

In cases where the resources obtained from agricultural work are mentioned, the cultivation plots are located in the yards of the family's home spaces and are small vegetable patches, or agricultural plots in the bairro of residence or in other areas or more rural bairros (normally low-lying land), in locations outside the city or even outside the province of Maputo. In the latter cases, family members either go there regularly to work the land or live there permanently. Then there are some families who have loaned or leased their machambas. There are still cases where work on the machambas is by specially contracted labour. The machambas are often located well outside the city (20 to 40/50 kilometers distance from their houses), but as we shall explain below they are still associated with the home space, for not only are they a relatively important resource for the survival of the family, they also have performative effects on the organization of domestic life.

Different members of the same family, not necessarily living in the same home space or belonging to the same household, often perform work on the same machamba. This demonstrates the persistence and importance of family connections across diverse nuclei of the same family, and also reveals a series of social dynamics, which, though based on agriculture, are structured and maintained in the urban milieu. Agriculture is pursued not only for strictly economic reasons, but also, and perhaps essentially, because it perpetuates (albeit in combination with other factors) the family and social ties which are essential for the survival and reproduction of the family in the urban milieu.

In the life stories related to we observed that many of the strategic options in the search for economic resources are shaped and influenced by past experiences and skills, both personal and occupational. These are present-moment situations that take shape in a constantly ambiguous and contradictory dialogue between the ideal and the possible. A significant proportion of the families members whom we studied (most of them with irregular incomes) made reference to the growing discrepancy between their everyday reality and their socio-economic aspirations and expectations.

One of the characteristics of family economies is the exchange of goods and services between members of the same extended family, 
who may or may not share the same home space. These exchanges - "a bit of help" in their words - are part of the mutual rights and obligations established via practices of reciprocity rooted in traditional kinship rules. However, observance of these practices is now limited to a narrower group of relatives (and even then they are not always observed) with closer ties of kinship (fathers, sons, brothers, nephews). This family network of exchange, mutual assistance, duties and responsibilities is one of the most important ways of facing up to the economic constraints to which the families are subjected. This system - whereby a family member feels obliged to provide assistance, or to which he or she resorts when necessary -, helps each family secure the financial means and/or consumer goods necessary for meeting their basic requirements, while it may also make additional resources available.

\section{Working at home}

In only a few of the families we studied (5) was the home space merely a place of residence and social reproduction. Most (14) also pursue economic activity in their home space; in some cases this activity is complementary to other activities pursued outside the home space, while in others it actually constitutes the principal source of income and involves one or more family members, working part- or full-time. ${ }^{7}$ In addition to requiring changes to the spatial configuration of the house, these activities provide monetary resources and/or foodstuffs that are considered important for the domestic economy, although just how important varies according to the type of activity and the volume of production.

In addition to growing vegetables on small patches in their yards, some families have modified parts of their home spaces to accommodate other types of income-generating activity. These include vending ( 7 cases), craft industry ( 2 cases) and services ( 5 cases). To facilitate their vending activities, families build barracas in or at the front of their plots, ${ }^{8}$ small takeaways or groceries where they mainly sell food

\footnotetext{
${ }^{7}$ The Built Environment Study (Andersen, Sollienen and Ouis 2012) observed that economic activities were pursued in the home space in almost 60 per cent of cases.

${ }^{8}$ The part of the yard beyond its perimeter but running immediately alongside it is considered to belong to the home space, as other research in the same context has verified (Costa 2007).
} 
and drinks, and bancas - stalls set out on the street adjacent to their plots - where household members, mainly women and children, sell small kits of various basic products.

In the cases of a blacksmith, a carpenter and a traditional healer, their places of work are within the home space, which they have built and/or modified to serve their purposes: and this implies the separation of work and living zones, with common areas in which both customers and family members can circulate: the yard or patio. In other cases, where the income-generating activity is sporadic (an example is a woman who treats children with traditional remedies) or the home space is used for storing products that are sold outside economic activity does not entail structural modifications: but it does nevertheless interfere with the domestic space (clients coming and going, products stacked in bedrooms etc.).

Lease of rooms in the main house or annexes/outhouses, called "dependências" ( 3 cases) is another activity which provides the families with income, ${ }^{9}$ and which also entails some reorganization of the domestic space.

Analysis of the facts reveals not only a symbiosis between domestic activities and the generation of income which erodes the traditional spatial distinctions between reproduction (non-economic activities) and production (economic activities); it also, and above all, shows that the balance in the use of space between residence and workplace varies according to income, aspirations of the household, the nature of the economic activities pursued, and the alternative income-generation opportunities which emerge, among other variables. It was also shown that the performance of the different activities in the home space entails multiple and complex combinations of human, material, symbolic and spatial resources, which are not always managed in harmonious fashion by the different family members. Economic activities pursued in the home space - observed in 14 of the cases we studied - were mainly the responsibility of women (11), who occasionally mentioned the assistance of other family members (7) and some are considered to be the family's principal source of sustenance (6), but only three of these activities were unequivocally considered to be work (a man

\footnotetext{
${ }^{9}$ In the 109 cases addressed by the socio-economic and physical survey (Andersen 2012, Andersen, Sollienen and Ouis 2012), only seven cases of leased living space were recorded. The survey did however suggest the emergence of a important market for room rental.
} 
who has a metal workshop at home, a couple in which the wife does mukera, ${ }^{10}$ and a traditional healer).

In addition to the relatively diverse range of economic activities pursued in the home space, another income-generating activity is of a financial nature, and rotates around the homes of its members: xitique. In most cases only women take part in a xitique scheme, although one case involving a couple was observed.

In all the cases we studied where the head of the family was a man, when questioned on all the decisions relating to the obtaining and allocating of the material resources necessary for the acquisition, construction, upkeep and transformation of the home space, the responses of family members - including the head of household himself suggested that the decisions had been taken by men. These decisions often involved complex choices, given the limited resources. Deciding whether to channel investments and savings into home improvements (and what kind), or the education of the children, or even to formalize the conjugal union, involves choices that attend to the different needs and priorities of the various male and female members of the family. Normally, the man's will prevails and his power of decision is not (openly, at least) contested, for this power lies with him naturally.

It is no easy task to analyse this assistance in terms of the power relations it embodies, or to determine whether it is given on a regular basis, whether it is freely given or imposed upon the weaker by the stronger, whether failure to give it entails punishment, what kind of management underlies it, or who exercises it and in relation to what kind of expenditure. It would also require more fieldwork than we were able to conduct. Nevertheless, in several cases we obtained information from different family members on the way individual contributions to the common family revenue are processed, and these allow us to make some tentative guesses on the management of income in the home space.

\section{Gender and power relations in the home space}

The first factor to consider is that the person seen as in charge of the home space is always the head of the family, whether male or female. Everyone else who contributes funds, regardless of amount or fre-

\footnotetext{
${ }^{10}$ This refers to the process of buying products in neighboring South Africa and re-selling in the south of Mozambique - a well-established economic activity. Someone who dos this is called a Mukerista.
} 
quency, are seen as helpers. Although in practice they are also responsible for the upkeep of the family, the women who were the partners of the heads of family also saw themselves, in most cases, as "helpers".

All the other activities which women may pursue (vending, ${ }^{11}$ agriculture) and from which they derive income or produce are not seen as work, regardless of the importance of the resources thereby obtained for the upkeep of the family. "My husband doesn't let me work. The only thing he permits is [me] selling from the booth here in the house" (female aged 36, 3 de Fevereiro).

The men on the contrary, even when unemployed or doing sporadic work (biscates) and earning wages insufficient to sustain their families, are always seen as the ones in charge, even where they recognize that they are unable fully to exercise this function due to lack of resources. At the same time, in all the cases observed, the women pursue some kind of activity (on a more or less regular basis) that generates income and/or produce.

However, the fact that women are involved in income-generating activity does not of itself qualify them for an improvement in their status. For as we have seen, such activities are not seen as work, and to pursue them women need the authorization of their husbands - which is not always given. In one case, for example, the husband declared:

\begin{abstract}
"The one who pays all the expenses of my family is me, I'm the one who works ...I have a machamba in Guijá but it's my wife who works it, not me." His wife adds: "I don't work, my husband doesn't let me work, I don't sell anything either. At home, in Guijá, I started selling but my husband doesn't like it. ..."
\end{abstract}

The fact that women often pursue income-generating activities inside the home space or in family-owned machambas ${ }^{12}$ which, regardless of how close they are to the houses they live in, they have always considered as part of their family space has important implications. On the one hand these activities belong to the domestic space, where the woman has always exercised a degree of control and power. Therefore

${ }^{11}$ As observed in an earlier study (Costa 2007), vending activities are not seen as work.

${ }^{12}$ The importance of agriculture was also verified in the Built Environment Study (Andersen, Sollienen and Ouis 2012), which found that 36 per cent of the households included in the sample had a machamba in the green areas or another location remote from the plot of land they lived on. In most cases (75\%), the machamba yielded only enough for consumption by the family. Only one machamba in four produced a surplus for market, thereby contributing to the family income. 
it socially acceptable for them to pursue these activities: but by the same token, such activities are not considered to be work. Yet many of them involve contact with the outside world (clients) and as such require the authorization of the husband. Where economic activity in the home is pursued at the initiative of the man, however, ${ }^{13}$ it is considered to be work.

Economic activities pursued by women and associated, in practice or symbolically, with the domestic sphere do not, for this reason, entail changes to their status, which continues to be related to the family and to their roles as wives and mothers. And while their access to the financial resources, which their activity procures, is something new relative to the old practices in the rural milieu, this does not of itself bring about any change in gender relations, in terms of or increased autonomy and power, or less inequality, with regard to men. The roles traditionally assigned to women remain the same. They are the ones who are responsible for the domestic chores but the boys or the men can perform this work, where there is no woman in the house. And in many of the cases we studied, the males did perform certain tasks: they washed their clothes, swept the floor, sometimes cooked. This distribution of tasks by gender depends on the relative proportions of males and females in the house, and their ages; but the mother, whenever she is present, is the one who is ultimately responsible for them.

Thus, and as this study ${ }^{14}$ shows, the fact that women exercise activities which bring them monetary income does not necessarily signify - as some authors (Tripp 1989; Loforte 2000) suggest - that they have access to certain positions of power, or can achieve a certain visibility at bairro level which can positively influence their status inside and outside their families. These activities do not of themselves contribute to an increase in their self-esteem, to greater control over their own lives or to more bargaining power vis-à-vis men. In fact, they may even end up penalizing women more than benefitting them (Caplan 1995; Campbell 1995; Rocha and Grinspun 2001), for they entail a greater workload than in the rural milieu.

Children and young people often contribute to the family budget too. The form of these contributions, and the extent to which they

${ }^{13}$ This ethnographic study records only one such instance, but data from the socio-economic study (and from other studies too) carried out as part of the same project confirm this observation.

${ }^{14}$ Confirmed in other studies: see Costa (2007, 2005); Caplan (1995); Campbell (1995); Rocha and Grinspun (2001). 
are made freely or coercively, largely depend on the type and structure of the family to which they belong (number of resident members, age distribution, the economic situation of the family and the types of income-generating activities on which it depends), the social representations of the different family members with regard to the duties and responsibilities allocated to different generations, and the different places and social roles played by each member of the family. These social representations are not uniform across age groups, in each particular age group, or even at individual level. There are always different ways of interpreting the norms embodied in the cultural models which co-exist in the context we are examining, and this can generate conflict between family members - conflict that tends to become more acute the tighter the economic straits the family finds itself in.

The economic contributions of children and young people to their family budgets can be either direct or indirect. Direct contributions derive from activities which yield income or produce. The monetary gains resulting from these activities are totally or partially incorporated in the family budget, while in other cases the activities may be pursued as part of family businesses or ventures (helping out at vending stalls, in family-based industry, working on the machamba), with the income from these activities managed by the family member(s) responsible. Indirect contributions occur in instances where children and young people perform all kinds of domestic tasks (cooking, looking after younger children, cleaning the house, washing clothes, fetching water) which release the older family members from these responsibilities and enable them to exercise income-generating activities.

Direct contributions are more frequent among older children (sons and daughters) and those who are no longer in education. In some cases, older sons already have children of their own and live with their wives in their parents' home. They feel - or are - obliged to make some kind of contribution. This obligation to help may extend to children who have already left home, and in four cases mention was made of non-resident children who contribute to the upkeep of their parents' home space. And as we saw, in another three cases other non-resident relatives (brother and sisters) provide help too.

In similar fashion to what occurs with activities that yield income and/or produce and are exercised by the women of the family, however, receiving "a bit of help" (regardless of how much, and with what frequency) does not call into question the supremacy of the head of 
the family over the other members of the household. Where there is a couple in the household, it is the man who is in charge, for he works while the others do biscates; and in the case of the women and younger members of the family, the activities they pursue are only considered to be work if they are regular, and remunerated in the form of a salary which presupposes some kind of employment contract. ${ }^{15}$

\section{Conclusions}

In their efforts to obtain resources and to reproduce, family members resort to a plurality of activities which generate income and products. These activities span all sectors of the economy (formal, informal, primary, secondary and tertiary); they take place in different geographic contexts (urban, rural and even other countries); and in most cases no single activity generates income sufficient to meet the needs of the families. Situations like this necessitate constant exchanges and sharing, structured around family relations which extend beyond the nucleus of residents of any individual home space. The social value attributed to the different activities depends not only on the type of activity pursued or the income or products which are the outcome of the activity; essentially, it depends on the status enjoyed by the individual pursuing the activity. We observed that the economic activities pursued by men have a different social value from the activities pursued by children, youths and women. Only where the activities of the latter are pursued as part of formal employment contracts are they actually seen as work

The internal management of the income and products obtained by the different family members in the activities they pursue depends on numerous factors ranging from power relations to normative codes and individual/collective affects and interests. Another factor is that the income or products resulting from these activities are often unpredictable, and in most cases are not guaranteed in advance. Many such activities require a degree of wheeling and dealing, knowledge of demand and the ability to imagine and anticipate future developments if a minimum amount of success is to be achieved vis-à-vis the competition. Other activities depend on social relations, knowledge and exchanges of favors. Others, like farming, depend on the climate and are founded on ancestral knowledge which includes the awareness of risk and lack

${ }^{15}$ This was observed in only one instance in this study. The only exception was that of the traditional healer, for reasons already given. 
of security. Consequently, the unpredictability and lack of security that characterize the urban milieu the families currently inhabit are nothing new. If anything, in fact, the city offers a wider range of possibilities for "playing" on various fronts.

Yet this potential can only be realized by combining different activities and simultaneously cultivating the social relationships on which such activities depend. And in cultivating these social relationships, actors embody behaviors and values which, depending on interests and circumstances, can actually be mutually contradictory.

Therefore, as we have seen, it is these multiple articulations and interrelations between different income - and produce-generating activities, different types and levels of social relations, and different behaviors governed by values which are sometimes contradictory, which define the modernity and urbanity of the families in the context under analysis.

The conjugation of these apparently dissimilar but inter-dependent attitudes generates contradictions in the discourse of social actors. These contradictions become apparent in the comparison of discourses in which representations of normative ideals from different cultural models are evident (the practices of the actors are often in contradiction with their discourse).

We conclude that the social and/or economic relations between actors are simultaneously a resource in themselves and a means to obtaining other resources. Some of these resources are given freely, as a means of creating or maintaining dependency, on the basis of which relationships of power and prestige are established within a given family, social group or network. Thus, doing business and the value of what is transacted frequently depend on pre-existing social relationships between the parties, or on relationships which the actors wish (or wish not) to establish.

\section{References}

AlSayaad, Nezar and Ananya Roy eds. 2004. Urban informality: transnational perspectives from the Middle East, Latin America and South Asia. Lanham: Lexington Books.

Andersen, Jorgen E. 2012. "Home space Socio-Economic Report." Copenhagen: The Royal Danish Academy of Fine Arts, School of Architecture, Department of Human Settlements. http://www.homespace.dk/tl_files/uploads/publications/ Full\%20reports/HomeSpace_Socio-Economic_Study.pdf (accessed June 10, 2012). 
Andersen, Jorgen E., Silje Sollienen and Khadidja M. Ouis. 2012 "Home space Built Environment Study". Copenhagen: The Royal Danish Academy of Fine Arts, School of Architecture, Department of Human Settlements. http://www.homespace.dk/ tl_files/uploads/publications/Full\%20reports/HomeSpace_Built_Environment_ Study.pdf, (accessed June 10, 2012).

Andrade, Ximena et al. 1998. Famílias em contexto de mudanças em Moçambique. Maputo: WLSAMOZ/CEA.

Barlett, Peggy F. 1993. American Dream, Rural Realities: Family Farms in Crises. Chapell Hill: University of North Carolina Press.

Bebbington, Anthony. 1999. "Capitals and Capabilities: A Framework for Analyzing Peasant Viability, Rural Livelihoods and Poverty”, World Development, 27 (12): 2021-2044.

Bourdieu, Pierre. 1992 (1970). “The Kabyle house or the world reversed." In The Logic of Practice, Pierre Bourdieu, 271-283. Cambridge: Polity Press:.

Campbell, John. 1995. "Conceptualizing Gender Relations and the Household in Urban Tanzania”, In Gender, Family and Household in Tanzania, edited by Colin Creighton, 178-202. Aldershot: Avebury.

Caplan, Pat. 1995. "In My Office We Don't Have Closing Hours': Gendered Household Relations in a Swahili Village in Northern Mafia Island". In Gender, Family and Household in Tanzania, edited by Colin Creighton, 118-138. Aldershot: Avebury.

Chen, Martha. 2003. "Rethinking the informal economy: in an era of global integration and labor market flexibility". New Delhi Seminar No531, November.

Costa, Ana B. 2005. "Género e poder nas famílias da periferia de Maputo". Lusotopie 12 (1-2): 203-216.

Costa, Ana B. 2007. O preço da sombra: sobrevivência e reprodução social entre famílias de Maputo. Lisboa: Livros Horizonte.

Costa, Ana B. 2008. "Trabalho e imaginação nas famílias da periferia de Maputo". Nova Africa 22: 31-50.

Costa, Ana B. and Adriano Biza. 2012. "Understanding 'Home space' in the African city: Ethnographic Report”. Copenhagen: The Royal Danish Academy of Fine Arts, School of Architecture, Department of Human Settlements,. http://www.homespace.dk/tl_files/uploads/publications/Full\%20reports/HomeSpace_Ethnographic_Report_text.pdf (accessed June 10, 2012).

Creed, Gerald W. 2000. "Family Values' and Domestic Economies". Annual Review of Anthropology 29: 329-355.

Grassi, Marssi. 2003. Rabidantes. Comércio espontâneo transnacional em Cabo Verde. Lisboa: Imprensa de Ciências Sociais.

Hansen, Karen T. and Mariken Vaa, eds. 2004. Reconsidering informality. Perspectives from Urban Africa, Nordiska Afrikainstitutet.

Hugon, Philippe. 1999. Economia de África. Lisboa: Vulgata.

Jenkins, Paul. 2012. "Home space Context Report". Copenhagen: The Royal Danish Academy of Fine Arts, School of Architecture, Department of Human Settlements. http://www.homespace.dk/tl_files/uploads/publications/Full\%20reports/HomeSpace_Context_Report.pdf (accessed June 10, 2012).

Lima, Antónia P. 1997. “Trabalho de campo com famílias da elite empresarial de Lisbon: um terreno para a análise e o exercício das relações de poder", Ethnologia 6/8: $105-122$. 
Loforte, Ana M. 2000. Género e poder entre os Tsonga de Moçambique. Maputo: Promédia.

Lopes, Carlos M. 2008. "Economia Informal e Processos de Organização". Janus 2008, Anuário de Relações Exteriores: 134-135. Lisbon: UAL/Público. http://www.janusonline.pt/2008/2008_4_2_4.html (accessed April 7, 2009).

Maldonaldo, Carlos. 1995. “The informal sector: Legalization or laissez-faire?”. International Labour Review. Vol. 134, No. 6, Geneva: ILO: 705-728.

Moore, Henrietta L. 1984. Space, Text, and Gender. An Anthropological Study of the Marakwet of Kenya. New York: The Guilford Press.

Nielsen, Morten. (2011). "Inverse governmentality: The paradoxical production of peri-urban planning in Maputo, Mozambique." Critique of Anthropology. 31(4): 329-358.

Roberts, Bryan. 1994. "Informal Economy and Family Strategies“. Journal of Urban and Regional Research 18 (1): 6-23.

Rocha, Mercedez G. De La and Alejandro Grinspun. 2001. "Private Adjustments: Households, Crises and Work", Choices for the Poor: Lessons from National Poverty Strategies, UNDP, http: //www. undp.org/dpa/publications/ choicesforpoor/ ENGLISH/CHAP03. PDF. (accessed May 15, 2002).

Simone, AbdouMaliq. 2004. For the City yet to Come. Changing African Life in Four Cities. Durham: Duke University Press.

Sheldon, Kathleen. 1999. "Machambas in the city. Urban women and agricultural work in Mozambique." In Lusotopie 1999: Dynamiques religieuses en lusophonie contemporaine. L. M. Silva, ed. Paris: Éditions Karthala: (accessed June 10, 2012).

Sheldon, Kathleen. 2002. Pounders of grain. A history of women, work and politics in Mozambique. Portsmouth, NH: Heinemann.

Sheldon, Kathleen. 2003. "Markets and gardens. Placing women in the urban history of Mozambique." Canadian Journal of African Studies 37(2-3):358-395.

Taussig, Michael. 2012. Beauty and the Beast. Chicago, University of Chicago Press. Tripp, Aili M.1989. "Women and the Changing Urban Household Economy in Tanzânia". Journal of Modern African Studies, 27:601-23.

Yusuff, Olabisi S. 2011. "A Theoretical Analysis of the Concept of Informal Economy and Informality in Developing Countries". European Journal of Social Sciences, V. 20, No 4: 624-636. 


\title{
CHANGING PATTERNS OF INTIMACY AMONG YOUNG PEOPLE IN AFRICA ${ }^{1}$
}

\author{
Alcinda Honwana
}

\section{Introduction}

Young people in Africa constitute the majority of the population with more than 42 per cent under the age of $15 .{ }^{2}$ While the continent has experienced considerable economic growth in the past decade, it has not translated into job creation and greater socioeconomic equity. Soaring unemployment rates have particularly affected the younger generation who are today grappling with a difficult transition into adulthood. After they leave school they are unable to obtain work and become independent - get a house for themselves, support their relatives, get married, establish families and gain social recognition as adults. These attributes of adulthood are becoming increasingly unattainable by the majority of young people in Africa. I use the notion 'waithood's, a portmanteau term of "wait" and "hood", meaning 'waiting for adulthood, to refer to this period of suspension between childhood and adulthood. On the one hand, young people in waithood are no longer children in need of care; but on the other, they are still unable to become independent adults. While chronological age defines them as adults, socially they are not recognized as such. Rather than defining youth on the basis of age categories (for example 15-24 or 15-34) this chapter understands youth as a social construction based on societal expectations and responsibilities; thus it considers all those who have not yet been able to attain social adulthood, despite their age, as youth.

${ }^{1}$ This chapter was first published in Alcinda Honwana. The Time of Youth: Work, Social Change and Politics in Africa. Sterling VA: Kumarian Press, 2012. This is an abridged version of the the original chapter.

${ }^{2}$ See 2008 Africa Population Data Sheet, The Population Reference Bureau. Available at: http://www.prb.org/pdf08/africadatasheet2008.pdf (accessed 11 March 2013).

${ }^{3}$ The notion of waithood was first used by Singerman (2007) and Dhillon and Yousef (2009) in their work on youth in the Middle East and North Africa.

${ }^{4}$ The United Nations and the World Bank define youth as those aged between 15 and 24, and the African Union's definition of youth covers the age range 15-34. See: United Nations (2007); World Bank (2007); and African Union (2006). 
Waithood represents the contradictions of modernity, in which young people's opportunities and expectations are simultaneously broadened and constrained. They are enlarged by the new information and communication technologies - mobile phones, cyberspace, television and advertising - that make young people more globally integrated. At the same time, they relate to local social structures and cultural patterns and are constrained by lack of access to good education and secure employment as well as by political instability and epidemics such as HIV/AIDS. Young people are involved in an intricate struggle between constraints and limitations, on the one hand, and freedoms and opportunities on the other. Young Mozambicans use the Portuguese term desenrascar a vida, eke out a living; young Senegalese and Tunisians employ the French term debrouillage, making do; and young South Africans speak about "just getting by." All these expressions vividly convey the extemporaneous nature of these young people's lives.

Waithood is transforming young people's intimate ties and sexual relationships. In a context of chronic unemployment, precarious livelihoods and reduced marriage rates, the interconnections between political economy, intimacy, and sexuality become critical for understanding the coping strategies adopted by young people in waithood (Hunter 2010). Sexuality, courtship and marriage are undergoing profound changes that are inextricably linked to the particular socioeconomic conditions faced by this generation. Sexuality and intimacy appear to play a more material role in everyday life, and are becoming fertile grounds for constructing and refashioning personal and collective identities (Bhana et al. 2007).

This chapter draws from in-depth interviews with young people carried out between 2008 and 2011 in Mozambique, Senegal, South Africa and Tunisia. It examines young people's strategies for coping with waithood, carving out innovative 'youthscapes' (Maira and Soep 2005) and establishing new sets of social and intimate relationships to deal with their often precarious and vulnerable situation.

The chapter makes two main arguments. First, in a context of unemployment and resource scarcity, intimacy and sexuality become more commoditized livelihood assets (Chant and Evans 2010) as young women and men engage in relationships with older, more affluent men and women known as "sugar daddies" and "sugar mamas" who function as providers. These relationships are not simple commercial exchanges, as they involve continuing and reciprocal obligations between partners 
that include gifts, support and services, and may involve personal affection. Second, through these new forms of sexual relationships, young women and men are redefining female and male sexuality and challenging existing notions of masculinity and femininity.

\section{Young women, sugardaddies and boyfriends}

Many young women and men I interviewed in the course of this study dream of obtaining modern consumer goods and enjoying the "good life" rather than existing in deprivation and uncertainty. The fashionable jeans, sneakers, hair extensions and cell phones they see paraded in hiphop music videos, soap operas, movies, and magazines from the West become objects of desire. Young people use all means available to them, including their sexuality, to gain access to consumer goods. At the same time, struggling to cope with an independence they cannot sustain financially, they long for protection, emotional support and affection.

According to Thandeka ${ }^{5}$, a twenty-three-year-old South African woman, "There is a lot of peer pressure and girls want to look modern. It is all about getting fashion, hair, and bling. Girls hook up with older men with money, who provide all that and sometimes more. Some girls can get cell phones, televisions or even cars. ... It depends on how rich and powerful the man is."

Relationships in which young women engage in sex with older, financially stable partners, often called sugar daddies, in exchange for gifts and money are common across Africa (Hunter 2002; Longfield 2004; Hawkins et al 2009; Chant and Evans 2010; Masvawure 2010). These relationships have become more prevalent because so many young men cannot afford to provide for and marry their girlfriends. Young people's difficulties in finding employment and forming families put considerable strain on their intimate and sexual lives.

The sugar daddy is an important factor driving young women's sexual relationships and brings to the fore what Mark Hunter (2002) calls the "materiality of everyday sex," underscoring the role that gifts play in relations between men and women. Hunter (2010) distinguishes between romantic love and provider love, which are often interconnected. Sugar-daddy relationships constitute a form of transactional sex or provider love because they are based on the exchange of sex for gifts.

${ }^{5}$ This is not her real name. Throughout this chapter I use pseudonyms to protect the identity of my interlocutors. 
While there are some similarities between these relationships and commercial sex work, not all forms of transactional non-marital sexual relations should be seen as prostitution, as they may involve continuing ties and reciprocal obligations that go beyond the predetermined payment (Standing 1992; Castle and Konaté 1999; Kaufman and Stavrou 2004; Leclerc-Madlala 2003; Hunter 2002; Cole 2004; Thomas and Cole 2009).

Nancy Luke (2005) distinguishes between two types of transactional sex, one that includes gift exchanges and another that involves commodity exchanges. Gift exchanges take place in the context of personal relationships and may include services such as cooking and job advice. In commodity exchanges such as prostitution, sexual activity takes place in the market and is traded for its monetary equivalent. But sugar-daddy relationships, which are mainly seen as gift exchanges, retain a certain degree of ambiguity, as in some cases they may be perceived as closely akin to prostitution. ${ }^{6}$

Tsitsi Masvawure (2010) takes issue with the transactional sex literature on Africa that sees sugar-daddy relationships solely as means of economic survival (Chatterji et al. 2004; Luke and Kurz 2002; Machel 2001). She points out that not all women involved in transactional sexual relationships are 'victims'. Some seek these relationships in order to attain an otherwise elusive modern lifestyle; others prefer to avoid the burdens of emotional commitment and sexual exclusivity attached to standard boyfriend-girlfriend or marital relationships (Masvawure 2010). Indeed, there is great diversity and complexity in the exchanges and obligations of partners.

At the age of twenty, Mariana is enrolled in the 11th grade at a secondary school in Maputo. She grew up in Boane and moved to Maputo to pursue a high-school education, staying at a relative's house on the outskirts of the city during the week. Although her elder brother helped with her school fees, she always struggled to find money for transport, food, clothing, and toiletries. Occasionally she braided hair to earn some cash. Then she realized that other girls from similar backgrounds were able to afford a much better lifestyle and buy things that she could not. Mariana wanted to be like them. So she started seeing an older man whom she called a patrocinador (sponsor). They would meet for sex two or three times a week and he would give her money and gifts. Mariana

${ }^{6}$ While commercial sex work and sex trafficking also affect young women, the purpose of this chapter is to focus on relationships with sugar daddies and sugar mamas and examine how these relationships contribute to changing patterns of intimacy and gender relations among young men and women in waithood. 
justified her actions, saying, "I am a poor girl, but I have ambitions. ... I want to buy nice school supplies, I want nice clothes and I want to have fun like the other girls. ... If I don't look for it myself, nobody is going to do it for me. ... I have to survive and live as best as I can." Mariana also mentioned the affection that developed from her regular encounters with her patrocinador.

Christian Groes-Green's study of sexuality and notions of femininity in Maputo showcases a similar story. Eighteen year old Maria had arrived in the capital at the age of fifteen:

At first she had lived with a cousin who took care of her while she attended secondary school. But her situation changed when she met an older Dutch man in a nightclub who soon became her lover. He decided to give her a monthly contribution so she could rent an apartment where they would be able to meet in privacy when he was in the country to do business. ... Besides her lover, she also had casual sexual relations with other men she met in the city's nightlife, mostly older men who catered for her and bought her gifts (Groes-Green 2011, 299).

According to Groes-Green, Maria did not want to be completely dependent on the Dutch lover and preferred to keep her options open in case "he turned abusive or ... decided no longer to support her" (ibid). Indeed, some young women acknowledged having multiple partners, each of whom met their different needs. As Nolwazi, a thirty-year-old woman from Johannesburg, explained:

Often girls have several partners: they have a boyfriend, someone they really love and enjoy sex with; they have a sugar daddy who has money and can provide them with beautiful stuff ... cell phones and air time [minutes of credit on phone cards] and also cash.

Young women are strategically engineering sexual relationships to achieve their goals and maximize their gains. In his study of sexuality among female university students in Dakar, Tshikala Biaya highlights two types of multiple-partner relationships: the ménage à trois, where a girl combines her regular boyfriend with a thiof', the local metaphor for sugar daddy, who provides money and gifts in exchange for sexual favours, which the girl uses for herself, her boyfriend, and her family; and the ménage à quatre, which is slightly more complicated as it also includes a teacher or administrator from the university who assists with

${ }^{7}$ Thiof is the name of the most prized and expensive fish in Senegal afforded only by the elites (see Nyamnjoh 2005). 
class work and administrative matters in exchange for occasional sexual favours (Biaya 2001; Nyamnjoh 2005).

In South Africa, too, young women in waithood engage in sexual relationships with multiple partners. When Mark Hunter asked Mrs. Buthelezi of Kwazulu Natal whether these young women saw themselves as prostitutes, she responded: "It's different. ... Here, at the township, the level of unemployment is high. The girl comes from Nongoma [in northern Kwazulu Natal] looking for work, she can't find work and she gets a boyfriend who will pay her rent, another to buy her food, another one who is going to give her money, and the other will help her with transport. (...) The situation forces her," Mrs. Buthelezi concluded (2010, 180-81).

Mobile phones and text messaging facilitate young women's management of multiple relationships (Bruijn et al 2009). Some have a mobile phone for each partner, often provided by the man himself, which they use to arrange meetings, as well as to avoid mix-ups in their communications with different partners. As a smart marketing tool, cell phone service providers offer free "please call me" messages that allow young women to communicate with their partners even when they have no airtime.

Sugar daddies are not a homogeneous group. "Super" sugar daddies can afford the most extravagant gifts; these are often members of government, parliamentarians, diplomats, top businessman, and wealthy foreigners. "Regular" sugar daddies are middle-class men with some resources to spare; they are mainly civil servants, middle range businessmen, university lecturers, teachers and the like. Most are married and have families. Their financial power, rather than their looks or sexual performance, guarantees their success with young women. The types of relationships that develop are also diverse, ranging from occasional sexual encounters with little affection to more regular companionship. Some "super" sugar daddies install their mistresses in a small apartment where they can meet regularly. Sharing a common space changes the dynamic of the relationship and the young woman's obligations toward her sugar daddy. Other relationships are less bound, offering young women more room to manoeuvre.

Sugar-daddy relationships are not exclusive. Many girls in sugar-daddy relationships also have a steady boyfriend, generally a young man their own age who is unable to provide the resources offered by older, more affluent men. The story of Samir, a young man I met in Tunis, 
illustrates some of the dilemmas that young men face. At twenty-eight, he was sad about losing his girlfriend of three years. The relationship started to deteriorate a year before when his girlfriend turned twenty-six and began mentioning that she wanted to get married. Warning him that she was not getting any younger, she urged him to try harder to find a job. While Samir was aware of the difficulties of their situation, all he could get were temporary freelance jobs. One day a couple of friends told him that they had seen his girlfriend with another man. When he confronted her, she admitted it and decided to leave him. "I later found out that her new lover was a forty-year-old man, married with two children, who had a good position in a private company. ... He had a very nice car and showered her with expensive gifts. ... How could I compete with that?" Samir concluded despondently.

In this case the couple broke up, but in a surprising number of instances the boyfriend remains in the relationship. In the absence of viable economic alternatives, an intergenerational sexual relationship complements the romantic relationship between two young people. The older man provides the young woman with the economic resources she needs, and she shares them with her boyfriend and often with her family. In this way, as Mark Hunter points out, a sugar daddy is seen as a secondary lover, because there is little expectation that the relationship will lead to marriage $(2010,191)$.

While some young women may try to hide their sugar-daddy relationships from their boyfriends, many are open about it; after all, it is hard to keep these relationships secret. As Coumba, a twenty-nine-yearold Senegalese woman, put it: "How can you hide the relationship? Your boyfriend will wonder where the money and the nice stuff are coming from, and you need to be able to explain." Boyfriends often resign themselves to the fact that they cannot compete with rich older men and end up accepting the situation and, indeed, benefiting from it.

\section{Sugarmamas, beach boys and toubabs}

"It is not just girls who go out with older rich people. ... Boys too, they have older women with whom they have sex and receive money, gifts, and other favours from.... Some hook up with older toubab [European]

\footnotetext{
${ }^{8}$ Various terms are used to describe these women; I have come across sugar-mommies, sugar-mothers, and sugar-aunties. I use sugar mamas because this was the term suggested by a group of young people with whom I discussed the issue.
} 
women," said Fatou, a twenty-five-year-old Senegalese woman. While it appears that young women more frequently engage in transactional sex, young men are no less preoccupied with the financial security, fashion and other gifts and protections that transactional sex may offer.

This dynamic is clear in the story of Abdoul, a twenty-eight-year-old man who lives in Tunis. When I interviewed Abdoul, he told me that he owed about TND 2,500 (US\$1,750) in university fees and had only one week to pay; otherwise he would not be allowed to continue the course. So, he said, "I have to go and see a couple of old ladies that I sleep with from time to time when I need money. ... One of them wants me to become her regular lover, but I don't want it, I prefer to visit her from time to time when I feel like it ... or, better, when I need money." Both of these women were in their forties and held well-paid, full-time jobs. One was married; the other, the one who wanted a more regular sexual relationship, was single.

Pap, a twenty-three-year-old Senegalese student, had an ongoing sexual relationship with an older woman he met a few times a week just for sex. He also had a copine (girlfriend). According to Pap, sex with the older woman was good, but it was just sex; the person he was really in love with was his girlfriend. Older women who engage in sexual relationships with young men are known in Senegal as diriyanke (Nyamnjoh 2005). Diriyankes are normally single or divorced women who have been successful in business and are in a position to reward younger men financially. They dress exquisitely in traditional boubous (local widesleeved robes) and wear lots of expensive jewellery. In general, diriyankes are sexually mature and reputed to be expert in the art of seduction (Nyamnjoh 2005). With the income from his sexual transactions with his diriyanke, Pap was able to alleviate his financial pressures and afford occasional gifts for his girlfriend.

Abdoul's and Pap's sugar mamas were both affluent local women, but Sulemane's sugar mamas are mainly toubab women, mostly European tourists. Sulemane, a twenty-seven-year-old Senegalese from Rufiske in the outskirts of Dakar, comes from a relatively poor family. His father is a tailor and his mother a housewife. He dropped out of school at the age of sixteen and worked as a street vendor until he discovered bodybuilding. He and his friends often do gymnastics on the beach in front of the corniche, the famous ocean drive in Dakar. With his virile physique, Sulemane has no trouble attracting the attention of foreign women who visit Senegal for what many youths call the "three Ss: sun, 
sea, and sex." Sulemane started engaging in transactional sex with older, white European women and became what locals call a côtéman ${ }^{9}$ (beach boy). Côtéman generally hang around hotels and beaches and offer sex to tourists, primarily women but also men, in exchange for money and gifts. A few lucky ones may be able to secure a plane ticket and a visa to visit their sugar mamas in Europe. It is easy to spot a beach boy, I was told, as they are well built with extremely athletic physiques. They normally have long dreadlocks, which they tie back with bandanas in colourful Rastafarian tones. Many wear baggy patchwork trousers of printed African cloth and jewellery made from beads and shells adorns their neck and wrists. This rather stereotypical description of beach boys as presented by the Senegalese I spoke with coincides with Emilie Venables's (2009) account of beach boys in Casamance, on the southern coast of Senegal.

The development and flourishing of sex tourism for Europeans in Senegal and neighbouring Gambia has been well documented (Nyanzi et al 2005; De Jong 2007; Venables 2009; Chant and Evans 2010). Although beach boys are often seen in a negative light and connected with sexual promiscuity and trickery, some scholars argue that this is merely an unconventional way to earn a livelihood. Beach boys seem proud of what they do and see themselves as providing tourists with a commodity they are looking for (Venables 2009). Indeed, while they might be seen as simply selling sex, many beach boys develop skills that enable them to operate in the tourist environment. Many become knowledgeable guides, sell artefacts and African jewellery, or learn how to play drums (djembes) and improvise music sessions for their customers. Registered guides formally employed in the tourism industry tend to dislike beach boys and see them as competitors (Venables 2009).

Moussa, a thirty-one-year-old dreadlocked drum player, said that "the women come here alone. They hit on you, and you go with it. ... They like men with rastas [Rastafarian-style dreadlocks] who play the djembes. It's part of the ambiance." Being a beach boy is "a question of survival. Life is hard. If I didn't have these women, I'd be struggling". ${ }^{10}$ Moussa said that he has received countless gifts from European women visiting Senegal, including CDs, USB drives, a guitar, an MP3 player

\footnotetext{
${ }^{9}$ The word côtéman is taken from the French word côté, meaning "side," because they are always at the side of tourists (De Jong 2007; Venables 2009).

${ }^{10}$ Moussa's account is presented in Anne Look, "Senegal Draws Tourists with Sun, Sea and Sex: Female Sex Tourism in Senegal Attracts Women Who Will Pay for Romance," Global Post, April 2010, available on the www.globalpost.com website.
} 
and a DVD player. "I don't ask for money. ... We go out. They pay for everything. We have sex. Before they leave, they give me a bit of cash to help me out." Both Sulemane and Moussa hope that one day they will be lucky enough to meet a woman who will take them to Europe. Moussa says longingly, "I haven't met her yet ... the woman who will get me a visa and a plane ticket out of here."

Lucas, a thirty-two-year-old Mozambican, travelled to Sweden with his sugar mama and lived there for about a year before returning home. They met in Mozambique when the Swedish woman, twenty-five years his senior, was working there for an international company. What started with occasional sexual encounters turned into a more stable relationship. Lucas moved into her apartment, and six months later they moved to Stockholm. "Life in that country was very hard for me because I didn't speak the language and culturally it was very different. ... It was very, very cold in the winter. ... She loved me and treated me well, but I completely depended on her for everything. ... In the end it wasn't working for me. ... Deep down I was not really in love with her, and I missed my country.... One day I got the courage to tell her that I wanted to come back home." While these relationships may occasionally offer the possibility of moving to Europe, they are not seen as a strategy for international migration.

Transactional sex between young Senegalese women and toubab men also occurs in Dakar. Senegalese girls openly display affection toward older, gray-haired, white men in expensive restaurants, luxury hotels, and trendy nightclubs. Some newspapers and magazines carry personal ads that say things like: "Beautiful young Senegalese female looks for white European man for romantic relationship." These relationships vary from prostitution to the sugar-daddy type, depending on the reciprocal obligations involved.

\section{Virginity, hymenoplasty and marriage}

Some young women in Africa struggle with long-established social and religious mores requiring brides to be virgins. Samir, whose girlfriend left him for a sugar daddy, pointed out some of the issues related to premarital intercourse. He was very much in love with his girlfriend, but "during the three years we were together I never touched her [made love to her].... I respected her because I wanted to marry her." Although 
he believed that women should have the freedom to control their own bodies, he did not want his girlfriend to be humiliated by others. He wanted to preserve her dignity and her family's honour by making sure she was virgin at the time of their marriage. He believed that was the greatest expression of his love for her. Women's virginity is still a major issue in Tunisia, and there is overwhelming social pressure against premarital sexual intercourse. Despite all the appearances of modernity, female virginity at marriage is a prerequisite for many families across a varied social strata.

Today, however, the average age of women's first sexual experience is declining, and the proportion of females engaging in premarital intercourse is increasing (Foster 2002). As in most times of rapid social change, there is a disturbing dissonance between sexual realities and societal expectations. Due to the economic crisis and lack of employment opportunities for youth, the average age at first marriage for Tunisian women is now twenty-eight. Young unemployed men are unable to acquire the resources to marry and establish families of their own. The tensions between socioeconomic reality and social and religious mores place significant pressure on many young women - both those who choose to abstain from sexual activity and those who engage in it.

Zeinab, a twenty-six-year-old Tunisian woman, stated clearly that this was a major problem for women, because "our partners want to have sex and we have to say no, and sometimes a girl may lose a boyfriend because of that, as he will look for a girl who gives him sex." Other young women said that men want to have sex but then don't want to marry a girl who is not a virgin. They were very critical of the men's hypocrisy. Abdeljelil, a twenty-eight-year-old man, emphasized that young men want to have sexual experiences with their girlfriends before marriage, especially because now they have to wait too long to marry. At the same time, if the girls are not virgins, the men often refuse to marry them, mainly because of family, religion and other social pressures. As Abdeljelil points out:

It is a contradiction experienced by Tunisian young men. ... True, there are girls to marry and girls to play with ... but at the end of the day every woman is somebody's daughter and somebody's sister. ... Also you want to share that experience with your girlfriend ... and the girls also want to have that experience too. ... It is becoming more difficult for young women to abstain from sex until they get married. ... We want to enjoy our youth and our freedom. 
Pressure to preserve their virginity affects young women from all social strata. For example, young women who leave their hometown for the big cities to pursue a university education are often cast under suspicion. Many are asked by the groom's family to obtain a certificate of virginity issued by a doctor. Even when the potential in-laws do not demand a certificate, the young woman's own family may offer to provide one in order to dispel any possible doubts. Many young women try to find a compromise between their desire to be sexually active and societal pressure to remain virgins. Some opt to refrain from sexual acts that can rupture the hymen.

Twenty-four-year-old Aicha explained, "We have to try and be intimate with our partners in ways that preserve our virginity. ... The positive side of that is that we have to be creative and explore other forms of sexual intimacy and pleasure without vaginal penetration." But some young women I spoke with said that they still felt curious and somewhat unsatisfied because they had not fully experienced sex. As Zeinab stated, "The forbidden fruit is always the most desirable. ... No matter how pleasurable the other things you do, you always wonder how it would feel like to do it like everybody else does. ... After all, vaginal penetration is how most people have sex, so why should we be different?"

Despite their efforts to abstain, more and more young women do not keep their virginity until marriage. "The majority of the girls that I know have already had sexual intercourse," asserted Jamila, a twentytwo-year-old Tunisian woman. As Aicha pointed out, "Our society is full of inconsistencies. ... Women have rights, they can smoke, they can wear tight jeans, short skirts and show their bellies. ... But they can't lose their virginity before marriage."

One of the consequences of the increase in premarital sex is the escalation in requests for virginity certificates and the demand for hymen-repair surgery. In Tunisia, according to Angel Foster, a growing number of gynaecologists provide hymen restoration in private clinics, even though the procedure is officially banned. One physician stated: "Though I think it is a form of deception, I reconstruct women's hymens. I don't believe that a girl's life should be ruined because of an adventure. Tunisian mores are conservative and there is a double standard, so I don't feel any guilt about my work" (Foster 2002, 104-5). According to Jamila, "the surgical operations are very popular. ... Everybody knows about the clinics but nobody says anything. ... It's like, do it but don't discuss it openly." Young women have recourse to surgery to avoid shame 
and embarrassment for their families. Having sugar daddies who can cover the costs makes them free to enjoy sexual experiences with both their sugar daddies and their boyfriends. Hymenoplasty is considered a relatively minor surgical procedure, so it has become a convenient solution for many women who can afford it.

A 2010 documentary entitled National Hymen: The Malaise in Islam by Belgian-Tunisian director Jamel Mokni has generated considerable debate in Tunisia. The film showcases interviews with various groups of people in Tunisia about women's virginity and premarital sex. Unlike previous documentaries on sensitive issues, the director and the interviewees agreed not to have their faces blurred. The hour-long film explores how Tunisian mores have changed over time and discusses the rise in the average age at marriage as well as the growth in the demand for hymen surgery. The film highlights society's double standard. Women are rarely forgiven for losing their virginity and are held responsible for upholding their family's honour, while the men to whom they lost their virginity are never responsible for ruining a family's reputation. The documentary was banned from the Carthage Film Festival in October 2010 on the grounds of being offensive to Muslims. Clandestine screenings in the country, however, increased awareness and stimulated discussion. In a television interview Mokni mentioned that even in Belgium and France the film faced strong opposition from Muslim communities. This topic is a delicate one for Muslims, especially men. As Mokni pointed out, the virginity of women instils a sense of masculinity and power in men that they are afraid of losing. ${ }^{11}$

In Senegal widely held Muslim mores require young women to preserve their virginity for marriage, but people appear more tolerant of premarital sex, or at least turn a blind eye. Young people I met in Dakar believe that the majority of girls engage in sex before marriage. "Although the norm is still there nobody really respects it. ... And nobody talks about it either. ... We all pretend that everything is okay, even on the wedding night," said Bobo, a twenty-one-year-old woman from Kaolack.

According to Anouka van Eerdewijk, who studied premarital sexuality in Dakar, on the wedding night families still claim the virginity of the bride to keep their dignity, even though nobody has any illusions about most brides. False shows of blood have been used for many years;

${ }^{11}$ Jemel Mokni was interviewed by TV 5 Monde on 11 March 2011. The interview is available on http://www.youtube.com/watch?v=Gf5fgzplZN4. 
everyone knows, but no one talks about it. The ritual of the wedding night, known as the jéballe, in which a woman has to prove that she is a virgin, is still practised. However, one almost never hears of a wedding being called off because the girl was not a virgin. Following the ritual tradition, the next morning the aunts of the bride visit the couple's room and come out singing that all is in order and the marriage has been consummated according to tradition. Indeed, people do not dissociate themselves openly from this practice because "the bride and groom as well as the bride's relatives have a vested interested in claiming virginity" (van Eerdewijk 2009, 13).

In Senegal, as in Tunisia, there is a discrepancy between traditional and religious mores regarding young women's premarital sexuality and the freedom they enjoy today, especially in urban centres. Abdoulaye Diop emphasizes:

People make reference to symbols that pretend to refer to the same meanings as before. But they are either trickery and deception, like the nuptial sheet, or purely formal, like the prix de la virginité [price of virginity]. They do not carry any real meaning any more apart from expressing an effort to appear to respect a past that, in fact, in many ways substantially differs from the present (Diop 1985, 123).

The young women whom I interviewed in Dakar never discussed their particular situations but addressed the issue in general terms, making statements such as: "today girls in Senegal have more control over their sexuality." While they continue to publicly acknowledge the social norm requiring female virginity, they are critical of the ritual of the wedding night, which their families seem to insist on maintaining. Young people's desire for sexual autonomy and their engagement in transactional sex have become part of local constructions of masculinity and femininity in a context of widespread unemployment and scarcity.

\section{Refashioning masculinity and femininity}

These new geographies of sex among young people are challenging hegemonic notions of masculinity and femininity. African masculinities based on men's position as providers are being undermined by rising unemployment, as men are no longer able to fulfil conventional social expectations (Arnfred 2004). Although today many men in their twenties are unable to get a stable job, build or rent a home, marry and establish a family, many remain deeply influenced by society's ideal of men as 
breadwinners. Indeed, the young men I spoke with often felt inadequate and described their predicament as "not being man enough" or being "a worthless man." This sentiment was related to the way society regarded them, as well as to their families' and girlfriends' complaints that they do not provide financial support (Groes-Green 2009). The power that impoverished, unemployed young men have over women is fragile and unstable.

In the absence of work, status, and money, "male identity and self-esteem become increasingly linked to sexuality and sexual manifestations" (Silberschmidt 2004, 234). Young men reassert their masculinity through power that derives from the body (Groes-Green 2009), constructing their masculinity on the basis of sexual conquests and sexual performance (Arnfred 2004). Indeed, because unemployed young men in waithood lack the economic advantage over women that employed men have, sexual power is the only tool left to them. Young men improve their physique and bodily performance to attract older women and foreign tourists; boyfriends try to maintain their relationships with their girlfriends by being better in bed than sugar daddies. Young men's preoccupation with their bodies and satisfying their female partners illustrates a search for power and authority over women in the sexual arena (Groes-Green 2009).

Similarly, some men resort to violence and coercion to express their power and assert control over their girlfriends or other women. Young men feel diminished by their inability to help financially and to offer gifts to the women they are intimate with, seeing their poverty as an insult to their manhood (Groes-Green 2009). While not all violence against women can be attributed to the disempowerment of men, many observers have pointed out links between male violence against women and men's marginalization (Bourgois 1995; Silberschmidt 1999; Morrell 2003; Barker 2005; Dunkle et al 2007). Massive male unemployment and the high incidence of rape go together in South Africa and can be seen as evidence of the socioeconomic basis of violence against women. Mark Hunter points out that the increase in gang rape in South Africa (known as jack-rolling) appears to be consistent with an unmooring of gender norms at a time when many men are unable to find work and marry $(2010,173) .^{12}$

\footnotetext{
${ }^{12}$ Mark Hunter also stresses that women's increasing employment and the erosion of the "patriarchal bargain" centered on marriage have made male-female relations more contested, and gang rape is linked to these contestations in complex ways $(2010,173)$.
} 
Femininity has been constructed through passivity and subordination to men. Some researchers emphasize the emergence of notions of female agency and power, including ideas of respectability and female independence (Haram 2005; Spronk 2007). Men have often been depicted as taking the initiative in sexual matters, inviting a woman to have sex or to become his partner, while women are supposed to be passive (Loforte 2000; Bagnol and Chamo 2004; Tamale 2011).

Scholars have contested these views about women's complete powerlessness in sexual matters, however (Groes-Green 2011). The stories of young women engaged in multiple relationships with sugar daddies and boyfriends suggest that women can actively initiate and control these sexual relationships. Some appear to have the upper hand over their sexual partners as they navigate among men, put their boyfriends in a position of either accepting the sugar daddy or leaving and carve their sexual and financial independence by avoiding being controlled by any one man. Maria's refusal to become solely dependent on her Dutch lover and her decision to take on other sugar daddies illustrates the point. Women also make sure that they find sexual satisfaction; a boyfriend's desire to continue the relationship ensures that he pays attention to the woman's pleasure.

Women are increasingly becoming agents in their own sexual lives in places across the global South. Jennifer Gregg's work with young women in Recife, Brazil, demonstrates that women try to guarantee their relative independence by ensuring that the material benefit of sexual engagements does not come from a single man who could exercise control over them, but from a changing and flexible network of men, none of whom is able to wield power over them (Gregg 2003). The agency of young women in these instances is often perceived in negative terms, described as "milking," "sucking," or "putting men in the bottle"13 (Hawkins et al 2009). As Christian Groes-Green (2011) asserts, these expressions position young women as powerful agents who extract value and money from men. Men, on the other hand, are seen as victims who are easily manipulated.

These young women do not conceive of themselves as passive or coerced victims in their relationships with men. Rather, they are involved

13 "Milking" and "sucking" relate to the young women's ability to get whatever they want from these men; "putting men in the bottle" means exercising control over them. These terms often portray the young women as taking advantage of the men, but at the same time they present an image of these men as being easily manipulated or manipulable by the young women. 
in a continuing process of defining their social and sexual identities and making choices about the activities they engage in and the risks they run. Transactional sex is seen as a strategy by which they are able to reverse the existing balance of gender and power relations and gain access to the material goods and lifestyle that symbolize modernity and success (Hawkins et al 2009).

Young women's relationships with sugar daddies can be understood as part of a process through which new ideals of female agency and independence are being constructed across Africa, especially in urban settings (Cole 2004 Haram 2005; Silberschmidt and Rasch 2001). Young women's drive to control their sexuality, become independent and achieve relative economic stability challenges conventional notions of ideal womanhood centered on female virginity, arranged marriage and obligations to the extended family (Tersbøl 2005; Mills and Ssewakiryanga 2005; Spronk 2007; Groes-Green 2011). These shifts demonstrate the contingent and fluid nature of masculinity and femininity in dynamic social, economic and cultural settings.

\section{Changing intimate relations}

Sugar-daddy relationships are found in developed countries as well as in the global South. In the United States, in part as a result of the deepening economic crisis, sugar daddies are becoming attractive to young women struggling with college tuition or inadequate employment. A number of websites link wealthy men with young women for transactional sex. A New York Times article mentions that people using the sites are "not searching for longtime soul mates; they want no-stringsattached 'arrangements' that trade in society's most valued currencies: wealth, youth and beauty." ${ }^{14}$ A Huffington Post article describes young women who resort to sugar daddies to make money and establish contacts with well-placed men who can help their careers. They may be paid US\$1,000-3,000 a month, in addition to expensive gifts and travel. Some sugar-daddy websites target needy students, paying to have their ads pop up whenever someone types in "student loan," "tuition help" or "college support." ${ }^{15}$ Parties where affluent men pay to meet attractive

${ }_{14}$ Ruth Pidawer, "Keeping Up with Being Kept," New York Times, 10 April 2009, available on the www.nytimes.com website.

15 Amanda Fairbanks, "Seeking Arrangement: College Students Using 'Sugar Daddies' To Pay Off Loan Debt," Huffington Post, 31 July 2011, available on the www. huffingtonpost.com website. 
younger women are held in the United States and the UK. ${ }^{16}$ In a time of economic recession young people come to regard their bodies as livelihood assets (Chant and Evans 2010).

At the same time it is important to recognize that young people are exercising their agency within these complex sexual relationships rather than simply being victimized by the exchange. Investing in their physique and sexual prowess, beach boys in Senegal create an image of exotic Africa that features not only sun, sea and palm trees but also sculpted black bodies with dreadlocked hair, wearing colourful fabrics and beads, playing drums, and sipping coconut drinks. The young men create and purvey this vision of the erotic "other" that many female European tourists desire. Similarly, young women exercise control in their relationships with sugar daddies. By engaging in relationships with multiple partners, they avoid being dominated by or fully dependent on any one partner. Despite their money and social status, sugar daddies can be manipulated. The delay in marriage offers young women a vast array of options and freedoms that they would not have if they were married.

It is important to remember that these sexual relationships can be lethal. Sugar daddies are often reluctant to use condoms, and some young women may still find it difficult to demand that they do so. Although some young women claim that they insist that their sexual partners use condoms, UNAIDS statistics indicate that the risk of HIV transmission remains high. In Mozambique, for example, young women account for 60 per cent of all new infections (UNAIDS 2006). The Mozambican Ministry of Health estimated in 2010 that young females were the group most vulnerable to HIV infection, with a prevalence rate of 23 per cent in Maputo. HIV/AIDS awareness organizations often fail to appeal to youth. For example, the LoveLife AIDS intervention programme for youth in South Africa became caught up in ABC advocacy (Abstinence, Being faithful, and Condom use) and was unable to address the complexity of young people's sexual experiences and desires.

The lack of jobs, inability to find housing and high cost of marriage rituals, coupled with not finding a suitable spouse or a preference for remaining single, lead many young people to postpone marriage, sometimes indefinitely (Singerman 2007). Boyfriends and girlfriends often have to accept the presence of third parties in their relationship, changing the nature of intimacy and sexual relationships. What happens to

\footnotetext{
${ }^{16}$ Craig Dawson, "American-style Sugar Daddy Parties Are Coming to the UK," NewsBrat, BBC Radio 1, available on the www.bbc.co/uk website.
} 
the emotional dimension of romantic relationships when one party is subsidized by a sugar daddy or sugar mama? How do young men and women adjust to these complex sexual and financial exchanges? Traditional courtship was based on exclusivity, with men feeling possessive of their girlfriends and with lots of jealousy between partners. How are those feelings negotiated and managed in these intricate, multiple-partner relationships? We must also wonder whether young married couples with meagre resources engage in transactional sex in order to lead a more comfortable life.

These are some important questions that merit further multidisciplinary research and analysis. An interrogation of existing epistemological frameworks and conceptual paradigms might shed new light and improve current understandings of the processes through which young Africans are fashioning new forms of masculinity and femininity and challenging traditional notions of female and male sexuality in their societies.

\section{References}

African Union. 2006. Youth charter. Addis-Ababa: African Union.

Arnfred, Signe. 2004. "Re-thinking sexualities in Africa: Introduction". In Rethinking sexualities in Africa, edited by Signe Arnfred, 1-27. Uppsala: Nordic Africa Institute.

Bagnol, Brigitte, and Ernesto Chamo. 2003. "Titios e quatorzinhas: Pesquisa exploratoria de sugar daddies na Zambezia”. Report to Department for International Development and PMG Mozambique.

Biaya, Tshikala. 2001. "Les Plaisirs de la Ville: Masculinite, Sexualite et Feminite a Dakar (1997-2000)”. African Studies Review 44 (2):71-85.

Bhana, Deevia, Robert Morrell, Jeffm Hearn and Relebohile Moletsane. 2007. "Power and identity: An introduction to sexualities in Southern Africa". Sexualities 10(2):131-39.

Bourgois, Philippe. 1995. In search of respect: Selling crack in El Barrio. Cambridge: Cambridge University Press.

Bruijn Mirjam, Francis Nyamnjoh and Inge Brinkman, eds. 2009. Mobile phones: The new talking drums of everyday Africa. Bamenda, Cameroon: Langaa.

Castle, S., \& M. Konate. 1999. "The Context and Consequences of Economic Transactions Associated with Sexual Relations among Malian Adolescents." Paper presented at the Third African Population Conference, Durban, South Africa, 6-10 December.

Chant, Sylvia, \& Alice Evans. 2010. "Looking for the One(s): Young Love and Urban Poverty in The Gambia”. Environment \& Urbanization 22 (2):353-69.

Chatterji, Minky, Nancy Murray, David London, and Philip Anglewicz. 2004. "The actors influencing transactional sex among young men and women in 12 sub-Saharan African countries." Washington DC: Policy Project. 
Cole, J. 2004. "Fresh contact in Tamatave: Sex, money and intergenerational transformation." American Ethnologist 31 (4):573-88.

De Jong, Lou. 2007. "We plakken als vliegen, maar steken niet als muggen": Ontmoetingen tussen coteman en toeristen in Senegal ["We stick like flies, but do not sting like mosquitoes": Encounters between coteman and tourists in Senegal]. Amsterdam: Aksant.

Dhillon, Navtej, and Tarik Yousef, eds.. 2009. Generation in waiting: The unfulfilled promise of young people in the Middle East. Washington, DC: Brookings Institution Press.

Diop, Abdoulaye. 1985. La famille Wolof. Paris: Karthala.

Dunkle, Kristin, Rachel Jewkes, Mzikazi Nduna, Jonathan Levin, Yandisa Sikweyiyam and Mary Koss. 2007. "Transactional sex with casual and main partners among young South African men in the rural Eastern Cape: Prevalence, predictors and associations with gender-based violence". Social Science and Medicine 65(6):1235-48.

Foster, Angel. 2002. "Young women's sexuality in Tunisia: The health consequences of misinformation among university students". In Everyday life in the Muslim Middle East, edited by Evelyn A. Early and Donna Lee Bowen. Bloomington: Indiana University Press.

Gregg, Jennifer. 2003. Virtually virgins: Sexual strategies and cervical cancer in Recife, Brazil. Palo Alto: Stanford University Press.

Groes-Green, Christian. 2011. "The Bling scandal: Transforming young femininities in Mozambique”. Young 19(3):291-312.

Groes-Green, Christian. 2009. "Hegemonic and subordinated masculinities: Class, violence and sexual performance among young Mozambican men”. Nordic Journal of African Studies 18(4):286-304.

Haram, Liv. 2005. "Eyes have no curtains": The moral economy of secrecy in managing love affairs among adolescents in Northern Tanzania in the time of AIDS'. Africa Today 51(4): 57-73.

Hawkins, Kirstan, Neil Price and Fatima Mussá. 2009. "Milking the cow: Young women's construction of identity and risk in age-disparate transactional sexual relationships in Maputo, Mozambique". Global Public Health 4(2):169-82.

Honwana, Alcinda. 2012. The Time of Youth: Work, Politics and Social Change in Africa. Sterling VA: Kumarian Press.

Honwana, Alcinda. 2012 "Women's Rights in Tunisia”. Paper prepared for the Social Science Research Council. Unpublished

Honwana, Alcinda and Filip De Boeck. 2005. Markers and Breakers: Children and Youth in Postcolonial Africa. Oxford, Trenton and Dakar: James Currey, Africa World Presss and Codesria.

Hunter, Mark. 2002. "The materiality of everyday sex: Thinking beyond "prostitution." African Studies 61 (1):99 120.

Hunter, Mark. 2007. "The changing political economy of sex in South Africa: The significance of unemployment and inequalities to the scale of the AIDS pandemic." Social Science and Medicine 64 (3):689 700.

Hunter, Mark. 2010. Love in the time of AIDS: Inequality, gender, and rights in South Africa. Bloomington: Indiana University Press.

Karlyn, Andrew. 2006. "Intimacy revealed: Sexual experimentation and the construction of risk among young people in Mozambique". Culture, Health \& Sexuality 7 (3):279-92. 
Kaufman, Carol, and Stravos Stavrou. 2004. "Bus fare please: The economics of sex and gifts among young people in urban South Africa." Culture, Health \& Sexuality 6 (5):377 91.

Leclerc-Madlala, Suzanne. 2003. "Transactional sex and the pursuit of modernity." Social Dynamics 29 (2):213 33.

Loforte, Ana. 2000. Gênero e Poder entre os Tsonga de Moçambique. Maputo: Promédia.

Longfield, Kim. 2004. "Rich fools, spare tyres and boyfriends: Partner categories, relationship dynamics and Ivorian women's risk for STIs and HIV". Culture Health \& Sexuality 6 (6):483-500.

Longfield, Kim, A. Glick, M. Waithaka, and J. Berman. 2004. "Relationships between older men and younger women: Implications for STIs/HIV in Kenya." Studies of Family Planning 34 (2):124-34.

Luke, Nancy. 2005. "Investigating exchange in sexual relationships in sub-Saharan Africa using survey data." In Sex without consent: Young people in developing countries, edited by Shireen J. Jejeebhoy, Iqbal Shah, and Shyam Thapa, 10524. London: Zed Books.

Luke, Nancy, and Kathleen Kurz. 2002. "Cross-generational and transactional sex relations in sub-Saharan Africa: Prevalence of behaviour and implications for negotiating safer sex practices." International Center for Research on Women.

Machel, Josina. 2001. "Unsafe sexual behaviour among schoolgirls in Mozambique: A matter of gender and class." Reproductive Health Matters 9 (17):82-90.

Maira, Sunaina, and Elisabeth Soep, eds. 2005. Youthscapes: The popular, the national, the global. Philadelphia: University of Pennsylvania Press.

Masvawure, Tsitsi. 2010. "I just need to be flashy on campus: Female students and transactional sex at a university in Zimbabwe." Culture, Health \& Sexuality 12 (8):85770.

Mills, David and Richard Ssewakiryanga. 2005. "No Romance without Finance: Commodities, Masculinities \& Relationships amongst Kampalan Students." In Readings in Gender in Africa, edited by Andrea Cornwall, 90-94. Oxford: James Currey.

Morrell, Robert. 2003. "Silence, sexuality and HIV/AIDS in South African schools." Australian Educational Researcher, vol. 30 (1):41-62.

Njue, Carolyne, Helen Voeten, and Remes Pieter. 2011. "Porn video shows, local brew, and transactional sex: HIV risk among youth in Kisumu, Kenya." BMC Public Health 11:635.

Nyamujoh, Francis. 2005. "Fishing in troubled waters: Disquetes and thiofs in Dakar". Africa 75 (3):296-324.

Nyanzi, Stella, Ousman Rosenberg-Jallow, Ousman Bah, and Susan Nyanzi. 2005. "Bumsters, big black organs and old white gold: Embodied racial myths in sexual relationships of Gambian beach boys". Culture, Health and Sexuality 7 (6): 557-69.

Pettifor, Audrey, Michael Hudgens, Brooke Levandowski, Helen Rees, and Myron Cohen. 2007. "Highly efficient HIV transmission to young women in South Africa." AIDS 21 (7):861-65.

Poulin, Michelle. 2007. "Sex, money and premarital partnerships in southern Malawi”. Social Science and Medicine 65 (11):2383-93.

Reddy, Shakila, and Máiréad Dunne. 2007. "Risking it: Young heterosexual femininities in the South African context of HIV/AIDS". Sexualities 10 (2):159-72. 
Silberschmidt, Margrethe 2005. "Poverty, male disempowerment, and male sexuality: Rethinking men and masculinities in rural and urban East Africa." In African masculinities, edited by Lahouzine Ouzgane and Robert Morrell, 189-203. New York: Palgrave Macmillan.

Silberschmidt, Margrethe, and Vibeke Rasch. 2001. "Adolescent girls, illegal abortions and 'sugar-daddies' in Dar es Salaam: Vulnerable victims and active social agents". Social Science \& Medicine 52 (12):1815-26.

Spronk, Rachel. 2007. "Beyond pain, towards pleasure in the study of sexuality in Africa”. Sexuality in Africa Magazine 4 (3):3-6.

Singerman, Diane. 2007. "The Economic imperatives of marriage: Emerging practices and identities among youth in the Middle East". Working Paper 6. Wolfensohn Centre for Development/Dubai School of Development. Dubai.

Standing, Hilary. 1992. "AIDS: Conceptual and methodological issues in researching sexual behaviour in sub-Saharan Africa." Social Science and Medicine 34 (5):475-83.

Tamale, Sylvia (ed). 2011. African Sexualities: A Reader. Oxford: Pambazuka Press.

Tersbøl, Britt. 2005. At a Loss in the Land of the Brave: A Study of Sexual Relationships in the Context of HIV/AIDS and Poverty in Namibia. Ph.D. Thesis. Institute of Public Health, University of Copenhagen.

Thomas, Lynn, and Jennifer Cole. 2009. “Thinking through love in Africa”. In Love in Africa, edited by Lynn Thomas and Jennifer Cole, 130. Chicago: University of Chicago Press.

van Eerdewijk, Anouka. 2009. "Silence, pleasure and agency: Sexuality of unmarried girls in Dakar, Senegal". Contemporary Islam 3:7-24.

United Nations. 2007. World youth report 2007: Young people's transition to adulthood: progress and challenges. New York: United Nations.

Venables, Emilie. 2009. "If you give me some sexing, I might talk to you": Researching the Senegalese beach-boys "at my side". Anthropology Matters 1(11):1-11.

World Bank. 2007. World development report: Development and the next generation. Washington DC: World Bank. 


\section{LISTENING AND ARCHIVING MIGRANT VOICES: HOW IT ALL BEGAN}

\section{Alessandro Triulzi}

The Consul banged on the table and said 'If you have got no passport you're officially dead': But we are still alive, my dear, but we are still alive.

W.H.Auden. 1973. "Refugee Blues", Collected Shorter Poems 1930-1944, London, Faber \& Faber: 256.

As ECAS 5 opens in Lisbon, I want to share a series of reflections derived from a collective project I started a few years ago to record voices and memories of African migrants and asylum-seekers in Italy. ${ }^{1}$ Doing fieldwork among African migrants near home was a new start for me as I used to drawing most of my research data and source materials from Ethiopia, in particular western Ethiopia, from people traditionally straddling the Ethio-Sudanese frontier facing the Blue Nile (James 2002). For decades I tried to handle the intricacies of Ethiopia's imperial periphery and of its peoples' often silenced voices, till I gradually became involved with migratory flows in my own country and started collecting memories and testimonies from African migrants, mainly from the Horn, who were living in or passing through Italy. Borders and peripheries, I soon learned, produce nomadic voices and silences not just in Africa but in the Global North which often go beyond the very limits and frontiers of humanity.

Collecting and sharing individual and group narratives involving migrants and asylum-seekers in the very act of collecting meant revisiting my past research at the Ethiopian 'frontier' (Triulzi 1988) and stimulated a participatory process of joint research and advocacy that led in time to the creation of a multi-media Archive of Migrant Memories. ${ }^{2}$ The archive is designed to empower the voice and status of recently arrived immigrants in Italian society and stimulate their agency

1 This chapter is a revised version of a paper originally written for the colloquium "Studying Youth Migration: towards a research agenda", organized by the Human Sciences Research Council (HSRC) and Wits Forced Migration Programm in Johannesburg in February 2007.

2 The Archive was officially released in December 2011 (www.archiviomemoriemigranti.net). 
and creativity in coping with the many-folded 'enigmas' and iniquities in the country of arrival. Collecting testimonies of African migrants at the end of long and often traumatic journeys over sands and waters has meant departing from well-trodden paths of Africanist research and fieldwork (Triulzi and McKenzie, in print). In the last few years I asked myself at times whether this departure from academia and my original field was still part of African Studies. I want to argue here in favour of it, and I believe ECAS is the proper place to assess its reasons and limits within African Studies today.

\section{Reversing sail}

As a historian, I am convinced of the urgency and importance of recording migrants' itinerant voices and memories, so that the inner world of feelings and representations of present-day people moving in and out of Africa can be better appraised and contextualised within our societies. I also believe that Migrant and Refugee Studies, which have attracted much scholarly and government attention in the recent past, have not been advanced by the so-called humanitarian or security approach, nor by the 'ostrich-like detachment' that traditionally separated African Studies from "African migration ... and the condition of the African diaspora in Europe" (Zack-Williams 1995: 351). For a better understanding of the plight of African migrants, we have to investigate the global phenomenon of which they are part. We also need to know a lot more about the context of origin and destination, and further investigate how 'travelling cultures' meet and react to one another, as well as the unfolding dramas and success stories which affect the migrants' coming and living or surviving among us. I strongly believe that accounts and representations of the migrants' coming and settling, or simply squatting, should be recorded and retained not only for future reference but also for the memory of the groups and families on behalf of whom the migrants decide to leave their homes and move to another area or country.

As an Africanist, I must confess that globalized migratory flows raise a series of issues that $\mathrm{I}$, for one, have not been trained to cope with, as external migrations extend and cross the traditional borders of the African continent and its disciplines as we have intended and taught them until now. Yet I believe that today's Africanists are called 
in, and should be motivated, in exploring the 'out of Africa' process that has shaped the continent's peoples and their plight in history (Gomez 2005). In spite of the fact that Africans have always been 'on the move' (Amin 1995, Apokpari 1999), I think it is fair to say that the first generation of Africanists to which I belong was trained to confront the history of states, polities or societies as self-contained units of analysis - 'top down' or par-le-bas - investigating local agency vis-à-vis internal or external forms of autocracy or domination, but always focusing on peoples and societies of Africa and in Africa. It is not just sociologists or anthropologists but historians as well, who often maintain a 'sedentarist analytical bias' in their reading of the global migratory process (Malkki 1995: 508), as they appear to concern themselves more with the growth or decline of states, localities or institutions rather than with peoples' movements and migrations. In my view African Studies have yet to fully explore the trans-local, trans-national and trans-spatial horizons that were at the centre of ECAS 3 held in Leipzig in 2009. In the light of the present waves of population movements, it is high time that we reverse sail and that migrations and migrants, even when they go out of Africa, become part of our Africanist, not just humanitarian or security concerns.

The acceleration of trans-national migratory waves in the global world we live in started in the mid-1990s, when it was estimated that some 300 million 'Africans' lived worldwide, compared with 540 million residents in Africa (van der Veer 1995) By the end of that decade social scientists, planners and bureaucrats who dealt with these issues proposed solutions and remedies basically intended to control or reduce transnational mobility. Most of these remedies have gone in the direction of applying more control, restrictions and security on transnational mobility, which inevitably involved more abuse of civil rights and a general closing down of state frontiers and citizenry (Klepp 2010). Today the migratory world is much talked about and debated - both in European and African societies - and is acted upon and researched by endless cohorts of scholars, government agencies, NGOs and international experts. Yet I feel historians of Africa have been reluctant or unable so far to involve themselves in the study of trans-national movements of peoples outside the African continent, with the notable exception of the Atlantic slave trade and, more recently the Indian Ocean (Mohan and Zack Williams 2002; Kaarsholm and Sheriff 2012). Even internal migrations and displacements of peoples 
have been little researched in historical terms, and cultural or literary studies of trans-locality (also called Postcolonial Studies) far outweigh historical research on mobility, migrations and trans-nationalism in Africa. ${ }^{3}$ African history has been rather more successful in studying well-contained units through time than open-ended movements of peoples and ideas and their inter-relationship with moving spaces, especially when the moving involved the outside.

\section{Border crossing}

There are several reasons that, in my opinion, justify a more active involvement of African and Africanist social scientists in the global migratory issue, and make our discussions at ECAS conferences relevant to our respective studies. First, I believe that today's African internal and external migrations are part and parcel of African history, and that national histories of African communities (as well as their growth, rate and quality of development and the prevalence of peace or conflict) can no longer be understood or explained without including trans-national movements and flows of people, money, goods and ideas (Akyeampong 2000, Byfield 2000, Patterson and Kelley 2000). I also believe that the present migrations to (and through) the Mediterranean, the Middle East and Southern Europe are the result not just of desperate 'exit options' by people who have no other way of coping with the pressures of the present, but are increasingly the result of rational decisions by people who simply decide they want to broaden their outreach and range of options in life. These 'new' migrants are embedded into social, economic and kinship networks that are of extreme importance in sustaining and attracting migratory waves (Grillo 2000). Ever since the Arab revolts of winter and spring 20102011 along the Mediterranean coast, the right to more mature forms of democracy and civil rights rests not only with the right to protest but also with the right to move beyond one's own country in the pursuit of one's welfare or happiness (Mezzadra 2006, Sossi 2007).

I also share the view of those who consider trans-national migrations a major challenge to the prevailing economic, political and philosophical models of state-making and citizenship, hence the constant effort to 'de-politicise' them at state level (Malkki 1995: 509-10; Pérouse 2002). In this sense, today's transnational migrants are putting toserious test national and state identities and question the very roots

${ }^{3}$ The exception is of course the African Borderlands Research Network (ABORNE) set up by Paul Nugent in 2007 (see www.aborne.org) 
of our belonging to one country, language, race or religious group. Trans-border cultures need not be just 'open wounds' to be healed; they can help us to renew and extend the closed-in social contract we inherited from the nation-state and its strictly-bound frontiers. The hybrid and porous 'Tout-Monde' of Glissant (1997) is in progress in most European countries.

It is for all these reasons that I believe there is an urgent need to record, document and bear witness to this global process, and we must do it through the voice, writings and agency of its participants, actors and eye-witnesses. Whether they are victors or victims, whether they are able to pursue their migratory project to the end, their failure or success will be influenced not only by the contingencies of today's volatile international relations, but also by the way we, as scholars, are able to record and analyse the daily practices and representations of what appears to be the first continued wave of global migration post 1991 (McKeown 2008).

As to the Horn, when I was doing fieldwork in western Ethiopia in the early 1970s, I had to cross several geographical, linguistic and mental borders before understanding the historical growth of a small 'no-man's land' (a slave and gold district called Beni Shangul in western Ethiopia, now a minor, neglected 'state' of federal Ethiopia) whose local inhabitants (and identities) stretched over Ethiopia and Sudan. At that time, one did not pay much attention to the western Ethio-Sudanese border - "Frontiers used not to be marked on maps, and were scarcely more visible as one passed across them" (James 2002: 259) - and I was able to record trans-border histories of domination and resistance in an area whose wealth and people were equally coveted and raided by both the Mahdist State and Menelik's Ethiopia (Triulzi 1985). The coming of the Derg's rule in Ethiopia and the following period of state and interstate crisis put an early end to my cross-border research of Ethiopia's outer limit. When I went back to the field in Ethiopia in the mid-1990s, I was soon caught up in another unexpected detour: the lingering conflict between Eritrea, now a fully independent state, and federal Ethiopia which dramatically surfaced on the occasion of the long and still unsettled border war between the two countries (Tekeste and Tronvoll 2000). So, in a way, borders have haunted me as a researcher all my life.

In the Horn, borders have been haunting people for a long time. In the past fifteen years or so, the region of the Horn has witnessed 
an unending series of man-made and natural disasters: repeated drought throughout the region, genocidal practices (in Darfur), cross-border and internal guerrilla warfare (Southern Sudan and Ethiopia), a lengthy state of war over the demarcation of a colonial boundary (Ethiopia-Eritrea) and, more recently, terrorist threats and counter-terrorist military operations (in and around Somalia). The 1998-2000 conflict between Ethiopia and Eritrea caused no less than 100,000 casualties and over half a million people were displaced. The culture of war that ensued, coupled with increasing insecurity and political stagnation, led many people, youngsters in particular, to abandon their country to escape forced recruiting and economic deprivation (Tronvoll 2009). Since then, border crossing has no longer been an 'innocent' activity in this part of the world. Governments are making it difficult for people to leave, parents have to pay fines or go to prison if their sons and daughters try to elude their military duties by escaping to another country - to be expelled or arrested again by the countries they escape to for illegally entering them. Moving is becoming an increasingly transgressive activity, both in Africa and the West. Migration is inevitably part of this global mass transgression.

\section{Migrating, transgressing}

Cross-bordering has always implied, to a certain extent, transgressing. It is true for migrants crossing neighbouring countries and those travelling to far-away ones. It is particularly true for the ambiguous and ever-increasing category of asylum seekers who - in my country - are considered illegal and clandestine until they can prove their right to refugee status, a 'right' that is often difficult to prove within the existing Geneva-influenced norms of political asylum. To be 'clandestine' a condition which affects most African migrants in Europe nowadays -- implies not only the usual need to conform to the social habits, language and appearance that are accepted or prescribed by the host societies, but also subjecting oneself to various forms of camouflage, hiding one's own origin or acquiring a different one that is thought to lead to more rightful entitlements to refugee status.

Maintaining one's own identity can be risky or impossible in such conditions, as it may clash with the 'legitimate' identity as perceived by the recipient country's authorities. One's ethnic, religious or polit- 
ical belonging, and the real reasons for departing or wanting to stay, thus become more inscrutable and 'enigmatic' both for state authorities and the fleeing clandestine population. So migrants and asylum seekers are often forced to keep their real nature and expectations as an undisclosable truth, something that, like the marranos or conversos of 15th century Spain, they hold inside as an 'unchosen' secret which 'holds' them at the same time (Derrida 1996). Here lies the 'open wound' (herida abierta) vividly described by Gloria Anzaldùa of all border cultures: "Its inhabitants constitute what is prohibited and forbidden. Here live los atraversados [those who cross over]: the malignant, the perverts, the homosexuals, those who bother, the bastards, the half-caste, the half-blood, the half-dead; in a word those who cross, go beyond, overcome the borders of normality" (Anzaldùa 2006:29).

Migrants are often perceived as transgressors. Indeed, as the Latin word for migrate (migrare) implies, migratio denotes not only the act of moving or displacing but the very idea of 'trespassing rules and customs': communia iura migrare (Cicero, De divinatione, I, 8, in Vitale 2004:30). Migrants always live 'at the border' even when they are deep inside another country, torn between the 'here and there' of their multiple being - their identity, not just their body, being literally 'on the move' (Frederiksen and Sørensen 2002). This explains both the difficulties of state authorities in extracting 'true' statements about the migrants' 'real' reasons for coming and wanting to live in another country, as well as their reticence, their suspicious silence, their inability or unwillingness to express their inner self, to tell the true story of their life, their personal odyssey. According to most institutional bodies, including international ones, the 'naked nature' of man is yet be considered part of homo sacer and his inner rights (Agamben 1995), as states abide by rules and regulations that derive from internal or international law, not philosophical norms.

This implies that most illegal migrants - particularly those of young age - live in the host countries in a de-territorialised and also totally de-humanised solitude. In their inability to orient themselves in an alien universe of cryptic signs and messages, they are led to suppress their 'alien-ness' by cancelling, hiding, changing or denying their country, ethnic group or original home in their strenuous effort to come to terms with the internal or international norms of the host country. Not allowed to be what they are, they strive to conform them- 
selves to the accepted identities, origins or troubled areas of the world, which they believe will facilitate their being granted asylum or given a work permit. The continued transgression and hiding of the foreign migrant, his sense of solitude and shame for always 'appearing' rather than 'being', makes his marrano-like figure akin to the position of all false converts (conversos): they have to hide something they cannot disclose, and yet their very 'mimicry' (Bhabha 1997) is used against them. This is why, in most European countries today, particularly in places like Italy and Spain where the numbers of migrants have dramatically increased in the last years, migrants are made illegal by our own restrictive norms of inclusion and bureaucratic entanglements transforming them in most cases as Gastarbeiter, or foreign workers without rights, to the benefit of informal and illegal networks operating in the market.

More recent research among asylum seekers from the Horn of Africa in Italy (Koser 2003, Arnone 2005), Egypt and Sudan (Le Houérou 2004) has also shown that the new generation of Eritrean and Ethiopian youths escaping their countries for fear of war and political repression do not fit current standards for granting asylum. Most of their requests are rejected on the principle that they are based on 'economic' and not 'political' motivations. I have no time to deal with this highly complex issue here, except to say that it is extremely difficult nowadays to differentiate between these two falsely-opposed motivations, since political and economic situations in the region of the Horn, as elsewhere, are inextricably interwoven. Furthermore, what is perhaps even more disquieting, research has shown a real antagonism between the first generation of migrants from the Horn who came to Italy in the 1960 and 1970s and the present generation of youths escaping military recruitment and a future of no economic or political prospects.

To the old generations of Eritreans who came to Italy at the time of the war of liberation (which ended successfully in 1991) their opting out of the country at war was perceived as an alternative way of participating in the liberation of the country, a different but legitimate engagement with war times. The new youths aspiring to a brighter future today and eluding the country's military service are perceived by the second generation migrants as useless hooligans and 'traitors' to the country's cause. Thus, a generational conflict is piled up over a major political and economic gap by which 'those who made it' express anxieties over the destabilising effect of the 'poor and idle' newcom- 
ers, while 'those who hope to make it' reject both the nationalist call of their elders and the exclusionist policies of the Italian authorities. A whole circuit of 'narratives' and 'counter-narratives' is enacted at different levels by the older and younger generations (Arnone 2005)

A similar interplay of false 'truths' is enacted by the very mechanism of asylum itself in Europe. As Terence Ranger has shown for Zimbabwean refugees in England (Ranger 2005), both the asylum seekers' narratives presented to the Home Office adjudicators - guided by "solicitors and the 'street wisdom' of other asylum seekers on what they think the adjudicators want to hear" - and the uniformly-drafted Home Office 'counter-narrative' of refusal are 'flawed documents' which need close investigation of the new 'postcolonial encounter. Research carried out in Rome and Naples among asylum seekers from the Horn between 2007 and 2012 bears the same flawed evidence (Triulzi and Carsetti 2007, Uoldelul et al 2011: 313-334, Gatta 2012). Clearly, there is a need for all of us to rethink the inherent modes and causes for such institutional transgressions. There is also a need to find different places and ways of listening to migrant voices trying to escape both official truths and self-imposed denials.

\section{Reminiscing early fieldwork: making a home at Tiburtina Station}

An abandoned warehouse belonging to Tiburtina Railway Station in Rome was the first field that the initial group of researchers and volunteers decided to plough together. Tiburtina was both a field-site and an undefined space of human crossings (a sort of terrain vague) where migrant narratives were first collected for archive. The abandoned warehouse had been gradually occupied by squatting migrants mostly from the Horn of Africa in the late 1990s and early 2000s. The migrants were the first major influx of Black 'irregulars' to arrive in Italy from the Horn following Africa's succession of conflicts and post-conflict 'humanitarian' crises that ensued. The Tiburtina escapees were fleeing mainly from the raging Somalia of the post-Barre period, the Ethio-Eritrean conflict of 1998-2000 and the Darfur 'genocide' of 2003, all areas considered to be part of Africa's 'biggest humanitarian crisis' at the time. African migrants from the Horn went unnoticed in Italy at first, but gradually became the increasing target of media attention and a test to the government's ability to react to global crises. 
It was at that time that I was first asked by a friend of mine who had started an Italian language school for recently-arrived African migrants to join in a collective effort to understand and explain the migrants' reasons for escaping from their countries and their bewilderment (dépaysement) in the country of arrival. Academic knowledge per se did not help much, but we soon came to realize that our 'helping out' at the Italian school was not just a way of showing solidarity to young Africans stranded in our country but, as researchers involved in African Studies, it was our own métier that was questioned no less than our society's ability to cope with the challenges posed by the asylum-seeking African migrants (see www.asinitas.org). So I gladly joined in and took part in the school activities to familiarise myself with individual situations and stories and learn how to cope with people who had been seriously traumatised and were often unable or unwilling to narrate their untold suffering and anxiety. From the school premises, one room in a crowded apartment where the local NGO "Doctors against Torture" received patients and helped them to cope with the painful memories of violence, we were eventually led to the place where the migrants lived, a huge, vacant, three-storey warehouse belonging to the Italian Railway. The warehouse had been gradually occupied, mainly by irregular migrants temporarily accepted in Italy on humanitarian grounds, who refused to be locked in the various centres, actually containment structures, , set up by church or government and tried to recreate a less alienating place to live in the warehouse.

The warehouse was surrounded by a high wall, an iron fence and a locked gate and migrants had found their way into it by following the railway lines at night while looking for a place to sleep. Eventually they used a ladder to climb over the wall and dug a round hole that they had to stoop to go through. Surrounded by a large wasteland of trampled, dusty earth, the warehouse stood high in its incomprehensive emptiness. For five years (1999-2004), after lengthy negotiations with the Railway and Township authorities, and a hard-won agreement with the different migrant communities, they were allowed to stay as temporary squatters. There was no light, water or sanitation inside, although these were sparingly provided by the authorities outside the building. In fact the authorities paid little attention to Tiburtina until NGOs and journalists found it and started reporting about it. By then, most of the self-made internal structuring of the Tiburtina warehouse 
had been worked over by the migrants. At its peak, the warehouse was able to host about 500 migrants neatly divided into crammed partitions or cells ('rooms'), each family or individual migrant being free to open windows, raise flimsy walls, set up tables or beds with whatever they could lay their hands on, cardboard, cloth or tile. To the Italian public, the place came to be known (through the uncanny rhetoric of scoop-hungry journalists) as 'Hotel Africa'. African residents objected however to the 'heteronym':

Everybody now knows Tiburtina as Hotel Africa, but for us who live here, it is simply Tiburtina. We don't like Hotel Africa because you cannot call a place without water or light a hotel ... Tiburtina is not a hotel and it is not Africa, it is Italy (Field Notes, 7).

So they kept referring to it simply as Tiburtina. Among them they used the term kerba, or 'abandoned house', the 'house of house-less persons' (Ibid., 7, 49), a squatting place for irregular workers as they had been used to more than once in their nomadic wanderings. Yet, under those difficult circumstances, Tiburtina fulfilled the basic role of sheltering the 'homeless' and 'stateless' by providing them with material protection, food and a roof over their heads, as well as nurturing a well-grounded feeling of togetherness out of common needs, ties of kinship and shared longings. However temporary and squalid the new 'housing' was, it was all the migrants had, and they stuck to it, striving to make it as much as possible their 'home', or craving for a substitute home.

It may be interesting to remember how this came about, from the first group of 25 Sudanese refugees who discovered Tiburtina when walking along the rails at night. Here are some of the stories we recorded then:

We Sudanese thought only of two countries, England and Holland. The road took us here, to Italy. Nobody knows Italy, for us it is only transit, we had no one here in Italy, we were the first (Ibid., 47).

The upper floor was still empty. As new persons came in, we built the rooms. I made the first room on the first floor, the one at the end corner. We found some large pieces of cloth and we divided the space. Bit by bit, we found old mattresses, iron beds and all the rest (Ibid., 49).

When I first arrived at Tiburtina and saw it, the first thing I thought was I want to leave, to go away, I had no other thought but that (Ibid., 48). 
Yet in time Tiburtina became something different. Created out of nothing through migrant inventiveness, adaptation and ability to cope within hostile surroundings, it soon revealed the depth of social capital at the disposal of migrant groups. It thus became a 'transnational space' itself endowed with a new geography of fulfilled material needs, kinship ties and sociability. In the absence of state intervention, and contrasting societal indifference, a creative process of home-building took place until it was manipulated by the inroads of the media, who dubbed it 'Hotel Africa', and by the confused governance of state, church and NGO interventions that eventually led to the evacuation of its occupants. During its brief heyday as a multi-ethnic house, however, Tiburtina was described as "home away from home" for the different refugee communities:

When one arrives, one is zero, no money, no nothing. When I arrive here I find people, they say hello to me, you are a Sudanese, only this counts. All come and bring me things reserved for guests, eat, drink; they ask me how I feel, how I came here, where I came from, what problems I met, they allow me into their circle so that I do not feel I am an outsider, as if I had known them for a long time. I ask information to know whether I should stay or go to another country. I ask how the situation is here. They give me all the information: police, school, the public mess, the reception centre, work possibilities. If I want to leave they give me information how to go away. They take me to the station, they help me buy the ticket. If I don't have money, they put together the money for it (Ibid., 47).

And again:

If you work at a petrol station, you go out late at night and come back during the night. So you cannot go and sleep at the Township's reception centre, because there you are obliged to get in within a certain hour, otherwise your bed is taken. It was for this reason that we chose to live at Tiburtina, so that we could go out at night and work at petrol stations ... We did not want to sleep in a refugee centre, nor eat at the Caritas' mess. To eat there you always have to queue up and you feel sick too if you have to wait in line to eat, it is bad for us, we are young, we can work and do things ourselves ... Even to go to school, to make an appointment, to see friends, the centre and the mess are no good, you always have to think about their timing, you cannot decide whether you can do one thing or the other. At Tiburtina you can come and go as you please, you can make things normal (Ibid., 48).

To make things normal was, for the Tiburtina dwellers, to be able to reconstruct as far as possible a human environment where they could 
re-locate themselves and reconstruct their social identity as migrating humans. It became a resting place for people on the move needing a human setting where wounds and suffering could be healed, feelings of friendship could be renewed, projects of further migrancy developed on the basis of local knowledge, individual emotions and joint needs. Not all succeeded, of course, and to some Tiburtina was simply a place of refuge and isolation from a hostile world, a place to withdraw and get drunk, or simply lie back:

One should not stay too long here. It is good as a place of arrival and departure but if you stay here for one, two or three years, then you'll get sick ... After a while ... you risk spending all your time thinking about your life, you keep thinking while time goes on and on. Little by little you risk losing the strength to do all that is asked from you, so you get sick, start drinking and then you feel even worse ... If you are afraid, Tiburtina protects you, it is a place where you can disappear. Often I want to stay by myself and want only to think, and don't want to go out at all ... When I am out of Tiburtina I feel I am in Italy, but when I am inside I feel I am still in Africa (Ibid., 8).

Communal life helped and in some measure healed. Seen from the outside, the Tiburtina compound and its surroundings presented the familiar sight of any crowded favela or busy bidonville of an African town. During the day, one could see women chatting, washing, ironing, cooking or feeding babies, while men had conversations or made deals on broken chairs and discarded furniture. Inside the building at all times

there is a constant shuffling of people, some mend a broken door or a room partition, here and there people group together around a card table, the outside wash basins are always crowded with persons washing their teeth, face, feet, clothes or shoes, they fill buckets, pots or bowls with water which they carry on shopping trolleys ... Someone gets shaved, is having a haircut or dyes his hair... At any time during the day people play pinball. Inside the warehouse you can find the Sudanese restaurant of Adam, the grocery and the laundry of al-Faki and Ciolle, the broad-bean and, during summer, the milk-shake kiosk of Saleh; above, on the first floor, there is the Eritrean coffee shop of Said ... (Ibid., 12).

The feeling of belonging to the migrant community encompassing various ethnic groups was ensured at higher level by formal committees of representatives elected on an ethnic basis. In a more informal and spontaneous way, specially trusted persons within each commu- 
nity made sure that intergroup relations developed along negotiated dealings of give and take. It was this constant mediation of diversified needs and identities reflecting different migratory projects, people who only needed a place to stop over and a junction from which to branch off in different directions, that made the self-disciplined Tiburtina an irreplaceable 'trans-national space' which showed the migrants' abilities to shape, construct, adapt and mould, if only they are allowed their own world of reference, solidarity and exchange.

After the journalists re-named Tiburtina 'Hotel Africa' and the area became a constant target of social and gawker sightseeing, the state and a plethora of well-meaning bureaucrats, architects and planners arrived. It was they who decided one day that the migrants' terrain vague of Tiburtina was too unhealthy, too left on its own, and had to close down. The railway soon re-appropriated the abandoned warehouse and its premises. As major repair works started around 2006, the squatting migrants scattered or simply moved out. The whole area was cleared, fenced in, and controlled day and night so as to avoid new forms of squatting. In the following years the railway buildings and warehouses were gradually up-graded to fit the renovated station. Tiburtina Station soon became a busy traffic area, a crossing for fast-walking, anonymous customers. The new station was inaugurated in December 2011. A fast-track private line connecting it with Milan in less than three hours was opened in 2012 (www.leonardo.it). Thinking back, we must realize that the story of Tiburtina's squatting days could only be traced by going back to migrants' own memories. The station's grounds were sanitised, but not their memory - not all of it, not yet anyway.

It was against this background that a group of us decided that stories such as Tiburtina should be recorded and as far as possible documented through the eyes of their actors and interpreters. Since then, the original group of researchers, volunteers and migrants has split in different directions, opened other schools, made films and videos and published books. The Archive of Migrant Memories (www. archiviomemoriemigranti.net) was born out of this collective, participatory experience. The idea of compiling an archive of memories made by and for migrants came out of a joint effort to make migrant memory a valuable common good to all, and through it build wider public awareness in Italy. The archive's aim was to put researchers and 
migrants together so as to allow migrants to participate directly in the collection and diffusion of their own stories and testimonies

Today we badly need to trace back and analyse all the Tiburtinas of the contemporary age if we want the memory of our first encounters with incoming foreigners to give sense and direction to the multicultural societies we increasingly live in. One would hope that African Studies and ECAS conferences are an intrinsic part of it.

\section{References}

Agamben, Giorgio.1995. Homo Sacer. Il potere sovrano e la nuda vita. Turin: Einaudi. Akyeampong, Emmanuel. 2000. "Africans in the Daspora: The Diaspora and Africa". African Affairs, 99:183-215.

Amin, Samir. 1995. "Migrations in Contemporary Africa: A Retrospective View." In Jonathan Baker, and Tade A. Aina, (eds.) The Migration Experience in Africa, NAI, Uppsala.

Apopkari, J.K. 1999. "The Political Economy of Migration in Sub-Saharan Africa”. African Sociological Review, 3, 1.

Anzaldùa, Gloria. 2006. Terre di confine. La frontiera. Bari: Palomar.

Arnone, Anna. 2005. "I viaggi verso l'esilio: l'elaborazione dell'identità eritrea tra esperienza e narrazione.” In Riccio, Bruno 2005:82-95.

Bhabha, Khomi. 1997. "Of Mimicry and Man. The ambivalence of colonial discourse." In Tensions of Empires, Edited by Frederick Cooper and Ann L. Stoler. Berkeley, Los Angeles, London: The University of California Press, 152-160.

Byfield, John (ed.). 2000. "Rethinking the African Daspora". African Studies Review, 43,1 .

Chelati Dirar, Uoldelul, Silvana Palma, Alessandro Triulzi, Alessandro Volterra, eds. 2011. Colonia e postcolonia come spazi diasporici. Attraversamenti di memorie, di identità e confini nel Corno d'Africa Roma: Carocci, 406 p.

Ciafaloni, Francesco. 2005-06. "Meteci”. Lo straniero 66/67: 98-105.

Derrida, Jacques. 1996. Apories. Mourir-s’attendre aux 'limites de la verité. Paris: Ed. Galilée.

Fieldnotes (1999-2004). “a tiburtina giù la piazza più nessuno” Extracts, documents and fieldnotes prepared by Marco Carsetti, Asinitas, Rome.

Frederiksen, Bodil F., and N.N. Sørensen (eds) 2002. Beyond Home and Exile: Making Sense of Lives on the Move, IDS Occasional Paper 23, Roskilde, 5-14.

Gatta, Gianluca. 2012. Luoghi migrant. Tra clandestinità e spazi pubblici. Cosenza: Pellegrini.

Glissant, Edoard. 1997. Traité du Tout-Monde. Paris: Gallimard.

Gomez, Marco A. 2005. Reversing Sail. A History of the African Diaspora. Cambridge: Cambridge University Press.

Grillo, Ralph. 2000. “Riflessioni sull'approccio transnazionale alle migrazioni”. In Riccio 2000: 9-16.

James, Wendy. 2002. "No Place to Hide. Flag Wawing on the Western Frontier." In Remapping Ethiopia. Socialism and After. Edited by Wendy James, Donald L. Donham, Eisei Kurimoto, Alesssandro Triulzi. Oxford: James Currey, 259-275. 
Kaarsholm, Preben, and Abdul Sheriff. 2012. "Special Issue: Mobility, Diasporas and Transnational imaginings in the Indian Ocean." Social Dynamics 38, 3.

Klepp, Silja. 2010. "A Contested Asylum System: The European Union between Refugee Protection and Border Control in the Mediterranean Sea." European Journal of Migration and Law 12, 1:1-21.

Koser, Khalid. 2003. "Mobilizing New African Diasporas. An Eritrean Case Study." In K. Koser, Khalid (ed). New African Diasporas. London and New York: Routledge.

Le Houérou, Fabienne. 2004. Migrants forces éthiopiens et érythréens en Egypte et au Soudan. Paris, L'Harmattan.

Malkki, Liisa H. 1995. "Refugees and Exile: From 'Refugee Studies' to the National Order of Things". Annual Review of Anthropology, 24.

McKeown, Adam. 2008. Melancholy Order: Asian Migration and the Globalization of Borders. New York: Columbia University Press.

Mezzadra, Sandro. 2006. Diritto di fuga. Migrazioni, cittadinanza, globalizzazione. Verona: Ombre Corte.

Mohan, Giles and Alfred B. Zack-Williams, (eds). 2002. "Africa, the African Diaspora and Development". Review of African Political Economy, 92.

Negash, Tekeste, and Kjetil Tronvoll, eds. 2000. Brothers at War. Making Sense of the Eritrean-Ethiopian War. Oxford: J. Currey.

Patterson, Tiffany R., and Robin D.G. Kelley. 2000. "Unfinished Migrations: Reflections on the African Diaspora and the Making of the Modern World". African Studies Review, 43, 1.

Pérouse de Montclos, Marc-Antoine (ed). 2002. "Réfugiés, exodes es et politique", Politique africaine, 85.

Sossi, Federica. 2007. Migrare. Spazi di confinamento e strategie di esistenza. Milano: Il Saggiatore.

Ranger, Terence O. 2005. "The Narratives and Counter-narratives of Zimbabwean Asylum: female voices". Third World Quarterly, 26, 3.

Riccio, Bruno. 2000. "Emigrare, immigrare, transmigrare", afriche e orienti, 2, 3-4:440.

Riccio, Bruno. ed. 2005. "Migranti africani in Italia: etnografie" afriche e orienti, 8, 3:12-132.

Van der Veer, Peter .1995. "Introduction: The Diasporic Imagination". In Peter Van der Veer, ed, Nation and Migration: The Politics of space in the South Asian diaspora. Philadelphia: Philadelphia University Press, 1-16.

Triulzi, Alessandro. 1988. "La frontiera. Note su alcune recenti pubblicazioni di antropologia e storia etiopica”. Rassegna di Studi Etiopici, XXXI, 1531.

Triulzi, Alessandro. 2012. "Per un archivio delle memorie migranti." Zapruder, 28: 118-123.

Triulzi, Alessandro, and Robert McKenzie, eds. In print. Long Journeys. African Migrants on the Road. Leiden: Brill.

Tronvoll, Kjetil. 2009. War and the Politics of Identity in Ethiopia. The Making of Enemies and Allies in the Horn of Africa. Oxford: J. Currey.

Vitale, Ermanno. 2004. Ius migrandi. Figure di erranti al di qua della cosmopoli. Torino: Bollati-Boringhieri.

Zack-Williams, Alfred B. 1995. "African Development and African Diaspora: Separate Concerns?". Review of African Political Economy, 65. 


\section{OVERCOMING THE COST TO AFRICA OF BEING A GOOD NEIGHBOUR TO DENMARK: UNCONSTRAINED GEOGRAPHY AS AN ALTERNATIVE TO THE END OF HISTORY}

\section{John Davies}

\section{Introduction}

This chapter is intended to examine the multinational dynamics that impact on state-building and consider how notions of agency around state-building might be experienced by young Africans according to the globalizing practices and policies that are presumed to herald the end of history. It particularly considers the impact of certain globalized presumptions regarding the desirability of "... getting to Denmark" (Fukuyama 2004, 30) and contests the essentialism that presumes all nation states are able to follow a trajectory of institution building and development that will eventually result in a secure and safe capitalist society. In this context Denmark is examined and considered a specific nomenclature for any secure liberal democracy that operates as a capitalist market-driven society.

The chapter imagines a common post-modern border between an aged Denmark and a young Africa (Davies 2007). This very malleable device is then laid over various topologies and different geographies to deliberately contrive linkages between diverse discourses. This conflation between the various border discourses is intended to simulate a stream of consciousness regarding the interrogation of the imagined border rather than develop well grounded arguments. The interrogation is intended to ascertain how the bordering dynamics it attempts to engage with are visualized and experienced from above and below (Newman 2006). However like a Tennessee Williams play the principal characters in this chapter can suddenly change or present new and different attributes that can conflict with previously established parameters. These almost irrational realignments require immediate accommodation so the interrogation can continue uninterrupted to its eventual, raggedy conclusion. 
Firstly the imagined border is considered to be a tool used by Denmark to subjugate constrained populations of the young so the value of their labour can be asymmetrically and disproportionally used to benefit an aged Denmark. This benefit to Denmark is achieved by deliberately denying young Africans the benefits of actual and social mobility (Abel and Bernheim 1991, Solon 1999). Consequently it is posited that the wealth and privilege that has been accumulated by the old in Denmark requires other subaltern non-Danish states to allow their young populations to be constrained so they cannot freely transact for the value of their labour. This chapter examines the use of the African border as a means of constraint, rather than other constraints such as conflict or under-education, so as to focus on this specific role of the imagined Danish/African border.

In particular the chapter contends that the purposes of a border should be named and articulated in the order of their impact on affected groups. In seeking to identify the order of impact upon different stakeholders this chapter considers the conceptual value of good neighbourliness in understanding African borders. This aspect of the apartheid canon specifically used the manipulation of borders to create un-free labour (Cohen 1983). The constrained geography ensured the availability of exploitable labour by constraining the target population within a diminishing and increasingly unviable economic space. This constrained space compelled the population to offer themselves for labour at wages dictated by those who controlled their containment. The chapter therefore examines the influence of Verwoerd' $s^{1}$ apartheid notion of good neighbourliness as being an essential concept in building and sustaining Danish economic and political security.

Therefore this analysis crudely and bluntly posits aging Denmark as increasingly securing and protecting underserved privileges at the expense of young non-Danish people who are denied by constraining borders the ability to freely transact for the real value of their labour. Many other useful considerations, factors or nuances are laid aside or simply ignored in the pursuit of identifying this particular contest and contending for its preeminent place in offering an alternative to Denmark and the end of history. Notions of contested power and privilege have previously been articulated as the differentials between first and

${ }^{1}$ Hendrik Frensch Verwoerd was Prime Minister of South Africa from 1958 until his assassination in 1966. He is remembered as the man behind the conception and implementation of apartheid. 
third world, developed and less developed, north and south and other dichotomies. This chapter argues that the impending marker of the evolving contest for privilege will be that of the aged Denmark versus the young other and that this contest will contend for anarchy in an unconstrained geography as a more equitable end of history than the continuation of Danish privileges.

The chapter also examines the conflated discourse surrounding the porosity of exclusionary and constraining borders and claims that the preference within Denmark for privileging discussion of exclusionary borders and labourers who access Denmark has acted as an epistemological obstacle to understanding the greater impact of the constraining border upon Africa. Therefore the discourse that privileges the analysis of these exclusionary Danish borders is discussed and then challenged as distracting from an analysis of the borders used by Denmark to constrain non-Danes in easily exploitable serfdom. Consequentially the preferred limological tautologies that presume and repeat that the State's right to control its own borders are legitimate and furthermore that such borders can be extended to include constant controls over any individual located within the total national geography or can be juxtaposed extra-territorially (Nicholson 2011, Shields 2009) are questioned. The privileged visibility and xenophobic nature of the exclusionary border is identified not only as morally objectionable and contradictory to the demands of an effective, equitable globalized economy but as also as a distraction from an urgently required discourse on the uses of the constraining border. The deconstruction of the exclusionary border discourse becomes a method for the production of knowledge about the Danish constraining border in Africa.

Subsequently the chapter re-examines the imagined Danish-African border and how ensuring the viability of Denmark requires the borders of Africa to be the location where re-enacted apartheid practices secure the sustainability of Denmark's asymmetrical economic privileges and political security. It is then argued that, as Denmark perpetuates the Herrschaft und Knechtschaft, or master-slave dialectic (Hegel 1977)

${ }^{2}$ Anarchy is often defined as a political philosophy which holds the state to be undesirable, unnecessary, or harmful. However, others argue that while anti-statism is central, it is inadequate to define anarchism. Therefore they argue, alternatively, that anarchism entails opposing authority or hierarchical organization in the conduct of human relations, including, but not only, the state system. Proponents of anarchism known as "anarchists", advocate stateless societies based on non-hierarchical voluntary associations. 
rather than being an example of an equitable Kojevian homogeneous, universal society (Kojeve, Frost and Howse 2007) and as subjugated states cannot achieve the privileges and benefits of being Danish, as the Danish state requires them to exist as serfdoms, it is in the interest of young Africa to dismantle constraining borders.

The modalities and consequences of dismantling various African borders are briefly considered, as is the interim utility of increasing porosity. In considering the demographic threat to aged Denmark, the chapter, examines how the young and poor will be able to disrupt Denmark's ability to constrain or exclude them by dismantling borders. This anti-essentialist analysis of how states are differently positioned (Hanson 2009) and relate to the Danish ideal places Danish use of the African border as a prime diagnostic and analytical tool in researching the value of such borders to Africa and suggests that dissolution of constraining borders poses a dynamic challenge to Danish hegemony. Finally it is contended that the dissolution of the constraining border will make Denmark and the less excluding border unsustainable, so requiring history to move past Fukuyama (1992) end times to a new and unpredictable eschatology driven by the power of labour towards anarchy rather than communism or repeated cycles of interminable democratic governance.

\section{What and where is Denmark?}

Throughout this chapter actual Denmark and imagined Denmark collide and are often conflated and confused. Although a better denouncement of the two differing entities might have been conceptually helpful, the confusion accurately reflects the often cavalier use of "Denmark" in the end of history discourse that presumes Denmark to be a very identifiable entity. This confusion is possibly casual or clumsy but is certainly a means by which protagonists can escape scrutiny of certain of Denmark's attributes.

Fukuyama describes his notional and desired state of Denmark as, "...a developed country with well-functioning state institutions ..." (Fukuyama 2004, 30)

Recently in Cape Town, Fukuyuma (2011) recapitulated his critique of African borders as colonial devices that were mostly irrational irrelevances to the underlying African societies. However he presented 
these colonial borders as a means by which nation-building processes in Africa were derailed and modern sub-Saharan Africa was afflicted by the absence of strong indigenous states as a result. He further criticized failed post-colonial attempts to make African states look like Denmark because he believed the donor community did not properly consider how long it took to develop strong institutions as are typified in the Danish states. However these irrational borders were accepted as the incontestable determinates of modern African states and were not particularly identified as insurmountable or even serious obstacles to getting to Denmark.

In regard to its other attributes and the transferability of Danish competencies he continues, “... we know what 'Denmark' looks like, and something about how the actual Denmark came into being historically. But to what extent is that knowledge transferable to countries as far away historically and culturally from Denmark as Somalia and Moldova?" (Fukuyama 2004, 30)

While Fukuyuma questions the methods that are intended to create Denmarks out of weak States, he apparently presumes that Somalia and Moldova would benefit by eventually getting to Denmark. Furthermore he assumes that Denmark is a state of being that is available to any nation able and willing to acquire the necessary attributes of good governance. The contentions and discourse are focused on the internal barriers to becoming Denmark. These barriers which debatably require various time consuming and lengthy periods of transformation are prioritized as the problems needing resolution. As a result, the borders that are used to determine the geography of the state in transformation are reduced to inconsequential accidents of history that now diffidently act as a wrapper around the essential modern African state.

However it is how the borders are experienced by young Danish and non-Danish Africans that can speak loudest to the desirability of perpetuating Denmark. Borders are the location of many and various conjunctions and they can perform numerous tasks that define identity and being (Hanson 2009). Although extremely reductionist the Danish-African borders may be experienced by most young Africans simply as exclusionary or constraining. The Danish border is experienced by nonDanes as a tall fence around an exclusive club whose rules for admission are often inanely complex, irrational and substantially unachievable; however this border is experienced by a Dane like opening his garden gate to enter or leave own home (Agnew and Corbridge 1995, Bigo and 
Guild 2005). The African border is experienced by young Africans as a securitized zone where they can be interdicted and subjected to irrational interrogation about their intended mobility (Laitinen 2001). The young African experiences this border as a prison wall that must be broken through, after which there is a long and arduous escape to some other place. The Dane hardly experiences any such constraining borders. If a Dane does cross such a border he usually arrives like the prison visitor with documents and permission to enter the constrained area to visit for a while, and he is not the subject of the border's intent at any time. Since the fall of the Iron Curtain, most European Danes have not had experience of a constraining border. If the border is essentially the contrivance by which young Africans are to be used as demographic fodder for aging Denmark when other attributes, considerations and functions of these borders are stripped away, then Africa needs to find alternatives to this exploitation.

If the idealized state of Denmark is an indicator of the impending end of history because of its exemplary democratic capitalism is actually using African borders to maliciously exploit non-Danish people then Denmark can be better identified by Hamlet's suspicion of Denmark as being a "rotten State" (Shakespere 1992). If Denmark can only exist when it is able to subsidize its existence by using effective local borders to exclude,but more importantly by using other distant African borders to constrain an exploitable labour force in conditions that would not be permitted within Denmark, then Denmark cannot exist without perpetuating chaotic or repressed non-Denmark states. It is the constraining borders that allow the maximum appropriation of the surplus value of the excluded others' labour (Agnew and Corbridge 1995, Cooper 2010). Therefore what Lindberg (2005) considers Fukuyuma's desired world outcome of peaceful market-oriented democracies, which are supposedly typified by Denmark (Fukuyama 2004), can be disgarded and any Denmark can be reconstructed as a dangerous proto-apartheid state that only intends to ensure the material prosperity and civic freedoms of Danes. This is achieved by utilizing the competency and powers of an effective, well governed state to protect the privileges of Danes from the aspirations mostly of the young and invisible. This considers the borders that effect this exclusion as the deliberate consequences of a determination by Denmark to impose an unequal international dual market for young labour. A consequence of this demographic rapacity will enable aging Denmarks to acquire the benefits of African youth 
while Africa loses the demographic window for negotiating for more equitable transactions. If Africa loses the possibilities of its present demography because its youth is co-opted into serving Denmark on prejudicial terms or if its youth becomes a wasted resource trapped inside a constrained geography, Africa will become increasingly aged and poor, while Denmark will remain aged and rich (Johnson 2012, Abel and Bernheim 1991).

This conceptualization posits the purpose and use of the constraining border as the more important representation of the border experienced by Africa rather than the exclusionary borders that surround the physical geography of any Denmark. The use of the constraining border has a particular poignant history in Southern Africa and its purpose is best demonstrated by the apartheid era's Good Neighbour policies.

\section{Denmark's good neighbours: The use of the constraining border}

The purpose of creating neighbours through the good neighbourliness policies of apartheid was not primarily separating races but rather the specific economic purpose of creating disposable cheap labour (Welsh 2000). Apartheid's borders constrained people within geographies where it was impossible to survive without resorting to paid labour for the powerful border-controlling communities. If competent market-oriented democracies want to ensure the benefits of cheap labour to their economies they must constrain this labour in places where it can be exploited and denied the costly rights and privileges that are accorded Danish workers (Arrow and Debreu 1954, K. Arrow 1972). Without constraining borders labour could be expected to re-locate to labour markets where they can secure more of their own labour value (Agnew 1998, Banerjee and Newman 1993). While such constrained labour is overwhelmingly the exploitable labour of choice, at various times and places it has been necessary, however, to allow mobility of labour into Denmark (Sen 1999, Spivak 1996). This section examines the porosity of the constraining and excluding borders and considers how the consequences of this porosity have come to dominate political discourse on borders and the non-Danish labourer.

Apartheid borders were essential in constraining local economic opportunities to the point where the neighbours were compelled to seek to sell their labour at artificially low cost. This coerced surplus value of 
labour created an exceptional economic subsidy for those who could implement and control such borders. If borders did not sufficiently constrain a population and coerce it into accepting exploitative wage labour, borders were redrawn or populations were manipulated until the constrained geography compelled the acceptance of serfdom (Welsh 2000). Once this labour was no longer required the labourer was to be returned to live within the constrained geography. This mobility between the constrained geography and the actual labour market location required both the constraining and excluding border to be porous. This porosity then created problems regarding the effectiveness of the mechanisms intended to ensure the return of exhausted or unwanted labourers (Van Munster 2009). While effecting returns has become increasingly problematic the political determination to return unwanted labourers has remained a consistent feature of immigration controversy (Bigo 2000, Guild and Bigo 2010).

Welsh (2000) details how Verwoerd's government deliberately constrained Black Africans in areas that were able to support less than half of their populations so as to compel them to accept wage labour within the Europeans areas. Verwoerd's Department of Native Affairs' objectives for the Bantu homelands were specific with regard to their manipulation of the constrained labour market.

It is accepted government policy that the Bantu are only temporarily resident in the European areas of the Republic for as long as they offer their labour there. As soon as they become, for one reason or another, no longer fit for work or superfluous in the labour market, they are expected to return to their country of origin or the territory of the national unit where they fit ethnically ... (Welsh 2000, 499)

This apartheid labour migration policy deliberately commoditized labour migrants and reduced them to a disposable resource. The labour migrant was valued in as much as he could offer a benefit to the economy of the controlling state. However his labour was not considered to give the migrant a place or part in that state enterprise. In fact he was institutionally excluded from becoming a member of the community that benefited most from his labour. Contrived borders then allowed the exploiting master class to remove such a migrant to a constrained geography that confirmed his otherness and exclusion (Agnew and Corbridge 1995). The power and utility of such borders are being rediscovered by most Denmarks, and many of these borders are now being reinforced to ensure that benefits can be secured for the Danes (Guild 
and Bigo 2010). The migrant whose labour is no longer required inside the host community becomes useless to it and as such his legal right to remain in that place can be withdrawn and yesterday's legal labour migrant becomes today's illegal immigrant (Harle 2000).

In short a system that actually controls migration for the good of this country ... that doesn't just sound tough, but is tough ... Of course, immigration is not just about people coming to live here for a while. Some will want to settle and then join us as fellow British citizens. But it's been too easy to come to work and then stay on. It was virtually an automatic progress. We are going to break the link between work and settlement. Only those who contribute the most economically will be able to stay. And we are consulting the Migration Advisory Committee on how best to do this ... For our part in government; we are creating a new National Crime Agency with a dedicated Border Policing Command which will have responsibility for safeguarding the security of our border. But I want everyone in the country to help ... including by reporting suspected illegal immigrants to our Border Agency through the Crimestoppers phone line or through the Border Agency website. Together we will reclaim our borders and send illegal immigrants home (Cameron 2011).

However the effectiveness of such policies is predicated on the state's ability to police itself internally, using an increasing panoptical view (Foucault 1977, Shields 2009) overall and having the ability to remove unwanted foreigners to another place. Guild and Bigo (2010) have spoken extensively on Denmark's desire to acquire such panoptical powers. Recent developments include a crafted mix of brute power and panoptical surveillance.

... telling credit reference agencies about illegal immigrants so they can't get easy access to credit ... ensuring the UK Border Agency and HMRC work together more closely to come down hard on rogue businesses which use illegal labour to evade tax and minimum wage laws... and creating biometric residence permits - which just like a biometric passport -gives employers much greater certainty over who they are employing and their right to be in the country (Cameron 2011).

The good neighbour therefore offers his neighbour paid work to compensate for the inadequacies of the space in which he has been confined by the borders created by the good neighbour. Confronted by the 'natural justice' of such borders, which were to Verwoerd as obviously and divinely appointed as the mountains and the seas, it behoves the constrained neighbour to accept the ordained order. To rebel against this world order is to declare war on privileged Denmark and to invite the consequences of challenging that order. 
What only states and states alone are able to do is aggregate and purposefully deploy legitimate power. Power is necessary to enforce a rule of law domestically, and it is necessary to preserve world order internationally (Fukuyama 2004, 120).

However power is now exercised in a more nuanced and effective way than the simple brute repression of the poor as used by the forces of apartheid. Foucault (1977) recognized that effective control can be exercised by overarching panoptical processes that simply administrate people into submission. Administration of the various borders directly or through proxies is central to Denmark's ability to control and constrain labour and particularly to subvert any power that might accrue to the young African (Fanon 1967). The World Trade Organization's General Agreement on Trade and Services which through Mode- 4 would allow labour to move freely as goods and capital has been stymied in the Doha round of negotiations for many years. Danish countries with developed labour markets that would afford migrant labour significant protections and rights continue to reinforce barriers to the free movement of labour and so especially constrain young labour from participating in the old capitalist market place (Davies 2007).

In considering the importance of competent, market-oriented democracies to the end of history no requirement is made for this market orientation to include a commitment to a free market in labour. The failure to allow labour to freely transact in the market is considered by Sen (1999) as a major societal issue. Sen sees the denial of free seeking of employment as an un-freedom (Cohen 1983) and a form of labour bondage or serfdom that is a major deprivation of those excluded from participating in certain labour markets.

... the absence of the freedom to transact can be a major issue in itself in many contexts. This is, of course, particularly so when the freedom of labour markets is denied by laws, regulations or convention (Sen 1999, 113).

The world order that is dominated and defined by Denmark is one where non-Danish labour is overwhelmingly constrained by layers of borders that are intended to compel it to make itself available for exploitation by privileged Danes either within the constrained space or temporarily within the "European areas" of Denmark (Agnew 1998). Increasingly, a non-Danish labourer who passes the porous border is considered a problem that must at least receive intense scrutiny, marginalization and increasing panoptical control (Bigo 2000, Laitinen 2001). Howev- 
er Danish concern about those who pass the porous border needs to be reviewed in relation to the control of those who are unable to pass the constraining border. This population is far larger than those who cross borders and is arguably a much greater resource for exploitation by Denmark (Skeldon 2003).

The market mechanism of such a Denmark is based on perpetuating a real un-freedom ( (Elster 1979) that protects the existing 'pareto optimality's advantages experienced by Danes. Arrow-Debreu (1954) clearly conceptualizes how market mechanisms can be perverted to accrue extra utility for those able to control access to a market. Borders used to constrain the formal freedom that workers had acquired under capitalism to change employers and dispose of their labour more equitably, actually revert captured labour to a pre-capitalist serf-like state. When these constraining borders are located in Africa, their purpose needs to be re-examined and they should be set aside if inappropriate to the well-being and development of Africa. The fact that these borders can concurrently serve various purposes as well as perpetuating un-freedoms should not dissuade Africans from dismantling these apartheid processes and replacing them with more equitable mechanisms. The monies invested in the institutionalization of this xenophobia and the associated exploitative value of constrained labour that will benefit mostly Denmark will be unavailable for the building of positive regional institutions intended to promote the benefits of a single regional market.

In constructing its constraining borders Denmark has created a common Danish-African border that is little understood and is often unseen as a nexus between Denmark and its subaltern clients.

\section{The Danish-African border: The evolution of a post-modern border}

Denmark and Africa now have a considerable imagined border that separates the two connected geographies in a variety of ways. The location of Danish borders so as to surround Africa is a work in progress but the efficacy of their power to separate Danes and non-Danes is growing. However these borders are seriously contested by many non-Danes who seek to gain unqualified access to Denmark. These transgressions are the compelling motivation for the layered borders that are eventu-

\footnotetext{
${ }^{3}$ A Pareto Optimal outcome cannot be improved upon without hurting at least one player.
} 
ally implemented as the internal controls able to sieve a population for interlopers (Nicholson 2011, Kolossov 2005).

However this Denmark that is constructed as a place of ideas and competencies can still be viewed as a bordered regime that also defines a place that is non-Denmark. The continuum that encompasses the physical and political Denmark reaches through into imaginations of a meta-physical Denmark that is used to inform the goals of development and progress (Lindberg 2005). All these Denmarks are existent and extant because there are borders that separate them from non-Denmark. These borders act as points of interlocution where Denmark and non-Denmark can speak to one another about their differences and possible interdependencies (Salter 1992).

Where the common border between Denmark and Africa as non-Denmark now exists becomes the nexus where we can best interrogate and understand the possible consequences of "... getting to Denmark". If we can understand the purpose of a border we can better understand the nature of the place it is used to encapsulate (Salter 1992). It is an understanding of Danish borders and the relationships they command and seek to control that speaks with far greater moral exactitude about the nature of Denmark than any observations of what Danes do and experience inside Denmark.

The reorganization of the state rather than its disappearance has been a recurring subject of analysis in the post-modern discourse on nations. Increasing hybridity (Agnew and Corbridge 1995, Arxer 2008) was argued to have reduced the importance of the state, especially because the power exercised on the border had become an irrelevance in the globalized economy. In fact discussion of how the nexus of power and the border could be formulated and discussed became increasingly fraught (Arxer 2008, Kolossov 2005). African borders are particularly troubled locations in that they are often the legacy borders between European states. Consequently their legitimacy has been the subject of extensive pan-African interrogation (Fanon 1967) and investigation. However the role of such borders in serving a particular course of supposed world economic determinism rather than reproducing tired colonial rhetoric around geography and people is not well researched.

The place of African borders as having functional disparity when compared with Danish borders requires them to be theorized and understood as qualitatively different institutional arrangements. If African borders are shown as having been invested by Denmark with the re- 
sponsibility of acting as outlying protective frontiers, this would show African borders as being contrivances intended first to ensure Danish priorities before assuming any local or regional role. However the discourse on the constraining border is often occluded by the much louder and more researched excluding border (Agnew and Corbridge 1995).

\section{Privileging Denmark's excluding border discourse}

In theorizing the borders that surround Denmark, it is important to properly locate the geography or population that is being affected by them. Historically borders were often the creation of physical geography. Rivers, mountains, seas and deserts were all regularly pronounced as borders. However physical geography became subservient to populations' ability to declare a place as belonging to them and their means to exclude others from that place by enforcing a dividing border (Agnew 1998).

The nation state became the institution by which European borders were established and defended. Westphalian notions of statehood saw borders as the means of acquiring identity, security and sovereignty by excluding those who would corrupt or otherwise dispossess the resident citizenry of the advantages of occupying the protected space (Agnew 1998). The secured geography was then available for the exploitation of the powerful, often through the use of bonded or serf labour (Cohen 1983). This exploited labour was greatly relieved by the freedom of eventually being able to transact in capitalist economies, but the contest of how to capture the maximum amount of the surplus value of their labour continues (Cohen 1983).

Fears of violent displacement or occupation have mostly receded in Europe with the notable exception of the Balkans. However the fear of being swamped or overrun by those who would usurp or dilute European privileges is a pervasive, constant worry for many Danes (Van Munster 2009). However this chapter argues that the most important feature or purpose of Danish borders is not their exclusionary powers, but the ability to increasingly confine non-Danish labour into smaller and less viable territories where it can be compelled to accept serf-like conditions of service.

An observable point in which Danish exclusion is prominent in the public domain is in the discourse taking place in actual Denmark 
around exclusionary border control. Actual Denmark was the source and inspiration for the "getting to Denmark" exemplar, and as such invites examination to better understand what is experienced by those who want to go to Denmark. "Getting to Denmark" is presented as not just arriving at a political philosophy but the implementation of that political philosophy and economy in a particular geography. It is therefore useful to examine how the exclusionary border has become so privileged in the discourse around Danish borders to the point where Danish constraining borders are almost invisible and unnamed. The Danes are supposedly protected by effective state power and violence against non-Danes who are considered threatening to Danish culture and prosperity. This state machinery will then require the constant identification of others as a threat to local society to justify its operation (Harle 2000). However this narrative of cultural threats and economic risks presented by others as requiring the security of Danish borders against them is actually the antithesis of why such borders are really required.

In the confusing plethora of border control narratives, post-modern border control has become increasingly theorized as a means to control a population rather than to control a specific geography (Guild and Bigo 2010, Arxer 2008, Newman 2003, Newman 1999). The post-modern border when compromised by others becomes a transgressional space that follows the targeted migrant. The conceptualization of this imagined border allows the border to be removed from any particular geography. The post-modern border becomes a legal and social bubble that contains only the illegal migrant and is mostly invisible to privileged group members (Nicholson 2011). The ability to police essentialist others that are stripped of any mitigating identifying markers other than their criminal and transgressive status allows for simple, uncompromising messages about these others and the risks they pose. These invisible border controls are dependent on the increasing social exclusion of others who are represented as being devoid of any intersectionality (Harle 2000). They are not identifiable as individuals with a complex humanity but they are identified because of their differences. This allows the cooption of privileged Danish citizenry into a simply informed and self-policing panoptical observatory so that the transgressive others can be better identified by corralling them into the more easily observable excluded spaces defined by simple differences (Hanson 2009). The visualization of controls on a physical border is often intended not to be effective intervention against transgressive intrusion but visible 
representation intended to communicate the urgency and importance invested by the state in protecting Danes from others (Bigo 2000).

Overwhelmingly Danes no longer experience or see the actual border mechanisms and processes that exclude or constrain non-Danes. While the non-Dane is often visible and even encountered within Denmark, the bordering of non-Danes is not so easily discernible to those who have no experience of its most constraining processes.

What Danes do occasionally see are laws and practices that are staged on their physical borders to reassure them that they are being protected from terrorists and criminals. The separate processing of different nationalities at borders allows Danes to view non-Danes undergoing substantial scrutiny, as Danes pass quickly through privileged filters. Large signage is often placed above processing centres announcing "BORDER" and the processing area is covered with warning notices explaining how increased scrutiny at the border may delay or inconvenience Danish citizens while ensuring their greater personal security.

The purpose of borders is overwhelmingly presented to Danes as the means and places where interlopers are to be banned and prevented from illegally accessing Denmark. These interlopers are regarded as criminals who seek to illicitly dispossess the Danes of hard-earned securities and social benefits that are the rewards of a well ordered, market-oriented, competent democracy. Often cultural homogeneity is also added to the mix of qualifying attributes that allow Denmark to prosper and so borders are also used to protect notions of homogeneity. The privileges of free movement within the Danish/European Community have focused exclusionary borders on non-European/non-Danish migrants and the physical policing of exclusionary borders has mostly moved to the peripheries of the European Community (Shields 2009).

The construction of a threatening and undeserving other that needs to be dehumanized as an inherent illegal persona is central to the justification for these excluding borders. The diseased, the terrorist and, most threatening, the economic migrant have become the clear and present danger to the health, security and economic well-being of the privileged citizenry (Fanon 1967, Harle 2000). The desire of others to be healthy, safe and decently paid is the wicked motivation for what has been declared to be a vast international criminal enterprise (Nicholson 2011). This criminal enterprise is now considered to threaten the daily well-being of those who actually believe they deserve their privileged considerations and it is well understood by Denmark that these privileges can 
only be sustained by denying them to others (Agnew and Corbridge 1995, Bigo and Guild 2005).

Therefore others are clearly criminal in that they are criminalized for who they are rather than what they do. Like previous others or bad neighbours such as "Blacks" and "Jews" the illegal migrant cannot live lawfully inside Denmark (Bigo 2000). Depending which Denmark the illegal migrant is in they are criminalized in various ways. If an illegal migrant owns a car he cannot insure the car because he is an illegal migrant, he cannot have a driving license or a bank account because he is an illegal migrant, he cannot borrow a book from a library or see a doctor or a dentist (Laitinen 2001). The illegal migrant cannot rent an apartment or marry nor can their children legally attend school. Renting an apartment or assisting such a person is also criminalized in many places so actual human interaction or social intercourse with illegal migrants is a means of criminal contagion (Guild and Bigo 2010).

However while the exclusionary border is often interrogated and exposed to criticism, it is the often unnoticed and distant constraining border that most effectively prevents the non-Dane from acquiring Danish privileges (Guild and Bigo 2010). The institutional and other arrangements that prevent people from leaving a subjugated geography are the most efficient at perpetuating Danish privilege. The very poor are the least likely to move as they are unable to pay the documentation or transportation costs required to migrate, so poverty is the overwhelming constraining border control for most non-Danes (Skeldon 2003). The less educated and less skilled, who are usually the inexperienced young are excluded from entering most developed labour markets by denial of visas, so they are kept in the subjugated geography as cheap, disposable labour. Even skilled labour and highly skilled labour is being subjected to new Gastarbeiter regulations intended to ensure their eventual return to their places of origin (Guild and Bigo 2010).

The contrived dichotomy of the aged Dane versus the young African is a flawed and false dichotomy, as many others cross borders who are non-aged Danes and who are not young Africans. The young African could so easily be any excluded non-Dane when viewed from above. It matters little to the Dane if the non-Dane is African, South American or whatever; it is their identification as non-Danish that is essential. However trying to articulate the subtleties and nuances of a more specific identity such as the young African from below might be confusing but 
it allows for disambiguation from non-Danes and most Africans with Danish-like characteristics.

If you are non-Danish but mostly experience borders like a Dane you will probably have Danish attributes such as naturalized Danish citizenship or residency, higher education, wealth or exceptional skills. If you mostly experience borders in a similar way to a young African then you are probably non-Danish. However these intermediate or hybrid classes are not the subject of this investigation, even though many are important agents for sustaining the pre-eminence of Danish myths.

\section{Alternatives to Denmark: unconstrained geography as anarchy}

Since 1994 South Africa has been trying to develop a new foreign policy that allows it to more critically consider its relationship with the Danish nations. If the apartheid notions of neighbourliness are being reproduced in Danish border mechanisms in Africa that militate against the ability of South Africans to freely transact in international labour markets then there should be a presumption against sustaining such borders. That these borders might offer some advantage to South Africa by allowing it to exploit other constrained African labour (Landau and Segatti 2011) before the majority of the advantage accrues to Denmark will be a small compensation for the cost of operating the borders on behalf of Denmark. Constraining borders do not protect South Africa from intrusion and they distort the international and international labour market overwhelmingly to the disadvantage of youthful South Africa.

In dismantling the legacy of apartheid, activists have identified privileged control over land and various commodities as the legitimate target for transformation and reconstruction. However the institutionalized operation of constraining borders has not been the subject of such demanding calls for radical transformation. If Verwoerd's practice of using borders to increasingly constrain people into accepting serfdom is to be rejected, then South Africa must reject and dismantle such borders between it and its regional neighbours and increasingly examine how it can dismantle the mechanics of apartheid elsewhere. Although South Africa has ratified the SADC Protocol on the Facilitation of Movement of Persons in Southern Africa, it is often viewed as resisting the free movement of people in South Africa (John and Crush 2001). However, South Africa is experiencing increasing porosity of the region's borders 
as hundreds of thousands of undocumented people cross into the country with disregard for any border and suggesting that this mobility is irresistible (Landau and Segatti 2011).

Freer movement in Southern Africa will pose challenges but it will also present significant opportunities for a more efficient labour market where jobs and livelihoods can be better transacted by everyone. Freer movement is not a panacea for the structural problems of the South African economy and its labour market. However the development of an economy increasingly controlled by self-governing labour associations that are transnational and able to engage effectively with multinational capitalists will afford increasing opportunities to maximize benefits from extractive industries.

The benefits of a properly free and accessible labour market will be accentuated by the demography of Denmark. Aging and declining Danish populations will have to increasingly turn to young non-Danes to sustain their economies. Young people will need to reject being co-opted into societies that are currently planning how to use them and then cast them aside when they are no longer needed. Instead, organized labour in Africa needs to anticipate this demographic window and seek for labour to be allowed to move and associate freely across previous borders. Consequently there is an economic and moral imperative in dismantling the legacy of constraining borders that still sustain undeserved apartheid type privilege.

This change will allow the possibility of political and economic realignment and linkages from Denmark to Africa that are equitable and beneficial to the majority rather than a few. If liberal democracies are unable to equitably accommodate the needs of the previously repressed in the ensuing confusion that accompanies such radical change, then other systems of government will be need to be considered. The communism of the previous century failed to protect labour from the state, liberal democracy has failed to protect labour from the capitalist, and therefore it may be time for African non-state systems of government to be implemented so transnational linkages are instituted that allow labour to govern itself equitably across previous borders. Pre-colonial Africa was a centre of successful non-state, decentralized anarchies (Bratton 1989). If an African anarchy as a non-state system of non-violent self-associations supported by self-governing workers could equitably engage with or replace Denmark then this would offer the means to subvert the entrenched power of Denmark that is dependent on con- 
strained geography and subaltern states. If anarchistic non-state alternatives to Denmark offer the end of geography through dismantled borders, rational labour markets and equitable self-governance then such a society will clearly demonstrate that history has a life after Denmark.

\section{References}

Abel, A B, und D B Bernheim. 1991. "Fiscal Policy with Impure Intergenerational Altruism." Journal of Political Economy: 1687-1711.

Acemoglu, D. 1995. "Public Policy in a Model of Long-Term Unemployment." Economica 62 (1995): 161-178.

Agnew, John. 1998. Geopolitics: Re-Visioning World Politics. London: Routledge.

Agnew, John, und Stuart Corbridge. 1995. Mastering Space: Hegemony, Territory and International Political Economy. London: Routledge.

Arrow, K J, und G Debreu. "Existence of an equilibrium for a competitive economy." Econometrica 22 (1954): 265-290.

Arrow, K. 1972. “The Theory of Discrimination." In Discrimination on Labor Markets, Herausgeber: O Ashenfelter und A Rees. Princeton University Press, 1972.

Arthur, Chris. 1983. "Hegel's Master-Slave Dialectic and a Myth of Marxology." New Left Review, November-December 1983: 1-42.

Arxer, Steven. 2008. "Addressing postmodern concerns on the border: globalization, the nation-state, hybridity, and social change." Tamara 7, Nr. 7.2 (2008): 179-199.

Banerjee, A, und A Newman. 1993. "Occupational Choice and the Process of Development." Journal of Political Economy 101 (1993): 274-299.

Bigo, Didier. 2000. "Border Regimes and Security in an Enlarged European Community Police Co-operation with CEECs: Between Trust and Obligation". Working Papers of the Robert Schuman Centre.

Bigo, Didier, und Elspeth Guild. 2005 Controlling frontiers: free movement into and within Europe. Ashgate Pub Limited.

Bratton, Michael. 1989. "Beyond the State: Civil Society and Associational Life in Africa." World Politics 41 (1989): 407-430.

Cameron, D. 2011. "David Cameron immigration speech in full." Politics.co.uk. London, 10. October 2011.

Cohen, G A. 1983. "The Structure of Proletarian Unfreedom.” Philosophy and Public Affairs (Princeton University Press) 12, Nr. 1 (1983): 3-33.

Cooper, William. 2010. Borders stop socialism... The American Dream depends on keeping out cheap exploitable labour. http://www.youtube.com/watch?v=LGzTC6Qjyqw (Zugriff am 2. March 2013).

Davies, John. 2007. "Imagining better migration policy as a solution to irrational policy making." In Innovative Concepts for Alternative Migration Policies, von M Jandl. Amsterdam: Imiscoe.

Durlauf, S. 1996. “A Theory of Persistent Income Inequality." Journal of Economic Growth 1 (1996): 75-93.

Elster, Jon. 1979. Ulysses and the Sirens : studies in rationality and irrationality. New York: Cambridge University Press.

Fanon, Frantz. 1967. Black Skin, White Masks. New York: Grove Press. 
Ferreira, Francisco. 2013. "Can we increase mobility by reducing inequality?" London: The Economist, 2013.

Foucault, Michel. 1977. Discipline and Punish. Knopf Doubleday Publishing Group.

Fukuyama, Francis. 2004. State Building: A New Agenda. Cornell University Press.

Fukuyama, Francis. 2004. State building: Governance and world order in the 21st Century. Ithaca: Cornell Univesity Press.

Fukuyama, Francis. 2011. "Fukuyama warns of Neopotism.” The Business Report, 31st. October 2011: 22.

Fukuyama, Francis. 1992. The End of History and the Last Man. Free Press, 1992.

Fukuyama, Francis. 2004. "The Imperative of State Building." Journal of Democracy 15, Nr. 2: 17-31.

Guild, Elspeth, und Didier Bigo. 2010. "The Transformation of European Border Controls." In Extraterritorial Immigration Control: Legal Challenges, von Brian Ryan und Valsamis Mitsilegas, 257-280. Brill, 2010.

Hanson, Kenneth. 2009. "Postmodern Border Insecurity: Rationality, Discourse, and Antiessentialism." Administrative Theory and Praxis 31, Nr. 3 (2009).

Harle, Vilho. 2000. The Enemy with a Thousand Faces: the Tradition of the Other in Western Political Thought and History. Connecticut: Praeger.

Hegel, G. 1977. Phenomenology of Spirit. Übersetzung: translated by A.V. Miller with analysis of the text and foreword by J. N. Findlay. Oxford: Clarendon Press.

Johnson, Lauren. 2012. "Getting old after getting rich: comparing China with Japan." East Asia Forum, 22. December 2012.

Kojeve, Alexandre, Byran Frost, und Robert Howse. 2007. Outline of a Phenomenology of Right. Herausgeber: Alexandre Kojeve und Bryan Frost. Rowman \& Littlefield.

Kolossov, Vladimir. 2005. "Border Studies: Changing Perspectives and Theoretical Approaches.” Geopolitics (Routledge) 10 (2005): 606-632.

Laitinen, Kari. 2001. "Reflecting the Security Border in the Post-Cold War Context." International Journal of Peace Studies 6, Nr. 2 (2001).

Lindberg, Tod. "Getting to Denmark." Azure, 2005: 154-160.

Long, Jason. 2013. "Immobility is persistent, but perhaps not inevitable." The Economist. London.

Nicholson, Eleanor Taylor. 2011. Cutting off the Flow: Extraterritorial Controls to Prevent Migration. Berkley: Berkeley Law University of California.

Salter, David. 1992. "Theories of Development and Politics of the Post-modern - Exploring a Border Zone." Development and Change (Sage) 23, Nr. 3 (1992): 283-319.

Sen, Amartya. Development as Freedom. Oxford: Oxford University Press, 1999.

Shakespere, William. 1992. Hamlet. London: Wordsworth Editions.

Shields, P. 2009. Surveillance, information technology, and reconfiguring borders." Peace Review 21(3), 385-394. 21, Nr. 3 (2009): 385-394.

Skeldon, Ron. 2003. "Migration and Poverty." African Migration and Urbanization in Comparative Perspective. Johannesburg: Wits University Press.

Solon, Gary. "Intergenerational mobility in the labor market." In Handbook of Labor Economics, 1761-1800. Elsevier, 1999.

Spivak, C G. "Diasporas old and new: Women in the Transnational World." Textual practice 10, Nr. 2 (1996): 245-69.

Van Munster, R. 2009. The politics of risk in the European Union: Securitizing immigration. Basingstoke: Palgrave.

Welsh, Frank. 2000. History of South Africa. Harper Collins. 


\section{CORPORATE SOCIAL RESPONSIBILITY IN AFRICA: NEW TRENDS FOR DEVELOPMENT? A NEW FIELD FOR AFRICAN STUDIES?}

\section{Virginie Tallio}

Though development is a concept that comes from colonial times, the Marshall Plan is normally considered its milestone. Over the decades, it was shaped according to dominant economic doctrines. State intervention was considered crucial after the independences. During twenty years, the present international regime of aid development has been implemented, among others through the creation of essential institutions such as the United Nations Development Program (UNDP), the International Association for Development (IAD) or the Development Assistance Committee (DAC) of the Organisation for Economic Co-operation and Development (OECD). The belief that development was fuelled by the economic growth conducted to massive investments in infrastructure. This dogma was questioned in the 1970s. Economic growth was then considered as having to sustain essential needs of the populations (Thérien 2001). Then, the structural adjustment plans implemented by international financial institutions (International Monetary Fund and World Bank) in the 1980s encouraged the liberalization of the economy (Rist 1996). Facing their failures, human development is a concept that has shaped development goals since the 1990s. It defines the impact on people at the centre of the design of development policies.

The dynamics of development aid have been changing for a few years for two main reasons. Africa has been affected first and foremost by these changes as it is the main recipient of development aid (Hudson Institute 2011). First, the economic crisis has badly hit the development aid budgets of ODA (Official Development Assistance) donors. Public aid has remained steady since $2008^{1}$ and is unlikely to increase, due to the economic crisis (Hudson Institute 2011). Second, new actors have emerged and changed relations in the development arena, especially among classical actors, i.e. governments, local and international NGOs, faith-based organizations and local adminis-

\footnotetext{
${ }^{1}$ Source: Organisation for Economic Co-operation and Development, www.oecd.org.
} 
tration. The participation of so-called emerging countries, especially BRICS (Brazil, Russia, India, China and South Africa), has been stepped up and new forms of cooperation have been established between states (OECD 2011). At the same time, after a decrease in 2008 because of the crisis, private aid has increased since 2009 and has gone mainly to Africa (Hudson Institute 2011). This goes hand in hand with a diversification of actors. Private-public partnerships (PPP) are more and more important in development funding. In 2011, one of them, the Global Fund to fight AIDS, Tuberculosis and Malaria, appeared among the top ten of ODA donors for Africa (OECD 2013). Some philanthropic foundations now have more financial capacity than some governments or international agencies. The Bill and Melinda Gates Foundation allocates almost as much money to health programmes as the United Nations World Health Organization $^{2}$. Private flows are difficult to amount. As an example, in 2009, USA private philantrophy reached 37.5 billions dollars compared to 28,8 for ODA. Corporations gave 8,9 billions dollars, and 49\% went to sub-Saharan Africa, foundations 4,6 billions (18\% for sub-Saharan Africa) and private and voluntary organizations 12 billions (33\% for sub-Saharan Africa). In all cases, sub-Saharan Africa was the biggest recipient (Hudson Institute 2011).

The private sector's rise to power in development aid is a well-established trend. It stems from the privatization of the economy, also a deep-rooted tendency. Enterprises' contribution to African development is often thought through business, investment or production and, indeed, Africa is a continent with exponential growth rates and economic potential to exploit (OECD 2011). It is the continent where business activities have the most positive or negative impact (Visser 2008). Indeed, its social and economic context favours the emergence of enterprises as development actors in several respects. This continent has a booming economy and offers juicy markets for companies, all the more with the consolidation of a middle class (Deloitte 2012) that is a breeding ground for potential consumers. Creation of jobs and technology transfers resulting from the establishment of industries also have positive impacts on national economies. In a more general perspective, it helps to end aid dependency. Simultaneously, Africa is still severely struck by impoverishment and needs for poverty reduction and social equity are huge. Environmental protection

\footnotetext{
${ }^{2}$ Source: Department for International Development, www.dfid.co.uk.
} 
is also an area where there is much to do. It is considered that setting up a solid industrial and commercial base should not be the only way for companies to participate in African development. Governments, African citizens and international public opinion think that they need to contribute actively and directly to African development in order to "earn their "licence to operate" (Forstater et al 2010). In that respect, their action in the name of corporate social responsibility (CSR) is becoming more and more prominent on the development scene. In this capacity, they can either fund projects that are implemented by development agencies or execute their own programmes.

CSR practices include programmes that are aimed at minimizing the harmful effects of their business on society by means of environmental protection programmes or community development projects and seek to emphasise the positive effects of their business on their input (staff safety and ethical business conduct). Practices labelled as CSR have existed for a long time, although they were not called that (Crane et al 2007). Corporate social responsibility is mainly used but terms such as business ethics, corporate citizenship, corporate sustainability, etc are also common to describe the same thing. This concept is fluid and multifaceted. It has been regarded as the imposition of a Western concept, and thus Western values, which needs certain conditions to work in other contexts. Ideally, companies should act at an international level in democratic countries with active civil organizations (Baskin 2006). Some specificities of the African context have to be taken into account in order to implement functioning CSR strategies. The high level of corruption, weak states, the absence or poor labour legislation and social and/or political conditions in general diminish a company's performance and are likely to be found in most African countries. In that regard, some Western authors have tried to adapt the dominant definitions of CSR to the African context. The best known definition of CSR is in Carroll's theory. In his article "A Three-Dimensional Model of Corporate Performance", he defines four categories of CSR and later on depicts it as a pyramid (Carroll 1991). The base is the most important responsibilities that society expects from a company and the top is the least important. Originally, this pyramid was based on economic responsibilities, then legal ones, then ethic ones and philanthropic responsibilities were at the top of the pyramid. This means that first a company needs to make profits, then to follow the laws of the country in which it operates, 
then to do what is fair, just and right and eventually to contribute to society's quality of life. Visser proposed an alteration to this order in his paper "Revisiting Carroll's CSR Pyramid: An African Perspective". He upholds that the order of the different CSR components is not the same for Western firms and African firms. The order is different in developing countries. It is still grounded on economic responsibilities but philanthropic responsibilities are considered more important, legal responsibilities are third and the top of the pyramid is ethical responsibilities. The obligation to generate profits is still the main responsibility of an enterprise towards society. Then, it has to participate actively in improving its quality of life. Good relations with authorities come third. Lastly, it has to abide by codes of conduct guaranteeing ethics in business. (Visser 2006).

These efforts to integrate non-Western contexts into a definition of CSR are considered by many scholars to be interesting but not sufficient. It is now accepted more and more that this concept not only needs to take account of a wide diversity of contexts to be fully operational but also has its roots in non-Western traditions, including African ones such as communalism. African philosophical theories such as the African renaissance or Ubuntu also enable us to explore different facets of CSR not addressed in Western views (Dartey-Baah Amponsah-Tawiah 2011). The African renaissance was a concept first defined by Cheikh Anta Diop and then developed by Thabo Mbeki. It states that African problems can be solved by Africans using African solutions. Some of its values, such as sharing, commitment to the group, regard for compromise and consensus are essential in CSR. Ubuntu is the idea that we are human through others. It focuses on solidarity in the group, compassion, human dignity and a sense of community, which is also key in CSR. Nyerere's Tanzanian socialist state was built around the concept of Ujamaa (familyhood). It underlines the need for a development model based on African values (Rist 1996). As such, it could be considered as seeding the concept of CSR in Africa. The history of entrepreneurial intervention in Africa is also strongly linked to colonialism. Indeed, concession companies held rights to large parts of the colonized territory and ran them on behalf of the colonizer. They implemented different programmes to place the population under their yoke (Coquery-Vidrovitch 1972). CSR is then a concept that is historically and culturally rooted in Africa. 
Despite the clear embedding of CSR in the history of Africa and today's realities, the issue of its participation in the continent's development has been hardly touched by social sciences. Most of the academic literature is in the area of management, economics or business ethics. It mainly addresses CSR practices and policies (Barnes 2005, Crane et al 2007, Nelson 2004) without questioning the development model it proposes or its broader impact on the society. Another field of literature that deals with this issue is the grey one, i.e. produced by NGOs (non-governmental organizations) or think-tanks. It elaborates principally on businesses' legitimacy to operate on the development scene (Catholic Relief Services Karl 2003, Christian Aid 2004, Amundsen Wiig 2008) and accuses companies of laundering their image or buying social peace. Nonetheless, CSR is not only a business matter. It affects several areas commonly covered by social sciences: poverty reduction, education, public health, governance and the environment, along with different layers of society: government institutions, local administrations, civil society organizations and local populations. But it still has not earned its place as a research issue in the anthropology or sociology of development.

These have been two of the most prolific fields in African studies and have produced many books and articles. The development industry has been widely analyzed in recent decades. The logic underpinning it has been deconstructed (Ferguson 1994) and strategies in the field to identify partners and to adapt to them have been studied (Atlani-Duault 2005) and discourses and identities of donors and recipients have been analyzed (Baaz 2005). There has also been a vast critique of its failures (Edwards Hulme 1996, Escobar 1995, Fischer 1997, Igoe Kelsall 2005). Meanwhile, CSR policies and projects have not so far led to such large production. Few countries in Africa have been the target of this kind of research: South Africa, Côte d'Ivoire, Kenya and Nigeria mainly, and only from the perspective of agriculture, mining and petrochemical industries (Visser 2008). Development in Practice and Development are two journals that have published issues on the private sector's contribution to development, but none focused on Africa. CSR is often included in a more global approach to privatization of aid (Development in Practice 2005). Development specifically tackles CSR's contribution to development but also does not focus on Africa and only analyses it within the framework of opposition between NGOs and the private sector. This position is not fruitful and leaves 
out the numerous interactions between different players within the global development arena (Development 2004). Little has been written on the adaptation of NGOs to the business world and their influence on it (Nelson 2007).

This literature review shows that CSR programmes have not been investigated as such. Their inputs on development practices, policies and discourses have been set aside by African Studies academics, be they anthropologists, sociologists or political scientists, who could be the main contributors. They would contribute positively to the debate on the changes driven by the appearance of these actors on the development scene and the impact of these projects on the African society. Indeed, the consequences are not only at an economic level but also involve changes in different fields of African society. Anthropology of development, public health and political sciences are some of the disciplines that would shed a light on what is at stake under the common heading of "privatization of aid".

It is known that development projects lead to new discourses and practices in local and international NGOs, local administration, national government and civil society (Olivier de Sardan 1995). The role of international or local NGOs or other "classical" development actors (churches, local administrations, grass-root organizations, etc) is challenged by the appearance of these entities and has changed drastically. In most cases, the financial capacity of CSR departments is higher, they are better equipped in logistical terms and they have better relationships with the government because of their business activities. Moreover, they do not question its legitimacy or criticize its action as NGOs might do (Fassin 2007). In some countries, CSR departments have become essential development actors and their legitimacy is no longer needs to be proven.

The case of Angola is particularly illustrative of this situation. Most of the international NGOs have left the country or never entered it in the first place. The reasons are multiple. The cost of living is too high. Their budgets are reallocated to needier countries. Angola is considered to have enough resources to finance its own development. There is also a question of image for the Angolan government as it does not want to be considered a "developing country". The NGOs are not the ones handling the development market in financial or political terms. The oil companies' CSR departments are the usual interlocutors for NGOs and United Nations agencies looking for funding or imple- 
menting partners. This can be explained by several factors already mentioned above, such as the importance of the Angolan market as a growing economy or the change of the development paradigm. Furthermore, the Angolan government has implemented an Angolanization policy that forces oil companies to invest part of their profits in the social sector (Tallio forthcoming).

Companies' involvement in development issues has numerous consequences in the field. Firstly, relations between "classical" actors of development have changed. The status of NGOs is different as they are no longer the contracting authority but technicians that implement projects on behalf of the CSR departments. Work habitus is also rearranged, as entrepreneurial methods are imposed. Partners need to find new ways of reporting, defining their actions and proposing projects. Buzzwords differ. The emphasis is put on accountability and assessibility, i.e. measurable tools and no longer conceptual notions such as empowerment or capacity building (Cornwall 2007). This has an obvious impact on the way partners work and the way solutions are shaped.

Indeed, how businesses handle development issues rubs off on how development issues are defined. A striking example is the way public health could be deeply modified by intervention from the CSR sector. When we look at the types of projects funded by CSR, they do not seem very different from those funded by the NGOs. Both favour projects that target "vulnerable" groups such as women and children or programmes fighting the two diseases considered the main killers in Africa, HIV-AIDS and malaria. But there are, in fact, several shades of difference. Public health is not regarded as having to be accessible to everyone. The idea is that it is better to privilege some key-groups whose access to health care will eventually improve health indicators in a majority of the population by a domino effect. Women are especially targeted in this theory. Public health is seen as a set of diseases to fight via prevention and cure and in general as a set of statistics that need improving. A third group of projects is pretty new with regard to the usual public health projects. Highly technical projects that require expertise especially in the field of engineering are in the portfolios of these new project managers. They may involve maintenance of X-ray machines or the safety of the blood product chain. These kinds of projects were rarely handled by NGOs because of their technical nature. To favour some types of projects or to prefer certain ways of reporting 
does not only have effects on work habitus in the development sector but also deeply transforms some aspects of society.

This phenomenon goes hand in hand with another: CSR departments are becoming more professional. They used to be the poor relation within a company. Nowadays CSR is more and more important in a company's strategy. In some countries it is necessary to put on a show of social peace (Nigeria, Chad). It is a legal obligation in some countries (Angola, Mozambique). Now, development specialists are hired to evaluate projects for funding and implementation, draw up long-term strategies and build solid relations with the government and other interlocutors. Some of them go back and forth between them and NGOs, helping management models and development conceptions to move from one to another. The frontier between the "classical" actors of development and the private sector is blurred and the separation between these two components of aid will soon lose its relevance as an analytical tool.

Just like NGOs or faith-based charity organizations, CSR takes charge of areas that are supposed to be the state's prerogative. But they are not accountable for their actions to the citizens of the country where it takes place but rather to their stakeholders in CSR reports. This gives another dimension to research into the idea of the state that is still a prolific field in African studies. The company is considered in some CSR theories to be a corporate citizen and as such having to provide direct positive inputs to society. How will this idea be incorporated into an African theory of the state? The issue of privatization of the state, also a hot topic in African studies, is thus gaining new significance.

In order to answer these lines of research, investigation needs to be conducted on national and local levels. It will indicate how the CSR concept is appropriated by governments, companies and citizens. A comparison on a regional or a sectoral basis may also offer productive insights to help define CSR as an African product. Similarities and discrepancies between countries and political or economic contexts may also shed light on the specificities of CSR in an African context. Eventually, it would be interesting to compare African conceptions and practices of CSR with those in Asia or Latin America. Indeed, CSR implementers, i.e. CSR managers, may stay in the same company but take positions in different countries, not always on the same continent. They bring with them ideas, practices and concepts that travel from one place to another. Finally, this topic can help to develop an anthro- 
pology of business in Africa, a field that has been under-investigated until now.

To sum up, companies are now major actors in development. They act not only through their core activities but also their CSR policies. Though often described as being a Western concept, CSR has its roots in cultural and social contexts. African studies can provide insightful results on the changes it involves in African societies. They can also explain what the African context can bring to this concept and these practices. African studies will benefit from handling such research issues, just as classical CSR theoreticians, such as economists or management researchers, will profit from the insights of African studies to refine their theories.

\section{References}

Atlani-Duault, Laetitia. 2005. Au bonheur des autres. Anthropologie de l'aide humanitaire. Paris: Armand Colin.

Baaz, Maria Eriksson. 2005. The paternalism of partnership. A postcolonial reading of identity in development aid. London. New-York: Zed books

Barnes, Sandra T. 2005. "Global flows: terror, oil and strategic philanthropy" Review of African Political Economy 32(104): 235-252.

Baskin, Jeremy. 2006. "Corporate responsibility in emerging markets" Journal of Corporate Citizenship 24:29-47

Carroll, Archie B. 1979. "A Three-Dimensional Model of Corporate Performance". Academy of Management Review 4(4): 497-505.

Carroll, Archie B. 1991. "The Pyramid of Corporate Social Responsibility: Toward the Moral Management of Organizational Stakeholders”. Business Horizons 34:39-48.

Catholic Relief Service and Terry Lynne Karl. 2003. Bottom the barrel: Africa's oil boom and the poor. Catholic Relief Services.

Coquery-Vidrovitch, Catherine. 1972. Le Congo aux temps des companies concessionnaires. Paris: Mouton.

Cornwall, Andrea. 2007. "Buzzwords and fuzzwords: deconstructing development discourses” Development in Practice 17 (4-5):471-484.

Crane, Andrew and Dirk Matten, Laura J. Spence (eds). 2007. Corporate Social Responsibility. Readings and cases in a global context. London: Routledge.

Christian Aid. 2004. Behind the mask: the real face of corporate social responsibility. Christian Aid.

Dartey-Baah, Kwasi and Kwesi Amponsah-Tawiah. 2011. "Exploring the limits of Western Corporate Social Responsibility Theories in Africa" International Journal of Business and Social Science 2 (18): 126-137

Deloitte. 2012. The rise and rise of the African middle class, Deloitte.

Development 2004 Special issue 47(3)

Development in Practice 2005 Special issue 15 (3-4) "Private sector"

Edwards, Michael, and David Hulme. 1996. Beyond the magic bullet: NGO performance and accountability in the post-war world. West Hartford: Kumarian Press. 
Escobar, Arturo. 1995. Encountering development. The making and unmaking of the third world. Princeton: Princeton University Presse.

Fassin, Didier. 2007. "Humanitarism: a nongovernmental government" in Nongovernmental politics, edited by Michel Feher, 149-159. New-York: Zed books

Ferguson, James. 1994. The anti-politics machine. Development, depolitization and bureaucratic power in Lesotho. Minneapolis, London: University of Minnesota Press.

Fischer, William. 1997. "Doing good? the politics and antipolitics of NGO practices" Annual Review of Anthropology 26:439-464

Forstater, Maya and Simon Zadek, Yang Yu Guang, George Kelly, Xiao Chen Hong, Mark George 2010 "Corporate responsibility in African development: insights from an emerging dialogue" Corporate Social Responsibility Initiative, Working paper 60, Cambridge: John F. Kennedy School of Government.

Hudson Institute. 2011. Index of Global Philanthropy and Remittances available at http://www.hudson.org/files/documents/2011\%20Index\%20of\%20Global\%20 Philanthropy\%20and\%20Remittances\%20downloadable\%20version.pdf

Hugon, Philippe. 1993. Léconomie de l'Afrique. Paris: La Découverte.

Igoe, Jim and Tim Kelsall (eds). 2005. Between a rock and a hard place. African NGOs, donors and the State. Durham: Carolina Academic Press.

Nelson, Jane. 2004. "The public role of private enterprise. Risks, opportunities and new models of engagement" Corporate Social Responsibility Initiative, Working paper 1, Cambridge: John F. Kennedy School of Government.

Nelson, Jane. 2007 "The operation of non-governmental organizations (NGOs) in a world of corporate and other codes of conduct" Corporate Social Responsibility Initiative, Working paper 34 Cambridge: John F. Kennedy School of Government.

OCDE, 2011, Perspectives économiques en Afrique. L'Afrique et ses partenaires émergents. Paris: O.C.D.E.. doi : 10.1787/aeo-2011-fr Accessed 16 March 2013

OCDE, 2013, Development at a glance, 2. Africa. Paris: O.C.D.E. available at http:// www.oecd.org/dac/stats/Africa\%20-\%20Development\%20Aid\%20at\%20a\%20 Glance\%202013.pdf Accessed 16 March 2013

Rist, Gilbert. 1996. Le développement, histoire d'une croyance occidentale. Paris: Presses de Sciences Po.

Tallio, Virginie. forthcoming. "Os projetos de responsabilidade social das empresas petrolíferas em Angola: Que projeto para a saúde pública?” in Género e Pluralismo Terapêutico - Acesso das Mulheres ao Sector de Saúde Privado em África, edited by Clara Carvalho, Lisboa: Medina

Visser, Wayne. 2006. "Revisiting Carroll's CSR Pyramid: An African Perspective" In Corporate Citizenship in Developing Countries. New partnership perspectives, edited by Esben R. Pedersen and Mahad Huniche. Copenhagen: Copenhagen Business School Press.

Visser, Wayne. 2008. "Corporate Social Responsibility in Developing Countries” In The Oxford Handbook of Corporate Social Responsibility, edited by Andrew Crane, Abagail McWilliams, Dirk Matten, Jeremy Moon \& Donald Siegel, 473-479. Oxford: Oxford University. 


\title{
AFRICA'S DEMOGRAPHICS: A THREAT OR A BONUS?
}

\author{
Ana Pires de Carvalho
}

\section{Introduction}

Africa's population is growing at 2.4 per cent $^{1}$ per year, twice the rate of other regions in the world, and will double in around 30 years. The reason for this fast population increase is the rapid decline in infant and child mortality rates, whilst fertility levels are decreasing at a much slower pace, still remaining very high. Today's African women bear 5.0 children on average during their life time.

In the 1960s and 1970s there was a great concern about rapid population growth in most countries in the world and its effects on development. As a consequence, large-scale family planning programmes were set up, but excesses in populous China and India scaled down financial support for family planning. In the 1990s the appearance and quick spread of the HIV/AIDS pandemic, definitively diverted this support, as the human costs that this pandemic brought to millions of people made it necessary to redefine financing priorities. Furthermore, the previously projected population increase was expected to be reversed by this pandemic. However, in fact HIV/AIDS has not fundamentally changed the demographic equation. And for the first time in about two decades, the UN Population Division estimates that not one single African country will experience negative population growth due to HIV/AIDS. ${ }^{2}$

Many of the African elites have had the perception that rapid population growth is not an issue because of the vastness of Africa, low population densities and abundance of resources. ${ }^{3}$ In addition, a large number of children traditionally represented a family's importance and wealth. Children worked on the farm, and the family represented a small enter-

${ }^{1}$ United Nations Population Fund (UNFPA). 2012. The State of The World Population 2012:by Choice, not by Chance. UNFPA, New York, pp 114

${ }^{2}$ Sippel, Lilli; Kiziak, Tanja; Woellert, Franziska and Klingholz, Reiner. 2011. Africa’s Demographic Challenges: How a Young Population Can Make Development Possible. Berlin: Berlin Institute for Population and Development, pp. 4-8 and 12-16.

3 May, John. April 2008. http://web.worldbank.org/WBSITE/EXTERNAL/ COUNTRIES/AFRICAEXT/0,,contentMDK:21709116 pagePK:146736 piPK:226340 theSitePK:258644,00.html (visited 27 February 2013). 
prise where size directly correlated with output. In fact, in a subsistence agrarian economy and with no limits of access to land, high levels of fertility are economically attractive. When the predominantly agrarian subsistence economy evolves to an industrialized, technologically more advanced economy ${ }^{4}$ there is a value associated with children (costs of education, health and others) and the strategy of having many children is no longer efficient. This technical progress also comes with a decrease in mortality rates, in particular child mortality, but parents still fear the capricious inroads of mortality. While these mortality declines are substantial, parents still think that many children die, because it is true, even though for the last decades child's mortality levels have more than halved. ${ }^{5}$ Responses and behavioural adaptations are delayed, as it takes time for parents to realize this decrease and for a while they continue to think that they have to have many children. ${ }^{6}$ However, in any case, it is clear that the premise of having land without limits no longer exists for most of African rural areas.

Rapid population growth contributes to poverty at family level, by straining the family's budget and reducing available resources to feed,

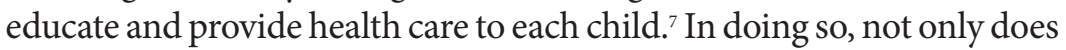
it increase the number of poor but also the percentage of poor. Indeed, taking into account that on average a poor family has more children than a rich family, if poor people continue to be poor and rich people continue to be rich then in the next generation not only will the number of poor people increase, but the relative percentage of poor will also rise. This is a simplified model, but it is important to take it into account.

Rapid population growth puts a lot of stress on ecosystems, specifically on food production and consequently food security, land and more generally environmental degradation and water supply. ${ }^{8}$ Rapid population growth impacts on economies in different ways, but the slow-down of the increase in per capita income is the most evident

\footnotetext{
${ }^{4}$ Becker, Gary S. and Barro, Robert J. 1988. "A Reformulation of the Economic theory of Fertility." The Quarterly Journal of Economics, Vol.CIII, February 1988, Issue 1. USA, pp.1-3.

${ }^{5}$ United Nations Children Fund (UNICEF). 2012. The State of the World Children 2012. UNICEF, New York, pp. 83-137.

${ }^{6}$ Carvalho, A. 2005. "Mortality Perceptions and their Influence in Fertility Desires." PhD diss. University of Southampton, UK. (Carvalho, 2005), pp.226-237.

${ }^{7}$ Birdsall, Nancy. 1994. "Government, Population, and Poverty: Win-Win Tale." In Population and Development: Old Debates, New Conclusions", Transaction Publishers, New Brunswick (USA) and Oxford (UK), 1994, Ch.9.

${ }^{8}$ Alex Evans, 2009 "The Feeding of the Nine Billion, Global Food Security for the 21st Century" Chatham House, Royal Institute of International Affairs, UK, pp.6-10.
} 
consequence. Moreover, health and education systems are stressed out and millions of young people are unemployed, even outside the informal labour market. Cities will be over-populated both by natural increase and migration from rural areas. Furthermore, attempting to provide capital investments for their population, governments will decrease investment in infrastructures and industry. Rapid population growth, associated with high fertility, represents a threat to women and children's health and increases mortality rates because women have too many babies too early and too late. ${ }^{9}$

The way to the demographic dividend is open to African states. Indeed, if conditions for a decrease in fertility are created and the right course for education and employment is set, the prospects of today's poorest countries would significantly improve. It's important to point out that a decrease in fertility will not guarantee socioeconomic development, as it is impossible to fully achieve the demographic dividend in a country with poor education, high unemployment rates and even violence. Nevertheless, improvements in education alone will not be enough for considerable improvement. ${ }^{10}$

The study that follows elaborates on these issues and stresses the importance of immediate action, before the demographic dividend opportunity is missed. It gives an overall view of the issues related to population dynamics and development, and point out the most important and sometimes complex linkages. Most data used in this study are taken from United Nations Secretariat and United Nations Agencies published documents.

\section{Rapid population growth and youth employment}

Data on employment and unemployment in Africa is rare, imprecise, and estimates from various United Nations organizations can sometimes differ significantly. Even rarer are breakdowns of unemployment rates by age, which are needed to estimate youth unemployment. The reason for this lack of accurate data on employment/unemployment is the existence of a sizeable informal sector in the African economies that is difficult to measure or even estimate. However, any analysis

\footnotetext{
9 http://www.unicef.org/about/history/files/sourcebook_children_1990s_part3. pdf, pp 89, visited 5 March 2013.

${ }^{10}$ Sippel, Lilli; Kiziak, Tanja; Woellert, Franziska and Klingholz, Reiner. 2011. Africa's Demographic Challenges: How a Young Population Can Make Development Possible. Berlin: Berlin Institute for Population and Development, pp. 55-72.
} 
considering only the formal sector would be incomplete, even erroneous as it would include only a part of a country's economic activity.

The International Labour Organization (ILO), cited in United Nations Development Program (UNDP), ${ }^{11}$ gives a glimpse of the existing data. The employment to population ratio (proportion of working age population aged 15 and older who are in employment) in sub-Saharan Africa is around 65 per cent and this rate has not changed significantly for the past 20 years. However, this employment figure includes 'vulnerable employment', i.e. the sum of own-account workers and unpaid family workers. The ratio of vulnerable employment to total employment in Africa was 76 per cent in 2009. This percentage was a slight improvement on 1988, when it was 80 per cent but, due to population increases, the number of people engaged in vulnerable employment rose by 7.4 million. In addition, women are even more vulnerable than men as, when broken down by gender the figure is 84 per cent for women and 70 per cent for men. While there is no breakdown by age, young people seem to suffer more from unemployment than older people.

One conclusion from these figures is that for the twenty years between 1988 and 2009 many more people worked in the formal sector, which represents an effort by African governments to provide employment. Indeed, the number of employed people rose with population increases, keeping employment percentages more or less constant. However, under these circumstances, the number of people outside the formal sector and even outside any economic activity also rose substantially.

Table 1 shows population increases and youth population increases in sub-Saharan Africa from 2010 to 2025. In 2025 there will be approximately 358 million more people in this region than there were in 2010. In addition, for the same period of time, it is estimated that part of this increase will be of people aged 15-34, totalling around 230 million. Applying the above employment rates, many more people, particularly young people, are expected to be outside the workforce in 2025. At these rates, the number of people, particularly unemployed youth, will be much larger in years to come.

${ }^{11}$ United Nations Development Program (UNDP), 2011 Assessing progress in Africa toward the Millennium Development Goals. UNDP, New York, pp.11-17. 
Table 1 People aged 15-24, 15-34 and total population in sub-Saharan Africa, 2010-2025

\begin{tabular}{|c|c|c|c|}
\hline Year & $\mathbf{1 5 - 2 4}$ years & $\mathbf{1 5 - 3 4}$ years & $\begin{array}{c}\text { Total popu- } \\
\text { lation }\end{array}$ \\
\hline 2010 & 172,010 & 296,104 & 853,564 \\
\hline 2015 & 192,683 & 336,042 & 963,752 \\
\hline 2020 & 217,084 & 380,025 & $1,084,318$ \\
\hline 2025 & 242,628 & 426,053 & $1,212,135$ \\
\hline \multicolumn{4}{|c}{ Source: World Bank data from $^{12}$} \\
\end{tabular}

Investing in youth, particularly through labor intensive programmes, is a crucial strategy for transforming the demographic challenge into economic opportunities, social inclusion and poverty reduction.

Perhaps ironically, child labour in sub-Saharan Africa is very high, as 32 per cent of children aged 5 to 14 are economically active ${ }^{13}$. Besides the ethical aspects linked to this, the high levels of child labour mean that a considerable proportion of families still favour large families, thus creating a vicious circle.

\section{Rapid population growth and urbanization}

In a recent interview at the Woodrow Wilson School, Princeton University, Eliya Zulu ${ }^{14}$ from AFIDEP (African Institute for Development Policy), stated that rapid urbanization is one of Africa's biggest challenges. Indeed, as he said, "Africa is the least urbanized region of the world now, but it's growing at the highest rate ... If the economies are not going to develop the capacity to absorb this population and create enough jobs for them, there's going to be chaos, because you can't have all these young people without having jobs for them."

Over the centuries, urbanization has constituted a driving force in the creation of wealth and the organization of work is now more effi-

${ }^{12}$ http://web.worldbank.org/WBSITE/EXTERNAL/TOPICS/EXTHEALTHNUTRITIONANDPOPULATION/EXTDATASTATISTICSHNP/EXTHNPSTATS/0,,contentMDK:21737699 menuPK:3385623 pagePK:64168445 piPK:64168309 theSitePK:3237118 isCURL:Y,00.html, visited 5 March 2013

${ }^{13}$ United Nations Children Fund (UNICEF). 2012. The State of the World Children 2012. UNICEF, New York, pp.83-137.

${ }_{14}$ Zulu, Elya. 2011. http://www.newsecuritybeat.org/2011/02/eliya-zulu-on-population-growth-family-planning-and-urbanization-in-africa/, visited 27 February 2013. 
cient, transportation of people and goods is easier and cheaper, access to health and education services is more effective, innovation is more intense, investments in infrastructures benefit many people, and so on.

However, rapid population increase brings some burdens to the urbanization process. Indeed, not only is the excess of people in rural areas increasing enormously, along with migration to urban centres, but there is also the natural increase inside the cities themselves. Indeed, urban population increase in sub-Saharan Africa is more due to natural increases in urban residents than to migration. ${ }^{15}$ This is due to the fact that mortality rates in cities are generally much lower than in rural areas, with no proportional differential in fertility rates. However, migration from rural to urban areas is still an important part of cities' dramatic growth in sub-Saharan Africa.

From 1990 to 2010, the urban population in Africa grew from 146 million people to 321 million, ${ }^{16}$ i.e. it more than doubled in 20 years. In addition, there are some cities where the growth rate is even higher, such as Lilongwe, Nairobi or Abuja. However, much of the urban increase in sub-Saharan Africa is expected to take place in small towns

Existing infrastructures and sanitation in large cities cannot accommodate this population increase. For example only 44 per cent of urban people use proper sanitation facilities in sub-Saharan Africa. ${ }^{17}$ Even more worrisome is the absence of these facilities in areas that will soon become urban. In fact, only 24 per cent of the rural population have access to improved sanitation facilities.

Until recently, rural settlements in sub-Saharan Africa were the epicentre of poverty and human suffering. All poverty indicators, whether based on income, consumption or expenditure, show that rural poverty was deeper and more widespread than in cities. However, recent studies have suggested that urban populations are changing in many countries. For instance, a case study on Kenya indicated that urban under-five mortality had increased over time and, although urban rates are still lower than rural rates, poor urban children have higher mortality rates

${ }^{15}$ United Nations Population Fund (UNFPA). 2007. The State of The World Population 2007: Unleashing the Potential Urban Growth. UNFPA, New York, p. 10-15

16 United Nations Human Settlements Programme (UN-HABITAT). 2012. State of the World's Cities 2012-2013. UN-HABITAT, Nairobi, Kenya, p.126.

17 United Nations Children Fund (UNICEF). 2012. The State of the World Children 2012. UNICEF, New York, pp.83-137. 
than even their rural counterparts. ${ }^{18}$ The study attributed this partly to low access to health facilities and clean water and poor sanitation.

Poverty is now increasing more rapidly in urban areas than in rural areas, but has received far less attention..$^{19}$ The current concentration of poverty, slum growth and social disruption in cities does paint a threatening picture. For a large proportion of people sanitation is non-existent, epidemic diseases thrive, exploitation is rampant, unemployment is widespread and physical dangers lurk where law is absent and order may be left to criminal gangs. This increase of extreme poverty in the cities is often overlooked. Indeed, as cities accommodate the country's wealthiest people, extreme poverty is diluted in the overall statistics.

However, while cities concentrate poverty, they also still represent the best way to escape it. Cities are better able to take advantage of globalization's opportunities and generate jobs and income for a larger number of people. Cities are in a better position to provide education and health care as well as other services and amenities, simply because of their advantages of scale and proximity. In fact, managing urban growth has become one of the most important challenges of the 21 st century. ${ }^{20}$

There is an urgent need for policy-makers and civil society to understand and accept the demographic and social composition of urban growth. Empowered with this knowledge, these agents of development can take some basic approaches and initiatives. This could have a huge impact on the fate of poor people and on the viability of the cities themselves.

Urbanization processes and features deserve closer scrutiny. As mentioned above, in sub-Saharan Africa most of the urban increase is due to natural growth, i.e. births in excess of deaths. This means that urban-rural migration is not as significant, but there is a need to measure each of these components of urban growth as they can point to different development policies. Moreover, another important feature, is that at least half of the urbanization will take place in small and medium-sized cities. These small cities are still not prepared to accommodate large numbers of people in a short period of time. For instance, they lack

${ }^{18}$ Madise et al, 2007. "Progress Towards the Child Mortality Millennium Development Goal in Urban Sub-Saharan Africa: The Dynamics of Population Growth, immunization, and access to clean water" BMC Public Health 2007, 7:218.

${ }^{19}$ United Nations Population Fund (UNFPA). 2007. The State of The World Population 2007: Unleashing the Potential Urban Growth. UNFPA, New York, p. 10-15

${ }^{20}$ United Nations Human Settlements Programme (UN-HABITAT). 2012. State of the World's Cities 2012-2013. UN-HABITAT, Nairobi, Kenya, pp. 1-20. 
substantial infrastructures such as access to proper sanitation. Finally, a large proportion of urban growth, whether from migration or natural increases, is made up of the poor and extreme poor. ${ }^{21}$

A good indicator of these concerns is the increase in slums. According to the United Nations Human Settlements Fund (UN-Habitat), a "slum household" is a "group of individuals living under the same roof in an urban area who lack one or more of the following: durable housing, sufficient living area, access to improved water, access to sanitation and secure tenure." ${ }^{22}$ In other words, not all poor people live in slums and not all people who live in areas defined as slums are poor.

In sub-Saharan Africa, the proportion of people living in slums as defined above slightly but significantly decreased from 1990 to 2009, from 70 to 61 per cent (Table 2). Not surprisingly, however, the number of people living in slums increased considerably, from 103 to 198 million, i.e., it almost doubled in the same period.

Table 2 Proportion of urban people living in slums and total urban population living in slums, in sub-Saharan countries and selected countries, 1990, 2000 and 2009

\begin{tabular}{|c|c|c|c|c|c|c|}
\hline & \multicolumn{4}{|c|}{$\begin{array}{c}\text { Proportion of urban } \\
\text { people living in slums }\end{array}$} & \multicolumn{3}{c|}{ Total urban population living } \\
& 1990 & 2000 & 2009 & 1990 & 2000 & 2009 \\
\hline & $70 \%$ & $65 \%$ & $61 \%^{*}$ & 102,641 & 143,255 & 198,168 \\
\hline $\begin{array}{c}\text { Sub-Saharan } \\
\text { Africa }\end{array}$ & $88 \%$ & $92 \%$ & $96 \%$ & 943 & 1,296 & 1,642 \\
\hline $\begin{array}{c}\text { Dem. Rep. } \\
\text { Congo }\end{array}$ & $55 \%$ & $55 \%$ & $55 \%$ & 2,343 & 3,400 & 4,762 \\
\hline Kenya & $96 \%$ & $89 \%$ & $76 \%$ & 5,819 & 8,653 & 10,427 \\
\hline Ethiopia & $7 \%$ & $3.3 \%$ & $24 \%$ & 121 & 140 & 1,141 \\
\hline Zimbabwe & $76 \%$ & $78 \%$ & $80 \%$ & 2,161 & 4,381 & 6,940 \\
\hline Nigeria & $70 \%$ & $63 \%$ & 26,549 & 36,951 & 47,612 \\
\hline Mozambique & & & & & & \\
\hline
\end{tabular}

Source: data from UN-HABITAT

\footnotetext{
${ }^{21}$ United Nations Population Fund (UNFPA). 2007. The State of The World Population 2007: Unleashing the Potential Urban Growth. UNFPA, New York, p. 10-15

${ }^{22}$ United Nations Human Settlements Programme (UN-HABITAT). 2012. State of the World's Cities 2012-2013. UN-HABITAT, Nairobi, Kenya, pp. 123-125.
} 
Furthermore, while the proportion of people living in slums decreased on average, there are some countries in sub-Saharan Africa where not only the number of people living in slums increased, but also their proportion in total urban people (Table 2). That's the case in Mozambique, Zimbabwe and Democratic Republic of Congo . Interestingly, the proportions of people living in slums in Nigeria and Ethiopia have decreased significantly, though the number of people has increased drastically, suggesting a very high rate of population increase due to considerable rural-urban migration.

\section{Rapid population growth and education}

The most important effect of rapid population growth on education is the stress it places on school attendance and the quality of educational systems. Immediately after independence most African countries set up education systems aimed at universal schooling, at least at primary level. Nowadays, governments struggle hard to keep this universal schooling. Rapid population increase is part of the problem. Indeed, every year there are many more school-age children than in the previous year. Education systems have to manage this situation by increasing the number of schools, teachers, books etc. Often, when a country's revenues do not allow for an increase in the education budget, managers resort to other solutions such as increasing the number of children per class, reducing the number of hours in school and teaching classes under trees.

Indeed, net primary school attendance in sub-Saharan Africa is 67 per cent for boys and 65 per cent for girls, ${ }^{23}$ while the ratios for secondary schools are 31 per cent and 28 per cent. There are many examples of the problems mentioned above. Between 2005 and 2011 school attendance rose from 59 to 96 per cent in Burundi ${ }^{24}$ and the average number of students per class is estimated at 83. In Niger, Burkina and Mali more than half of young people aged 15-19 did not finish primary school. A large proportion of people aged 20-24 has no schooling at all (more than 50\% in Burkina Faso and Mali and over 30\% in Chad and Ethiopia). In general, girls' school enrolments are lower than boys', especially in the rural areas.

${ }^{23}$ United Nations Children Fund (UNICEF). 2012. The State of the World Children 2012. UNICEF, New York, pp.83-137.

${ }^{24} \mathrm{http} / / /$ www.un.org/africarenewal/magazine/august-2012/african-schools-keepeye-prize 
It is understandable that such conditions may exist for a short period, but the prospects are not very encouraging. Even if governments decide to increase the education budget considerably, they will do so at the expense of capital investments in infrastructures and industry. This will jeopardize countries' development in the future.

Education in Africa needs to be modernized and developed in accordance with the demand for manpower. Additional financial resources are needed to transform education systems, but this investment will be efficient only if the number of students does not increase at today's rate.

\section{Rapid population growth and health}

Health systems also suffer considerably from rapid population increase. High fertility means that more people will need to access care services than the year before. Particularly, there will be many more children than before as there are more mothers than there were the previous year. Particularly in rural areas there is a crucial shortage of health facilities. Rapid population growth also means that there is an increased demand for physicians, nurses and other service providers. Lack of prospects in the rural areas is assumed to lead to a swell in migration into urban areas.

Throughout Africa disease is a permanent spectre. Malaria and HIV/AIDS alone are responsible for one third of all deaths. Malaria is still the number-one cause of death. It kills indifferently at all ages, while HIV/AIDS is selective for prime-age adults, leaving their children behind.

Infant and under-five mortality rates have been decreasing since the 1970s, but they are still very high. In 1970 the under-five mortality rate was 234 deaths per 1,000 while in 2010 it was 121 . Infant mortality rates decreased from 105 per 1,000 in 1990 to 76 in 2010.

While this fall in mortality rates is taken as a good sign, levels are still unacceptably high. An under-five mortality rate of 121 per 1,000 means that one in every nine children does not reach the age of five. These high rates are also reflected in low life expectancy at birth which is 54 years on average. It is important to note that these are averages and that not every country has such rates. In fact, there are countries with much higher rates. For instance, Mali's under-five mortality rate is 178 per 1,000 , i.e. one out of 5.6 children does not reach the age of five. ${ }^{25}$

${ }^{25}$ United Nations Children Fund (UNICEF). 2012. The State of the World Children 2012. UNICEF, New York, pp.83-137. 
HIV/AIDS is still a disease that deserves special attention as it mainly affects prime-age adults. Not only do many people suffer and ultimately die, but the effect of reducing the workforce and leaving many orphans behind adds a special dimension to this disease. UNICEF estimates that there are around 55 million orphans in sub-Saharan Africa, a large proportion due to HIV/AIDS. However, family planning programmes and the advocacy and distribution of condoms could help curb the spread of this disease considerably.

Maternal mortality rates are high, as in every 100,000 births 640 women die of causes related to pregnancy and childbirth. This mortality ratio means that one in 31 women will die in her life time due to motherhood. The more children women bear, the greater the risk of mortality will be, hence maternal mortality rates will fall with decreases in fertility.

The high fertility levels associated with rapid population growth have specific effects on women's and children's health and wellbeing:

- Higher infant mortality rates (births from very young or very old mothers and frequent pregnancies increase the probability of infant death).

- Greater maternal mortality risk, because they have more children and are therefore more exposed to mortality and also because the risk of death is more likely in pregnancies in very young or very old women.

- More clandestine abortions and consequently higher associated mortality risks.

A good, widespread network of well-equipped health facilities run by well trained professional staff is the backbone of appropriate health services. However, as mentioned above, rapid population increase adds more people being served by this network every year, stretching its capacities more and more. For instance, skilled attendants at birth in rural areas are still very few and only 40 per cent of the births are attended by skilled health professionals such as doctors, nurses or midwives.

The provision of modern contraceptives by health services is still highly incipient. There are still a large number of unwanted births. Indeed, contraception is still only used by 23 per cent of women of childbearing age. If the provision of modern contraceptives works effectively and reaches all women and education on the benefits of family planning is provided, contraceptive prevalence could double in a very short 
time. Average contraceptive prevalence in Latin America is around 60 per cent.

Access to family planning services is a great tool of women's empowerment. If women exercise their right to have as many babies as they want, they will be free to participate more actively in economic activities and thus contribute more to society's well-being.

Furthermore, very early pregnancies are still very numerous throughout sub-Saharan Africa. There are 123 births per 1,000 adolescents aged 15-19 and 28 per cent of women aged 20-24 give birth before they are 18 years old ${ }^{26}$. These rates are due not only to low contraceptive prevalence, but also to social norms allowing very early marriages or unions. Indeed, 24 per cent of girls aged 15-19 are married or in a union. Moreover, starting childbearing at very young ages contributes strongly to high levels of fertility.

\section{Rapid population growth, environment and food security}

While enough food is produced worldwide, it is not always produced where it is needed. In countries with rapid population growth there are sparse yield increases from modern farming methods. As a result, sub-Saharan Africa countries today produce less food per capita than at any time since independence. ${ }^{27}$ One of the reasons is that farms are getting smaller as the population increases. Rapid population growth is outpacing sub-Saharan Africa's capacity to produce its own food. ${ }^{28}$ Food insecurity is widespread and at least 30 per cent of people are malnourished.

Food insecurity is tending to grow, as the lack of financial resources to buy cereals is becoming a constraint. Indeed, the already difficult acquisition of cereals is being exacerbated by the fact that cereals are more scarce and expensive in the world market. Not only is the world population growing in other parts of the world, but changes in many people's diet in emerging economies is also creating competition for cereals. It is urgent to implement some kind of green revolution, but financial resources are needed to do that.

${ }^{26}$ United Nations Children Fund (UNICEF). 2012. The State of the World Children 2012. UNICEF, New York, pp.83-137.

${ }^{27}$ Alex Evans, 2009 "The Feeding of the Nine Billion, Global Food Security for the 21st Century" Chatham House, Royal Institute of International Affairs, UK, pp.6-10.

28 Angelo, Victor. 2012. "Europe and Africa: From Indifference to Interdependence" Paper presented at the conference 'Building the Africa-Europe Partnership: What Next?', Fundação Calouste Gulbenkian, Lisbon, December 13-14. 
The Intergovernmental Panel on Climate Change (IPCC) thinks that Africa will be the continent hardest hit by the consequences of climate change. Experts think that large extensions of land will become dry, millions of people will be thirsty and livestock will suffer considerably. ${ }^{29}$ Alex Evans reports that the outlook for global food security over the coming decades will be characterized by turbulence, uncertainty and risk.

Furthermore, population pressure will inflate competition for other resources such as water and firewood.

\section{Rapid population growth and political strife}

It is well known through human history that high competition for scarce resources has often led to political instability and war. Rapid population growth without corresponding socio-economic development can exacerbate existing conflicts that might otherwise not be as significant. This includes disputes between countries, armed rebellions and civil conflicts. More and more scholars attribute part of the responsibility for recent conflicts, ${ }^{30}$ such as Rwanda, to rapid population growth..$^{31}$

Indeed, it is interesting to note that:

- In the 1960s and 1970s annual population growth in Rwanda was 3 per cent and had increased to almost 5 per cent by the end of the 1980s. Population increase at this level means that it doubles in 15 years. Rwanda's genocide occurred soon after the population growth rate peaked. ${ }^{32}$

- In Mali, the most recent large conflict in sub-Saharan Africa, the annual population growth rate between 1960 and 1990 was relative low, from 1.2 to 2.1 per cent. However, since then this rate has increased and since 2000 the population growth rate has been around 3 per cent.

\footnotetext{
${ }^{29}$ Sippel, Lilli; Kiziak, Tanja; Woellert, Franziska and Klingholz, Reiner. 2011. Africa's Demographic Challenges: How a Young Population Can Make Development Possible. Berlin: Berlin Institute for Population and Developmement, pp.12-16.

${ }^{30}$ Institute du Sahel, Centre d'Études et de Recherche sur la Population pour le Développement (CERPOD). 1990. Population et Développment dans le Sahel: les defis de la croissance rapide de la population. CERPOD, Bamako, Mali, (1990).

${ }^{31}$ King, M. 1996. The Population Wolf and Demographic Entrapment in Rwanda. American Journal of Public Health, 1996 Jul; 86(7): 1030-1.

32 http://www.google.com/publicdata/explore?ds=d5bncppjof8f9_\&met_y=sp_ pop_grow\&idim=country:RWA \&dl=en \&hl=en\&q=rwanda\%20population $\% 20$ growth\%20graph
} 
- The population growth rate in the Democratic Republic of Congo (DRC) was between 2.7 and 3 per cent a year from 1965 to 1985. Then it jumped and in 1992 reached its peak at 4.1 per cent3. Conflict in the DRC intensified in the mid-1990s.

Figure 1 Total fertility rate (TFR) in selected countries and subSaharan Africa average from 1960 to 2010

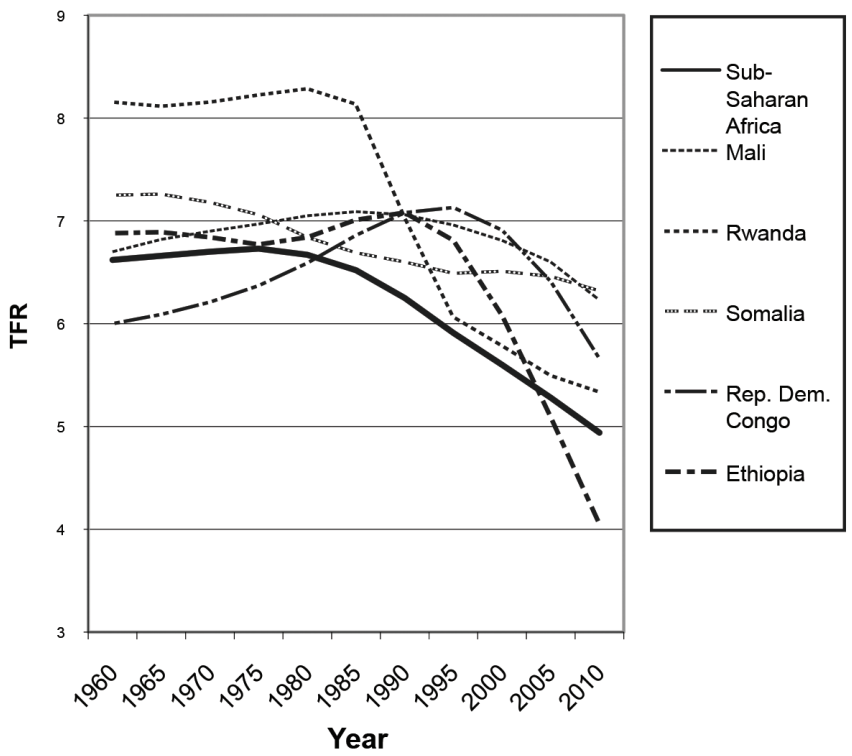

Source: World Bank data, in Google's public data

Furthermore, rapid population growth may exacerbate income inequality and strengthen authoritarian governments. Indeed, as Nancy Birdsall says $\mathrm{s}^{33}$, massive availability of labour often causes a reduction in salaries, which in turn increases wealth inequality. This increase in inequality prevents economic development policies from being as effective as expected. Indeed, a society where the majority of people are poor and poorly educated rarely creates wealth. Meanwhile the creation of an elite in contradiction with a vast poor majority, so poor that their subsistence is not guaranteed, leads governments to use strong measures

${ }^{33}$ Birdsall, Nancy. 1994. "Government, Population, and Poverty: Win-Win Tale." In Population and Development: Old Debates, New Conclusions", Transaction Publishers, New Brunswick (USA) and Oxford (UK), 1994, Ch.9. 
and restrict freedom and basic rights to curb revolts by the majority. This type of situation also stimulates corruption.

Young adults, particularly men, have a tendency to resort to violence if they are denied prospects such as education and jobs. Some studies show that countries with a disproportionately high percentage of adolescents are susceptible to political unrest and armed conflict. ${ }^{34}$

\section{Rapid population growth and the window of opportunity}

As mentioned earlier, the main issue in the linkage between poverty, rapid population growth and high fertility is the proportion of people who work in relation to the people who do not. This relationship is intuitive: the bigger the percentage of people who work the better off society is, considering all the other variables constant. In sub-Saharan Africa, around 50 per cent of the population is under 18 years old..$^{35}$

When a population has very high levels of mortality and fertility, its age pyramid is typically a triangle with a large base, many children and very few old people. When mortality decreases thanks to improvements in health care and nutrition, there will be changes in the age pyramid. Because these improvements will be sharper at very young ages, the proportion of children will also rise considerably for a few years. Later, the increase in young people's numbers and share of the total population will be greater. Eventually, the effects of health care will make the proportion of older people larger. If fertility declines sharply during the period in which there are not yet many old people, the proportion of people of working age will be the highest possible. This demographic dividend occurs over a relatively short time, but if a special effort towards education, employment and investments is made during this period, then the country can make a big leap forward.

It is important to note that, with rapid population growth and constant fertility and mortality levels, the number of extra people each year is bigger than it was the year before. With so badly needed improvements in health, mortality levels will decrease and the population growth rate will be higher, for the same fertility levels. Africa does not have much time to use this window of opportunity. With improvements in health services, particularly for children, mortality rates tend to de-

\footnotetext{
${ }^{34}$ Haub, Carl/ Sharma, O.P. 2006. "India's Population Reality: Reconciling Change and Tradition." Population Bulletin

${ }^{35}$ United Nations Population Fund (UNFPA). 2012. The State of The World Population 2012:by Choice, not by Chance. UNFPA, New York, pp 114
} 
crease and life expectancy to increase. If so, the proportion of older people will increase drastically, and even with an appropriate family planning system, the proportion of working age population in the total population will not increase substantially, a condition for a jump to a developed country.

The Berlin Institute for Population and Development ${ }^{36}$ reports, "In our study of 103 current and former development countries, we could show that no single country has developed socio-economically without a parallel decline in the birth rate." Sippel, Kiziak, Woellert and Klingholz used a cluster approach to scientifically prove that there is indeed a link between decreasing fertility and increasing development. They used cluster analysis, and their development indicators included economy, education, health, reproductive health, gender equality, and political and economic indicators. More specifically, they included gross domestic product (GDP) growth rate, gross national income (GNI) per capita, the Gini coefficient, the percentage of people without education, of people who attended primary and secondary school and of people who completed a university degree, life expectancy, infant mortality rate, maternal mortality ratio, gender development index, and the corruption perception index, among others.

They demonstrated that there was a correlation between a decline in fertility and a country's present level of development. The conclusion as to what came first - a decrease in fertility or socioeconomic progress - cannot be drawn from the cluster analysis, but looking at the history of the successful Asian Tigers, there is a clear relationship between them. Indeed, as May ${ }^{37}$ points out, “... the 'Asian Miracle' is attributable to a large extent (40\%) to rapid declines in fertility and age structures". Somehow the two variables seem to be the two sides of the same coin. Socio-economic progress is needed for a complete fertility transition and a decrease in fertility is necessary to guarantee rapid socio-economic progress. Furthermore, there are a number of potential development impediments that have been already presented.

In the 103 countries studied by the Berlin Institute, there was no country with a strong socioeconomic performance without a parallel decline in fertility levels. In addition, the most prevalent and severe problems today occurred in sub-Saharan Africa, where the 27 countries

${ }_{36}$ Sippel, Lilli; Kiziak, Tanja; Woellert, Franziska and Klingholz, Reiner. 2011. Africa's Demographic Challenges: How a Young Population Can Make Development Possible. Berlin: Berlin Institute for Population and Developmement, pp.6-10 .

37 May, John. April 2008. http://web.worldbank.org/WBSITE/EXTERNAL/ COUNTRIES/AFRICAEXT/0,,contentMDK:217 
with the greatest development problems were the ones with the highest fertility rates.

Nonetheless, even if fertility levels decrease to replacement level, the population will continue to grow for decades, due to the fact that high fertility in the recent past means that there are more mothers, and there will still be more mothers than in the recent past. However, a decrease in current fertility levels will slow the pace of population growth. It has been estimated that today's population in Africa is 7 per cent lower than it would be if no family planning programmes had been put in place. ${ }^{38}$

Most countries in sub-Saharan Africa have the age pyramids described above, as many Asian countries had a few decades ago. The decrease in fertility in these Asian countries was fast and for a long time the working age group grew while the child group decreased and the older, retired group was not yet very large. This made the proportion of working age people to non-working people quite high and this strong working force drove forward economic development.

\section{Road map}

Africa's people are its best asset. But if this asset is not managed carefully, the excess population can become a burden. As mentioned above, even after taking measures to decrease fertility to replacement level in a short time, the population would continue to grow for at least a generation. It is thus urgent to tackle all issues related to rapid population growth all together.

Firstly, the launch of a strong family planning network is perhaps the most important strategy. Linking family planning with basic health services and spreading it all over the country will have multiplying effects on its development. Indeed it will achieve several objectives, such as health improvement, better population structure and women's empowerment. It is true that economic and social development is the best contraceptive, but contraceptives are also essential to development. ${ }^{39}$

${ }^{38}$ Das Gupta, Monica; Bongaarts, John and Cleland, John. 2011. Population, Poverty and Sustainable Development: a Review of the Evidence. The World Bank, Development Research Group, June 2011, pp.13-15.

39 Sippel, Lilli; Kiziak, Tanja; Woellert, Franziska and Klingholz, Reiner. 2011. Africa’s Demographic Challenges: How a Young Population Can Make Development Possible. Berlin: Berlin Institute for Population and Development, pp.6-10 . 
Population growth and high birth rates can in no way be fully attributed to the desire to have large families. They are largely due to the fact that women and couples lack effective birth control methods. Often it is simply a question of ignorance, ignorance of the existence of contraceptive methods, misconceptions of potential side effects, ignorance of health benefits in having babies very early, spacing births and stopping childbearing before being too old. Women are so afraid of ending up without any living children, that they do not realize that mortality rates are much lower nowadays than they were in the past. ${ }^{40}$ Infant and child mortality rates are still very high but much lower than in the past.

There are some conditions to be tackled in order to decrease fertility and thus obtain the right size families:

- Strong women: gender equality ensures a low number of children

- Compulsory education for teenagers, as women's secondary education lowers birth rates

- Healthy children: when fewer children die, fewer children need to be born

- Access to family planning: decreasing birth rates through fewer unwanted pregnancies

- Mass media conveying advantages of right size families

Secondly, it is urgent to prioritize youth employment. A large group of unemployed young people is a burden to the economy as they do not produce but still consume, albeit little. But more than a burden they constitute a high risk to countries' peace and security. Governments, the international aid community and the national and international private sector need to launch programmes and investments that are labour intensive.

Thirdly, children and young people, the future of all nations, need to be properly educated. There is a need to survey workforce needs to help design an education system that will respond to present and future needs.

Fourthly, it is urgent to develop a green revolution and bring development to rural areas. This will greatly improve rural people's lives and prevent mass migrations to the cities.

40 Carvalho, A. 2005. "Mortality Perceptions and their Influence in Fertility Desires." PhD diss. University of Southampton, UK. (Carvalho, 2005), pp.226-237. 
The situation analysis presented here constitutes general aspects, and most indicators are averages of all countries in sub-Saharan Africa. Nevertheless, these countries sometimes diverge greatly from each other. There are common features to most of them, but there is a need to understand what the reality in each country is, what the real problems are and what particular issues they entail. There is therefore a great need for research on all the issues covered here, which means that there is a need to finance research institutions in the countries and provide technical capacities when needed.

There is also the need for greater advocacy with African leaders. Although there are some changes from previous positions regarding demographics and development, it is clear that family planning is not a priority in most African countries' socio-economic development strategies. The above-mentioned contraceptive prevalence in sub-Saharan Africa hints at a lack of a strong support. However the human cost and suffering of rapid population growth calls for a more active position.

These are the various dimensions of the demographic issues. They are intertwined and only a partial solution certainly will not produce the desired effects. Investments in the economy are fundamental for any country's improvement, but the population also matters for its sustainable development. Indeed, population size and, more importantly, population structure, constitute inseparable parts of the process. The number of non-economically active persons in relation to total population is important. In addition, there is a strong need to educate children in good schools, with good teachers. Education has to produce skilled people, people who will transform the country from backward to a developed, $21^{\text {st. }}$ century nation.

\section{Conclusions}

Whatever technology is created, there is a physical limit on the number of people in the world, as there is in Africa. ${ }^{41}$ In addition, it is important to consider that there is a human carrying capacity for each level of technology, productivity, wealth distribution, work organization, education, social discipline and the political system. ${ }^{42}$ Human carrying capacity for today's levels may have already reached its limits. Indeed, the basic criterion, feeding people, has not yet been completely met. There

${ }^{41}$ May, John. April 2008. http://web.worldbank.org/WBSITE/EXTERNAL/COUNTRIES/AFRICAEXT/0,,contentMDK:217

${ }^{42}$ Cohen, Joel. 1995. How Many People Can the Earth Support? W. W. Norton \& Company Ltd. London pp.368-398. 
is a need to improve all dimensions, but improvement cannot happen in a short time. Every decade of delay in reaching replacement level fertility implies significant ongoing population growth. As mentioned, no country has a strong socioeconomic performance without a parallel decline in fertility levels. Fortunately the impact of population growth on development is now back on the development agenda ${ }^{43}$.

Above all, population policy-makers should listen to those the most directly involved in childbearing, African women.

\section{References}

Beegle, K.; De Weerdt J. and Dercon, S. 2009. The intergenerational impact of the African orphans crisis: a cohort study from an HIV/AIDS affected area. International Journal of Epidemiology. 2009 Apr; 38(2):561-8.

Bongaarts, John. 2008. "Fertility Transitions in Developing Countries: Progress or Stagnation?" Population Council, New York, Poverty, Gender and Youth working papers, Working Paper No. 7, 2008.

Canning, D. and Schultz, T.P.. 2012. "The Economic Consequences of Reproductive Health and Family Planning." Lancet, 2012 Jul 14-20; 380(9837): 165-171.

Chamie, Joseph. 2007. "Population Trends: Humanity in Transition. International Peace Academy", New York, Coping With Crisis working paper series, June 2007. Cohen, Barney. 2006. Urbanization in Development Countries: Current Trends, Future Projections, and Key challenges for Sustainability. Technology in Society, 28 (2006) 63-80.

Ehrlich, Paul R.. 2008. "Demography and Policy: A view from Outside the Discipline." Population and Development Review, Vol 34, no. 1, March 2008, pp 103 - 113.

Emina, J; Begui, D.; Zulu, E.M.; Ezeh, A.C.; Elungata P.; Otsola, J.K. and Ye, Y. 2011. "Monitoring of Health and Demographic Outcomes in Poor Settlements: Evidence from the Nairobi Urban Health and Demographic Surveillance System." Journal of Urban Health, 2011. Jun; 88 Suppl. 2:S200-18.

Green, Elliott D. 2010. "The Political Demography of Conflict in Modern Africa", London: London School of Economics, Development Studies Institute (DESTIN) Working paper No. 10-11

Gribble, James and Voss, Maj-Lis. 2009. "Family Planning and Economic Well-Being: New Evidence from Bangladesh.” Population Reference Bureau, Policy Brief, May 2009.

Institute du Sahel, Centre d'Études et de Recherche sur la Population pour le Development (CERPOD). 1990. Population and Developpment dans le Sahel: les defis de la croissance rapide de la Population. CERPOD, Bamako, Mali, (1990).

King, M. 1996. "The Population Wolf and Demographic Entrapment in Rwanda." American Journal of Public Health, 1996 Jul; 86(7): 1030-1.

Nauriyal, DK. and Dutta, S. 2006. "Quantity-Quality Trade-offs, Familial Resources, Couple's Human Capital Attributes and Reproductive Decision Making." Demography India, 2006 Jan-Jun 35(1): 51-74.

${ }^{43}$ United Nations Population Fund (UNFPA). 2012. Population Matters for Sustainable Development. UNFPA, New York 2012, pp.3-4. 
Ocholla-Ayayo, A. C. 2000. "The African Family in Development Crisis in the Second Millenium." The African Anthropologist (Jounal of the Council for the Development of Social Science Research in Africa - COSDERIA), Vol. 7, No. 1. March 2000.

Orbeta, Aniceto Jr. 2005. Poverty, Vulnerability and Family Size: Evidence from the Philipines. Asian Development Bank Institute, Discussion Paper No. 29, June 2005.

Percival V., Homer-Dixon, T.. 1995. "Environment Scarcity and Violent Conflict: the Case of Rwanda." American Association for the Advancement of Science, Project on Environment, Population and Security, 1995 Jun(6), 18p.

Ravallion, Martin; Chen, Shaohua and Sangraula, Prem. 2007. "New evidence on the Urbanization of Global Poverty." Population and Development Review, Vol 33, no. 4, December 2007, pp 667-701.

Stephenson, J.; Newman, K. And Mayew, S. 2010. "Population Dynamics and Climate Change: What are the Links?” Journal of Public Health. 2010 Jun; 32(2):150-6.

United Nations Department of Economic and Social Affairs, (UNDESA). 2007. World Youth Report: Young People's Transition to Adulthood, Progress and Challenges. UNDESA, 2007. New York.

United Nations Population Fund (UNFPA). 2008. Special Youth Programme report. UNFPA, New York 2008.

United Nations Population Fund (UNFPA). 2012. Population Matters for Sustainable Development. UNFPA, New York 2012.

Vimard, P. 2008. "Africa and its Demographic Challenges: An Uncertain Future." Agence Française de Development, Department de la Recherche, Paris, 2008. Working Paper No. 62.

Von Braun, J.. 2007. "The World Food Situation: New Driving forces and Required Actions." Institute Food Policy Research Institute (IFPRI), Biannual Overview of the Food Situation presented in Beijing, December 2007.

World Food Program (WFP) and Food and Agriculture Organization (FAO). 2009. The State of Foof Insecurityin the World: Economic Crisis - impacts and Lessons learned. WFP and FAO, Rome 2009.

Zuehike, E. 2009. "Youth Unemployment and Employment in Africa Brings Uncertainty and Opportunity." Population Reference Bureau, Washington, 2009 February 


\title{
DOCTORAL STUDIES IN SUB-SAHARAN AFRICA AND THE PLANNED RESSESA INTERVENTION
}

\author{
Paulos Chanie and Paschal B. Mihyo
}

\section{Background and Introduction}

The extant literature on higher education in Africa attests the existence of African based higher education institutions before the advent of colonialism (Assie-Lumumba 2006). According to Lulat (2005) three African countries - Egypt, Ethiopia and Morocco - had higher education systems that were earlier contributors to knowledge creation and dissemination in the areas of religion and philosophy, and to the production of highly qualified religious leaders and thinkers. Nonetheless, modern higher education in Africa was introduced during the colonial period and had no link to the indigenous systems (Tefera and Altbach 2003). Modeled very closely on their European origins, African colonial universities were established in both Anglophone and Francophone Africa with an overall purpose of providing the necessary indigenous support staff for the colonial administration (ibid.). The number of these colonial universities was very small. Sall $(2004,181)$ indicates that 'At the time of independence, or roughly the late 1950s and early 1960s, the total number of universities and university colleges in sub-Saharan Africa, outside of South Africa, was fewer than 10 .'

During the first decade in post-independence Africa there was a great deal of enthusiasm for promoting higher education systems in the region. Almost all newly independent states started to establish their own universities. There were two major impetuses for opening the universities in many SSA countries. The first is symbolic based on the firm belief on the part of the founder leaders in universities as symbols of independent state hood or fruits of nationalism. The second is instrumental based on the belief that universities could be centres of human capital formation as well as hubs for the production and 
distribution of knowledge to eliminate poverty, ignorance and disease (Lulat 2005; AAU 2004; Sawyerr 2004; Gakusi 2010).

Although the newly created universities in sub-Saharan Africa were different from the colonial universities in their essential mission of nation-building and national development, they were modeled after some universities in Europe and North America and depended on ideas and practices of these universities. There were, however, attempts to make some changes on the then existing higher education system. As elaborated by Ajayi et al. (1996) and Akin Aina (1994) cited in AAU (2004), some of the changes include: widening access to increase students enrolment; establishment of new universities or new campuses of national universities in countries with large geographical spread; creation of specialized universities in fields such as technology and agriculture; changes in curriculum and other innovations such as the introduction of vocational and professional educational programs; greater subject choice (rather than specialization), and an emphasis on African culture not only through the study of the humanities but also through incorporating important aspects of indigenous knowledge into courses in medicine, technology and architecture; as well as government control of the administrative side especially in the hiring and firing of senior managers, such as Presidents, Rectors, Vice Chancellors, Directors and Deans.

The enthusiasm of the 1970s to expand and increase university education in Africa did not last more than one decade and half. From the 1980s up to the beginning of the new millennium universities and other Higher Education Institutions (HEIs) in sub-Saharan Africa were in state of crises characterized by poor quality of teaching, learning and research; absence of investment in libraries and infrastructure and deterioration of physical facilities; diminishing financial resources, declining salaries, and absence of research funding; brain-drain and mass departure of staff from higher education sector; and repeated closures of many universities due to political unrests (AAU 2004; Assié-Lumumba 2006) .

The literature on African higher education indicates that there are many causes for the deterioration of African higher education systems from the mid-1980s up to the end of 1990s (Adesina 2003; AAU 2004; World Bank 1986; Robertson 2008). The first fundamental challenge that severely diminished African countries' capacity to enhance the quality and accessibility of their higher education systems and expand 
the tertiary education sector in the 1980s was the then existing crises, which was reflected in political instability, wars and conflicts; poor economic growth and the debt crisis; and drought, famine and severe ecological degradation. The second was the structural adjustment programs that forced many African countries to reduce public expenditure by cutting spending on their national universities and focusing on primary and secondary education. Donors and lending organizations, especially IMF and World Bank's, main argument was that the economic and social returns on primary and secondary education were substantially higher than the returns on tertiary education. This economic analysis contributed to the view that public investment in universities and colleges brings meager returns compared to investment in primary and secondary schools, and that higher education encourages income inequality. The third challenge, which is the related or the consequence of the first argument, was the reduction on institutional support and training funds for higher education by international agencies; multilateral and bilateral donors, and other development partners. Most development partners regarded universities as white elephants (institutional elite enclaves) and reduced financial support to higher learning institutions. This has resulted in universities' lack of funding for research activities and infrastructure, lack of access to information technology and current literature; and absence of capable academic members of staff. It also made most of the higher education institutions unattractive to prospective doctoral students and most of the students choose to study abroad. The last challenge was the African universities themselves, which contributed to the deteriorating quantity and quality of $\mathrm{PhD}$ graduates they now suffer from. Most of the universities in attempting to respond to the demand for a rapid increase in student numbers, succumbed to the temptation to admit students of low caliber, recruit staff incapable of coping with the increasing teaching load, and resort to improvisation rather than construction of new physical facilities. Poor management of universities, weakness in expanding funding sources, and heavy government interference in the internal management and suppressing academic freedom of faculty were also internal factors contributing to the failure of post graduate studies in Africa.

During the crises of the mid-1980s and the 1990s efforts to promote doctoral education in many sub-Saharan African countries was very low. AAU's 1999 Guide to Higher Education in Africa showed that 
towards the end of the 1990s, forty countries in Sub-Saharan Africa had among them 174 institutions officially designated as "universities" but of these, only two countries - Nigeria and South Africa - run PhD programs (Sall 2004). This crises period in general had constrained many African countries from having their own $\mathrm{PhD}$ graduates that are capable of producing and disseminating knowledge by generating their own theories, models and analytical tools that can be applied in the context of African countries.

In short, this neglect of higher education since the 1980s has resulted in the externalization and depletion of African intellectual capacity and killing capacity of universities to generate the caliber of an intellectual with the capacity, competence and much needed professional skills required to manage and solve Africa's problems. This intellectual incapacity is felt across Africa as a key feature of the development crisis that has persisted from the colonial times to the present.

At the dawn of the new millennium and after nearly a decade and half of neglect, a renewed interest in expanding higher education in Africa has emerged. African governments, international financial institutions and donor agencies have shown new interest in higher education in Africa. There are various interrelated factors that have encouraged such reconsideration (see Adesina 2003; AA, 2004; World Bank 2002; Robertson 2008; Altbach 2006). Two important factors can be cited.

The first factor is the credence given to the importance of a knowledge economy to national and global economic growth and increased prosperity. International financial institutions, donors and African governments have now accepted that the outcomes of a knowledge economy - innovation and technical changes - are more crucial key factors for economic growth than natural resources. More importantly the World Bank's acknowledgement of tertiary education as a critical pillar of worldwide human development as well as the construction of knowledge economies and democratic societies resulted in the influencing of many governments in Africa to open Masters and Doctoral study programs. Tertiary education, both at Masters and Doctoral level is recognized to provide high-quality scholars and professionals that are able to bring innovative changes for the development of a country, help policy actors to make important decisions which affect societies; and produce a critical mass of scientific and technological innovators (ibid.). 
The second factor is the urge by African governments to enhance the provision of quality higher education which has been compromised by the shrinking availability of public resources. Governments have also realized the urgent need to produce highly educated personnel that are capable of critically analyzing local and national problems, providing alternative policies and opportunities; and carrying out critical basic research, theory building and experimentation; and increasing access to higher education to all members of the society including underrepresented sections of Africa's populations such as women, minorities, the poor and rural people (ibid.).

Due to the above major reasons, it was at the end of the 1990s that Masters and $\mathrm{PhD}$ programs were recognized as pivotal to development and expanded in many universities of Africa. This wide recognition of relevance and importance of post-graduate studies in Africa has been forcing universities to continuously refine their mission and vision and increase their capacity for competition and cooperation for students, staff resources and funds. Universities have been viewing their path to success as dependent on several quantitative and qualitative indicators or factors. On the quantitative side they have been required to have increased student enrolment in terms of increased head count and quality; increased financial resources; stable and increased staff resources; adequate and functional IT facilities; supportive and up to date equipment and buildings; state of the art laboratories and libraries and adequate facilities for student and staff accommodation. On the qualitative side they are required to sharpen the career orientation of their courses to make them more attractive to potential students and their potential employers; to keep on improving on their image in order to retain the confidence of key stakeholders and gain more and sustained political, financial and institutional support; to institutionalize research and teaching activities in order to attract funding based on long term cooperation with stakeholders; to attain favorable gender balance among staff and students for purposes of legitimacy and meaningful contribution to national and regional development; and to develop clear indicators of quality and relevance of their programs if they have to remain players in the competitive knowledge driven global and regional economies (Bunting and Cloette 2012; Kotecha 2012).

After a decade of attempts to expand tertiary in many African countries, there are two views on the current status of the sub-Saharan Africa post graduate studies, especially on the $\mathrm{PhD}$ programs. The 
first states that many African universities are simply struggling to survive with their programs and anything else that is happening is coincidental and incidental to survival. The second view argues that many universities are making encouraging progress in producing a good number of $\mathrm{PhD}$ graduates, irrespective of various challenges they are confronted with. Following the latter view, this paper will first discuss the success and challenges of post- graduate studies in sub-Saharan Africa. It will then outline an initiative by the Organization for Social Science Research in Eastern and Southern Africa (OSSREA), which is a project known as Research School for Social Science in Eastern and Southern Africa (RESSESA) that has the objective of supporting African universities to fast track their PhD programs. The basic assumption behind the project is that by pooling human and other resources, these universities will maximize on the economies of size, scope and scale, churn out bigger numbers of highly qualified $\mathrm{PhD}$ graduates in a shorter time and at a lesser cost than is currently the case.

The main source of information for discussing the current status of $\mathrm{PhD}$ education in sub-Saharan Africa is gathered from the reports presented by ten universities at an experience sharing workshop organized by OSSREA to discuss the existing challenges and opportunities of $\mathrm{PhD}$ programs in sub-Saharan Africa. The workshop was organized in Nairobi, Kenya from 22-26 August 2011. Participants were from ten universities in the region, namely, Egerton University (Kenya); Addis Ababa University (Ethiopia); University of Namibia (Nambia);Moi University (Kenya);National University of Rwanda; University of Khartoum (Sudan);University of Dar es Salaam (Tanzania); Makerere University (Uganda); University of Zimbabwe; and The Catholic University of Eastern Africa (Kenya). The reports presented are used as primary sources of information and the universities are considered as case studies for this paper. Secondary sources and the authors' long term experience in the higher education sector are also used in writing this paper.

The discussion on the status of $\mathrm{PhD}$ education is presented in five main topics, namely recognition and expansion; objectives, procedures and structure; research methodology training; supervision; and facilities in PhD programs. The section on RESSESA will outline the envisaged objectives and activities under the project. 
Many African governments are giving due recognition and political support to the expansion of the higher education system, especially $\mathrm{PhD}$ programs. They have developed and enacted strategic and policy documents that aim at increasing the relevance of higher education to the labor markets of each country; increasing access to higher education at gender and regional/provincial levels; enhancing the capacity of Higher Education Institutions for the creation of new knowledge; increasing efficiency by balancing ratios of students and staff and developing incentives systems; and improving quality by improving the capability of staff to use their skills. They have also established Ministries, Commissions, Councils for Higher Education that are separate from bodies responsible from other levels of education. Members of these Commissions or Councils are also eminent Professors who have earned recognition in their academic and research careers. In some countries there is also a transition from Head of State being Chancellors for public universities to eminent personalities especially academics indicating political leaders willingness to delegate technocrats to lead the higher education systems. Governments are also allocating budgets from the national coffers for higher learning institutions, especially $\mathrm{PhD}$ programs, to cover the operating costs and avail infrastructure including buildings, computer labs with internet, video conference facilities, postgraduate libraries, staff development program, etc.

The wider recognition given for higher education in Africa is also witnessed by the various regional and continental initiatives underway to expand higher education system and research in Africa. The African Union Commission (AUC) has embarked on program aimed at establishing the Pan-African University (PAU) and the African Social Sciences Research Council (ARC). The African Development Bank (ADB) has put in place a long term Higher Education, Science and Technology Programme (HEST) and reorganized the African Development Institute (EADI) in order to support its regional members to address core issues in the advancement of agriculture, infrastructure, governance, higher education, science and technology. At regional level regional economic communities such as the East African Community (EAC), the Common Market for Eastern and Southern Africa (COMESA) and the Southern African Development 
Community (SADC), have also launched and are implementing human resources policies predicated upon the creation of critical skills that can increase opportunities for their member countries to increase their competitiveness, unleash the production potential of their citizens and enable the public and private sectors in these countries to be strong and formidable players in the global economy. These economic communities have passed protocols on education and training that are aimed at developing regional science and technology policies; enhancing technical and technological capacity and capabilities for innovation, absorption, diffusion, and innovation of technology; facilitating joint research facilities and programs; establishing centers of excellence; and developing capacity for assessing, monitoring and developing data on policy performance and the free movement of researchers in the region. Few of these initiatives include the SADC Protocol on Higher Education; the Inter University Council for East Africa; Southern African Vice Chancellors Council, etc.

The proliferation of post-graduate studies, especially $\mathrm{PhD}$ programs, witnesses the wider recognition for graduate studies in Africa. It has created much greater opportunities for students to do higher degrees and earn a relatively better living in their own countries and for the countries to count on their own human resources. For instance, Ethiopia currently has 215 post-graduate programs of which 67 are $\mathrm{PhD}$ programs covering most fields in the social, natural and technological sciences. At present the total enrollment in all post-graduate programs is close to 3,000, of which there are about 1,300 students currently enrolled in the $\mathrm{PhD}$ programs. Ethiopia since 2010 has also planned to train at least 5,000 PhDs in less than ten years. At National University of Rwanda (NUR) growth in Masters programs has gone from around ten to about 30, with more on the way. NUR has also established an in-country $\mathrm{PhD}$ program (with support from external academics); in 2010 there were $23 \mathrm{PhD}$ students registered, aiming for over 100 in 2013 and perhaps 1,500 by 2023. In 2011 in Sudan, the University of Khartoum had 24 faculties, with 120 different departments; ten institutes of different disciplines; 32,000 students of whom 24,000 are undergraduate students; and 8,000 graduate students including $\mathrm{PhD}$ students. In Uganda the Mbrara University of Science and Technology, which is a young public university that started operation in 1989 and has only three faculties and two institutes (Medicine, Science and Development Studies, and the institutes of Computer Science and Tropical Forestry 
and Conservation, respectively) has started postgraduate programs in 2003. In its $\mathrm{PhD}$ program it has $18 \mathrm{PhD}$ students that have registered in Development Studies and Psychology (13 in Development Studies, five in Educational Psychology). Many universities in Africa have similar developments in their $\mathrm{PhD}$ programs.

Irrespective of the encouraging moves, especially the proliferation of $\mathrm{PhD}$ programs, the political will of governments and the institutionalization of $\mathrm{PhD}$ programs in many of the universities, there remains challenges. The following six challenges can be identified:

a) While colleges and universities are over flowing in the region with large class sizes, enrolment for graduate studies is still very low in sub-Saharan Africa universities. While overall enrolments went up in most universities between 2001 and 2010, post graduate student enrolments at Masters and $\mathrm{PhD}$ level is low by international standards. Table 1 provides the dire situation in sub-Saharan Africa. Table 1 compares tertiary education enrollment in the different regions of the world and indicates the precarious situation of sub-Saharan Africa.

Table 1

\begin{tabular}{|c|c|c|c|}
\hline $\begin{array}{c}\text { Gross Tertiary } \\
\text { Enrolment Ratios in \% }\end{array}$ & & & \\
\hline Region & 1999 & 2002 & 2005 \\
\hline Arab States & 19 & 20 & 22 \\
\hline Central \& East Europe & 39 & 50 & 57 \\
\hline Central Asia & 19 & 23 & 26 \\
\hline East Asia \& the Pacific & 14 & 19 & 24 \\
\hline Latin America \& the Caribbean & 21 & 26 & 30 \\
\hline $\begin{array}{c}\text { North America\& Western } \\
\text { Europe }\end{array}$ & 61 & 67 & 70 \\
\hline South \& West Asia & n.d. & 9 & 10 \\
\hline Sub-Saharan Africa & 4 & 5 & 5 \\
\hline
\end{tabular}

Source: UIS, 2007 cited in Mohamedbhai $(2008,6)$.

b) Other studies also show that most of the universities are predominantly teaching universities with big numbers of undergraduate stu- 
dents and small numbers of graduate students. In the year 2012 about $87 \%$ of the students at Makerere University, 91\% at University of Eduardo Mondlane, $78 \%$ at the University of Ghana, $70 \%$ at the University of Dar Es Salaam and 58\% at the University of Botswana were under-graduates. For the University of Botswana an additional 26\% were under-graduate diploma and certificate students. Masters students were a small number at all the five universities. At Eduardo Mondlane they were only $2 \%$, University of Botswana $5 \%$, Makerere $8 \%$ and University of Dar es Salaam and University of Ghana 10\% each (Buntimng and Cloette, 2012: 35). It is evident from the above figures that given the present pace the majority of the universities in sub-Saharan African region will never be able to meet the increasing demand for more $\mathrm{PhD}$ graduates needed by the ever increasing number of universities, think tanks, research organizations, policy management units, and regional and international organizations.

c) Although many universities are actively involved in the election of university officials (Vice Chancellors, Deans and Directors), political appointment and government interference in university administration is still pervasive. As gathered from the case study universities political appointments have resulted in having university officials of low caliber that do not support and facilitate postgraduate training programs. Such appointments have a negative impact on the budgetary facilitation of postgraduate program, research, quality of $\mathrm{PhD}$ studies and completion rates of post-graduate studies. For instance universities that are led by undeserving officials are not capable of fully utilizing budgets allocated by their governments and are incapable of diversifying funding sources for $\mathrm{PhD}$ programs. This has resulted in constraining $\mathrm{PhD}$ candidates from collecting sufficient and comprehensive information through field work, getting necessary academic resources, accessing data bases and computer facilities and timely completion of their studies. It has also increased the number of dropouts.

d) Government heavy interference in post-graduate admissions is also a critical concern. Universities are instructed by national governments to accept a large number of students as they are given quotas and list of students to enroll in their Masters and $\mathrm{PhD}$ programs and in some cases specify the fields of post graduate studies they have to run. This is done without due regard to the number of senior professors available for teaching research methodology courses and supervise $\mathrm{PhD}$ candidates as well as budget and infrastructure to supports the teaching and learning process. In all case study universities there is large staff - student ratio leading to lack of supervisors and inability to provide research methodology and foundation courses. Ethiopia is a case in point where there is heavy government involvement in PhD candidates' selection 
and admission and as a result there are cases where $20 \mathrm{PhD}$ candidates are assigned for one supervisor at Addis Ababa University.

e) Post-graduate Studies have also very little prominence as academic institutions are not still ready to recognize the findings of $\mathrm{PhD}$ research projects and use them as bases for further research and teaching purposes. This situation has made many $\mathrm{PhD}$ candidates question the relevance of their studies. As the credence given to $\mathrm{PhD}$ studies in sub-Saharan Africa is low and the financial and academic resources are meager, potential candidates also prefer to pursue their studies in the global North rather than in their home countries.

f) Lack of functional data, information and statistical systems is also a critical challenge. Governments are not giving due considerations on collecting reliable and complete information on their higher education system. As a result data in some of the universities are not centrally kept and may be unreliable or incomplete. In relation to this, Bunting and Cloette $(2012,7-8)$ pointed out the dearth of data on the status of post graduate studies in Africa by indicating the difficulty of getting complete information on number and other attributes of full time students as well as students completion rates, income and expenditure of the PhD or Masters programs and staff teaching loads.

\section{Objectives, procedures and structure of $\mathrm{PhD}$ programs}

The case study universities in the region have objectives and learning outcomes for their $\mathrm{PhD}$ programs as well as structures for the management of the post-graduate studies. For instance NUR's PhD program has five learning outcomes on subject knowledge and understanding, subject application, cognitive skills, communication and presentational skills, personal and transferable skills. Universities in Zimbabwe, Kenya, Ethiopia, and Uganda have also stated such goals in their PhD programs.

All universities included in this study have post-graduate Schools/ Directorates/Boards and quality assurance units that are responsible for managing the affairs of doctoral studies and research. For instance the University Namibia, Egerton University, Moi University, Addis Ababa University and the University of Sudan have Schools of Postgraduate Studies headed by Deputy Vice-Chancellors or Vice-Presidents in charge of research and post graduate studies. The roles of such bodies include, among other things, managing and quality assurance 
of admission, approval of research topics, supervision, funding of research and examinations. There are graduate committees, boards and other similar bodies responsible for managing the various activities of $\mathrm{PhD}$ programs. Egerton University, for instance, has an examination board which constitutes the Dean, the Director of Graduate School, supervisors, Senate representative, Faculty representative to Graduate School, external examiner and internal examiner. In the University of Namibia coordination of post-graduate $(\mathrm{PhD})$ research and supervision is done at two levels: School of Postgraduate Studies and Faculty level. In the same university there is also Multidisciplinary Research Centre (MRC) that coordinates collaborative research and supports for Post-graduate Research Fellows.

Universities have also rules and procedures on admission, proposal development, fieldwork, thesis defense and other related issues. The National University of Rwanda has criteria for acceptance to the $\mathrm{PhD}$ program which include, among others, minimum of honors degree or Master's degree in relevant subject and minimum of two qualified supervisors (PhD and publications). In the University of Khartoum, registration for $\mathrm{PhD}$ starts by writing the proposal with consultation with a supervisor, followed by proposal presentation in a seminar, approval by the Departmental Board, the Faculty Research Board, the Graduate College Board respectively. At the Moi University the process involves first the approval of the proposal at departmental graduate seminar level and final approval at the level of school of graduate seminar. The Catholic University of East Africa has also an Ethics Research Committee which receives, vets and approves research projects that conform to ethical standards. Moreover, universities have undertaken organizational reforms that led to decentralized decision making and reduced red tape; they have also introduced curriculum reforms that are aimed at attracting more students and support from employers. However, in spite of these essential procedures and processes being put in place, the selection processes are very lengthy and in some of them it takes over two years before a student is registered. Some of these universities require a fully-fledged proposal from aspiring students before they can be admitted, while it is sufficient to require applicants submit a concept paper on their intended field of study and develop it further to full proposal with the help of a supervisors.

In addition, in spite of the achievements by universities in terms of laying down systems to facilitate the production of $\mathrm{PhD}$ graduates, 
there are various challenges. These include over-centralization of the graduate program; inaccessibility of university management; long winding decision processes; and long and too frequent meetings. Such challenges have contributed to long delays in admission to $\mathrm{PhD}$ programs, approval of proposals, and examination of theses. They have also resulted in poor information flow among offices of graduate studies, academic departments, administrative offices, $\mathrm{PhD}$ candidates and supervisors; lack of transparency in decision making on admission and graduation, and absence of prior and clear communication among all those actors involved in running the $\mathrm{PhD}$ programs.

Other studies also indicate that there is also lack of long range planning and scenario building by the universities. On 13-14 October 2011 the University of Zambia and the Copperbelt University of Zambia hosted a SARUA leadership meeting on 'Building Higher Education Scenarios 2025: Agenda for Development in SADC'. It was noted at this meeting that while most universities in the SADC region have planning units, annual plans and even strategic plans, the majority of them focus on day to day challenges in the national, regional and international contexts and the planning process focuses on short term periods of a maximum of five years (Kotecha et al. 2012). Lack of long term planning and scenario building may be one of the factors behind unpredictability of funding, enrolments, staffing levels and demographic change within universities. This is compounded by lack of systematic ways of sharing information arising out of research within and among universities.

\section{Research methodology training for $\mathrm{PhD}$ candidates}

The two commonly employed modalities of running $\mathrm{PhD}$ programs in many universities around the world are taught $\mathrm{PhD}$ (where candidates are offered disciplinary courses, research methodology courses, sit for comprehensive exams and write dissertations) and research based $\mathrm{PhD}$ (where candidates directly engage in their research project without taking disciplinary courses and with or without taking research methodology courses). In the universities studied almost all $\mathrm{PhD}$ programs in social science and humanities are research based, perhaps due the European influence. There are, however, few programs that have started to offer taught $\mathrm{PhD}$ programs. The Addis Ababa Univer- 
sity has few taught $\mathrm{PhD}$ programs although most of the $\mathrm{PhD}$ programs in social science and humanities are research based. The University of Dar es Salaam - College of Social Science offers PhD by thesis in all departments but has introduced $\mathrm{PhD}$ by coursework and dissertation in Economics (in 2002/03) and Political Science (in 2010/11).

Although most of the case study universities run research based $\mathrm{PhD}$ programs, there are some universities that are not offering courses on research methodology for $\mathrm{PhD}$ students. In almost all of the universities in Sudan, at the University of Zimbabwe, and in some departments of University of Dar es Salaam students rely heavily on research methodology courses they get during their Higher Diploma or MA/MSc study, which are of basic and introductory nature. As a result, the students rely primarily on the directions and instructions of the supervisor to enhance their research capabilities.

With the exception of the above mentioned universities, all universities in Sub-Saharan Africa included as case studies run research based $\mathrm{PhD}$ programs to prepare their students for research and writing of their doctoral theses through offering courses on both qualitative and quantitative research methods. They offer trainings on the mechanics and mechanisms of writing research proposal, qualitative and quantitative data analysis, and interpretation and report writing. Candidates are also exposed to various statistical software programs, especially ATLAS and SPSS. PhD candidates in almost all universities are also exposed very early to research methods during their graduate and undergraduate studies (BA/BSC and MA/MDS/MS/MSc). Some of the universities also reported that the research methodology trainings are relevant and capable of equipping students with skills and knowledge to complete their $\mathrm{PhD}$ research projects.

Nonetheless, the following challenges are evident regarding trainings on research methodology courses for $\mathrm{PhD}$ candidates. These are the common challenges reported by participants from the ten universities included in the study (Egerton University (Kenya); Addis Ababa University (Ethiopia); University of Namibia (Namibia); Moi University (Kenya); National University of Rwanda; University of Khartoum (Sudan); University of Dar es Salaam (Tanzania); Makerere University (Uganda); University of Zimbabwe; and The Catholic University of Eastern Africa (Kenya).

a) The depth and the breadth of the content on research methodology are very limited and weak in equipping $\mathrm{PhD}$ candidates with compre- 
hensive and adequate knowledge and skills to clearly develop their research proposals, collecting information using surveys, questionnaires, interviews, and focus group discussions, conduct analysis and write the thesis. PhD candidates also lack skills on how to select a representative sample and have little knowledge on sampling errors and non-sampling errors that creep into the results of the research. Candidates confuse between data description and data analysis and believe that putting some figures in a table, making some charts, and then making some comments, is analyzing the data. They also lack the skills to present their dissertation in an organized text, to list the references, and to present tables and charts in the text or annexes. Trainings offered on statistical software -ATLAS and SPSS - are limited. Little time is also devoted to courses on improving skills in scholarly writing and most programs do not organize writing workshops. The research methodology trainings are also not supported by department and faculty seminars and other interactive forums for exchanging ideas. The above and other challenges, among other things, have made students thesis to be inconsistent and lacking clear theoretical and conceptual focus, a text un-enjoyable to read, and full of repetitions regarding preconceived opinions, lacking facts and evidence for strong claims and having little contribution to new knowledge and policy making.

b) The modes of delivery of the course are also problematic as the courses are more theoretical and abstract. There is disconnect between the curriculum and its practical application and little efforts are made to assist the PhD candidates internalize the discipline of research and make learning experiential. Though variations exist among programs, the main modes of delivery of research methods courses include: lectures and presentation of individual and/or group papers and written examinations. The lecture method is preferred in teaching research methodology courses and has in most cases led to rote learning and regurgitation of facts in examinations. Although it is doubtful whether written examinations can provide a proper insight into the students' ability to grasp the fundamentals of research, many universities provide exams at the end of the course. Platforms for e-learning, distance and virtual learning across departments, colleges and partner universities are by and large absent. The use of video-conferencing and tele-conferencing across departments, colleges and partner universities is weak or non-existent.

c) The timing for offering research methodology courses is not appropriately scheduled as they are given when there are willing professors that can offer the research methodology courses at their convenience.

d) There is absence of standardized research methodology courses across departments, college, faculties, and institutions of the same uni- 
versity let alone at national and regional level. There is also poor networking among universities at national level and the region at large. Sharing of experts in the region for capacity enhancement and developing contextualized material, manuals, textbooks for teaching $\mathrm{PhD}$ research methodology is absent. The quality assurance mechanisms at national and regional levels are weak.

e) Courses offered for $\mathrm{PhD}$ candidates are not different from those offered to Masters and Bachelor level. There exists a similar approach to the curriculum content and mode of delivery of research methodology courses at all levels. $\mathrm{PhD}$ training in many universities is not producing new knowledge because those involved in teaching methods courses teach set packages, as tools to be taken from the shelf. Those who are teaching the courses are usually familiar with a restricted range of methods and one doubts whether $\mathrm{PhD}$ candidates are exposed appropriately on how to conceptualize and analyze the social world from different perspectives using emerging research methodology tools.

f) There is lack of trained personnel to handle research methodology courses. There is also bias in the manner research methodology is handled. Some teachers are more comfortable with qualitative methods while others prefer quantitative methods. Specialists in the quantitative field are also very few. All the case study universities provide both qualitative and quantitative research methods. But there is little integration of the two. None of the universities is familiar with multi or mixed or integrated methods of research and tools for multi-level analysis. The courses are taught by different professors and are taken as independent and unrelated disciplines.

g) Team teaching as a mode of delivery, which could help provide postgraduate students with broader insights into various aspects of research methodology, is not practiced. Except at the University of Makarere, all the universities have no specific or tailor made programs for developing the capacity of the staff involved in $\mathrm{PhD}$ training.

\section{Supervision of PhD candidates:}

$\mathrm{PhD}$ supervisors or $\mathrm{PhD}$ promoters or $\mathrm{PhD}$ advisors play important roles for $\mathrm{PhD}$ training. All case study universities make all efforts to assign supervisors, who are conversant with $\mathrm{PhD}$ candidates' areas of research and specialization. In most of the cases dissertation supervision begins after candidates identify a research topic or problem and submitting it to a department graduate committee or other bodies re- 
sponsible for the same. The experiences in assigning supervisors differ among universities and departments within same universities. In some students may either nominate a supervisor or will be assigned one from among the staff who has interest in the student's topic. In others a student may also be assigned to a committee of advisors where one of them takes main responsibility and serves as chair -this happens when a student takes up a highly interdisciplinary research topic. In few cases a student may join a research project of a professor, who is her/his promoter.

As reported by the participants from the case study universities, it is indicated that there are dedicated and committed supervisors that put all their time, energy and accumulated knowledge in supporting their students. They guide candidates through all stages of the research process to make sure that candidates complete their research projects and produce new knowledge. There are however challenges regarding supervision of $\mathrm{PhD}$ students. The following were the common problems identified by the participants from the ten Universities included in this study.

a) Shortage of senior academics well-versed and well-experienced in the teaching of $\mathrm{PhD}$ courses and supervision of dissertations, who have track records of research and publications is a critical problem in all $\mathrm{PhD}$ programs. In some of the universities there are only few Professors that are knowledgeable and have adequate experiences in guiding $\mathrm{PhD}$ candidates. For instance Mbrara University of Science and Technology offers a $\mathrm{PhD}$ program in Psychology but there is no academic staff that holds a $\mathrm{PhD}$ degree in the department. In almost all the universities in Sudan, except two or three old ones, there is a shortage of senior staff to supervise $\mathrm{PhD}$ degrees. In other universities there are aging Professors who are not internet savvy and students complained that the Professors demand that they hand in their thesis chapters in hard copies not online. Newly graduated $\mathrm{PhD}$ students are also assigned as supervisors of $\mathrm{PhD}$ candidates, although they have less capacity to successfully lead a $\mathrm{PhD}$ candidate through all the stages in the $\mathrm{PhD}$ project. Students also depend on foreign supervisors leading to remote and virtual supervision. For instance many universities, especially NUR, rely on expatriate staff and external academics to supervise. Getting a supervisor from other universities abroad or in the continent is a hurdle in many $\mathrm{PhD}$ programs. Although there is no complete data on the staff-student ratio on $\mathrm{PhD}$ programs, it is 
possible to see the mismatch between enrolment of postgraduate students and availability of staff from related studies on the postgraduate studies. Buntimng and Cloette (2012) showed that at Makerere the number of academic staff grew at an annual rate of $1.4 \%$ while post graduate students enrolment grew at annual rate of $2.4 \%$. At the University of Dar es Salaam, undergraduate enrolment doubled between the academic year 2000/01 and 2007/08 while postgraduate enrolment quadrupled. But while the number of students went up at an average rate of $14.1 \%$, the number of full time staff increased at an average of 9.3\%. The student staff ratio increased from 13:1 to 16.1 in the natural sciences and from 8:1 to $14: 1$ in the humanities. A study of tertiary education in the SADC region (Mouton 2011) showed that there are a total of 8,441 academic and research staff holding $\mathrm{PhD}$ degrees in the region but $65 \%$ of them are in South Africa. Surprisingly, Zambia has only twelve doctoral staff, Namibia has $33 \mathrm{PhD}$ academics, and DRC has only 107 graduates teaching in the Science Engineering and Technology subjects.

In several universities the number of $\mathrm{PhD}$ holders has either stagnated or dropped, due to brain drain, demographic transition and other causes. In Zimbabwe, for example, it has fallen from $60 \%$ in 1999 to $7.9 \%$ in 2010. In the six public universities in Kenya, the number of $\mathrm{PhD}$ holders among academic staff ranges from $25 \%$ at MasindeMuliro University to $32 \%$ at Maseno University, an average of $39 \%$ at Jomo Kenyatta University of Agricultural Technology, Egerton and Moi Universities, to $46 \%$ at Nairobi University. Out of the twelve private universities in Kenya only the United States International University has $43 \%$ of its staff with Ph.D. degrees. At Kiriri University none has such qualifications and the remaining ten have an average of $17 \%$ of staff with such qualifications. At Addis Ababa University the number of Associate Professors and full Professors, a critical input to the $\mathrm{PhD}$ training, constitutes only $15.28 \%$ of the total staff population. The situation is almost the same in many universities, although it is slightly higher in the public Universities in Sudan and lower in Namibia, and even much lower for Rwanda. The low number of $\mathrm{PhD}$ holders in these countries affects not only teaching at all levels but constrains the capacity of the universities to mount effective, quality postgraduate programs. It also affects the quantity and quality of research outputs as many of the $\mathrm{PhD}$ holders in these universities have little time or capacity to do research. 
One of the reasons for the un-met demand for more academic staff resources, especially $\mathrm{PhD}$ holders, is the rapid expansion of higher education institutions both in the private and public sector. The proliferation of Master's and $\mathrm{PhD}$ programs in many African countries has also resulted in excessive teaching and advising load on senior staff, who become less productive in doing research and producing and dissemination new knowledge in their field of specialization. Increasing enrolments have a negative impact on staff development. As staff is called upon to teach more students in bigger classes for longer periods, time for staff development becomes shorter and in the majority of cases inadequate. That partly explains why the number of staff with Doctorate degrees has been low and is aggravated by the rise of new universities that have taken the existing stock of doctoral graduates without investing in the development of their own.

The problem of lack of adequate number of Professors is also made worse because supervisors of Master's and Doctoral students are not adequately compensated for their time. In Ethiopia there is a low incentive scheme for staff teaching and/or supervising $\mathrm{PhD}$ students. As a result the level of commitment by supervisors is limited because there is no extra remuneration for supervision. For instance a Professor, who is supposed to supervise $\mathrm{PhD}$ candidates, earns a monthly salary of USD 400 and is not paid for supervising a $\mathrm{PhD}$ candidate unless his teaching load exceeds the set limit. The highest supervisory fee in Kenya is paid at Moi University where lecturers are paid KS 100,000 (USD 1,200) for PhD thesis supervised; at The Catholic University of EA the university pays 25,000 (USD 295) - to the first supervisor and 15,000 (USD 177) - for the second supervisor for a PhD thesis. Most of the senior academics in many universities prefer to carryout teaching at universities and doing private consultancy activities rather that engage in supervision of $\mathrm{PhD}$ candidates. Moreover the capacity of supervisors is not up to expectation as not all supervisors have been properly trained for supervision duties. There are no programs yet in place for training supervisors. Some of the reasons are the decrease in the funding of staff training; the brain drain of university lecturers due to political and economic reasons; and appointment of senior Professors in top government posts.

b)Many of the universities do not have comprehensive graduate student handbooks that explain the relationship between supervisors and their $\mathrm{PhD}$ candidates, especially their respective responsibilities 
in the whole research process and the timelines in terms of submission of proposals, presentation of proposals, fieldwork, submission of drafts thesis, provision of comments on the drafts, defense and other related issues. Lack of clearly stated guidelines concerning dissertation supervision, undermines the quality of $\mathrm{PhD}$ programs and makes the $\mathrm{PhD}$ process take an unnecessary long period of time.

c) The relationship between supervisors and supervisees is very weak. Reports from the universities that participated in this study indicate that some supervisors do not have students at their heart; clash with students on their topics, theoretical framework, methodology and writing styles; do not listen to students but want to direct them in areas where they are comfortable to supervise while students don't have knowledge in such topics; take long to read proposals, fieldwork reports, draft chapters and final thesis manuscripts; fail to understand the topics they supervise, provide contradictory comments to students sometimes, they have unrealistic expectations from students, and are poorly involved in the supervision of fieldwork. It has to be noted, however, there are challenges on the side of the $\mathrm{PhD}$ candidates. Some $\mathrm{PhD}$ students lack self-discipline in relation to work habits, willingness to respond to comments and criticisms, willingness to work independently, desire to enquire, and team spirit. Many students take too long to address corrections on their work; students also embarrass their supervisors by coming for defenses without making the necessary preparations.

d) The weak relationship between supervisors and supervisees has been one of the reasons for $\mathrm{PhD}$ candidates to take unnecessary longer period of time and failing to complete their studies on time or at all. There are cases where approval of proposals took up to four years. Examination of theses also takes too long, as long as between six months - two years to get supervisors and examiners submit reports on candidates' thesis. In many universities the dropout rate is also high as there are $\mathrm{PhD}$ candidates that could not complete their research projects and fail to graduate. Information on dropout rate is not easily accessible but Buntimng and Cloette $(2012,55)$ indicate large number of dropouts in post- graduate programs. The authors observed that 'Makerere has high drop-out rates in many of its programs and calculations indicate that $50 \%$ of those entering undergraduate programs in business management are likely to drop out before graduation' (ibid.). 


\section{Facilities for graduate students}

Doctoral students must be well-resourced to ensure quality projects and commitment to complete their studies. Access to qualified supervisors, academic materials, internet, online portals, computer labs, working space, and fieldwork budget, among other things, are necessary conditions for a successful $\mathrm{PhD}$ programs. Some Universities in the region are trying to avail such facilities for their $\mathrm{PhD}$ candidates. All universities have reported that they provide access to Journal Storage (JSTOR) and other online portals and indicated that it has allowed students to consult a wide range of articles and reading materials.

On the other hand, all case study universities indicated that the critical challenges of $\mathrm{PhD}$ programs have been predicated on lack of facilities and adequate funds. University libraries in Kenya have serious shortage of reference materials that can be used by $\mathrm{PhD}$ candidates. The library at The Catholic University of East Africa library has limited number of carrels distributed to graduate students at the stage of writing their theses and there is no a graduate student center where $\mathrm{PhD}$ candidates can meet and discuss issues and problems common to them. At the University of Dar es Salaam there is lack of good studying environment including office spaces, computer labs, and library facilities dedicated for PhD students. At Moi University there is lack of adequate staff that has hands on experience on computer based data analysis procedures to assist students, and there are limited resources to support learners' access to literature available across the world in their fields of research. In Sudan there is lack of proper facilities, e.g. lecture rooms, equipped labs, adequate libraries, etc. In the University of Zimbabwe there is lack of access to current literature in research methods and other subject based reference material for both lecturers and students. At Addis Ababa University there is shortage of up-to-date textbooks, journals and manuals in some specific fields. The following are the specific challenges regarding facilities for graduate students:

a) Networking and collaborative arrangement for sharing resources is absent in many universities. PhD programs are highly fragmented as each faculty or even each department runs its own PhD program. There is lack of exchange of staff, joint supervision of $\mathrm{PhD}$ candidates and sharing of academic resources among the universities in these countries. Moreover, except for a few success stories, the record of partnership arrangements among universities in the region or the south-south 
joint $\mathrm{PhD}$ programs in terms of sharing of staff and resources is not very impressive. In most of the cases the partnership between universities in the North and South is less sustainable and the success rate of South-South joint PhD programs is below expectation. Most of the North-South programs have also ended benefitting Northern universities more than their Southern partners.

A related study on 'ICT Infrastructure and Connectivity: New Capacity, New Opportunities' (Twinomugisha 2010) that reviewed ICT capacity in the SADC region universities concluded that the African Union (AU) and the European Union (EU) had started good and ambitious projects aimed at promoting networking for research and e-learning between African universities but very few had taken advantage of these initiatives; the quality of campus networks was low and most universities were unwilling to cooperate and collaborate. This unwillingness was keeping prices very high and bandwidth unaffordable especially for small universities. It has been also noted that in the SADC region there are high performance computer facilities in South Africa and Tanzania that can be shared by others in the region (Kondoro 2010, 28). But institutional cultures in the region still militate against resources and cost sharing.

b) Lack of a fieldwork budget is a chronic problem in most of the $\mathrm{PhD}$ programs. In some universities the $\mathrm{PhD}$ candidate has to bear all expenditures for the fieldwork. In others $\mathrm{PhD}$ candidates are only provided meager amounts of money. For instance at Addis Ababa University, a candidate is provided with USD 1,000 for covering all costs related to start and complete his research project including the cost of field work. The lack of funding also makes students conduct their fieldwork without the involvement of supervisors. Universities are also incapable of attracting large research funding (grants to students) from local and international sources.

c) Absence of venues for peer review of proposals and preliminary reports on findings, dissemination of research outputs, and lack of funding for publication in journals and converting dissertations in form of books are critical challenges facing PhD programs in Africa. In most universities very few social science theses are published. After graduation they are either deposited in the special reserve in the library or confined to shelves in the offices of the persons in charge of higher degrees. When one considers the investment that universities, donors, governments, communities and families pour into $\mathrm{PhD}$ training, the loss caused by the failure to put such knowledge into the public domain in form of books or articles in journals is immeasurable. Additionally, is the issue of funding which limits the capacity of universities to free supervisors from teaching and administration to give more time to 
graduate students. Lack of funding is also responsible for the absence of a forum for peer review processes of proposals and draft manuscripts, which leads to limited interaction between students among themselves, and between them and supervisors and other non-supervisory staff.

\section{The RESSESA Project - an initiative by OSSREA}

The RESSESA project seeks to address some of the above problems which are obstacles to the production of a sufficient number of high quality $\mathrm{PhD}$ graduates in most of the universities in the region. The general objective of the project is to fast track the production of a critical mass of researchers and academicians in the various fields of social sciences through supporting $\mathrm{PhD}$ training programs in universities of eastern and southern Africa. The specific objectives include:

- To augment the research capacity and skills of PhD. candidates through providing high level foundation courses, research methodology, writing skill, and soft skills;

- To enhance the investigation, collection and analysis of comprehensive and accurate fieldwork data on African reality;

- To facilitate timely completion of young PhD graduates;

- To improve PhD candidates' quality of research work and output through organizing workshops;

- To enhance the dissemination of the $\mathrm{PhD}$ research outputs through publication of books, journal articles, policy briefs and workshops;

The project does not intend to establish a new independent research school. Rather, by building on their existing $\mathrm{PhD}$ programs, it will perform the following:

- Forming a pool of senior academics from African universities, partner universities in the North and similar experts from the Diaspora, to develop and offer courses in research methods, disciplinary foundation or general courses in social sciences and humanities and to supervise $\mathrm{PhD}$ students during the whole period of study.

- Facilitating the mobility of this group of academics to enable them to offer these courses and provide supervision on the campuses of partner universities. 
- Coordinating the courses to ensure they are offered in a cost effective manner and supported by adequate incentives for staff and their institutions.

Creating a grant scheme for topping up support provided by the partner institutions and to enable students to undertake field research.

- Establishing a database of African dissertations in social sciences that will be accessed by all students and other researchers.

- Providing a platform for students to share their knowledge and peer review each other's work during research design and after field work.

- Facilitating platforms for students to share their findings with policy makers on issues relevant to the agenda of continental organizations, regional economic communities, and the agendas of national authorities

- $\quad$ Supporting students to publish some of their findings in regional scholarly journals before they finalize their theses.

In addition to the above activities the project will undertake some activities that are aimed at supporting the teaching and research functions while at the same time creating conditions for long term capacity for the graduates of the program to deliver courses at graduate level at their respective universities. These will include:

- Compilation of materials used for teaching into text books on research methodology and selected foundation or general courses in selected disciplines of social sciences.

- Commissioning the writing of text books based on Africa case studies to support graduate and under graduate teaching.

- Support for tool kits and manuals tailored towards specific skills in social and economic impact analysis.

- Establishing an online full access data base on African dissertations on social science known as OSSREA African Database of Dissertations in Social Science (OADDIS) that will contain $\mathrm{PhD}$ theses and dissertations on social science from all partner universities and will be made accessible on line to help students and other researchers.

RESSESA is not trying to replicate existing efforts but to add value to the same. Unlike many collaborative efforts it will not recruit students 
of its own or use one campus to organize all courses. RESSESA aims at providing all necessary services to those already enrolled in all the partner universities by offering research methodology and foundation courses and other necessary supports - supervision, fieldwork budget, peer review, publication and related services. All the activities will be done in collaboration with the universities.

RESSESA will have a three tiers management structure. The first is the Board of RESSESA, whose members would be Vice-Chancellors or their representatives from the partner universities. The Board will provide strategic leadership to the project and approve all its instruments, budgets and activities. The second tier is the Steering Committee of RESSESA, which would constitute the Directors of Postgraduate Studies or the Directors of Research of the partner universities. The steering committee shall be in charge of all the technical and scientific matters relating to the design, development, delivery, monitoring, evaluation and other matters related to the Program. Both the Board and the Steering Committee shall be supported by the OSSREA Secretariat with the Executive Director as the focal person. OSSREA will support the project by mobilizing the necessary human and financial resources, coordinating the activities and facilitating meetings and workshops. The OSSREA Secretariat will manage the project diligently under the supervision of the OSSREA Executive Committee and ensure adequate, timely and professional reporting to all stakeholders.

\section{References}

AAU (Association of African Universities). 2004. Higher education in Sub-Saharan Africa with ppecific reference uo universities. Accra, Ghana www2.aau.org/wghe/ publications/index.htm (Retrieved October, 20, 2012).

Adesina, J. O. 2006. "Global trends in higher education reform: What lessons for Nigeria." Journal of Higher Education in Africa, Vol. 4 No.1 pp1-23.

Africa. London: MacMillan Reference Ltd. www.codesria.org/IMG/pdf/01-ADESINA.pdf (Retrieved October 2012).

Altbach, P. G. 2006. International higher education: Reflections on policy and practice. Center for International Higher Education, Lynch School of Education, Boston College.www.bc.edu/content/dam/files/.../Altbach_2006_Intl_HigherEd.pdf. (Retrieved October 2012).

Assie - Lumumba N'dri, T. 2006. "Higher education in Africa: Crises, reforms and transformation." Senegal: Council for the Development of Social Science Research in Africa (CODESREA) working papers series. www.codesria.org/IMG/pdf/Ndri_ lumumba.pdf. (Retrieved October 2012). 
Bunting, I. and Cloette, N. 2012. Cross-national performance indicators. A case study of eight African universities. Johannesburg: Centre for Higher Education Transformation (CHET).

Gakusi, A-E. 2010. "African education challenges and policy responses: Evaluation of the effectiveness of the African development bank's assistance." African Development Review, Vol. 22, No. 1, 208-264. www.afdb.org/fileadmin /.../30768682-EN-1.3.4-GAKUSI.PDF (Retrieved October 2012).

Kondoro. J. 2010. "Africa connect: Concrete possibilities." in P. Kotecha (ed.), ICT Infrastructure and Connectivitiy: New Capacities, New Opportunities, SARUA Leadership Dialogue Series, Vol. 2 No.3.

Kotecha, P. et.a. 2012. Building higher education scenarios 2025: A strategic agenda for development in SADC. SARUA Leadership Dialogue Series. Vol.3. No.2.

Lulat, Y. G-M. 2005. A history of African higher education from antiquity to the present: A critical synthesis. Greenwood Publishing Group.

Mohamedbhai, G. 2008. The effects of massification on higher education in Africa www2.aau.org/wghe/scm/meetings/mai08/.../study_massification.pdf (Retrieved October 2012).

Mouton, J. 2011. The state of doctoral training in sub-saharan Africa: Statistics, analysis events. aau.org/userfiles/file/corevip11/ (Retrieved October 2012).

Robertson, Susan L. 2008. Market multilateralism, the World Bank Group and the asymmetries of globalising higher education: Towards a critical political economy analysis. Bristol: University of Bristol.http://www.bris.ac.uk/education/people/academicStaff/edslr/publications/27slr/(Retrieved October 2012).

Sall, E. 2004. "Alternative models to traditional higher education: Market demand, networks, and private sector challenges." JHEA/RESA Vol. 2, No. 1, 2004, pp. 175-210.

Boston College \& Council for the Development of Social Science Research in Africa 2004. www.codesria.org/IMG/pdf/7-SALL.pdf (Retrieved October 2012).

Sawyerr, A. 2004. "Challenges Facing African Universities: Selected Issues", African Studies Review Vol. 47, No. 1: 1.

Tefera D. and Altback P. G. 2003. Trends and perspectives in African Higher Education: An international reference handbook. Bloomington and Indianapolis:Indiana University Press.

Twinomugisha, A. 2010. Recent developments in ICT infrastructure and connectivity in P.Kotecha (ed), ICT Infrastructure and Connectivity: New Capacities, New Opportunities. SARUA Leadership Dialogue Series, Vol. 2, No.3.

World Bank. 1986. Financing education in developing countries: An exploration of policy options. Washington D.C.: World Bank.

World Bank. 2002. Constructing Knowledge Societies: New Challenges for Tertiary Education. Washington: The World Bank. 


\section{AFRICA GLOBALIZED? \\ MULTIPOLARITY AND THE PARADOXES \\ OF TIME-SPACE COMPRESSION}

\section{Preben Kaarsholm}

The Marikana massacre of 16 August 2012 - in which 34 striking mineworkers were killed by South African police at a platinum mine near Rustenburg - was described by protesters as a sinister return to the past, echoing the police killings at Sharpeville in 1961 that have become an icon of apartheid brutality and repression. According to its critics, the tragedy demonstrated that the African National Congress (ANC) government under President Jacob Zuma had become full circle in its inability to effect any substantial social and economic change, and had now shown its true face as an enemy of radical popular aspirations (see e. g. Kota 2012).

The question is, however, whether the Marikana shootings - and the events that led up and followed them - represented a return to the past or rather a flash-forward to a new multipolar and globalized world order, in which the powers of both government and of popular mobilization showed themselves as completely inadequate in the face of the dynamics and ravages of transnational capitalism.

Such a new global order had been emerging since the 1980s through structural adjustment and neoliberalism, the collapse of Soviet power and the demise of a 'second world' to match the 'first' and the 'third', the emergence of China as a new hegemon, and the intensification of transnational economic organisation brought about by Asian investment and competition. Its impact, however, was to some extent delayed or overshadowed in South Africa by the fall of apartheid, the democratic transition and development and growth in the immediate aftermath.

Marikana - like Sharpeville - became iconic because of the violence involved, and the ways in which was represented and repeated again and again across the world by visual media. But the imagery of the confrontation was made iconic also by the seemingly anachronistic and 'tribal' face of labor mobilization. Knobkerries, blankets, chants, and dancing were used to fortify and keep together and fortify 
the striking workers, and at the head of strike were Rock Drill Operators (RDOs) who strongly emphasized the identity of their masculinity as Pondo, Sotho or Shangaan. Also in this respect, the strike and the violence could be seen to represent a throwback to the past and to the evil old days of apartheid migrant labor and the use of tribalism to divide and rule (cf. Guy and Thabane 1991).

At the same time, the RDOs and the workers supporting their wild cat strikes, were moving into action against the guidance of the National Union of Mineworkers (NUM) and under the banners of a new break-away union - the Amalgamated Miners and Construction Union (AMCU). By doing so, they were turning their back an icon of modernization and the anti-apartheid struggle in the form of one of biggest and most important unions within COSATU - the Congress of South African Trade Unions - which under the leadership of Cyril Ramaphosa in the late 1980s and early 1990s had become a core member of the Mass Democratic Movement (MDM). This modern trade unionism - based on class consciousness and transcending traditionalist identities - had also, together with the South African Communist Party (SACP), become one of the 'tripartite' pillars of the ANC and thus of post-1994 majority democracy.

This monument of democracy and 'the struggle' was now taken on as an enemy of the people, and Cyril Ramaphosa - its former leader - castigated as an ally of international capital. Ramaphosa's Black Economic Empowerment (BEE) investment company, Shanduka, turned out to be closely involved with London Mining (Lonmin) - the owners and managers of the platinum mine at Marikana. Indeed, Ramaphosa himself was one of the South African directors of Lonmin, and in the early stages of the strikes at Rustenburg he spoke publicly of the need for law and order and firm policing of the violent wild-cat strikers (SAPA 2013).

The upsurge in worker mobilization was fuelled effectively by new populist politics and by politicians like Julius Malema - a dethroned and expelled former leader of the ANC Youth League - who toured the platinum and gold mining sites to which the strikes were spreading. Malema led the strikers and supporters in toyi-toying, calling for a resumption of the liberation struggle, and was joined in his support for the miners by a growing array of proclaimed civil society organizations which held the ANC government responsible for the tragedy, and called for the nationalization of the mining industry. 
All this fed into the campaigns and positioning that preceded the ANC's Mangaung conference in December 2012, in which the leadership of the dominant party would be elected and configured, and thus effectively also the future president of South Africa. The Marikana upheavals stimulated the expectations of Malema for a triumphant return to the ANC as well as the aspirations of a more widespread and loose alliance of ABZ - 'Anything But Zuma' - caucuses. All this, however, was eventually countered very effectively by bringing Ramaphosa onto the stage as Vice-Presidential partner for Zuma's candidature. In this way, Ramaphosa returned to politics as a likely ANC presidential candidate for a future round of South African elections in 2019, thus making up for his bitter experience of being outmanoeuvred by Thabo Mbeki as successor to Nelson R. Mandela, and his exiling into big BEE business (Munusamy 2012; cf. Butler 2008).

In the meantime, the wave of wild-cat strikes and new radical worker mobilization had both continued and been successful in getting Lonmin, Anglo-American and other transnational mining corporations to concede to substantial wage increases of up to 22 per cent for the striking Rock Drill Operators. These concessions, however, were accompanied by simultaneous sackings and reductions of the work force as well as by threats by Anglo-American to mothball or close down mines altogether, and move its business elsewhere. The argument was that if the ANC government wanted the platinum and gold mines to be run for reasons of employment creation, rather than of profitability, they might then as well go ahead and nationalize the mines, like Julius Malema and his supporters demanded. Mining for business purposes could then be continued more profitably in Asia, more pliable African countries, or elsewhere in the world, where strikes and labor unions were not a problem.

Having initially responded angrily by accusing the mining companies of absconding after having stolen national natural resources, the ANC government eventually opted for negotiation, and formally and definitely proclaimed nationalization to be an issue belonging in the historical past. What will be the outcomes of negotiation, however, is not clear, but the Government side obviously has some level of clout in controlling access to platinum reserves that are scarce globally. Otherwise, the mining companies and transnational capital seem very much to be in the drivers' seat, and not matched at all in their powers by either state regulation or trade unions. As to the latter, features of new 
labor organization and radical mobilization that were described above as having semblances of the past, may very well instead represent the outlines of an emergent future.

The Marikana massacre and the South African mining strikes provide a useful occasion for us to rethink what globalization involves for Africa - what are the effects of multipolarity in terms of both politics and economy, and what are the correspondences that exist or do not exist between globalization and the emergence of new forms of modernity within and between African societies?

The coincidence of globalization and the 'third wave' of democratic transitions that swept the world after 1989 - including the fall of South African apartheid in 1994 - led to optimistic understandings of globalization as an intensification of development and modernisation. It would include an undermining of former empires and old western and northern hegemonies, based on colonial domination, and would free the oppressed economic and cultural economies of the former South and the Third world. Globalization would make space for alternative modernities to emerge that had been stunted by earlier strategies for development, which were limited in the sense of serving primarily the interests of the North and of the United States and the former European colonial masters.

In this perspective both more recent development and ANC programmatic discourse has tended to see South Africa as a powerhouse of African modernization and catching up. This is exemplified in NEPAD, the South African driven African Union framework of a 'New Partnership for African Development', in its active leadership in peace-keeping operations from Burundi to the Côte d'Ivoire, in its support for the Timbuktu library of early African scriptural culture (recently threatened by Islamist purification), and maybe most tangibly and directly in the way South African investments, media and consumer culture have been permeating other African countries from South to North and East to West.

South Africa has been an engine of growth in Africa both internally and externally, and it has emerged alongside Brazil, Russia, India, and China as a new BRICS player within the changing multipolar global order. In terms of growth, South Africa's mixed-economy policies have worked well, but have been much less successful in social terms in their inability to attack unemployment and the loss of jobs. In spite of this, South Africa's very basic welfare policies offer a foundation for 
social citizenship, which is absent in other African and developing countries (cf. Lund 2012).

In this sense, a South African 'model' for development in Africa has been allowed to unfold in the aftermath of apartheid, which is social democratic inasmuch as it is mixed-economy-oriented and seeks to reconcile policy ambitions of stimulating growth and redistribution. The ANC's economic policies after 1994 have thus so far managed to sustain rather stable rates of growth with a policy framework that has been fluctuating from RDP - the Reconstruction and Development Programme - through GEAR - Growth, Employment and Redistribution - to the more recent NGP - New Growth Path - and NDP the National Development Plan 2030. In the ANC government's own words it has aimed at adjusting spending to available income, and establishing a 'virtuous cycle of savings and investment, economic participation and sustainable job creation, infrastructure development and skills upgrading' (National Treasury 2011, 17).

There are signs, however, that the South African model of combining growth with at least a minimalist basis for social citizenship - is coming under threat from global competition and the increasingly unbounded and efficient mobility of transnational capitalist enterprises. Thus the way in which the mining strikes and management responses have been unfolding may well be an indication that parts of the industrial basis for South Africa's economic strength are weakening, and that even the basic traces of social welfare and the modest wage levels generally available to South African workers in employment are becoming uncompetitive. As far as mining is concerned, labor costs and productivity constitute the only area of 'core competitive advantage' (Hartford 2012, 2).

The Marikana tragedy and events unfolding around the miners' strikes have provided sudden, sharp insights into new life worlds and labor relations emerging in rural settings, far from the institutions and networks of urbanism that have traditionally been associated with modernity (cf. Ferguson 1999). Some aspects of these life worlds around industrial 'growth points' in the South African countryside are well known from e. g. Gill Hart's work on Taiwanese investments in textile (Hart 2003) - ventures that would now no longer have any profitability - or from Mark Hunter's work on aids, sexuality and masculinities in the sprawling settlements surrounding rural industrialization in KwaZulu-Natal (Hunter 2010). 
Marikana and the mining strikes have now brought to the fore the extent to which similar life worlds and conditions for labor strategies have become widespread also within the mining industry - a core area of South African industrialization and modernity. They have also demonstrated the fragility of many of the foundations for unionism, on which central institutions of progress like the National Union of Mineworkers have based their expectations and tactics (Breckenridge 2012). Central to this is the persistence of migrant labor - something which in 'classical' modernization theory - as well as in 'classical' ANC political thinking - would be a 'transitional' phenomenon, bound for extinction with the full unfolding of urban, industrial, class-based modernity.

Migrant laborers were centrally placed in the violence of the final phase of the disintegration of apartheid in the late 1980s and early 1990s. The labor hostels of the Rand and KwaZulu-Natal were major battlegrounds between the modernizing unionism of the NUM, COSATU and the United Democratic Front (UDF) on the one side, and the ethnic nationalist unionism supported by the Inkatha Freedom Party (IFP) through UWUSA, the United Workers' Union of South Africa. Ethnic unionism - on the other hand - was based on a long history of the use of tribal divisions as instruments of mining management, with hostel accommodation overseen by indunas (headmen) provided for workers from different backgrounds as a central ingredient. The success of the NUM and COSATU in handling this was an important contribution to the consolidation of ANC power and governance after 1994 and to the overcoming of apartheid multiculturalism.

The dismantling of apartheid led to the phasing-out of the mining hostel system, with mine workers being offered different levels of cash allowances to replace accommodation and other forms of in-kind welfare remuneration included in the old system of management (Bezuidenhout and Buhlungu 2011; Hartford 2012; Breckenridge 2012). Such cash allowances soon came to be seen and spent as part of a general wage received, with workers spending as little as possible on accommodation, and with new geographies of informal settlements mushrooming around the mining sites and their infrastructure. These include not only miners' dwellings, but are also home to multitudes of hangers-on - wives, prostitutes, providers of services and goods, and a new precariat of people seeking for just a ghost of an opportunity for employment or income generation. Family structures were also 
changing with migrant labourers on the mines increasingly having to support two families instead of one extended family - one at the work place and one in the village (for a mapping and illustration of such geographies, see Bezuidenhout and Buhlungu 2011, 253).

Old hierarchies of work organization would persist in a less racialized format with some classes of 'worker' requiring education skills well beyond the reach of most Africans, such as e. g. those involving blasting certificates and requiring literacy and education. Rock Drill Operators - RDOs, the category of workers at the centre of the current wave of strikes -have remained a relative elite among the illiterate mineworkers, but one whose interests had been neglected by NUM wage negotiators. $\mathrm{RDO}$ earnings would perhaps be something like $\mathrm{R}$ 10,000 before the strikes and maybe R 12,000 following the strikes, if employment was continued, including allowances for housing and amenities. At the lower ends of the spectrum are then masses of workers earning half of this or much less, with less skilled categories of labor being to an increasing extent supplied by contractors (cf. Breckenridge 2012).

While the crisis of unionism among the mineworkers has most directly concerned relatively skilled, but literate groups of workers like the Rock Drill Operators - with the RDOs at the Rustenburg mines turning their back on the NUM to join the more activist AMCU contract labor represents a much more fundamental crisis. For these 'Kolonnenarbeiter' there is no contractual relationship with the mining management as such, but only with the various private labor supply agencies, and unionizing is not on the agenda. In this respect the South African gold and platinum mining labor market is exposed to a set of trends and impacts that are global and have the same effects of driving down the cost of labor in South Africa as it has in Denmark, Qatar, the United Kingdom, Russia or Bangladesh.

The historical legacy of migrant labor in South Africa, however, means that these global trends - or impacts of globalization shared with other parts of the world, and thus representing in David Harvey's and Roland Robertson's terms a scenario of 'time-space compression' - act themselves out in particular ways (cf. Harvey [1980] 1989, Part III; Robertson 1992, 8). The ethnic face of the Rustenburg strikes - shown on global television screens in images of the Marikana 'mountain' with scores of workers with blankets, knobkerries and other 'tribal' insignia, supported by their women and affiliates - thus 
represented a resurgence or reconfirmation of the historical dominance of certain regions and groups (predominantly Pondo, Sotho and Mozambican Shangaan) in terms of having special qualifications and entitlements to RDO positions. RDOs thus continue to live in dual worlds - the majority of the year being spent on the mines, and much shorter periods round Christmas and Easter with their rural families and villages (Hartford 2012, 3).

For contract laborers and the unemployed hangers-on of the precariat of the mining shack lands, ethnicity and belonging are also essential, with groups of unskilled migrants being recruited and bussed in from labor-hungry rural areas. In both cases poverty and super-exploitation are important for their short-term expectations of profitability. But in contrast to the apartheid past these relationships now play themselves out without the social responsibilities being actualized of which the earlier system of hostels and compounded labor was representative (Bezuidenhout and Buhlungu 2011; Breckenridge 2012). Instead new varieties of neo-liberalist exploitation and management have been emerging, which make South Africa more like other African countries and economies than the 'exception' it used to be seen as or take pride in being. And increasingly having to compare itself to and compete with systems of control, recruitment and expectations of profitability as they are unfolding e. g. on the Zambian copper mines under Chinese management.

In this way, not only does space contract in the sense that differences between South Africa and other parts of the globe are diminishing. Past and future also draw closer to each other, e. g. in the ways in which the emerging regimes of neo-liberal labor relations are paradoxically capable of drawing strength from the super-regulated authoritarianism of Grand Apartheid and its construction of ethnic homelands as reserves of cheap and docile labor. What is different from the past is that the rural-based labor force and its discourses of belonging are not docile, but rebellious - of which there were of course also important instances in the past (see e. g. Badat 2013). But also that their rebellion takes place within a democratic framework led by an ANC government with a trade union-based, mixed-economy and social democratic ideology and agenda as demonstrated in the 'responsible' fluctuations between public spending, tightening-the-belt, and opening up for renewed spending of the RDP, GEAR, NDP, and NDP 2030 policy frameworks mentioned above. 
Cyril Ramaphosa as Deputy President of the ANC and future Vice-President and highly likely future President also of South Africa is in many ways an embodiment of all these blendings, contradictions, and expectations. Ramaphosa represents both the upsurge in labor organization, which helped to bring about the democratic transition and the foundations of ANC power, but also Black Empowerment business, management and capitalist enterprise. The big question this puts on the agenda - in South Africa as in Greece, France or Denmark - is whether social democratic union mediated governance and regulation are at all possible and thinkable within a globalized framework, and thus to what extent the NUM and COSATU can remain pillars of support for an ANC government.

Whether such a government with the charismatic Ramaphosa at the side of and eventually replacing the less charismatic Jacob Zuma will be able to mediate between global capital and local labor remains an open question. This will involve mediating also between Black Economic Empowerment within South Africa and a new unionism that is capable of representing a wider spectrum of workers as well as the interests of the members of the growing precariat of unskilled contract laborers and the masses of the unemployed. As far as the development of such a new unionism is concerned, the NUM and COSATU have shown their limitations, opening up space for the emergence of wildcat unions like the AMCU and for challenges of populist and delivery protest politics. The next year or two will show to what extent they will be able to adjust and make up for this by becoming more inclusive in their representation of interests, and whether this will be possible within the framework of a continued partnership with the ANC.

\section{References}

Badat, Saleem. 2013. The Forgotten People: Political Banishment under Apartheid. Leiden: Brill

Bezuidenhout, Andries and Sakehla Buhlungu. 2011. "From Compounded to Fragmented Labour: Mineworkers and the Demise of Compounds in South Africa." Antipode, 43: 237-263. doi: 10.1111/j.1467-8330.2010.00758.x

Breckenridge, Keith. 2012. "Revenge of the Commons: The Crisis in the South African Mining Industry." History Workshop Online, November 5. Accessed 12 March 2013. http://www.historyworkshop.org.uk/revenge-of-the-commons-the-crisisin-the-south-african-mining-industry/

Butler, Anthony. 2008. Cyril Ramaphosa. Oxford: James Currey. 
Ferguson, James. 1999. Expectations of Modernity: Myths and Meanings of Urban Life on the Zambian Copperbelt. Berkeley: University of California Press.

Guy, Jeff and Motlatsi Thabane. 1991. "Basotho Miners, Oral History and Workers' Strategies." In Cultural Struggle and Development in Southern Africa. edited by Preben Kaarsholm, 239-258. London: James Currey.

Hart, Gill. 2003. Disabling Globalization: Places of Power in Post-Apartheid South Africa. Berkeley: University of California Press.

Hartford, Gavin. 2012. "Migrant Labour System Lies at the Heart of Mine Unrest." Downloadable from Engineering News, October 8. Accessed 12 March 2013. http://www.engineeringnews.co.za/article/migrant-labour-system-lies-at-heartof-mine-unrest-hartford-2012-10-08

Harvey, David. [1980] 1989. The Condition of Postmodernity: An Enquiry into the Origins of Cultural Change. Oxford: Basil Blackwell.

Hunter, Mark. 2010. Love in the Time of AIDS: Inequality, Gender and Rights in South Africa. Bloomington, IN: Indiana University Press.

Kota, Ayanda [spokesperson of the Unemployed People's Movement]. 2012. "The Marikana Mine Workers' Massacre - a Massive Escalation in the War on the Poor." Posted on AbaHlali baseMjondolo web site August 18. Accessed 12 March 2013. http://abahlali.org/node/9035

Lund, Francie. 2012. "Children, Citizenship and Child support: The Child Support Grant in Post-Apartheid South Africa." In Registration and Recognition: Documenting the Person in World History, edited by Keith Breckenridge and Simon Szreter, 475-494. New York: Oxford University Press.

Munusamy, Ranjeni. 2012. "Cyril Ramaphosa: The Return of Nelson Mandela’s Chosen One." The Guardian, December 20. Accessed 12 March 2013. http://www. guardian.co.uk/world/2012/dec/20/cyril-ramaphosa-return-nelson-mandela

National Treasury, Republic of South Africa. 2011. Budget Review 2011. Pretoria: Communications Directorate. Accessed 12 March 2013. http://www.treasury.gov. za/documents/national\%20budget/2011/review/Budget\%20Review.pdf

Robertson, Roland. 1992. Globalization: Social Theory and Global Culture. London: Sage.

SAPA [South African Press Association]. 2013. "Ramaphosa: Call for Action and Marikana Tragedy Not Linked.” Mail \& Guardian, January 9. Accessed 12 March 2013. http://mg.co.za/article/2013-01-09-ramaphosa-call-for-action-and-marikana-shootings-not-linked 


\section{'THE ROAD TO SUDAN, A PIPE DREAM?' KENYA'S \\ NEW INFRASTRUCTURAL DISPENSATION \\ IN A MULTIPOLAR WORLD}

\section{Mark Lamont}

While recent investment in Africa's infrastructure takes pride of place in many glossy magazines, exemplified by African Business, touting the success or attractiveness of this or that African country, academic field researchers move more cautiously to respond to such projects in their depictions of recent transformations across the continent. Part of this slow pace may be a well-reasoned 'wait and see' approach, characteristic of methods that see events as fateful, thus anticipating rather than presuming their outcome, but there is also a historicized blind-spot towards examining infrastructure and, hence, its politics in Africa since colonial times (see Larkin 2008). And yet, 'Infrastructure Now!' seems to be a clarion call across Africa, with unprecedented co-operation between nation-states, alternative forms and sources of financial investment, all generating new stakeholders and regulatory frameworks that depart from those of the recent past. James Ferguson's (2006) trope of Africa's oil-drilling platforms and exclusive game-parks as 'global shadows', owned and operated by foreign capital and corporations, however instructive in grasping the neo-liberal reforms of the 1990s, now seems overtaken by events as the 'point-to-point connectivity' in contemporary African countries has been enhanced by an aggressively framed drive to robustly expand infrastructure at all costs.

This is a moment of risky conjuncture in Africa that should command our attention, but it is also one that is generative of new theoretical perspectives. In this chapter, the focus is Kenya's new infrastructural dispensation and this is explored through the analytic and political value of speed embedded in that nation-state's most recent development planning, "Vision 2030". As a case study to examine, from an admittedly macroscopic perspective, the chapter turns to some of the controversy and challenges facing a long-awaited project aimed at linking and transporting Sudan's considerable oil reserves to refineries located on Kenya's northern coast and outwards onto the oceanic shipping lanes of the western Indian Ocean and China's industrial southern coast. 
Much of the writing about the so-called '21st century scramble for Africa' tends to be either celebratory or suspicious in tone when considering the pivotal and relatively recent role of Chinese investment, technocratic aid, and commercial presence on the continent (see Brautigam 2009). Whatever the multiple reasons for this stance towards the Chinese involvement in building superhighways, informational technologies, or mega-ports in Africa, its costs to understanding the dynamics of national and regional development, as well as the shifting international relations orchestrating these investments, are considerable with respect to the myriad perspectives on how African development is understood, from outside the continent, as well as within. In the European media, an iconography of an earlier historical period continues to hold sway, even though African development seems poised on the cusp of a new 'infrastructural dispensation', a term loaded with significant ideological meaning and political consequence. Moreover, the term indexes an idea that the aspirations and dreams of the first postcolonial decades were not utopian, but somehow achievable without sacrificing too much dignity. How can the image of malnourished African children, or endemic bloody conflict be broken by the counter-image of port-to-rail containerization and the flood of affordable Chinese motorcycles, or the laying down of fiber-optic cables and the launching of new satellite television services? Infrastructure is important precisely because focusing on it consists of an act of iconoclasm. It peels back the tarmac to reveal the gravel below and the aspirations that run along it. To borrow from Brian Larkin's (2008) suggestion that earlier European representations of Africans' usage of technology conveyed a 'colonial sublime', this chapter questions European ambivalence to Africans' desire for technology and infrastructure, mirroring fears implicit in their views towards the Chinese, particularly on matters concerning the scale of the Chinese economy and its pollution to the environment, its own human rights abuses, and its motives for being in Africa. These are extremely complex questions, and certainly beyond the scope of this chapter, but the present conjuncture deserves a repositioning of African studies through examining what is at stake for Africa in a multipolar world, where the sources of international investment and governance are no longer restricted to European and American political-economic hegemony.

The problem is one of finding one's ideological feet in the shifting sands of Africa's current tide of economic growth where, beyond 
the hype of Afro-pessimism that dominated discussions only a short while ago, the consequences of Africa's place in an increasingly multipolar world may have some startling effects. One of these effects may be the form that conflicts take around both large-scale and smaller infrastructural projects. While this contribution is not ethnographic per se, it approaches the question of the role of Chinese investment in Kenya's recent policy of "Vision 2030", a highly ambitious technocratic program of economic growth based on maximizing infrastructural construction and operational capacity.

\section{“Vision 2030"}

Although postcolonial Kenya has seen a succession of development targets come and go, beginning with Development Plans roughly corresponding to five year parliamentary sittings, "Vision 2030" is the most ambitious of these in the five decades of political independence from Britain. Designed as a follow up on the "Economic Recovery Strategy for Wealth and Employment Creation" (ERS) of 2002 - President Mwai Kibaki's major recovery from the dismal economic performance of the 1990s - "Vision 2030" is largely the product of a consultative process involving Kenyan citizens on three social, economic, and political 'pillars' - each component seen as crucial to the fulfillment of making Kenya a "middle income country providing high quality of life for all of its citizens by the year 2030" (Republic of Kenya 2007: p.?). A sustained 10 per cent growth in Gross Domestic Product (GDP) is its stated goal, but "Vision 2030" also must contend with severe challenges in terms of the social inequities facing citizens from different regions and how these political and economic disparities are experienced by people occupying different class positions and livelihoods. With a large proportion of people working and earning a living from lightly regulated economic activities, the government plans to heavily reform the 'informal sector' with yet-to-be seen consequences upon key sectors, including transportation.

One of the most ambitious components of the 2002 ERS was the rehabilitation of existing communications and transport infrastructures. Road building took priority over the decade of 2002 to 2012, culminating with massive rural road programs and the construction of the eight-lane Thika-Nairobi superhighway, built by Chinese engineering consortiums Sino-Hydro, Sheng $\mathrm{Li}$, and China Wu Yi. Soon 
to be nicknamed with the sobriquet, the 'Chinese Road', this highway in many respects reveals the novel face of development financing, with US $\$ 360$ million being raised and invested by the African Development Bank (AfDB) and an additional section of the road being paid for by a concessional loan from the Exim Bank of China, the balance being met with revenue from the Republic of Kenya itself. This pattern of funding is significant in two respects. The first concerns the source of enormous national debt Kenya incurred during its first two post-colonial decades, much of this owed to American investors and the World Bank, damagingly resulting in the long period of fiscal austerity that precipitated neoliberal reforms in the 1990s. Secondly, Kenya's impressive infrastructural renaissance, sorely overdue after the stringent constraints and damage of structural adjustment programs that characterized the antecedent government dominated by KANU (under President Daniel arap Moi) succeeded through appeal to a new world of multipolar financial and corporate lending, including 'non-traditional' sources of investment, mainly Chinese. In the space of about a decade, Kenya would see more and more paved roads, transforming transport throughout the eastern African region, while reshaping in dramatic form the landscapes and livelihoods of many parts of the country.

It would be difficult to overestimate the economic impact of Kenya's new infrastructural dispensation. There are several qualities about this moment that demand our attention. One is certainly the robust investment in road construction and, hence, Kenya's strategic commitment to automotive transport. This East African country has imported a stream of vehicles - mainly second hand Japanese vehicles from markets in Dubai - at such a rapid rate that, at one time in the past years, there were gluts in the availability of license plates to meet the demands to insure and regulate this new influx. Sedan style cars and medium-capacity lorries are among these second-hand vehicle imports, but increasingly it is Chinese-manufactured motorcycles that are becoming most popular among individual entrepreneurs aiming to operate motorcycle-taxis (boda-boda). Because these boda-boda frequently ply semi-rural routes that are under-policed and can rival larger combi-vans (matatu) during traffic congestion in built-up urban areas, it is a particularly difficult form of public transport to regulate. This development has exacerbated attempts to reduce the road deaths and injuries that result from this particular form of transport. 
The imperative to build new roads is, in part, a working response to the greater availability of personal lines of credit, allowing Kenyan consumers new access to vehicle ownership. Despite efforts by Kenyan Customs to certify that vehicle imports are less than five years (for reasons as much to do with insurance premiums and taxation purposes, as they do with vehicle and road safety), serious issues face commuters in urban areas, not only restricted to the ironically named 'rush hour' traffic of cities like Nairobi and Kisumu, when traffic is stifled by congestion, but also harnesses grave concerns for the overall rise in the number of Kenyans who lose life and limb on this country's roads. Road construction is, however, a central and realizable goal of "Vision 2030" and efforts to develop an independent Kenya National Road Safety Authority (KNRSA) to mitigate the worst effects of this increase in traffic have been linked up with networks of experts and activists associated with the UN Decade of Action for Road Safety to develop strategies for reducing road death and injury.

The second most significant quality of Kenya's new infrastructural dispensation is the new value of speed in a nation-state determined to become a 'middle-income' country by 2030. "Vision 2030" is about speed in many respects, whether that is the march of maendeleo (moving forward, or 'development') towards a yet-to-be-realized and abstract goal of regulating both mobility and financialization into an integrated system; or, the more generalizable ideology of neo-liberalism's penchant for speed, exemplified by David Harvey's discussion of Chinese attempts to build an interstate highway system larger and more extensive than that built in the United States in a period of just fifteen years (Harvey 2005: 132). The analytics of speed in Africa have been explored elsewhere, with Rosalind Morris attempting to interpret the value of speed for South Africans in the way that it is seen as a vehicle for political transformation, and a way of looking at the future, speed being described in the South African scene as the "irresistable handmaid of circulation and financialization" (Morris 2010: 590). The Kenyan context begs a few comparisons to Morris' depiction of South Africa, but here it must be suggested that speed's connection with political transformation must also be regulated by the state, as is the case of massive crack-downs on illegal public service vehicles (PSVs) that periodically occur, the enforcement of vehicle installation with 'speed governors' and tachometers, as well as the actual reality of mobility in most Kenyan towns and cities, which crawls to a near-halt 
during hours of peak traffic load. Speed does not necessarily mean a consistent and exponential speeding-up, but it also inclusive of the stops-and-starts that characterize motorized transport in this country, exemplified perhaps best by the ubiquitous and avaricious presence of road-blocks erected by police (see Lamont 2012). It is this kind of discontinuous speed that characterizes many experiences of transport in Kenya and not just along the line of the road. In the Kenyan context speed is valued above all by "Vision 2030"s attempt to integrate many currently disjunctive aspects of the overall transportation system from ocean port to rural kiosk.

The value of speed becomes slightly more empirical in the complaints of many eastern African business people about the waiting and expensive surcharges that characterize any attempt to import commodities through the Indian Ocean port of Mombasa. With an overload in its capacity to process goods and containers, its expensive moorage fees, the Kenya Port Authority (KPA) has been criticized severely by a range of importers from within Kenya, but importantly also from those living in Uganda, Sudan, and other countries dependent on this major port. The Ugandan daily newspaper, The New Vision, frequently carries stories about the effects of increasing costs incurred at Mombasa Port in security and marine services, pilotage and tug facilities, dockage and wharfage costs - not to exclude customs and excise - with one representative of the Uganda Shipper's Council, a lobby group, making an appeal to increased privatization of services at Mombasa Port:

Why should the KPA continue to collect dues for wharfage, and handle cargo, yet KPA are the landlord at the Mombasa Port. This tender should be given to private players to enhance competition and bring down rates (Sanya 2012).

Rwandan traders complain that the additional days it takes to clear their consignments is tantamount to discrimination on the part of the KPA and the Kenya Police who, it is reported, frequently extort Rwandan truck drivers along the Northern Corridor, the main road network linking the Indian Ocean to the Great Lakes region (Ngarambe 2013). It is now a firmly established opinion and research based argument that 'doing business' in Africa is expensive, particularly with respect to freight and haulage transport costs and the additional expenditure on petrol (Pederson 2001; Teravaninthorn and Raballand 2009). With high transport costs and big dreams, eastern African entrepreneurs 
are keen to accelerate the speed to which they can do business and turn a profit. "Vision 2030"'s infrastructural elements are designed to get things on the move, at speeds that are measured in ideological as well as kinetic ways.

Without a doubt, "Vision 2030" is ambitious and its actualization will have effects through the eastern African region and beyond. While Kenya seems certain to retain its interests in the region's transportation system through territorial control over the main ports and transit corridors, it is not content with the disjunctive pace (slow then fast) and dangerous infrastructural overload that constrains public and commercial transport at present (see Lamont 2013).

Three major infrastructural mega-projects are planned to facilitate a neo-liberal vision of trade in the region: the rehabilitation of the Northern Corridor, linking Kenya to the Great Lakes regions of Uganda, Rwanda, Burundi, and the eastern Congo; a planned second port on the Indian Ocean, at Lamu, long since eclipsed in economic and political importance to Mombasa; and the ever ambitious and controversial project aimed at opening up commercial transport to destinations in Ethiopia, South Sudan, northern Uganda and, possibly, into the land-locked Central African Republic. One imagines Kenya's sovereignty and position in the region to be greatly buttressed by its singular access to the Indian Ocean, rivaled only by its southern neighbors in Tanzania, but very serious political conflict threatens this dream and raises the question whether it will echo the significant economic transformations seen in other parts of the globe, such as India and China. So politically significant has been the plan to build road, rail, and oil pipelines to Sudan that rumor abounds that the reason the Kenya Defence Force (KDF) invaded Somalia in 2011 was to achieve 'security' within the larger regional context and, hence, expanding Kenya's sovereignty beyond its borders through this 'gift' of infrastructure.

At the heart of Kenya's drive to build road networks is a historical reliance on the automobile for most transportation, even though railway dominated the colonial period and discussions about rail infrastructure continue to be heard in planning missions. It would be hard to overestimate the challenges of regulating automotive transport and its future impact on the political-economy of the region, not to eclipse the potentially dangerous cost in human lives and injury resulting from road traffic accidents, already at an alarming scale (see Lam- 
ont 2010; Lamont 2013a; Lamont 2013b). Huge challenges face the regulation of mobility, not only in Kenya, but throughout the region. This is especially the case considering the longer history of smuggling and tariff evasion, known generically as magendo, an evasion of state law enforcement that is a staple point of debate in national legislation. The new mega-port at Lamu, for instance, was planned to be a Free Port, expediting the circulation of containers and their contents without the extensive scrutiny of customs officials, a major concern in this northern region where armed conflict and banditry have historically plagued local populations. The availability of ever more small-arms in the region could have disastrous further effects. As such, conflict lies at the heart of these infrastructural projects and raises major concerns about patterns of land-grabbing, violence, and other forms of expropriation that worry the region's inhabitants.

If proponents of this 'infrastructural renaissance' in Africa point hard at the high costs of transport in Africa - one of the strongest ideological statements made in celebrating this dispensation - these are typically narrowly defined as economic costs. The 'event' of Kenya's rebuilding and its often lauded success in expanding 'the economy', marveled at with respect to ' $4 \%$ growth', is bound up in a much longer duration of economic volatility and social strife, witnessed in almost every single historical election period. The human costs, on the other hand, remain indiscernible, beyond the scope of the economists and their consultants. With the 'growth' in mobile communications, new ocean ports, fiber-optics, banking technologies, new super-highways, this human cost is most difficult to measure and compare with economically defined costs. This technocratic logic is heatedly at odds with many of the political discussions being held where these roads and cables are to be laid. In what follows, we take up the story of controversy surrounding plans to build the most ambitious infrastructural project in Kenya ever, known as LAPSETT, a project that will have a major impact on the northern regions of the country and its coastal port, but most likely well beyond the borders of Kenya itself, transforming local communities and revealing a very contentious, conflict ridden set of political issues and challenges. And, it is to LAPSETT that we turn to as a case study of "Vision 2030"'s more palpable effects on ordinary Kenyans. 


\section{LAPSETT (An Acronym to Die For)}

The following discussion of Kenya's new 'infrastructural dispensation' centers on a controversial new development project in the north of Kenya: the Lamu Port - South Sudan - Ethiopia - Transit Corridor (LAPSETT). Its controversy lies in two main points of historical contention and conflict within northern Kenya from coast to interior.

The first is the long-standing grievances of the peoples of the north with respect to their political and economic marginalization since colonial times. Its elected leaders historically lobbied for a major road network and for economic development, but were systematically bypassed by Kenya's half-century of post-colonial development planning and investment. The vulnerabilities of pastoralist communities in the arid north owing to the scarcity of water and pasture for their animals, the ubiquity of insecurity within the region linked to a complex of cattle raiding and banditry, and the palpable political indifference to their voices of protest by proponents of LAPSETT have set into motion a flurry of activism that commands attention to the north's importance to regional security and development.

A second point of contention concerns coastal communities and, in particular, the Swahili-speaking peoples of the Lamu archipelago and its environs, whose livelihoods and identity is widely felt to be threatened by the massive construction of a megaport and oil refinery. With its long history of cosmopolitan connections to the "global worlds of the Swahili" (see Loimeier and Seesemann 2006), this entrepôt of the western Indian Ocean, once rivaling Mombasa in economic and religious importance, experienced various periods of decline, sharply with British colonialism, then in a protracted sense under Kenyas postcolonial governments. LAPSETT intersects these highly complex politics of northern Kenyan development in ways that are revealing of the longer history of the region as a whole. And it is into this complex political drama that the Chinese - who are key stakeholders in LAPSETT - have entered not only as investors and technocrats, but also as cultural bricoleurs, intent on carving out their own 'special relationship' with the northern Swahili coast of Kenya through the invention of a tradition reaching back - implausibly some would say - some six hundred years ago.

The northern Kenyan island of Pate - one of two inhabited islands in the Lamu archipelago - came to worldwide media attention in 2005 
through a news story that has the tenor of an apocryphal tale. After nearly half a decade of increased investment in Kenya's infrastructure, Chinese officials arrived at Siyu (a small but historically important town on the island) in search of the descendants of Chinese sailors reported to shipwreck on this coast, it was held, following the famed navigator Zheng He's visit to the Swahili coast in 1415 C.E. of Pate's residents, a nineteen year old girl, Mwamaka Sharifu, described as having 'almond shaped eyes' and purported to be a descendant of these seaman by Chinese sources, had little idea how her life would become entwined with a newly supported legend about China's ancient ties to the region. While the story has since generated great controversy and disagreement, not only in the media storm which surrounded this 'state visit' to the tiny town of Siyu on the small island of Pate, but also in terms of the politics of a multipolar world and the place of the Lamu archipelago in its manufacture in the western Indian Ocean over the longue durée.

This noteworthy encounter with the Chinese in Kenya exemplifies the symbolic valences of China's renewed relation with African states, particularly through the People's Republic of China's (PRC) 'gift' of infrastructure to the continent as a whole. In a state-sponsored celebration of Zheng He's 600th anniversary of his fleet's circumnavigation of the western Indian Ocean, Chinese visitors to Pate sought out families imagined in local folklore to have been descendants of shipwrecked sailors of Zheng He's fleet. Cutting the hair of Mwamaka Sherifu's mother for its DNA in 2002, these visitors promised to reveal the genetic connection between Africans and Chinese, something residents of Pate have waited in vain for these anticipated results. And the story of Mwamaka, now a Chinese-trained physician, is further twisted into a highly ambitious underwater archaeological project aimed at recovering remnants of the vessel which sank almost 600 years ago. As an ideological project, the Chinese government's interest in affirming this connection with the northern Swahili coast, asserting China's place in this maritime nexus of the western Indian Ocean - inclusive of a succession of incursions by Yemeni, Omani, Portuguese, Gujurati, British, German colonists - is a bold diplomatic bid for recognition of China's highly visible investment in revamping Kenya's economy through the construction of primary infrastructure: namely, one of the most ambitious development projects to be undertaken in Kenya's five decades of political independence: LAPSETT. 
The port town of Lamu is set to be home to a new Free Port that would overshadow that of Mombasa, a reversal of political positions not seen since the 17th century rise of the Omani sultanates of Zanzibar and their hegemony of the Kenyan coast. This sense of history is very much on the minds of Lamu's residents, many of whom see the building of the mega-port as a threat to their cultural identity, the status of Lamu as a distinct travel destination, and a serious political issue in the form of extensive land-grabbing throughout the Lamu archipelago and into the immediate hinterland of the coast, where the planned transit corridor, railway, and oil pipelines linking up northern Kenya to Sudan is projected to run its course. Lamu town is an UNESCO World Heritage Centre, a status it shares with several other living towns and archaeological sites along the Swahili coast. It is a major travel destination for foreign tourists, mainly Europeans, but also enjoys the annual influx of coastal Muslims from Kenya and Tanzania for Maulidi, the religious celebrations commemorating the birth of the Prophet Mohammed. In the 1980s, when Lamu's UNES$\mathrm{CO}$ status was negotiated, the town and its environs had long suffered economic marginalization and decline, and its urban waterfront redevelopment became a major incentive to attract visitors and capital into the town, known among some European travelers since the 1960 s as being the 'Marrakech of East Africa', idealized in its unique architecture and mosques (Hoyle 2001). Even prior to this significant cultural and political redevelopment of the town and prior to the very unevenly shared 'boom' in tourism, the idea of building a modern port facility at Lamu had been discussed in Parliament, the Kenya National Assembly, at least since 1969, when the Government of Kenya seriously contemplated spending money on a feasibility plan as to the potential of the natural harbor at Manda Bay for tankers and container ships. Member of Parliament for Lamu constituency in 1970, Abubakar Madhbuti developed the idea that Lamu's economic torpor was a political project, and one that implicated Kenya's competition with other seaports along the eastern African littoral:

'The only thing we can do is to save Lamu from dying day and night is to establish a second port at Lamu. Every country, Sir, has a first and second port. For example, in Egypt we have Alexandria and Port Said; In Tanzania we have Dar es Salaam, Mtwara and Tanga; in Somalia they have Mogadishu, Berbera and Kismayu. It is only in Kenya where we do not have a second port. Therefore, my suggestion to the Minister for Economic Planning and Development also the Minister for Power 
and Communications, is that Lamu should be developed and made the second port of Kenya. Also, Sir, the port should be made a free port; so that no taxation or custom duties is levied. This is the only way we can attract industries in this area. If we do not develop in this way, we shall find that after nine or ten years to come, people will desert Lamu because there is nothing that can be done to save them there. (Kenya National Assembly Hansard, 10 March 1970).

The problems outlined by this politician, a member of Lamu's patrician classes, were implicated in Lamu's inaccessibility, often only reached by those affording flights landing at the small airstrip on Manda Island, across from the old town. Further, however, was the question of land tenure and 'squatters', an issue that would become highly significant in the development of LAPSETT and the building of the mega-port in 2012. His words of 1970s could be heard as prescient of things to come: "We are still considered squatters of the state ... this is a very peculiar way of colonizing the people ... what is security but land?" (ibid.).

This question of land security is the most controversial element of LAPSETT and the rush to speculate on land around the port and refinery complex, but also along the line of the road pushing inland across the northern region towards South Sudan and Ethiopia, is the source of intense political tensions. In the spotlight are up-country 'land grabbers', speculators targeting the whole region who look for illicit or extra-legal means to displace current land users - often categorized as squatters, even if they, like the Boni (Aweer), are considered indigenous peoples - where profits can be made (see Nunow 2012). The Boni land ranges lie just inland from the coast, a fragile savannah eco-system that has sustained their hunting and foraging, but rendered these peoples, classified as 'minorities' by the 2010 Kenya Constitution, exceptionally vulnerable to the effects of the mega-port and its attendant road network, oil pipe lines, and railway. Despite consultation processes held in Lamu Town, known as 'sensitization' meetings, the views of marginal peoples in the Lamu area, such as the Boni, have been under-played in the Kenya media, their concerns raised almost exclusively by non-governmental organizations and independent scholars (Nunow 2012; Goldsmith 2013: 133), laying bare the vulnerabilities of many peoples being affected by this development, many of whom are pastoralists or foragers living in the arid hinterlands of the north. Abdirizak Arale Nunow (2012), author of a 
scathing report on LAPSETT's impact on the Boni, captures the mood of Lamu's residents:

Within ten years of the development of the massive infrastructure proposed, the mainland will have been converted into what the Kenyan government hopes will be a modern 'growth area' replete with oil refineries, high-speed railways, two international airports and several resort cities. If projects live up to artists' planning, the area will be East Africa's answer to Dubai, though distinguished from the Gulf's boomtown by a high tide of vice, chiefly prostitution and drugs. Residents of Lamu are finding it difficult to fathom that in a short time coral reefs prized for snorkeling and offering habitat to the endangered dugong, a manatee-like aquatic mammal, will be dynamited, the picturesque dhows displaced, and channels dredged to accommodate the daily passage of up to ten Panamax container ships, the world's largest operating commercial vessels (Nunow 2012: 4).

The Lamu Port project and the larger LAPSETT complex fuels controversy owing to its massive scale and purpose: to provide land-locked South Sudan with an affordable infrastructural backbone to export its considerable oil supplies to China. The Chinese investment, facilitated through a Build-Own-Operate-Transfer (BOOT) scheme, came when an initial Kuwaiti tender for the project was rejected after Ethiopia's government wanted to come into the scheme, exemplary in this neo-liberal moment for major political and economic co-operation between Kenya, South Sudan, and Ethiopia with foreign capital. The multipolarity of this gargantuan project intersect in a larger transnational project of reorganizing capitalism in the region.

The newly initiated Lamu Port project is projected to cost US \$15 billion, a sizable amount of which went to the company, Japan Port Consultants, who carried out the whole LAPSETT feasibility study, including analyses of the economic costs of a major transit corridor through northern Kenya. This transit corridor has long been demanded by northern politicians, particularly those intent on seeing the road from Isiolo to Marsabit and onto the Ethiopian-Kenyan border town of Moyale tarmacked and capable of handling the axle-weight of everyday haulage. The road network passes initially on its interior route through Garissa, a small town within proximity to the huge refugee camps of Dabaab, housing increasing numbers of Somali fleeing the recent trans-border war in the Horn, before bifurcating at Isiolo, where one of three 'tourist resort cities' is planned to be built. At the junction of Isiolo, an important regional town, two further roads are 
to be built, one leading to South Sudan, Africa's most recently independent nation-state, and the other leading to Ethiopia. For anyone who has traveled on the rough, dusty, corrugated, and dangerous roads of the north, the idea of driving along a tarmac road has been a dream first argued for in the years following Kenya's independence (Uhuru) in 1963 and the 'Shifta Emergency', Kenyas second civil war, that immediately followed it.

Northern Kenya stands to be radically transformed by the long-awaited building of a tarmac road network, but the region has experienced insecurity and profound ambivalence towards models of development that generate further marginalization among its inhabitants. While these developments are linked to a long-lived desire to turn Kenya into a model of capitalist success in Africa, something ordinary citizens are often uncritically proud of, those concerned politically about the inequities being reproduced through infrastructural 'maximization' might pause to reflect on an emergent polity organized by the management of mobility and its primary political sign: speed. Based on several years of fieldwork in mobile and multiple sites throughout the country, during a period when infrastructure was one of primary political issues, seconded only to land reforms and civic freedoms, the transformations to the transport industries, road works, port facilities, ICT and mobile technologies, engineering firms, international financiers, insurance industries, and diplomatic relations are remarkable, not only in terms of their scale, but more importantly by the social effects they have had along the line of the road. It can be suggested that the advent of neo-liberalism in Kenya brings an array of contradictions into play, one outstanding one being the redefinition of what it means to be a citizen of Kenya today. Resident anthropologist, Paul Goldsmith (2013: 133), has characterized this contradiction by borrowing from the Kenyan designations, Kenya 'A' and Kenya 'B': the first one being Nairobi and towns along the road networks; the second mainly referring to the northern regions of the country bordering Somalia and Ethiopia to the north, northern Uganda and South Sudan in the northwest and, to some degree, the Maasai enclaves along the Kenya-Tanzania border. This ambiguous sentiment of being 'second-class citizens' was frequently raised in the National Assembly by northern Members of Parliament, a debate about how Kenya's 'infrastructural backbone', firstly along the central railway, then through the dense network of roads through the agriculturally pro- 
ductive highlands and western towns and cities in the environ of Lake Victoria. Kenya 'B' had long desired a well-maintained international road to pass through their landscape, shaped more by transhumance than the automobile, but felt that they had been fed empty promises.

This question, of course, depends on how people are situated visà-vis roads and the provision of goods, the delivery of medical or educational services, or even legal and physical protection. Banditry remains a problem along the line of the road, in both urban sprawls and sparsely populated hinterlands. But most of the sources of marginalization in Kenya today have to do with property relations, as with the case of large numbers of Internally Displaced Persons (IDPs), or else, northern pastoral communities whose loss of herds following years of drought and generalized insecurity have quite literally pauperized the small settlements built at the road-side. Large northern populations, such as the Boni, living near the coastal port of Lamu, may experience the building of the LAPSETT Corridor, as an example, as a double dereliction on the part of government interests: firstly, by building the initial older road through Witu to Lamu, often impassable during the rains; then, by building one of the most ambitious transport corridors through a region wracked by conflicts, mainly over land. Urban citizens, for their part, may experience greater danger from pollution or death and injury under the wheels of an automobile simply accorded by where they call home within the cityscape. Novel social hierarchies also emerge in dialectic within this social-infrastructural nexus: the wealthy can fly Kenya Air for an 'affordable fare' on brief business trips; the poor must travel in mini-vans and buses at extortionate prices, often overcrowded, in various states of discomfort and danger. Yet many within Kenya are arguing that despite "Vision 2030"'s three 'pillars', embodying a holistic model of development, the underlying inequities of Kenya's half-century of post-coloniality are being reconfigured within a volatile regional and international scene. The promises of multipolarity, as indicated in the introduction of this chapter, may take some further time before their consequences can be understood properly and within the necessary local contexts through which LAPSETT's roads and oil pipelines will pass. 


\section{Conclusion}

In an earlier moment of anthropological fascination with globalization and 'millennial' capitalism, Allen Sekula described south China as a "primary industrial hinterland for the port of Los Angeles" (Sekula 1999: 146). He added, ironically, that the containers leaving Los Angeles Port exported mostly air, hinting at the deep crises characteristic of America's declining hegemony over 'late' capitalism. China has figured prominently in many discussions about the future of globalization, spawning discussions that are sometimes alarmist, frequently nationalist, but mostly fearful. It is into this sensationalist kind of discourse that anthropologists would wish to enter, to engage in some kind of dialogue with other critics of globalization, towards understanding in clearer focus what matters most in our cosmopolitan, planetary future. And, as such, ethnographers have traveled the world looking for the 'right' place to grasp globalization - in a stunning array of sites from Beijing's financial trading floors to the burning forests of the Meratus Mountains on Kalimantan, Indonesia - a quest for socially perceivable traces of globalization that are lived at length from the abstractions to which the 'global' is afforded. Wherever we locate 'the global through the local', we're also guilty of paying more attention to particulars than to the largest possible connections between these two points of a horizontal scale, as when one stands at the ocean's edge and looks out towards the horizon. Alongside customs posts and borders, ports are also visited by ethnographers looking for globalization, and capturing something of the 'big picture' as it is reflected in the lives of ordinary people (Chalfin 2006; Nordstrom 2007). Since this scholarship on the place of ports and oceanic transport corridors in regulating the accelerated pace of globalization, China's geopolitical and economic presence in the world has gathered not only superlative productive force in shaping 'late' capitalism, but also far-reaching ideological momentum, especially in that zone of the world's economy that was figuratively seen in the 'shadows' of globalization: namely, Africa (Ferguson 2006). What tends to get overlooked, however, are the relationships between members of different countries in this multipolar conjuncture, a point iterated by Goldsmith in reference to LAPSETT: "The potentially negative impact of Asian capital in marginal regions is aggravated by reform-dampening political patronage at the centre" (Goldsmith 2013: 133). 
This chapter's main case study is not set in the Pacific Ocean, but in the western Indian Ocean's port town of Lamu, on the northern Kenya coast close to Somalia, where - against the wildest imaginations of its residents only a decade ago - the Kenyan government intends to build, in partnership with mainly Chinese firms and investment, an ultra-modern port facility capable of berthing Super Panamax vessels and the refineries to process oil piped in from land-locked South Sudan, Africa's newest nation-state (see Nunow 2012). Unlike many earlier mass-scale infrastructural projects, like the building of the oddly named Northern Corridor, roughly following the colonial railway lines, the Lamu Port Project is financed by investment in the region from seemingly novel geographic sources, that is to say, companies registered in India, Qatar, or China, rather than Israel, Germany, and America. Not content with the stability of James Ferguson's (2006) motif of 'global shadows', this chapter theoretically draws on anthropological notions of 'friction' in the ethnography of globalization (Tsing 2006) and develops a complementary perspective on the acceleration of Kenya's infrastructural development through speed's implication for political transformation.

Apart from these theoretical contributions, the chapter is most intent on forwarding the idea that the recent concerns with 'multipolarity' in Africa's political economy - the theme of this volume would do well to be more explicitly historicized in any treatment of 'traditional' or 'non-traditional' sources of investment, taking care to evaluate rhetoric overburdened ideologically by the compelling spin of neo-liberalism's apologists. In order to do this, I discuss the historical multipolarity of Lamu since at least the 15th century and the intertwining of African and Chinese approaches to building infrastructure and the growing 'desire' for mobility through improved transport and communications by citizens over the course of Mwai Kibaki's presidency (2003-2013). At a third level, I am also interested in partially dissolving the implicit 'methodological nationalism' within this analysis through reference to a larger political-economic context of East Africa, inclusive in this case beyond the East African Community as a political organization towards the eastern African region as a whole (to include South Sudan, Ethiopia, Somalia, Uganda, Tanzania, Rwanda, Burundi, and eastern Congo). Across these scales - from localized changes in the landscape to the hidden politics of global investment - people find themselves engaged in many, 
complex kinds of negotiations with the state's infrastructural power. A concept borrowed from Michael Mann's (1986) theorization of the sources of social power, 'infrastructural power', becomes one way of understanding the social and political effects of state regulatory powers, whether this refers to deals struck behind closed doors in Beijing or the personalization of this power through police-driver collusion at roadblocks along the planned, new highways. We must work to have a theory of how neo-liberalism is reproduced through the infrastructural power of the nation-state, as much as it is through the invisible traces of foreign investment.

I speak of Africa's 'new infrastructural dispensation', or even, an African 'infrastructural renaissance' to capture some of the excited rhetoric surrounding these developments, not only in their grand-designs, but also in some of the envisioned conflicts and opportunism that these massive development projects throw open, including political protest and armed violence. In Kenya, the Lamu Port South Sudan Ethiopia Transport Corridor (LAPSSET) project is one such proposed, ongoing development initiatives dreamt up and designed by many disparate non-local actors and agencies. Starting at the Indian Ocean port of Lamu - modernized - this project aims to build major transport links throughout northern Kenya, constructing international highways and railways to South Sudan and Ethiopia. LAPSSET is a particularly hot topic of conversation among many Kenyans owing to the controversy surrounding government tendering and consultation processes. Part of Mwai Kibaki's "Vision 2030, its proponents plan the country's second major transport corridor (rail and automotive), oil pipelines and refineries, service hubs and tourist resorts, international airports, fiber-optic communications. A truly complex picture of who's who emerges from the many 'stakeholders' in the official project, no less than those who, for various reasons, oppose it for its projected harm. Looked at historically, moreover, it becomes clearer that the denizens of the UNESCO World Heritage Centre of Lamu - the epicenter of the controversy - live within the Indian Ocean nexus and, as such, have had encounters, often to their disadvantage, with world 'cosmopolitanism' (in its Kantian sense) since the 15th century C.E.. Drawing up a list of the mariners, traders, and overlords to reach and stay in Lamu proves something of this port's multipolarity over the longue durée. While I briefly attended to the politics of the Lamu Port project above, especially 'land grabbing' and damage to local environ- 
mental and cultural heritage, LAPSSET has generated further conflicts inland along the course of the Tana River, reaching deep into the arid hinterland of the country's north.

In Kenya's fifth decade of independence from Britain, a composite strategy of 'economic growth' is taking form through investment in infrastructural expansion of the transport and communications sectors. If a visitor were to visit Kenya for the first time in 1991, as is my case, and not return until the present day, they would undoubtedly be struck by the eight lane super-highway from Nairobi to Thika; the construction of Kenya's 'Silicon Savannah', Konza City, a planned informational-communications industrial city; massive rural road paving projects and the extension of mobile communications mast networks into previously 'off-grid' areas; the renovation of the Northern Corridor, engineered to take on faster, safer, larger traffic loads onto Uganda and the Great Lakes region. It is not only the road building and expansion of road-side services that is noticeable, but also the ways in which these development projects evoke new discussions and debates about Kenyas future. In the north, however, "Vision 2030" comes across rather more suspiciously after nearly a century of political, economic, and infrastructural 'neglect' on the part, firstly, by the British colonial government, then the postcolonial state.

The vast northern arid lands of Kenya, once called the 'Northern Frontier District' by colonials, are historically peopled by pastoralists, whose transhumance in search of water for their animals - their 'traditional' economy - has been severely disrupted through limited markets, huge transaction costs, cattle raiding and other forms of conflict and insecurity. Transport in this northern region is expensive, arduous, and dangerous, making the price of basic commodities beyond the means of large numbers of pauperized and sedentarized pastoralists, most of whom have settled in big towns, missions, or service stations along the line of the existing road. Since Independence in 1963, northern politicians have historically decried the 'neglect' of all governments, including the British, who many argue 'rigged' the Successionist Referendum following independence to disallow Kenyan Somalis from joining the newly formed Somalia. The result was Kenya's first postcolonial civil war: the so-called Shifta Emergency. In times of relative peace, Members of Parliament elected from among northern communities, further pushed the issue of neglect with respect to development in education and health, but underscored the 
central importance of building infrastructure, namely, a safe and well-maintained tarmac road. On the last time I traveled from Isiolo to Marsabit in 2003, the road reaching north to Moyale and the escarpments of Ethiopia was rough and heavily corrugated, not to mention dangerous owing to the ever-present threat of banditry, or, more common but less alarming, the almost non-existence of medical services along the road to respond to the road's frequent accidents. It is through this landscape and these communities that LAPSSET's motorway will pass through on its way to Ethiopia and South Sudan. From its start through to its completion, LAPSSET will fall under a greatly expanded military 'securitization' over the region's marginal pastoralist populations, groups of people that have historically found themselves to be in conflict with the state, whether colonial or postcolonial. Controversies rage over the future of LAPSSET and it is the task of this chapter to interpret their dynamics within the larger context of East Africa's infrastructural politics.

\section{References}

Brautigam, Deborah. 2009. The Dragon's Gift: The Real Story of China in Africa. Oxford: Oxford University Press.

Chalfin, Brenda. 2006. Neoliberal Frontiers: An Ethnography of Sovereignty in West Africa. Chicago IL and London: University of Chicago Press.

Goldsmith, Paul. 2011. "How Grandiose Lamu Port Project is Alienating Coastal Communities from Kenya”. The East African, September 18. HYPERLINK http:// www.theeastafrican.co.ke/business/Lamu+port+project+is+alienating+coastal+communities+from+Kenya+/-/2560/1238454/-/sutx91/-/index.html

Ferguson, James. 2006. Global Shadows: Africa in the Neoliberal World Order. Durham NC and London: Duke University Press.

Harvey, David. 2005. A Brief History of Neoliberalism. Oxford: Oxford University Press.

Hoyle, Brian. 2001. "Lamu: Waterfront Revitalization in an East African Port-City". Cities, 18 (5): 297-313.

Republic of Kenya. 1970. Kenya National Assembly Hansard, March 10, Pp. 571.

Lamont, Mark. 2010. "An Epidemic on Wheels? Road Safety, Public Health and Injury Politics in Africa". Anthropology Today, 26 (5): 3-7.

Lamont, Mark. 2012. "Accidents Have No Cure! Road Death as Industrial Catastrophe in Eastern Africa”. African Studies, 71 (2): 174-194.

Lamont, Mark. 2013. "Speed Governors: Road Safety and Infrastructural Overload in Postcolonial Kenya”, Africa, 83 (2) pp.?

Larkin, Brian. 2008. Signal and Noise: Media, Infrastructure, and Urban Culture in Nigeria. Durham NC and London: Duke University Press. 
Loimeier, Roman and Rüdiger Seesemann. 2006. The Global Worlds of the Swahili: Interfaces of Islam, Identity and Space in 19th and 10th Century East Africa. Hamburg, Berlin: LIT-Verlag.

Mann, Michael. 1986. The Sources of Social Power: A History of Power from the Beginning to A.D. 1760 (Vol. 1). Cambridge: Cambridge University Press.

Morris, Rosalind. 2010. "Accidental Histories, Post-Historical Practice? Re-reading Body of Power, Spirit of Resistance in the Actuarial Age". Anthropological Quarterly, 83 (3): 581-624.

Ngarambe, Alex. 2013. "We Are Discriminated Against at Port of Mombasa: Traders". The East African, January 25, HYPERLINK "http://www.theeastafrican. co.ke/Rwanda/Business/We-" http://www.theeastafrican.co.ke/Rwanda/Business/ We-are-discriminated-against-at-Port-of-Mombasa/-/1433224/1675130/-/duqxt$\mathrm{mz} /$-/index.html

Nordstrom, Carolyn. 2007. Global Outlaws: Crime, Money, and Power in the Contemporary World. Berkeley: University of California Press.

Nunow, Abdirizak Arale. 2012. The Displacement and Dispossession of the Aweer (Boni) Community: The Kenya Government Dilemma on the New Port of Lamu. Land Deals Politics Initiative (LDPI): Ithaca, NY: Cornell University

Pederson, Poul O. 2001. "Freight Transport Under Globalisation and Its Impact on Africa". Journal of Transport Geography, 9: 85-99.

Sanya, Samuel. 2013. "Kenya to Hike Port Fees". New Vision, March 20 HYPERLINK "http://www.newvision.co.ug/news/635960-kenya-to-hike-port-fees.html" http:// www.newvision.co.ug/news/635960-kenya-to-hike-port-fees.html

Sekula, Allen. 2001. "Freeway to China (Version 2, for Liverpool)". In: J. Comaroff and J. Comaroff, eds. Millennial Capitalism and the Culture of Neoliberalism. Durham and London: Duke University Press.

Teravanithorn, Supee and Gaël Raballand. 2009. Transport Prices and Costs in Africa: A Review of the Main International Corridors. Washington DC: The World Bank.

Tsing, Anna. 2006. Friction: An Ethnography of Global Connection. Princeton NJ and Oxford: Princeton University Press. 
THE COMPULSION TO DO THE RIGHT THING: DEVELOPMENT KNOWLEDGE AND ITS LIMITS

\section{Elísio Macamo}

\section{Introduction}

Recently the World Bank launched a new initiative to ensure the effectiveness of its aid to so-called developing countries by strengthening the ability of civil society to demand accountability from governments. It is called "Global Partnership for Social Accountability" (World Bank 2012, see also 2005; McNeil and Malena 2010). The initiative assumes that the accountability of governments before their own society is crucial to the success of policies. ${ }^{1}$ In the same breath it further assumes that most developing countries lack accountability. An interesting aspect of this initiative is that it involves several international organizations ranging from development agencies to academic institutions, all of which have committed themselves to investing financial and intellectual resources to helping developing countries overcome this particular deficit. The current financial commitment of the World Bank is around US $\$ 20$ million, but over the next seven years the project is expected to benefit hit US $\$ 75-125$ million. The stakes are high and it is clear that the World Bank and its partners mean business.

But what kind of business do they mean, and most of all, what does it tell us about the state of aid policy in these days and, in particular, the kind of knowledge on which it is based? On the face of it, it would seem that the international aid apparatus seems to have identified one of the most important weak spots of the operational aspects of the aid architecture. It may have been many years since, but Amartya Sen's seminal work (1992) on the correlation between democracy and development outcomes, and especially, the emphasis which he placed on the importance of accountability as engineered by freedom of expression, seems to be receiving further acknowledgement from the World Bank. On second thoughts, however, there may be some reason for caution in

${ }^{1}$ This has in fact become the standard credo of political commentary on the failure of development (see in this respect Jha et al. 2011; Arien 2010) 
drawing such a conclusion. The Global Partnership for Social Accountability will pour money into civil society organizations which design and implement programs that help communities in developing countries to hold their governments accountable. Some of these programs entail the critical evaluation of service delivery in those areas which are of more immediate concern to broader sections of the population of developing countries, namely health and education. What is remarkable about such a form of intervention, however, is the extent to which in acknowledging the failure of polities it seems to assume that interventions of a technical nature may be an adequate substitute for the messy, slow and often dirty and inefficient practices of normal politics. To put it differently, the initiative appears to document one particular problem of the kind of knowledge which is produced in development policy. Development knowledge assumes for every problem there is a technical solution. Indeed, the assumption is even far more reaching. The integrity and plausibility of development knowledge rests on the belief that it has a vocation which consists in translating problems of a political nature into technical problems requiring technical solutions.

The purpose of this paper is to discuss these assumptions. The paper will focus on the nature of development knowledge to argue that it is based on epistemological assumptions that render it unable to contribute towards a real understanding of the changes that are currently taking place within the African continent as well as to assess the challenges and opportunities which arise for Africa in view of the increasing multipolarity of the world today. Africa's current economic boom (see for example Miguel 2009) as well as the emergence of new donors such as China and Brazil (Taylor 2006; Brautigam 2009; Cheru and Obi 2010) pose real challenges to received wisdom in development policy and practice while at the same time demanding a reassessment of its underlying assumptions. I will claim that the problem with development knowledge is its teleological nature. It uncritically assumes that "development" is not only the goal, but also the fate of every country in the world. In other words, development knowledge has proclaimed development as a norm in the evaluation of historical change around which it seeks to render the world intelligible. To be sure, the assumptions underlying development knowledge have generated, and given substance to, much intellectual debate since the institutionalization of aid a few years after the Second World War. I contend, however, that these debates fell short of a critical engagement with the epistemological shortcomings under- 
girding development knowledge for reasons which probably had to do with the highly politicized nature of the debate that dominated development studies from the early years up until perhaps the mid of the nineties. While the debates brought attention to bear on real structural inequalities - the contribution of world-systems theory in this regard is worthy of note - they did not put enough focus on the kinds of issues which would have led us to pay more attention to the assumptions underlying development knowledge. As a consequence, we are faced with a situation in which the kind of knowledge that we have about development may not help us make sense of the changes that are taking place in Africa and in the world. An important implication that I wish to draw from this discussion ties in with the World Bank's preoccupation with social accountability and concerns, in effect, the role which politics here understood as the situated manner in which societies engage in debate over the nature of the moral obligations which bind them and how best to discharge them - may play in bringing about outcomes that can be articulated with development in one way or another. Because of the nature of development knowledge, which will be discussed in more detail further below, thinking about politics in Africa tends to be highly normative in content and orientation. Instead of developing conceptual frameworks which engage seriously with political action as it emerges and consolidates itself in everyday life, more attention is paid to testing the usefulness of normative concepts that are more apt to find fault with what is happening in Africa. Such concepts as neopatrimonialism (see for example van der Walle 2001) are evoked not so much to describe the nature of politics in Africa as to draw inspiration for an account of why Africa is not making it. ${ }^{2}$ The general point I want to make in this connection is that the epistemological assumptions which inform development knowledge have tended to lead to a rejection of politics. This explains initiatives such as those by the World Bank to empower civil society to demand social accountability. On a deeper level, development knowledge amounts, for reasons that I will discuss in more detail further below, to a denial of history. ${ }^{3}$

${ }^{2}$ Chris Allen (1995) offers a balanced and timely critique of these problematic approaches to politics in Africa.

${ }^{3}$ The position defended in this paper differs from that of de Rivero (2010) who simply rejects the idea that development for late-comers may be possible. My claim is that we should wary of knowledge that does not contemplate the possibility that things may be otherwise, namely that development may not be the only option available to countries. 
The economic rise of China and Brazil has been taking place against the background of a shift in the traditional aid architecture away from technical aid to projects broadly defined as likely to further the goals of development to a growing emphasis on policy reform as an important and necessary precondition of development success In fact, such fears helped shape the philosophy behind the new aid architecture that is so fundamental to the DAC consensus (Mosse and Lewis 2005). The new architecture emphasizes policy reform as opposed to aid transfers within the general framework of market liberalism. While there is much to criticize in this shift (see Ferguson 2006; Gould 2005), there is also much to commend, especially in terms of the emphasis that it places on ownership as opposed to conditionality (for a critique of conditionality see Collier 1997). The new aid architecture would seem to suggest that all that is needed to secure positive outcomes in development are good institutions based on the principles of good governance. There is a broad ranging literature that does indeed make this assumption and manages to make a convincing case for such a perspective. The problem with this assumption, however, is that it is very difficult to translate into practical action. Good governance programs have been put into place for many years, but it is not clear how successful they have been. Indeed, since the much hailed Paris Declaration of 2005, which extolled the virtues of "ownership" (see Whitfield 2009 for a thoughtful critique), saw the light of day the trend amongst traditional donors has been towards encouraging countries to adopt policies thought to have the potential to improve development prospects. As some authors have pointed out (see for example Browne 2006; Abbas and Niyiragira 2009; Murphy 2005; Lancaster 2007), the main gist of the reforms fostered by the new development discourse has been to enforce a neo-liberal agenda on developing countries, thus sealing a fate which had already been heralded by the adoption of structural adjustment policies in the 1980s (Mkandawire and Olukoshi 2005; Mkandawire and Soludo 2003; Nelson 1990).

To be sure, the earlier shift towards "good governance" had already indicated the shape of things to come as responsibility for the success and failure of development efforts came increasingly to rest on recipient countries' commitment to reforms along neo-liberal lines and their willingness to pay more than just lip service to them. Perceptive observers (see, for example, Abrahamsen 2001) had already pointed out the elective affinity of "good governance" discourse and neo-liberal reforms. Abrahamsen went even so far as to see in so-called democ- 
ratization processes disciplinary measures to render countries intelligible and accessible to neo-liberal intervention. One could use James Scott's terminology here to suggest that the new reform agenda was geared towards making developing countries legible (Scott 1998), a point which I also made in an earlier analysis of Mozambique's Structural Adjustment Program (SAP, see Macamo 2006a).

China's and Brazil's respective rise, which though different in terms of the political background underlying each one of them, owe little to the normative narrative of development policy and practice, i.e. liberal democracy, large-scale opening of markets, expansion of service and financial sectors, etc. cast doubts over the merits of the policy recommendations that are being made to developing countries within the framework of the new aid architecture. $4^{4}$ The unquestioned economic success of China and Brazil seems to show at the very least that there may be alternatives to development which do not necessarily require the types of policy mix that the received wisdom of development practice and policy has been preaching to recipient countries through SAPs and "good governance" policies. Furthermore, the manner in which these two countries, i.e. Brazil and China, along with other socalled BRICS countries (i.e. Brazil, Russia, China, India, and South Africa) seem to have stimulated processes of growth in Africa would appear to raise interesting issues over not only the policy recommendations that are still being foisted upon African countries, but also the whole thinking upon which development policy and aid appear to be based. In fact, more than casting doubts on whether particular instances of neo-liberal thought, such as market economics and accountable polities, can really deliver on their promise current developments on the African economic front may point to major weaknesses in the epistemological grounding of development thinking.

These are the issues that will be considered in this paper. In order to do so I will start with a discussion of "development knowledge". The aim is to argue that development policy and practice have given birth to a very specific form of knowledge, the epistemological assumptions of which have seldom been critically assessed. I will draw from two internationally little known and discussed German-language texts written in the 1980s and which engaged these assumptions in particularly insightful ways. The purpose of calling on the authority of those texts

\footnotetext{
${ }^{4}$ For a trenchant critique of the normative narrative underlying neo-liberal politics see Chang $(2002,2010)$.
} 
will be to point to the weaknesses of development knowledge and, in that way, begin to explore the particular challenges which current developments in Africa pose to academic research on development, whatever is meant by such a notion. This discussion of development knowledge should prepare the ground for a reflection on the relationship between knowledge and praxis in development policy and practice. Such a reflection will seek mainly to draw attention to the role of politics in Africa's development.

\section{Development knowledge and its weaknesses}

Past discussions and debates over the usefulness, or uselessness of development aid, tended to be informed by ideological concerns. These left little room for a consideration of epistemological issues concerning the quality of the knowledge to be gained about development processes. The critical gaze hailing from the dependency school, for instance, (see, for example, Amin 1990), may with the benefit of hindsight be seen as having been timely in reigning in the excesses of modernization theories and their extremely upbeat tones over the development prospects of countries emerging from colonial rule. However, in holding on to the idea of development, albeit outside of the capitalist logic criticized by world systems theory, the critique of the dependency school left an important premise of development policy and practice unquestioned, namely the firm belief in the fundamental attainability of development. Post-structuralist critiques such as those which came to be voiced by Arturo Escobar (1995) and, to a lesser degree, by the early Ferguson (1990) moved some way towards the beginning of a serious questioning of these epistemological foundations. While the former drew attention to the extent to which development policy itself produced developing countries as an artefact of its own intervention, Ferguson showed how policies aiming at "development" could actually undermine their own goals by trivializing local politics. ${ }^{5}$

The important points raised by Escobar and Ferguson, among others, failed to have a significant impact on development policy thinking because they came at a time when consensus had started to emerge over Africa's own responsibility in its failure. Starting with Robert Bates' critique of the role of the African state in undermining develop-

${ }^{5}$ Richard Rottenburg's (2009) almost fictional representation of the travails of a development consultant in a fictional African country also takes up similar issues, albeit focusing on how reality becomes an artefact of organizational structures. 
ment (Bates 1981) and the endorsement of this critique by the World Bank attention came increasingly to bear on these issues (see for example Bayart 1993; Bayart et al. 1999; Bratton 1989; Bratton and van der Walle 1994; van der Walle 2001, etc.). ${ }^{6}$ As more and more attention was paid to the relative merits and demerits of the African state, less attention was devoted to questioning the epistemological assumptions underlying development thinking. ${ }^{7}$ Precisely these assumptions need to be brought under scrutiny, for they play a central role in our ability to adequately assess Africa's potential and challenges.

Interestingly enough, two texts published in German around this time dealt directly with these issues, but their impact - even within the context of German-speaking development studies - was negligible. The first text was written by Friedrich Tenbruck ${ }^{8}$ (1987) and published in two languages, namely German and Italian. Tenbruck's text was mainly concerned with questioning the notion of "development" in its relation to how well it described the contemporary status of the world. In doing so, he also raised questions concerning the relevance of development sociology as the discipline that carried, within sociology, the burden of identifying developmental processes in order to give policy makers solid evidence for their decisions. Tenbruck's critique drew in the main from the tendency of development studies to reduce the world to its developmental properties and, in this way, to see development as the general key to the solution of all problems faced by countries. Not unlike Arturo Escobar, but mainly echoing Georg Simmel's seminal work on the poor, Tenbruck argued that developing countries were not developing countries because of their economic, social and political characteristics, i.e. poor economic performance, poverty, rampant disease and political instability, among others. Rather, they became developing countries because of the programs which were brought into life to eliminate those characteristics.

\footnotetext{
${ }^{6}$ One should not forget Robert Jackson's and Carl Rosberg's (1982) description of African states as "quasi-states" and the devastating effects which the label had on the study of African politics. See also Jackson (1990)

${ }^{7}$ See Pitcher et al 2009 and Erdmann and Engel 2006 for a discussion of these issues.

${ }^{8}$ Friedrich Tenbruck, a German cultural sociologist who died in 1994 aged 75, was one of the most important interpreters of Max Weber's sociology. He is largely credited with having emphasised the cultural nature of Weber's sociology. Like many mainstream German sociologists, Tenbruck did not have any particular interest in non-European affairs. This may explain why little attention was paid to his thoughts on development sociology, as either his immediate German colleagues were not interested in the issue or those most concerned with development issues were not interested in Tenbruck.
} 
In other words, the definition of the situation of the world in terms of a universal evolution from a condition of primitiveness towards development had imposed itself as a norm to guide action while at the same transforming all countries in the world displaying features consistent with the absence of development as a problem to be addressed by concerted action by the international community. The problem with this vision, according to Tenbruck, is that development can hardly be reduced to the concepts that constitute it. Development also implies human, social and historical conditions that may even stand in contradiction to the normative content of the concepts of development. In this sense, then, it could even be argued, as Tenbruck in fact did, that a concern with development issues may come to be an obstacle in our ability to perceive reality, in particular the reality that emerges out of human reaction to developmental interventions.

To be sure, aspects of Tenbruck's reasoning have been echoed to different degrees by different authors. James Scott's "Seeing like a state" (1995) while not claiming to be a critique of development policy per se can, indeed, be read as such. This is particularly the case as far as the emphasis which it places on critiquing the logic underlying what Scott describes as "schemes to improve human wellbeing" is concerned. There are elements of Karl Popper's earlier critique of historicism (Popper 1989, 2011) and, especially, the dangers of totalitarianism that historicism implied. The same fears form, in fact, the basis of William Easterley's massive indictment of development policy (Easterley 2006). They also provide the rationale for his suggestion that development efforts follow the logic of the "seeker" rather than that of the "planner". "Piecemeal social engineering" is Easterley's counter-suggestion borrowed from Karl Popper. It echoes James Scott's suggestion of what he calls a "métis"9 logic to counter the pernicious effects of the totalitarian logic of schemes to improve human wellbeing. While not directly drawing from Tenbruck, the work of Scott and Easterley echoes the former in significant ways by drawing attention to the epistemological grounding of development knowledge. On this account, development knowledge is undermined by its own normativity and failure to entertain the possibility that the world could be moving in directions which do not fit easily into the upbeat narrative of uni-linear progress. These authors emphasize the idea

\footnotetext{
${ }^{9}$ Scott uses this notion to refer to tacit and practical everyday knowledge that is based on taking small steps, learning from mistakes, correcting them and moving on.
} 
that a reduction the purpose of human life a few basic elements that are descriptions of what needs to be done to achieve the end of history runs the risk of limiting our ability to appreciate diversity, complexity and the fundamentally open-ended nature of the course of humanity.

Another German speaking author who has made a significant contribution to thinking over the epistemological foundations of development knowledge is Stefan A. Musto ${ }^{10}$ (1987). This author put forward the view that development policy is based on an asymmetric relationship between the institutions of development policy and recipient countries. While the former formulate questions, the latter are expected to accept those questions as legitimate descriptions of their own condition. His point of departure is not unlike Tenbruck's in that he argues that development policy is the historical pattern of the structures and forms taken by development institutions. This pattern manifests itself, according to Musto (1987: 429) in two types of logic. The first one is institutional and refers to the reproductive need of institutions which exist to address a problem. Institutions reproduce themselves by defining problems in ways that make them necessary. Most importantly though as far as Musto is concerned the institutional logic of development policy can easily turn into a manipulative logic when it goes beyond its own mandate to secure the minimal conditions of its own reproduction to actually attempting, whether requested or unrequested, to make others happy, sometimes even against their own will. As he puts it:

The manipulative logic is one that forces upon others questions for which it already knows the answers. Manipulation is intervention and in this sense it is the opposite of letting things happen: it is the obligation for things to happen. It is pedagogy in a negative sense; it is the claim to knowing better; it is the authority to praise and punish; it is the presumption of being able to think and act on behalf of others (Musto 1987: 429-30; translation by EM).

Interestingly enough, Musto claims that this manipulative logic is neither the result of an international conspiracy against developing countries, nor the guiding idea behind a new crusade on behalf of universal happiness. The logic is the mere outcome of the existence of institutions that address the problems of development, however these are defined. Manipulation, as it were, goes hand in hand with the ex-

${ }^{10}$ Stefan A. Musto is a German sociologist with a background in philosophy. His book received wide attention in development sociology circles, but did not have a long-lasting impact on development policy and knowledge. 
istence of institutions. There are, to be sure, worlds separating Musto's perceptive critique of development institutions from the kinds of critique that some African voices have been mounting as of late against development policy. Dambisa Moyo ${ }^{11}$ (2008) is one such voice. Her critique is informed, perhaps, by a strong belief in the ability of markets to yield development outcomes as opposed to the institutions of development policy. These, in her view, have only cemented Africa's dependence with the connivance of African political elites while failing to deliver on their economic promises. There is no clear genealogical line that links authors such as Moyo to Musto, except for their misgivings concerning the extent to which African countries have been called upon by development policy institutions to address problems defined by the latter under the expectation that the former adopt the solutions spelt out by the latter.

Friedrich Tenbruck's and Stefan Musto's perceptive arguments lay the ground for a stronger engagement with the epistemological issues attendant on development knowledge. Their critique draws attention to two key issues in the quality of development knowledge, both of which are of relevance to any attempt at critically engaging Africa's development prospects in a multipolar world. The first issue, one which is particularly emphasized by Friedrich Tenbruck, concerns the view of history underlying development knowledge. It is a view described in the past by Karl Popper (1989) as historicist. It consists in the key idea that the kind of world which development policy should help make possible provides us with a privileged point from which we can plot the course each country needs to take in order to reach the end point of history. Marie-Laure Susini, a French psychoanalyst, has once drawn attention to how pernicious such an idea can be. In her irreverent praise of corruption Susini (2008) accuses historicism of denying history by reducing the purpose of history to the fulfillment of a pre-determined goal. There is one aspect of development policy which illustrates this point.

This aspect concerns the role accorded to politics in the formulation of development policy and the use of aid money. Individual donor countries have each their own development policies. Prior to their approval as laws by parliaments these development policies are the object of debate within society. Different groups attempt to assert their

\footnotetext{
${ }^{11}$ Along with the Ugandan activist Andrew Mwenda and the Kenyan journalist James Shikwati.
} 
own views concerning what the aims of a country's development policy should be and how best they can be achieved. More often than not, development policy packages are the outcome of political negotiation, compromise and, generally speaking, horse-trading. No development policy package reflects what is necessary to make development possible, not even if we only consider the modest aims of individual countries. Such packages always reflect the political consensus achieved within a given polity. In this sense, whatever claim they may lay to addressing development challenges must be hedged by this important factor. Curiously enough, donor countries, which are perfectly aware of the political circumstances surrounding their development policy packages, will often forget them and make two problematic assumptions the moment their development policy is translated into practical action abroad.

The first assumption consists in the belief that the outcome of political horse-trading can be seen as an adequate technical response to problems of a technical nature in developing societies. The second assumption is even worse and consists in the expectation that developing countries treat the recommendations coming their way from donors as technical artifacts that should not be tainted by local political horse-trading. In other words, it may be perfectly legitimate for a donor country to fix the aid budget as part of broader negotiations with political adversaries and allies in the donor country itself - which may even go to the extent of offering ministerial positions as a way of securing important coalitions - but utterly illegitimate for recipient countries to use the aid budget as part of their own internal political bargaining. Donors of course have a right not only to wish to know what happens to the money which they give, but also to want to be able to tell governments how to spend the money. The problem with this, of course, is that it is too naïve by failing to realize that developing countries are just as vibrant as societies as donor societies are and, in this sense, will always tend to decide upon the use of aid in ways which are sensitive to local politics. The moral language of development, which is somewhat reminiscent of what Mary Douglas described as "blame" (Douglas 2008) has a broad vocabulary that ranges from corruption, mismanagement, nepotism to neopatrimonialism, etc. in order to describe this particular problem. In fact, there is a sense in which blaming along these lines reflects the unwillingness of 
donors to acknowledge the extent to which recipient countries are just as much shaped by politics as donors themselves are.

The vantage point which development practitioners think that history confers upon them may, on closer inspection, be a mere illusion. It is most probably the illusion that the development process can be steered through the control of all, or most of the factors, that are relevant to the achievement of the expected outcomes. Indeed, there is a sense in which the history of development policy has been the history of the attempt to bring more and more of these factors under the control of the development industry. While every development initiative, for example, structural adjustment, good governance, democratization and now social accountability has its own ecology, all of them can be seen as part of a desperate attempt undertaken by individuals and agencies to control historical processes that by definition lie beyond their control. This would explain why donors can commit themselves to "ownership" as they did in the 2005 Paris Declaration and fail, in practice, to uphold the policies that will actually ensure that developing countries own their development processes. ${ }^{12}$

This leads us into the second issue attendant upon the epistemological implications of development knowledge. As a matter of fact, the view that there is no vantage point from which to appreciate the course of history amounts to the realization that history, deep down, is an open-ended process. The question however is what the exact meaning of this proposition can be in a context that is largely informed by the urgent sense of a problem - the problem of underdevelopment which needs to be addressed. Taken to its final consequences the view according to which history might be an open-ended process would seem to suggest that it is none of development policy's business to meddle in the internal affairs of aid recipient countries. Developing countries, as it were, should be allowed to follow the policies which they themselves choose, even if this means that donors have every reason to fear that they may fail. While this may flow logically from the argument put forward so far, the reality of development aid and

${ }^{12}$ In a study on behalf of DFID on direct budget aid to Mozambique I came to these conclusions (Macamo 2006b). One of the most important objectives of direct budget aid was to ensure ownership. In practice, however, it proved very difficult for donors in Maputo to control their urge to have a say in Mozambican decisions. The result, as other authors also found out (Killick, Castel-Branco and Gerster 2005), was intervention that made Mozambican political institutions utterly irrelevant as donors expected the government and the parliament to simply adopt their recommendations as standing above any kind of political negotiation. 
policy is such that it does not predispose key actors to view matters in a dispassionate way. One reason why passions run high in this regard is, again, the moral investment that has been made in defining the problem of development and the onus which it has since placed on anyone voicing doubts to defend him- or herself against the charge that he or she may be against development. This usually translates into being against the poor, the vulnerable and the protection of the environment.

Peter Singer's (2009) passionate defense of uncompromising aid to the poor may have contributed considerably towards lending philosophical coherence to this rather intolerant attitude. Singer's argument, in effect, is that giving aid is a moral obligation which we owe to ourselves and fellow human beings. There are problems with this position, however, not least, the problem that it is not easy to define these moral obligations as clearly as one may suppose. Legal philosophers have been debating these issues in interesting ways. Ronald Dworkin (2011), for example, has countered this moral obligation with his suggestion that we may be under a stronger obligation to do no harm (see also Appiah for an interesting discussion of the same issues 2006). ${ }^{13}$

Dworkin's claim is that any help can only be justified on the grounds that it does more good than harm. This is not an easy thing to establish. While the injunction to do no harm may be understood as the formulation of a moral obligation that entails, perhaps, refraining from doing things that may please us - e.g. helping others - it is still an open question how it is morally superior to helping those in distress.

Again, philosophers have come up with interesting comments on how to plead for the moral superiority of one obligation over another. The bottom line, and as far as we are concerned in this paper, is that what is at issue in development aid and policy has long ceased to be whether aid should be granted to becoming the question concerning when and how aid should be provide. Peter Singer or Garrett Hardin (1974), however opposite their views may be, address in their work the question concerning whether aid should be provided whereas Dworkin (and Appiah 2006 for that matter) are more concerned with the when and how of the question.

${ }^{13}$ This position should be distinguished from that of the biologist Garret Hardin (1974) who in his so-called "life-boat ethics" argued against development aid on Malthusian grounds. 


\section{The compulsion to do the right thing}

The foregoing discussion focused on the nature of development knowledge. In particular, it made an attempt at uncovering the epistemological foundations of this knowledge. The aim was to ask whether development knowledge is likely to help us understand the challenges faced by Africa currently, especially in the wake of the rise of new donors as well as Africa's own economic revival. In drawing attention to the historicist logic underlying development knowledge the discussion sought to bring into relief a major assumption that may account for the kinds of policy implications that the development apparatus tends to draw. This assumption concerns the implicit belief that since development is the fate of the world and this has been achieved by certain countries, then an understanding of these achievements provides an adequate and sufficient basis for designing the policies which developing countries need in order to develop. This is where the compulsion to do the right thing arises. This phenomenon refers to the strong belief among development institutions and practitioners that positive development outcomes can be achieved through the deployment of the right kind of policies. The fact that many years have elapsed since the world committed itself to developing Africa with modest results does not seem to sway the faith of those who subscribe to this view. The compulsion to do the right thing is based on three fundamental assumptions that constitute themselves as a nexus that binds belief in the fatefulness of development to the practice and policy of development.

The first assumption rests on a causal nexus. The idea is that the world is rationally ordered and, therefore, able and capable of responding to causal stimuli. More specifically, development policy is committed to the idea that development outcomes are a response to a discrete set of factors which rational individuals and institutions deploy against the background of a world that is rational and fair in principle. In other words, all things being equal, the right set of economic and fiscal incentives, institutions and attitudes can make development possible. An extreme manifestation of this assumption is displayed by Sachs (2005), but also by Moyo (2008), none of whom pause to consider the importance of the hedge "all things being equal". The protracted nature of the development process in the West as well as the role of chance in the successful transformation of some South Asian economies from the sixties onwards seem to suggest that the causal nexus may be more of a 
comforting tale than a realistic account of how development happens. Even the optimism with which Africa's prospects are being seen today would appear to suggest that while design may be important in determining development outcomes, there is much that is random in the process of development.

The second assumption refers to an inferential nexus and consists in the idea that more knowledge is better than less knowledge for development. The premise underlying this assumption is that certain aspects of political, social and economic life are liable to control and can indeed be controlled. This explains how the growth of the development apparatus has been in the main the growth of its knowledge base, but also its insatiable hunger for more and more knowledge. The reality behind the growth of the knowledge base, however, is that more knowledge has not necessarily meant that the development apparatus has improved its ability to intervene in ways that bring development closer to developing countries. On the contrary, more knowledge has meant that the development apparatus has become even more aware of what it does not know and, in this way, basically fuelled the search for more knowledge. The pursuit of knowledge in development has been, so far, some kind of wild goose chase. In other words, knowledge has been produced for its own sake. The downside to the inferential nexus is to be found in its political implications. In fact, belief in the controllability of the world paves the way for a suspicious attitude towards politics, especially when these are protective of individual rights and the claims to autonomy that groups and individuals can legitimately make in a democratic polity. It has not been uncommon for development institutions to expect developing countries' governments to implement unpopular policies on the grounds that they are consistent with what is known about the right thing to do.

Finally, there is a self-reproductive nexus that consists in the belief that what is good for the development apparatus is good for development itself and, therefore, for the countries, communities and individuals that are the object of development interventions. This belief conflates, in actual fact, the institutional and manipulative logic discussed by Musto (1986) in his critique of development policy. It is the failure to realize that the formulation of development policy serves foremost the self-reproduction needs of the apparatus itself. The problematic nature of this belief has been abundantly pointed out in the context of humanitarian aid where in a rather cynical manner some authors (Vaux 2001; 
de Waal 1997 - to name just two) have criticized the self-seeking logic guiding the action of relief organizations and donor countries.

In a sense, the compulsion to do the right thing comes from a type of knowledge which makes highly problematic assumptions about the nature of the world. This is another way of saying that development policy and practice, for all its elaborate discourse, jargon and expertise is to an important degree flawed knowledge. It is knowledge that is insensitive to how the world functions and for this reason is particularly bent on remaking the world, especially the world of so-called developing countries, in its own image. The plausibility that development discourse and jargon carries is mostly a function of the success of the apparatus of development to reproduce so-called developing countries in ways that make them amenable to development interventions. Seen in this way, then, it could be said that there is no failure of development on the African continent. There is a failure of the kind of development that development institutions have tried to foist upon Africa. To put it differently, what has failed in Africa is the attempt to engineer development in countries which were transformed by development interventions.

These remarks have far-reaching implications for development research as Africa awakens to a multipolar world. Here I will only discuss two briefly. One obvious implication is the need to revisit our definition of the notion of development. The new definition which is required should be one that would distance itself from teleological assumptions while at the same time being sensitive to the diverse nature of the course which history can take. Methodologically, this would mean that any assumption that the course of any particular country can serve as model from which universally valid principles of development can be derived should be viewed with skepticism. This skeptical attitude does not mean that there is nothing to be learned from any one experience. It solely means that individual experiences will have a limited practical import if they are formulated as general principles. Development, in a nutshell, is a highly idiosyncratic phenomenon that takes place within a political, economic and cultural context which countries share with one another.

From this follows a second implication of a political nature. It is that research should be sensitive to the thick moral obligations (see Walser 2006) that bind individual societies and make them different from others. This means that the meaning of development and the kinds of policies which are required to make it happen are issues that are only locally 
intelligible. They are not intelligible to concepts born out of universal understandings of the problems of the world. This will be a difficult lesson to be digested by the development apparatus with its "constitutive holism", a term coined by Jeremy Gould (2007) to describe the inability of the development apparatus to define and circumscribe its sphere of action such that it does not encompass the whole society. This makes development policy and practice extremely suspicious of local politics as it tends to assume that any articulation of interests running counter to its normative definition of development, as well as its desirability, is actually an assault on development itself. Ultimately, however, academic research on development needs to approach local politics using conceptual and analytical tools that resist the temptation to pass judgment on how local debates over moral obligations undermine or further development and focus mainly on the meanings of development which become visible in such debates.

\section{Conclusion}

In this paper I have tried to explore the possibility of helping to rethink development today by critically assessing the nature of the knowledge upon which development policy rests. While there is little that is new in this critical assessment the contention is that misgivings of an epistemological nature continue to be relevant to any evaluation of the policies, measures and initiatives that are put in place to achieve the goals of development. At a time when more and more research on Africa faces the obligation to contribute towards "development" it is crucial that critical questions are asked of the exact nature of the knowledge that is pursued. Development knowledge not only leads to a compulsion to do the right thing. In emphasizing the solution of problems, rather than their better formulation, it conveys the impression that everything that there is to be known is already known. This is, of course, a direct result of teleological assumptions underlying development knowledge. It is also a reflection of a failure to appreciate the extent of our ignorance and, as such, a poor pre-condition for addressing the challenges which the African continent faces. The least that African studies can do as it searches for a research program that will seek to account for these challenges is to resist the compulsion to do the right thing, as most surely the right thing to do will turn out to be the point at which purveyors of development knowledge stopped thinking. 


\section{References}

Abbas, Hakima and Niyiragira, Yves (eds.) 2009. Aid to Africa - Redeemer or Coloniser? Pambazuka Press. Cape Town.

Abrahamsen, Rita 2001. Disciplining Democracy - Development Discourse and Good Governance in Africa. Zed Books. London.

Allen. Chris 1995. "Understanding African Politics". Review of African Political Economy, Nr. 65, pp.301-20.

Amin, Samir 1990. Delinking - Towards a polycentric world. Zed Books. London.

Appiah, Kwame A. 2006. Cosmopolitanism - Ethics in a World of Strangers. W.W. Norton and Company. London.

Arien, Mack 2010. "From Impunity to Accountability - Africa's development in the 21st century”. In Social Research, vol.77, nr. 4, pp.1048-1459.

Bates, Robert 1981. Markets and states in Tropical Africa: the political basis of agricultural policies. Yale University Press. New Haven.

Bayart, Jean-Francois 1993. The state in Africa: The politics of the belly. Longman. London

Bayart, Jean-Francois et al. 1999. The criminalization of the state in Africa. James Currey. London

Bickerton, C., Cunliffe, P. and Gourevitch, A. (eds.) 2007. Politics Without Sovereignty - A critique of contemporary international relations. University College London Press. London.

Bratton, Michael 1989. "Beyond the state: civil society and associational life in Africa" in World Politics (The Johns Hopkins University Press) Vol. XLI, № 3, April.

Bratton, Michael and van der Walle, Nicholas 1994 "Neo-patrimonial regimes and political transitions in Africa" in World Politics (The Johns Hopkins University Press) Vol. 46.

Brautigam, Deborah 2009. The Dragon's Gift - The real story of China in Africa. Oxford University Press. Oxford.

Browne, Stephen 2006. Aid \& Influence - Do donors help or hinder? Earthscan. London.

Chabal, Patrick and Daloz, Jean-Pascal 1999. Africa works: disorder as political instrument. James Currey. Oxford.

Chang, Ha-Joon 2010. 23 Things They Don't Tell You About Capitalism. Allen Lane. London.

Chang, Han-Joon 2002. Kicking away the Ladder - Development strategy in historical perspective. Anthem Press. London.

Cheru, Fantu and Obi, Cyril (eds.) 2010. The Rise of China and India in Africa. Zed Books. London

Collier, Paul 1997. "The Failure of Conditionality”. In Perspectives on Aid and Development C. Gwin and J. Nelson (eds.) Johns Hopkins University Press. Washington.

Douglas, Mary 2008. Purity and Danger - Analysis of the concept of pollution and taboo. Routledge. London.

Dworkin, Ronald 2011. Justice for Hedgehogs. Harvard University Press. Cambridge.

Easterly, William 2006. The White Man's Burden - Why the West's efforts to aid the rest have done so much ill and so little good. Penguin Press. New York.

Erdmann, Gero and Engel, Ulf. 2006. "Neopatrimonialism Revisited - Beyond a catch-all concept”. GIGA-Working Papers. Hamburg. 
Escobar, Arturo 1995. Encountering Development - The Making and Unmaking of the Third World. Princeton University Press. Princeton.

Ferguson, James 1990. The Anti-politics Machine - "Development", Depoliticization and Bureaucratic Power in Lesotho. Cambridge University Press: Cambridge.

Ferguson, James 2006. Global Shadows - Africa in the Neoliberal World Order. Duke University Press. London.

Gould, Jeremy 2007. "[Dis] assembling Development". In: J. Gould and L. Siitonen (eds.). Anomalies of Aid - A Festschrift for Juhani Kaponen. Interkont Books 15. Helsinki.

Hardin, G. 1974. "Lifeboat Ethics: The Case Against Helping the Poor" Psychology Today 8, 38, 40-43, 123-124, 126.

Jackson, Robert H. 1990. Quasi-States - Sovereignty, International Relations, and the Third World. Cambridge University Press. Cambridge.

Jackson, Robert H., Rosberg, Carl G. 1982. "Why Africa's Weak States Persist - The empirical and the juridical in statehood." In World Politics, vol. 35, nr. 1, Oct. 1-24.

Jha, Vikas et al (eds.) 2011. Citizen Leadership - Deepening democratic accountability in India, Brazil and South Africa. Academic Foundation. New Delhi.

Killick, T., Castel-Branco, C.N. and Gerster, R. 2005. Perfect Partners? The performance of Programme Aid Partners in Mozambique. Report to the Programme Aid Partners and Government of Mozambique.

Lancaster, c. 2007. Foreign Aid - Diplomacy, Development and Domestic Politics. Chicago University Press. Chicago.

Macamo, Elísio 2006a. Political Governance in Mozambique. A Report for DFID: London.

Macamo, Elísio 2006b. "The Hidden Side of Modernity in Africa - Domesticating Savage Lives" in: Sérgio Costa, J. Maurício Domingues, Wolfgang Knöbl and Josué P. Da Silva (eds.): The Plurality of Modernity - Decentring Sociology. Rainer Hamp Verlag: Munich.

McNeil, Mary Malena, Carmen (eds.) 2010. Demanding Good Governance - Lessons from social accountability initiatives from Africa. World Bank. Washington D.C.

Miguel, Edward 2009. Africa's Turn? The MIT Press. Cambridge.

Mkandawire, Thandika and Olukoshi, Adebayo (eds.) 1995. Between liberalisation and repression: the politics of structural adjustment in Africa. CODESRIA Books. Dakar

Mkandawire, Thandika and Soludo, Charles (eds.) 2003 African voices on structural adjustment. CODESRIA/IDRC/AWP. Trenton

Mosse, David and Lewis, David (eds.) 2005. The Aid Effect - Giving and Governing in International Development. Pluto Press. London.

Moyo, Dambisa 2008. Dead Aid - Why aid is not working and how there is another way for Africa. Allen Lane. London.

Murphy, Craig N. Global 2005. Institutions, Marginalization, and Development. Routledge. London.

Musto, Stefan 1987. "Die hilflose Hilfe - Ansätze zu einer Kritik der manipulativen Vernunft." In: Detlef Schwefel (ed.) Soziale Wirkungen von Projekten in der Dritten Welt. Nomos Verlagsgesellschaft. Baden-Baden

Nelson, Joan (ed.) 1990. Economic crisis and policy choice: the politics of economic adjustment in the Third World. Princeton University Press. Princeton.

Pitcher, Anne, Moran, Mary, H. Johnston, Michael 2009. "Rethinking Patrimonialism and Neopatrimonialism in Africa." African Studies Review, vol. 52, nr. 1, 125-156. 
Popper, Karl 1989. The Poverty of Historicism. Ark Paperbacks. London.

Popper, Karl 2011. The Open Society and its Critics. Routledge. London.

Rivero de, Oswaldo 2010. The Myth of Development - Non-viable economies and the crisis of civilization. Zed Books. London.

Rottenburg, Richard 2009. Far-fetched Facts - A parable of development aid. MIT Press. Cambridge.

Rothschild, Donald and Chazan, Naomi (eds.) 1988. The precarious balance: the state and society in Africa. Westview. Boulder

Sachs, Jeffrey D. The End of Poverty - Economic possibilities for our time. The Penguin Press. New York.

Scott, James C. 1998. Seeing Like a State - How certain schemes to improve the human condition failed. Yale University Press. New Haven.

Sen, Amartya, K. 1992. Poverty and Famines - An essay on entitlement and deprivation. Claredon Press. Oxford.

Singer, Peter 2009. The Life You Can Save - Acting now to end world poverty. Random House. New York.

Susini, Marie-Laure, 2008. Éloge de la corruption - Les incorruptible et leurs corrumpus. Fayard. Paris.

Taylor, Ian 2006. China and Africa - Engagement and compromise. Routledge. London.

Ufford, van Philip Quarles and Giri, Ananta K. (eds.) 2003. A Moral Critique of Development - In search of global responsibilities. Routledge. London.

Vaux, Tony 2001. The Selfish Altruist - Relief work in famine and war. Earthscan. London.

Wal de, Alex 1997. "Famine Crimes: Politics \& the disaster relief industry" in Africa. African Rights \& the International African Institute. London

Walle, van de N. 2001. African Economies and the Politics of Permanent Crisis, 19791999. Cambridge University Press.

Walzer, Michael 2006. Thick and Thin - Moral argument at home and abroad. University of Notre Dame Press. Notre Dame.

Whitfield, Lindsay (ed.) 2009. The Politics of Aid - African Strategies for Dealing with Donors. Oxford University Press. Oxford. 


\section{THE STUDY OF AFRICA IN A MULTIPOLAR WORLD A PERSPECTIVE FROM WITHIN}

\section{Ebrima Sall}

In a paper he presented at a Conference co-organized and hosted by the Council for the Development of Social Science Research in Africa (CODESRIA) in January 2013, Achille Mbembe, a one-time executive secretary of the Council, drew our attention to one of the recent books of Jean and John Comaroff, Theory from the South, in which they argue that

"the history of our times" is now made outside of the West, especially in the Southern parts of the world. This being the case, they [the Comaroffs] then ask how does one de-center social theory and the production of knowledge in such a way as to better account for the complexities of modern world history and for the multiple ways in which various parts of the world relate to each other. The project of de-centering theory is not only a response to the colonial event. De-centering theory has been part of a larger quest to rewrite world history (Mbembe 2013: 1-2).

It is a project that has been at the heart of the thinking of all the great pan-African intellectuals, from W. E. B. Du Bois, through Nkrumah and many others, to Cheikh Anta Diop.

De-centering theory and rewriting African and world history is, in some sense what CODESRIA has also been engaged in, all through its 40-year history. Promoting social science research and knowledge production in Africa and by Africans was, as Cabral used to say, a question of encouraging African intellectuals to learn to "think with our own heads, based on our own realities". This has led to the interrogation of theories and the critic of dominant paradigms of development, governance and international relations. ${ }^{1}$

Indeed, one of the challenges facing African scholars has, for a long time, been how to produce counter-narratives and alternative ways of understanding African and global issues as well as representations of Africa and African realities. For CODESRIA in particular, and for many great scholars in or from the African continent, it has also been

\footnotetext{
${ }^{1}$ The 2007-2011 Strategic Plan of CODESRIA was deliberately focused on the critic of development theories.
} 
about the imagining of new futures for Africa and for the world, but a world in which Africa is not a peripheral player, but a key one.

In January 2013, news of the destruction of some of what are now often referred to as the "Timbuktu manuscripts" by the armed groups that had occupied the old city of Timbuktu, in Mali, came as a reminder that Africa has a history of higher education and scholarship that goes back several centuries. The Timbuktu manuscripts and the larger body of knowledges produced by what Ousmane Kane calls "non-Europhone intellectuals", cover a broad range of subjects (Kane 2012; Jeppie and Diagne 2008; Sharawy 2005). What this shows is that the study of Africa and of African encounters and engagements with the rest of the world has, on the continent itself, a long history.

However, it is with the creation of modern universities and the emergence of a networked pan African social science community that scholarly debates began covering contemporary global issues. The building of such a community of scholars at the continental level has, from the start, been among the main objectives of the CODESRIA. A number of other organizations, professional associations, networks and consortia also pursued similar objectives at the level of specific sectors, sub-regions or disciplines. ${ }^{2}$ At the level of some countries, such as South Africa, Nigeria, Ethiopia, Kenya, Senegal and Egypt, one also finds associations and networks of scholars that are engaged in research and academic debates that could be quite vibrant. ${ }^{3}$ These communities grew in size as the numbers of higher education and research institutions increased, particularly during the post-colonial period. It is a known fact that the colonial administrations left only a small number of universities in Africa, such as the universities of Dakar, Makerere, Ibadan and what was to later become the University of Kinshasa.

${ }^{2}$ The Organization for Social Science Research in Eastern and Southern Africa (OSSREA) pursued objectives similar to those of CODESRIA but at the level of Eastern and Southern Africa only; the Association of African Universities (AAU) brings together African universities, but doesn't include research NGOs, nor does it include the regional, sub-regional and national knowledge networks; SARUA is the Southern African equivalent of AAU; the African Association of Women Researchers for Development; (AAWORD) is a pan African network of women researchers only; the African Economic Research Consortium (AERC), the Pan African Association of Anthropologists, the now defunct African Association of Political Science (AAPS), the African Association of Historians, and the African Association of Sociology, are all discipline of subject specific pan African networks.

${ }^{3}$ Associations such as the Ethiopian Studies Association and the Mande Studies Association include both researchers in or from Africa and Africanists based outside of Africa. 
The institutional bases for the phenomenal growth of the scholarly community were therefore established during the post-colonial era.

The creation of national, discipline based and regional research associations and councils was not fortuitous: it came out of the efforts of specific institutions and certain individuals who felt the need for such associations and councils. Both at the country level and at the sub-regional and pan African levels, the formation of research or discipline-based associations was done with a view to increasing the production of knowledge and/or to facilitate networking and scholarly exchanges and debates. That certainly was the case with CODESRIA. The research agenda and the themes of the scholarly debates evolved with what were seen at each given moment to be the main challenges for the continent or for specific sub-regions and countries, and therefore for research as well.

In this chapter, I discuss CODESRIA's experience in the promotion of social science research in Africa and in encouraging African contributions to debates on Africa's development challenges and on global issues. The specific questions I try to answer include the following: What difference has the shift from a unipolar or bipolar world to a multipolar world brought about in the way Africans are studying Afri$\mathrm{Ca}$, and in the debates on African and global issues that are going on in Africa? ${ }^{4}$ I begin with the epistemological issues, before looking at the changing context, and then at African engagements with the BRICS as an illustration of African engagements with the multipolar world. Two of the major concerns that have been part of the raison dêtre of much of the work carried out by African scholars have been autonomy (not independence) in the practice of social science research, but also of the African continent, and social transformation and sustainable, democratic and equitable development.

\section{Creating space for African Research, within Africa and globally}

Paul Tiyambe Zeleza's two-volume book on The Study of Africa shows how difficult it is for one to make a clear distinction between the way Africans are studying Africa and the way Africa is studied in the rest of the world (Zeleza 2006; 2007). There are many reasons for this.

\footnotetext{
${ }^{4}$ Representations of Africa in the multipolar world are also discernible in the films, literary works, songs and paintings, and in other works of art produced on the continent.
} 
The first has to do with the growth and diversification of the field, with a diversity of sites and actors:

Clearly, today African studies or the study of Africa is a vast international enterprise comprising Africa itself, the former colonial powers of Western Europe, countries with large African diasporas in the Americas, as well as countries in Europe and Asia that have had no overt relations with Africa (Zeleza 2007a, 22).

Secondly, the institutional frameworks are certainly different: 'areas studies' constitute the framework within which a good part of the study of Africa in universities and research institutions in North America and Europe, as well as in other regions of the world is carried out; on the contrary, in Africa, 'area studies' are much less important, and the bulk of the research on social processes, development, governance, culture and other issues or phenomena is going on in the disciplines and in multidisciplinary fields of study (Zeleza 2007 Vol. II). There is also a difference in the kinds of debates, or rather, in terms of what tends to be emphasized in the academic debates. However, although the location from which the study of Africa is being carried out is important, the epistemological issues seem to be more important, and the epistemic communities that the scholars engaged in the study of Africa are part of tend to play a determining role in the shaping of their perspectives. Seminal works such as Valentin Mudimbe's The Invention of Africa (Mudimbe 1988) and The Idea of Africa (Mudimbe 1994), like Edward Said's Orientalism, and Enrique Dussel's The Invention of the Americas (Dussel 1976) were, with the exception of Dussel's, written by scholars based in the USA. ${ }^{5}$ Samir Amin, the author of Eurocentrism (Amin 1988), and the person who organized and hosted the meeting at which CODESRIA was formed in 1973, is based, and has for the past few decades, lived in Dakar. One can also find critiques of Eurocentrism and of what Mudimbe calls the "colonial library" in the Euro-American Africanist community (Mudimbe 1988; Mudimbe 1994). However, what Mudimbe, Said, Dussel, Amin, Mamdani, and others have demonstrated in their work is how the study of the Africa, the Americas and the Orient has been, and in the case of Africa, continues to be influenced by scholarship in the West. Mudimbe, for instance, has argued that

Western interpreters, as well as African analysts, have been using categories and conceptual systems that depend on a Western epistemological order. Even in the most explicitly 'Afrocentric' descriptions,

\footnotetext{
${ }^{5}$ Enrique Dussel is from Argentina, but is based in Mexico.
} 
models of analysis explicitly or implicitly, knowingly or unknowingly, refer to the same order (Mudimbe 1994, xv).

Thirdly, the 'colonial library' has left a strong imprint on the way Africans in Africa study Africa (Mudimbe 1988; Mudimbe 1994). The colonial library did not disappear with the demise of colonialism, given that aspects of it have metamorphosed into the postcolonial constructions of Africa as an object of study. ${ }^{6}$ Therefore, beyond the colonial library, there is what Zeleza calls a "Euro-American epistemological order" (Zeleza 2007a: 2), and that order has now become a more or less global order, and the study of Africa by Africans is strongly influenced by that order:

... the Euro-American epistemological order remains central in the African academy.Since the colonial encounter, the construction of scholarly knowledge about Africa has been internationalized both in the sense of it being an activity involving scholars in various parts of the world and the inordinate influence of externally generated models on African scholarship (Zeleza 2007a, 2).

Part of the explanation for this resides in the fact that both the social sciences and the modern universities which, historically, have been the homes of the social sciences, have European origins. Both also came to Africa through the colonial encounter. For the social sciences, which are products of the European enlightenment (Mamdani), this is not surprising. An important consequence of the introduction of modern social science and the modern university has been the near total marginalization of the old intellectual traditions, 'libraries' and universities that existed in the continent.

Fourthly, the active involvement of a large African academic diaspora in the study of Africa makes it even more difficult to make the distinction (Zeleza 2007b).

However, although it has become more or less globalized, the "Euro-American epistemological order" is a contested order, and the contestations exist both within Africa and in other parts of the Global South, as well as in the West itself. What makes the issue more complex is the fact that part of the contestation is made with the same 'Western' / Euro-American theories and concepts. Mudimbe explains this in the following terms:

${ }^{6}$ This came out very well in many of the papers presented at a CODESRIA-Point Sud international colloquium on the theme: Africa N'Ko, Africa in the World: Debating the Colonial Library. 
The idea of Africa presented in this book may seem, indeed, too dependent upon Western texts. Nonetheless, I think this choice makes sense. To comprehend the archeological organization of this very idea of Africa and its resonances, it seems to me, it is impossible not to consider Western literature and, particularly, its culmination in the "colonial library" ... as Immanuel Wallerstein notes: "the capitalist world-economy, posing the question of whether a set of ideas, or a way of thinking, is universal [European] or African returns us only to the double bind which the system itself has created. If we are to get out of this double bind, we must take advantage of the contradictions of the system itself to go beyond it" (1988: 332) (Mudimbe 1994, 213). ${ }^{7}$

Both the "knowledge divides" that are highlighted in the 2010 World Social Science Report (WSSR 2010), and the dominant trends in the internationalization of higher education (Zeleza 2012; Mustapha 2012) are evidence of the fact that, like the multipolar world we live in, the higher education and knowledge production fields have also become much more complex in this second decade of the 21st century than they were in the fifties and sixties of the last century.

The CODESRIA story, I would argue, is also a story of how, at the pan African level, a community of scholars has been engaged in the struggles that are aimed at transforming the dominant epistemological order, and bridging some of the global "knowledge divides" (WSSR 2010). Those struggles are going on in many parts of the world and are often conceived of as being part of the larger struggle aimed at "transforming global relations for a just world". Indeed, for CODESRIA, the aim has from the start been to promote excellence in scholarship while ensuring that our scholarship not only speaks to African realities, but also remains socially relevant. The starting point, however, was an expressed need to excel in social science research, and negotiate a space for African scholarship in the global epistemological order, which is why, until today, a number of CODESRIA programmes are intended to enable young African scholars to be familiar with the classics of social science (including the African classics) as well as the more recent publications, enhance the research capacity of the new generations of scholars through a greater mastery of research meth-

${ }^{7}$ Partha Chatterjee, in his Nationalist Thought and the Colonial World: A Derivative Discourse? makes a similar observation about the Gandhi's critique of the West.

${ }^{8}$ The role of the social sciences and humanities in the transformation of global relations for a just world is the theme of the 2015 World Social Science Forum that will be held in Durban, South Africa. The theme was proposed by CODESRIA and the Human Sciences Research Council (HSRC) of South Africa, who will be the hosts of the Forum. 
odologies, and publish in both African journals and those published in other regions of the world. CODESRIA now publishes twelve scholarly journals, both as a way of responding to the politics of scholarly publishing at the global level, but also to avoid leaving the business of scholarly publishing to others, and therefore losing a chance to have a say in what is publishable or not; i.e. what is quality scholarship or not.

The Kampala Declaration on Intellectual Freedom and Social Responsibility, adopted in November 1990 by participants in an international symposium organized by CODESRIA has a whole section devoted to the social responsibility of the intellectual, and the inclusion of that section in the Declaration is what really differentiates the Kampala Declaration from the Lima Declaration on Academic Freedom adopted in 1988, and other international declarations on academic/ intellectual freedom. Academic freedom has never been a given in the African context (nor has it always been in other contexts as well). The struggle to break "local barriers and negotiate international presence" (Mkandawire 1997) for the social sciences in Africa and for African scholarly voices has been a key part of what explains the very existence of CODESRIA. The restrictions on the freedom of research were many, given the prevalence of authoritarian regimes (military regimes, single party regimes, life-presidents ...). The Kampala conference referred to above also identified civil society movements, donors and academics themselves as potential sources of violation of academic freedom (Diouf and Mamdani 1994).

However, it was also felt that academic freedom had to come with social responsibility. The view that scholarship has to speak to the social transformation, governance and development challenges facing Africa is quite widely shared. As Thandika Mkandawire put it, "social science is not for monkeys. It is for human beings" (cited in Sall 2003:11. The explanation for this partly resides in CODESRIA's own history, which I now turn to.

\section{CODESRIA in a Changing Context ${ }^{9}$}

The problems that those who met in 1973 to set up CODESRIA tried to address through research were those of the absence of freedom for scholars and autonomy for the public universities; the fragmentation of the community of scholars along disciplinary, linguistic, regional,

\footnotetext{
${ }^{9}$ This section is a revised version of a section of CODESRIA's 2012-2016 Strategic Plan.
} 
gender and other lines; the political fragmentation, poverty, dependence and low level of development of the continent; and, as a consequence of these problems, the marginalization of Africa and Africans (including the scholarly community), in global affairs. These problems were largely due to the centuries of domination and plunder that Africa had been subjected to through colonialism, trade (including trade in humans), and other mechanisms through which natural, human and intellectual resources of the continent were taken away, forcefully or otherwise, thus leaving the continent's people poorer, poorly governed, and deprived of independence and freedom. Policy making for development, regional integration, greater freedom, and international presence was not only difficult, but also not really informed by African research. Many of the leading higher education institutions such as Dakar University and Makerere University had hardly ceased to become extensions of French and British universities, and the curricula and research were dominated by paradigms, concepts and theories that came from the West. African scholarly voices were hardly audible at the global level. The geopolitical fragmentation of Africa, together with the multiplicity of boundaries of a geopolitical, linguistic and disciplinary nature, made it impossible for there to be a an integrated, self-aware, pan African scholarly community that could effectively produce knowledge and interpret social realities in Africa and in the world around us from African perspectives, and inform public decision making (including at the regional level) with the research it is doing.

Four decades after the creation of CODESRIA and more than half a century after the wave of decolonization that swept through the continent in the late fifties and early sixties, there is now a well networked and productive community of scholars in Africa. The research environment and the larger socio-political environment are characterized by a number of contrasting phenomena and contradictory trends indicating both the persistence of huge challenges and the emergence of new ones. There are also many positive developments and a lot of opportunities for research to take advantage of.

The African community of scholars has grown, with a much broader and more diversified institutional base that includes many more public and private universities and other research institutions, but also more think-tanks and research networks; and many more researchers and public intellectuals. Beyond the numbers, the African social re- 
search community is also more self-aware, more self-confident, and less "defensive" in its relationship with the rest of the global scholarly community (Mkandawire 1997; Macamo 2009); It has succeeded in "bringing the production of knowledge about Africa back into the continent" (Boulaga 2009,1) and, in so doing, the division of labor once criticized by Paulin Hountondji that pitched empirical material collected in Africa against theorizing carried out in Europe has been made to loosen its grip on African studies. Many African scholars established themselves in the eighties as competent theoreticians and are widely quoted in relevant fields (Macamo 2009, 2).

However, the global epistemological order still favors Western scholars and the study of Africa (including by African scholars themselves) is still dominated by theories and paradigms developed in Europe and North America (Mudimbe 1994; Zeleza 2007). Furthermore, as some of the "competent theoreticians" from Africa are nearing retirement, the emergence of new "competent theoreticians" has been more difficult, partly because many African universities are struggling to maintain high standards despite the massification, loss of good academic staff to the rising numbers of private universities, brain drain, the consultancy syndrome, and lack of resources for academic research.

Furthermore, Africa is, until today, a politically fragmented continent in which the institutions of many of the states are, in some strands of the academic and development agency literature, classified as "fragile". ${ }^{10}$ The splitting of Mali into two during the first quarter of 2012 and the occupation of more than half of its territory by forces whose commitment to democracy or to the territorial integrity of the country is questionable, and the conflicts in Darfur, the Democratic Republic of Congo, Côte d'Ivoire and in other countries are all indications of political fragmentation, itself often being a consequence of the denial of the rights and freedoms and insecurity of citizens.

What Mkandawire calls the "unholy trinity of poverty, ignorance and disease" (Mkandawire 2009, 1) that all African nationalists have been seeking to eliminate is still a major challenge. Decades of structural adjustment and neoliberal globalization have significantly reduced the developmental role of African institutions, particularly the African state, and liberalized trade in ways that make the prospects

${ }^{10}$ The notion of state fragility is highly contested; The European Report on Development 2010, for instance, classifies 27 out of the 53 African states as "fragile". 
for industrial development seem dimmer. The extreme vulnerability to global and local hazards that Africa is facing; and the asymmetries in power, wealth and influence make the challenge, for African countries, of having to develop under less than optimal global conditions no less formidable today than it was nearly 40 years ago.

The new global challenges that African scholars are also researching and debating include climate change. Global responses to the challenge have however also entailed the commoditization of part of the commons, such as forests, and transfer of costs to the South, paying little attention to issues of sustainability (Wen 2011), or to the involvement of local communities in the South in the programmes that are supposed to mitigate the adverse effects of climate change. CODESRIA has been involved in several South-South initiatives such as the South-South tri-continental research programme that it jointly manages with the Latin American Social Science Council (CLACSO) and the International Development Economics Associates (IDEAs, based in New Delhi), the South-South Exchanges on the Histories of Development (SEPHIS), and the South-South Sustainability Forum (coordinated from Beijing and Hong Kong). In 2011, CODESRIA, the International Union for the Conservation of Nature (IUCN) and the Department of Geography of the University of Illinois at Urbana Champaign together launched a Responsive Forest Governance Initiative (RFGI), which is an environmental politics and governance research programme that is looking at the extent to which local communities in the South, particularly Africa, are engaged in decision making in matters of natural resource governance that affect them directly, and how global programmes like REDD, REDD+ and RED$\mathrm{D}+{ }^{11}$ could be improved through the strengthening of institutions of local democracy such as the local councils and their inclusion in decision making on matters of forest governance.

However, the "knowledge divides" that have been highlighted in the 2010 World Social Science Report (WSSR 2010) and the fragmentation of research in Africa mean very unequal capacities for the sciences to address challenges such as global environmental change; the social sciences and humanities being less favored by the policymakers,

\footnotetext{
${ }^{11}$ REDD stands for Reducing Emissions from Deforestation and Forest Degradation; according to UN-REDD, "'REDD+' goes beyond deforestation and forest degradation, and includes the role of conservation, sustainable management of forests and enhancement of forest carbon stocks"; REDD++.
} 
and among the social sciences and humanities, certain disciplines are at a real disadvantage. It is the case of History, Ethnology, etc.

Since the beginning of the New Millennium, some African economies have also been among the fastest growing economies in the world (UNCTAD Economic Development in Africa report 2012; UNECA-AU 2012; IIAG 2010). There has been significant progress made in terms of infrastructure development and provision of education and health services; life expectancy has been increasing. There are also many positive new developments in and around the African Union (AU), and the African Regional Economic Communities (RECs), indicating awareness of the need for, and renewed interest in moving towards greater regional integration. There has also been great progress towards the institution or consolidation of democratic governance (the Arab Spring; Ghana; Senegal; South Africa; Botswana ...) and, in a few cases even, democratic and developmental governance (as in Cape Verde; and Mauritius). Growing citizen awareness and engagement, particularly of the youth, as could be seen in movements ranging from the Arab Spring, to the Y'en a Marre! [We are Fed Up!] movement led by young rap musicians and journalists that played a major role in the struggles for peaceful and democratic change in Senegal in 2011 and 2012. The ICTs revolution and the creative use of new technologies and social media in trade, industrial and agricultural development, research, teaching, etc. and in social and political action have also created new opportunities for research in and on Africa.

What this means is that the study of Africa and African engagements with the rest of the world is more and more being done not only from within the African continent, but also, in a number of cases, with a view to taking "our social contexts seriously enough to derive epistemic analysis from them" (Adesina 2006:143.) as a necessary step towards engaging dominant theories and paradigms and contributing to the production of knowledge at the global level. One question that this raises is that of how the growth and development of the social science research community in Africa impacts on the scholarly debates about African and global issues, but also on the evolution of the social sciences and of the humanities as disciplines.

The number of universities has been increasing at an extremely rapid pace. From a few dozens in the early 1960s when many African countries were obtaining their independence, we now have thousands of higher education institutions. In the Democratic Republic of Con- 
go alone, there are more than 1,000 universities, many of which are small, private institutions. The latter, in most countries, have outnumbered the public universities.

As the number of African higher education and research institutions engaged in the study of Africa and Africa related issues grows, the nature of the conversations between those studying Africa from within and those who are based at institutions outside of the continent is also likely to evolve. The roles that CODESRIA has been playing include the facilitation of these conversations, but also the amplification of the African scholarly voices.

Although Africa still occupies a subaltern position in global relations, the shift away from colonial and neocolonial relationships towards what could be called a multiplicity of 'partners' does make a difference. Yet, the debates over the intervention of French troops to stop Islamist groups from marching on the capital of Mali, Bamako, show that notions of spheres of influence (what used to be referred to as France's close circle of African 'friends', or rather, 'dependencies' (the so-called pre-carre, also known as 'pays du champ', for instance) are to a certain extent still pertinent. What seemed to be new about that intervention was not so much in what motivated it (the defense of France's strategic interests in the Sahel - including access to resources - and the security of French citizens (in the face of the risks of hostage taking), but in the fact that it was presented as a response to an urgent request from an African head of state (Dioncounda Traore, transition president of Mali). Before sending the French troops to Mali, the French president personally called several African Heads of State, including Jacob Zuma of South Africa, to seek their approval of the move. This too was a departure from 'common practice'. During the Cold War period, typically, consultations would be held mainly with other European powers (particularly the United Kingdom and Portugal) and the USA, given that the understanding was a sharing of responsibility for the 'oversight' of African countries among the former colonial powers (the UK, France, Portugal and Belgium), the USA and what used to be the USSR). These days, the African heads of state are also consulted. The problem, though, is that 'history', as far as Africa was concerned, was understood as an externally driven process. 
Internationalization in higher education (HE), and the infusion of a market logic in the higher education sector, the commoditization of higher education services, and the marketization of the social sciences themselves have reached unprecedented levels (Zeleza 2012; Burawoy 2007). The factors driving the process of internationalization in higher education include the search for students from the South, but also for some kind of global presence that one finds in many universities of the North, the problems of access to quality higher education among the middle classes of the South; and the policies of the World Trade Organization, such as the GATS and the TRIPS aimed at making higher education and health services tradable commodities (AAU 2004). The African continent is nowadays host to many campuses ('branches') of American and European universities.

The gulf between world class universities and the vast majority of the universities in Africa - whose numbers are growing very rapidly with the creation of hundreds of new public and private universities - is huge. As the leading universities such as Harvard and Oxford are trying to find ways of consolidating their positions at the top of the global HE pyramid in the face of China's attempts to 'buy' the best professors and researchers for its universities, the risk that many African universities will become mere consumers of course modules and course materials developed elsewhere is very real (Mustapha 2012). This poses enormous challenges for social science research in Afri$\mathrm{ca}$ and for CODESRIA in particular. One possible consequence is the widening of the "knowledge divides" highlighted in the World Social Science Report 2010.

The relatively new phenomenon of Massive Online Open Courses (MOOC) which, in part, is about the use of the Internet by prestigious higher education institutions in the USA, like Harvard and Massachusetts Institute of Technology (MIT), to upload courses on their websites that are easily accessible all over the world, is a formidable opportunity for all the universities that are struggling to get good pedagogical material to improve their programmes (CNAES 2013). However it increases the risk of intellectual dependence on the part of the universities of the South.

With all these and many other new developments, a widely shared view, judging by the number of initiatives, is that the condition for 
African universities to survive and remain competitive in the contemporary global environment is to strengthen their Ph.D. programmes. The challenge of nurturing new generations of scholars has been extensively discussed, and many initiatives launched over the past ten to fifteen years. The new developments include:

i. the proliferation of private universities that have outnumbered the public universities and, although they have broadened access to higher education, they continue to make the upholding of high academic standards in the public universities very difficult;

ii. the strong determination of some African governments (South Africa and Ethiopia are good examples; like Brazil in south America) to increase the numbers of $\mathrm{PhDs}$ produced by their universities in very dramatic ways;

iii. the increase in the number and diversification of the responses to the crisis of higher education, and attempts to strengthen $\mathrm{PhD}$ programmes:

iv. The proliferation of "doctoral schools" (ecoles doctorales) in the Francophone countries;

v. The African Doctoral Academy at Stellenbosch University in South Africa:

vi. OSSREA's Research School (RESSESA), linking several African universities;

vii. The Adoption of a Charter for the Humanities and Social Sciences by the South African Ministry of Higher Education that is really about strengthening higher education and social research in South African universities

viii. SANPAD's pre-PhD and $\mathrm{PhD}$ training programmes and writing workshops;

ix. Attempts to build strong doctoral programmes based on course work at Makerere, Addis Ababa University, etc.

"Older" initiatives such as some of CODESRIA's programmes (the summer institutes, small grants for thesis writing, faculty seminars, methodology and scholarly writing workshops, the text book programme, the training trainers programme, the advanced research grants, the deans' conference, social sciences campus, ...), and the 
AERC's MA and $\mathrm{PhD}$ programmes in economics involving several universities, are also still going on. Furthermore, although it is not focusing exclusively on the $\mathrm{PhD}$ level, the programmes of the African Union's newly established Pan-African University will be good additions to the efforts to address the problems of the new generation of scholars. A number of universities have also become much stronger than they were during the years of higher education crisis, and a few private universities are also doing very well.

Another new phenomenon is the tendency to try to respond to the crisis of higher education in Africa by prioritizing what Joseph Higgins calls the STEM (science, technology, engineering and mathematics) ( CHSS 2012; CNAES 2013). This is part of the search for 'relevance' and 'excellence' understood in more or less market terms. Although it is often argued that prioritizing the STEM doesn't mean neglecting or minimizing the importance of the social sciences and humanities, ${ }^{12}$ in South Africa, the consequence of such a policy choice has been seen to be largely negative for the social sciences and humanities; so much so that the both the Academy of Science of South Africa (ASSAf) and the relatively newly established Ministry of Higher Education and Training felt the need to set up a task teams to produce a report (ASSAf) and a Charter for the Humanities and Social Sciences (CHSS, the Ministry).

The promotion of the STEM is contributing to the emergence of what seems to be a "global higher education space", ${ }^{13}$ a process that seems to be leading towards the dominance of certain conceptions of higher education and the role of universities, norms of quality, and relevance. That process is driven by many factors that include the Bologna process that has led to the adoption of the Licence, Maitrise, Doctorat (LMD), in Francophone Africa; and the global ranking of universities that have sparked off fierce competition among the universities.

${ }^{12}$ The is what the Comite de Pilotage de la Concertation nationale sur l'Avenir de l'Enseignement Supérieur au Senegal (National Dialogue on the Future of Higher Education in Senegal) argues in the pre-report of the National Dialogue, held in Dakar on 6-9 April 2013.

${ }^{13}$ This was the theme of the 2011 edition of the annual conference of deans of social science, humanities and education faculties, held in Rabat, Morocco, in December 2011. 


\section{Encountering the BRICS}

The emergence of the BRICS is perhaps the best illustration of the fact that the world has become "polycentric"; i.e.; a multipolar world (see Amin 2009, 2011), a world that is very different from the world of the Cold War years. Some of the emerging powers are actively engaged in what has been called a "new scramble" for Africa and African land, mineral, and intellectual resources; at the same time, the engagement of China, and other countries of the BRICS with Africa has also created policy space and led to the significant developments in infrastructure that have been going on over the last ten to twelve years.

The multiplicity of partners and interlocutors does have an impact on social and political processes within the continent, as well as on the kinds of engagement that Africa has with the rest of the world. For instance, there is growing interest among scholars in the impact of the heightened interest and increased engagement that China has in Africa, particularly as it creates 'policy space' for African governments. There is a growing body of literature on the BRICS. However, much of the literature on the relations between the BRICS and Africa is produced outside of Africa. A review of 900 more or less recent publications on China-Africa relations revealed that only 7 per cent of that literature was produced in Africa (Salih 2011). What this means is that policies related to China-Africa relations are informed by knowledge produced outside of the continent. For instance, one wonders where the knowledge informing the African Union, as the latter negotiates partnership agreements with China, India, Brazil, Turkey, the European Union and Latin America, is produced.

The main reason for this imbalance between the literature on African encounters with the BRICS produced in Africa compared to the one produced outside of Africa has to do with the structure and orientation of the African higher education and research systems. Many of these systems are rather inward looking, and have little room for the study of other regions of the world. For instance, there is just about a handful of research centres (like the Chinese Studies Centre at Stellenbosch University) which are primarily oriented towards the study of non-African countries or other regions of the world. Yet, with globalization, it is difficult to imagine how Africa as a region and African countries can compete with other regions and countries if the knowledge of their trade partners, for instance, and capacity to understand global dynamics and 
identify opportunities and threats are not robust enough. The universities are where much of that capacity is built and reproduced, which is why the UNESCO-World Bank Task Force on Higher Education and Society (TFHES) in its report titled Higher Education in Developing Countries: Peril and Promise, argued that every country should have at least one good research university (TFHES 2000). African universities, as we know, have been through difficult times, particularly during the 1980s and 1990s. The economic crisis of the 1980s and the effects of the structural adjustment policies (SAP) that were implemented as remedial measures have had a negative impact on the universities, as budgets were reduced precisely at a time when student numbers were increasing. The problems were aggravated by the creation of many new public and private universities around the continent without a corresponding investment in the training qualified academic staff. The result was not only a lowering of standards, but also a loss of capacity in many of what used to be the best universities, such as Dar es Salaam and Makerere. ${ }^{14}$

Part of the explanation for the thinness of the body of literature on other regions of the world produced from within the African continent is also in the nature of the funding regimes. Few are the governments that give sufficient funds for research, and the available funding, with very few exceptions, seldom allows an African researcher to travel to countries like China to do field work.

However, on China-Africa relations, the situation is changing very rapidly, as several organizations and research centres and institutes have embarked on the study of China - Africa relations. ${ }^{15}$ CODESRIA has also launched studies on China's presence in Central Africa (a CODESRIA Comparative Research Network coordinated from CERAPE, in

\footnotetext{
${ }^{14}$ At the turn of the Millennium, a study on four East and Southern universities (Dar es Salaam, Eduardo Mondlane, Makerere and the University of Zimbabwe), supported by SIDA, it was found out that $80 \%$ of the academic staff of the University Dar es Salaam, and $40 \%$ of the staff of Makerere had PhDs (Sall, Yap and Fellerson 2002). The study on University of Dar es Salaam presented at the 10th OSSREA Congress in 2010 revealed that the number of PhD holders among the academic staff of that university had fallen to just over $40 \%$ (Mwinyiwiwa, B.M.M. 2011), mainly because many of the professors had left to head whole universities or be deans and heads of department in the many new public and private universities.

${ }^{15}$ In addition to the work being done by the Chinese studies Centre of Stellenbosch University, other institutions are also seriously engaged in the study of China-Africa relations; these include the South African Institute of International Relations (SIIA, where there is a vibrant research programme on China-Africa relations), and the African Economic Research Consortium (AERC, who carried out a series of 'scoping studies' on China's presence in Africa).
} 
Brazzaville, Congo), a study of Chines communities in Senegal and Mali; and a study on Chinese Investments in Senegal and Mali. In 2011, following a conference that brought together 50 African research institutes and centres, and some Chinese scholars organized by CODESRIA, the decision to create a Forum for the Study of China, and China - Africa Relations was taken. Beyond China - Africa relations, the Forum will also be encouraging research and academic and policy debates on the BRICS.

Development remains a key concept in the thinking on social transformation that translates into greater freedom and the enhanced well-being of the peoples of Africa. ${ }^{16}$ The understanding of development that has now become widely shared among members of the CODESRIA and African research community is the result of a combination of post-structuralist, ecological, gender and southern critiques of the dominant modernization and development paradigms, and years of re-thinking development both as a concept and as a socio-historical process. As Amin has argued, development, for us, is not so much about "catching up", but "an invention of another kind ..., a process of inventing a new civilization" (Amin 2007, 1151), a civilization that is founded on core universal values, and is necessarily human and humane, democratic, "ecological" (Wen 2011), and based on rights, justice and equity, particularly gender justice and equity. Put differently, development is "a response to the many challenges the continent has faced over the years and still faces today" (Mkandawire 2011). The Burkinabé historian Joseph Ki-Zerbo also reminded us more than two decades ago that there is no "read-made development" (développement clefs-en-main) that could be bought or easily transferred from one part of the world to another, and that the key to development is in the people, their cultures, values and worldviews (développement clefs-en-tète; Ki-Zerbo 1990).

However, there has also been, and there still is today a widely shared conviction among African nationalists, scholars, policymakers and activists, from the early days of independence to now, that in the search for responses to the many challenges facing Africa, time is of essence; i.e. that the responses have to be found urgently. In a speech he gave in the early sixties, Mwalimu Nyerere said that Tanzanians and other Africans "have to hurry up". Nyerere is also quoted saying that Africa will have to "run while others walk" (cited in Mkandawire 2011, 9).

${ }^{16}$ This and the next two paragraphs are a revised version of a section of the 20122016 CODESRIA Strategic Plan. 
This contrasts with the notions that "there are no shortcuts to progress" (Hyden 1983), and "no short-cuts to democracy" (Copans 1990).

The growing interest in China and Brazil that exists today among many African scholars, policy makers and development practitioners is, I would argue, partly due to the fact that China and Brazil (and other countries such as South Korea and, to a lesser extent, Turkey) seem to have found appropriate answers to some of the problems of mass poverty and development that Africa is facing and, in the process, demonstrated that it is indeed possible for countries and societies of the Global South to achieve great improvements in the living conditions of large numbers of people within relatively short time spans - i.e. accelerate the development process. Therefore the research that CODESRIA is currently trying to promote includes research on the BRICS, but also on ongoing attempts as well as alternative pathways towards social transformation and development. How to move Africa out of the margins or the periphery onto the centre stage in matters of global trade, knowledge production, development and global governance, without compromising the rights and core universal principles and values as well as the "shared values" identified by the African Union in 2011, finding appropriate responses to the challenges and taking advantage of the opportunities for democratic governance and sustainable development under the current global system, as well as those associated with global environmental change; will also remain key issues for CODESRIA. The successes and failures will also be analyzed.

The BRICS, however, are all following a capitalist development path, albeit with strong social democratic traits in some of them. The models of development in most of them have also been critiqued for their shortcomings from an ecological, a labour, human rights, and a gender justice and equity point of view. Therefore, although China and Brazil seem to have found effective ways of industrializing and transforming their economies, and reducing poverty and the big social inequalities that characterized Brazilian society in particular, the issue of whether or not the only future we can envision for Africa and the Global South is that of a capitalist and an imbalanced society, still arises. Still, CODESRIA has been looking at the experience of the emerging economies of the South from various angles, including that of the very "feasibility of democratic developmental states in the South" (Omoweh 2012). ${ }^{17}$

${ }^{17}$ This was the theme of a South-South research workshop hosted by CODESRIA, and the title of the book that came out of the workshop. 
If our scholarship is to serve the vast majority of African peoples, it has to continue interrogating the development policies and models that our governments are promoting. This was what led to the critical discussions on the New Partnership for African Development (NEPAD; see Adesina, Graham and Olukoshi 20062006). Science can serve the dominant classes, but it can also be the key to emancipatory development.

\section{Concluding Remarks}

The emergence of a multipolar world has very clearly impacted on the ways African scholars have been approaching African and global issues. However, the multipolar world is also the world of heightened globalization, climate change and other phenomena. If research themes have become more diversified and now include many new themes such as climate change, the ICTs and the BRICS, the perennial issues of poverty, conflict, governance, economic development and gender are still very important items of the African research agenda. This shows an ability to both explore current issues, but also continue working on other important issues that may or may not be seen as 'fashionable' elsewhere.

The study of the multipolar world is also increasingly being done in the context of South-South, and North-South research partnerships. In the case of the former, the explicit objective is to join efforts to bring Southern scholarly voices to bear on global issues.

The arrival of the BRICS on African shores continues to generate great scholarly interest, as it does with the policymakers as well. China's massive engagement with Africa has often been analyzed as creating 'policy space' for African governments, for the latter now have more options (Cheru et al. 2010). At CODESRIA, the emergence of the BRICS, and the engagement of African scholars with scholarly communities of these countries are also seen as an opportunity to rethink not only development and development strategies, but also the role of the state, governance, institutional arrangements, social policy, industrialization, and so forth and so on. In other words, as creating new "intellectual space", as the immediate past president of CODESRIA, Sam Moyo, put it during the first convening (by CODESRIA) of a Forum of Research Institutions and Think Tanks for the Study of China, and China - Africa Relations in March 2011. 
In all this, development and the negotiation of a respectable position in the global community seem to be among the key concerns, and African scholarly interest in the BRICS, for instance, is primarily driven by that concern. Development was also the main issue that the scholarly community had with the Bretton Woods Institutions during the SAP years. The reasons for challenging the Washington Consensus were mainly from the point of view of the potential and actual negative impacts that they were having or likely to have on Africa. It could also be safely said that the reasons for the skepticism towards the BRICS that is also clearly discernible in some strands of the literature on China-Africa relations is mainly related to the risks for Africa associated with what is largely perceived as a 'new scramble' for the continent's natural, intellectual and other resources.

I return to the issue of de-centering theory. CODESRIA work has been about taking the West as not being the sole or main centre of the world. It has been and still is part of the effort to do research and publish scholarly journals as if history is being made in many other places outside of the West. That is what led to attempts to develop academic freedom charters, create debating forums such as the Africa Review of Books and other kinds of knowledge platforms, develop alternative journal indexation systems, etc. and participate in the much larger struggle for a more open, inclusive, and equitable global epistemological order, and for making knowledge truly universal.

\section{References}

AAU 2004. "The Implications of WTO/GATSfor Higher Education in Africa”; Proceedings of Accra Workshop; Accra: AAU.

Amin, S. 1988. L'eurocentrisme: Critique d’une idéologie. Paris: Anthropos.

Adesina, J. 2006. "Sociology, Endogeneity and the Challenge of Transformation", in African Sociological Review, Vol. 10 No.2.

Adesina, J. 2009. "Research Priorities for CODESRIA, An Aide Memoire"; paper for CODESRIA Brainstorming Workshop on New Directions and Priorities for Research; July 2009.

Adesina, J. Graham, Y. and Olukoshi, A. 2006. Africa and Development Challenges in the New Millennium: The NEPAD Debate. Dakar and London: CODESRIA and Zed.

Amin, S. 2012. "Responding to Internationalization: Comments on A.R. Mustapha's presentation on Internationalization at the CODESRIA Strategic Planning Workshop."

Amin, S. 2010. Global History: A View from the South. Oxford and Dakar: Pambazuka Press and CODESRIA. 
Amin, S. 2009. "Renewing Development Paradigms for the XXIst Century"; paper for CODESRIA Brainstorming Workshop on New Directions and Priorities for Research; July 2009.

Amin, S. 2007. "Reflections: Samir Amin Interviewed by Amady Aly Dieng" in Development and Change 38 (6): 1149-1159 (2007).

Boulaga, F. E. 2009. "Priorités de recherches et nouvelles directions"; paper for CODESRIA Brainstorming Workshop on New Directions and Priorities for Research; July 2009.

CODESRIA 2009. "New Directions and Priorities for Research." Think-Pieces for a Brainstorming Workshop; Dakar: CODESRIA, mimeo.

CODESRIA 2007. Rethinking Development and Reviving Development Thinking in Africa. Strategic Plan for 2007-2011.

CODESRIA 2012. Extending the Frontiers of Social Research and Knowledge Production, and Bringing Research to Public Issues. Strategic Plan for 2012-2016

Burawoy, M. 2007. "Open the Social Sciences: To Whom and for What?", in Portuguese Journal of Social Science, Vol. 6, No.3.

Cheru, F. and Obi, C. (ed) 2010. The Rise of India and China in Africa. London: Zed

Charter for Humanities and Social Sciences (CHSS) 2012. Report Commissioned by the Minister of Higher Education and Training for the Charter for Humanities and Social Sciences (CHSS); Pretoria: Department of Higher Education and Training, Republic of South Africa.

Chatterjee, P. 1986. Nationalist Thought and the Colonial World: A Derivative Discourse? London: Zed Books for the United Nations University.

Comaroff, J. and Comaroff J. 2011. Theory from the South: Or, How Euro-America is Evolving Toward Africa (The Radical Imagination). New York: Paradigm Publishers.

Concertation nationale sur l'avenir de l'enseignement superieur au Senegal (CNAES), 2013. Reorienter le systeme d'enseignement superieur au Senegal. Pre-rapport de la CNAES. Dakar: Republic du Senegal.

Copans, J. 1990. La longue marche de la modernité africaine: savoirs, intellectuels, democratie. Paris, Karthala.

Diouf, M. and Mamdani, M. 1994. Academic Freedom in Africa. Dakar: CODESRIA.

Dussel, E. 1995 [1976]. The Invention of the Americas: Eclipse of the Other and the Myth of Modernity (Translated by Michael D. Barber). New York: Continuum.

Hyden, G. 1983. No Shortcuts to Progress. African Development Management in Perspective. Berkeley: Berkeley University Press.

Ibrahim Index of African Governance (IIAG) 2010. London: Mo Ibrahim Foundation. Imam, A., Mama, A. \& Sow, F. 1996. Engendering Social Sciences in Africa; Dakar: CODESRIA. 


\section{INDEX}

Adaptation 5

AEGIS 12

African Studies 1, 3, 6, 7, 8, 9, 10, 12, $13,14,28,47,48,52,53,60$, $64,65,66,87,92,143,173$, 193

AIDS HIV 30, 46, 48, 49, 50, 88, 93, $97,106,116,153$

African National Congress (ANC) $10,144,145,146,147,148$, $149,151,152$

Angola 92, 94, 96

Anthropology 7, 13, 14, 91, 94

Apartheid 3, 10, 68, 69, 72, 73, 74, $76,77,83,84,144,145,147$, $148,149,151$

Archive vii, 9, 51, 64

Archive of Migrant Memories 9, 51,64

Asia 26, 86, 94, 126, 146, 198

Automobile 160, 168

Band Aid 4

Bénard da Costa, Ana 8, 13

Biza, Adriano i, 8, 13, 27

Blue Nile 51

Brazil 2, 44, 48, 88, 147, 176, 178, $179,193,208,210,213$

BRICS 2, 88, 147, 179, 197, 210, 212, $213,214,215$

Burkina Faso 105

Burundi 105, 147, 160, 170

Chad 94, 105

Chanie, Paulos 11, 118

China $2,7,86,88,97,144,147,154$, $156,157,160,163,166,169$, $170,173,174,176,178,179$, 192, 194, 207, 210, 211, 212, $213,214,215,216$

CODESRIA $12,193,195,196,197$, 198, 199, 200, 201, 202, 204, 206, 207, 208, 211, 212, 213,
$214,215,216$

Cognitive 7, 128

Cold War 2, 7

Corporate social responsibility

(CSR) 9, 89, 95

Côtéman 37

Dakar vi, 33, 36, 38, 41, 42, 47, 48, 49, 50, 193, 196, 198, 202, 209, 215,216

Darfur 55, 59, 203

Davies, John 154, 155, 156, 157, 163, 169

Democratic Republic of Congo 104, 109, 203, 205

Denmark 67

Derg 55

Development Assistance Committee (DAC) 87

Development knowledge 176, 180, 191

Durban 3, 47, 200

East Africa 10, 50, 125, 129, 138, $164,166,170,173,174$

Economics 7, 14, 49, 91, 179, 208

Egypt 58, 118, 164, 196

End of history i, 9, 67, 68, 69, 70, 72, 76,182

Engel, Ulf 1, 7, 12, 181, 192

Eritrea 55, 56

Ethiopia 9, 10, 51, 55, 56, 65, 66, 104, $105,118,123,125,127,128$, $131,136,160,162,165,166$, $167,170,171,173,196,208$

Ethiopian 51, 58, 66, 166, 196

Europe 7, 12, 37, 38, 52, 54, 56, 59, $79,85,108,119,126,198,203$ Fertility 11, 97, 98, 99, 102, 106, 107, $108,110,111,112,113,114$, 115

Fukuyama, Francis 9, 12, 67, 70, 71, $72,75,85,86$ 
Globalization 5, 66, 147, 153

Global Partnership for Social Accountability $10,175,176$

Global South 7, 199, 213

Great Lakes region 159, 172

Highway 157, 158, 172

Home Space 8

Honwana, Alcinda 8, 29, 48

Horn of Africa vi, 51, 55, 58, 59, 66, 166

Humanitarian 52, 53, 59, 60, 189

India $2,88,97,110,116,147,160$, $170,179,192,193,210,216$

Indian Ocean 53, 65, 154, 159, 160, $162,163,170,171$

Informal (economy) 15, 27, 58, 63

Intergovernmental Panel on Climate Change (IPCC) 108

international aid $10,114,175$ )

International Association for Development (IAD 87

International Labour Organization (ILO) 100

International Monetary Fund (IMF) 87

Intimacy i, 8, 30, 32, 40, 46

Italy $9,51,58,59,60,61,63,64$

Italian 51, 58, 59, 60, 61, 181

Kaarsholm, Preben 10, 53, 65, 144, 153

Kenya 173

Kenya Port Authority (KPA) 159

Lamont, Mark 10, 154, 159, 160, 161,173

LAPSSET $10,171,172,173$

Macamo, Elísio 10, 175, 179, 186, 193, 203

Machamba 17, 18, 22, 24

Malaria 88, 106

Mali 105, 106, 109, 116, 196, 203, 206, 211

Maputo 5, 8, 13, 14, 16, 17, 18, 26,
$27,28,32,33,46,48,49,186$

Marikana 10, 144, 145, 146, 147, $148,149,150,153$

Maternal mortality 107

Menelik 55

Middle East 26, 29, 48, 50, 54

Migrants 9, 51, 52, 53, 54, 56, 57, 58, $59,60,61,64,74,81,82,151$

Mihyo, Pascal B. 11, 118

Military 7, 56, 58, 173, 201

Mokni, Jamel 41

Morocco 118, 209

Mozambique 5, 13, 20, 28, 30, 38, $46,47,48,49,94,104,179$, 186, 193

Multipolar (Multipolarity) 1, 154, $155,156,157,163,169,195$

Muslim 41, 48

Nation-state $10,55,85,154,158$, $167,170,171$

Neo-liberalism 10, 158, 167, 170, 171

Networking 7, 132, 139, 197

NGO 60, 62, 95, 96

Niger 105

Nigeria 91, 94, 104, 121, 142, 173, 196

North America 7, 119, 126, 198, 203

North-South 138, 214

Norway 3, 4, 12

Norwegian Students' and Academics' International Assistance Fund (SAIH) 3

Nugent, Paul 7, 12, 54

Organisation for Economic Co-operation and Development (OECD) 87

Organization of African Unity (OAU) 1

Paris Declaration 178, 186

Pires de Carvalho, Ana 11, 12, 97, 117 
Politics 4, 6, 10, 28, 86, 96, 145, 146, $147,152,154,162,163,170$, $171,173,176,177,179,180$, $181,184,185,189,191,192$, 193, 201, 204

Post-modern 7, 9, 67, 77, 78, 80

Psychology 7

Public health 93

Radi-Aid 3, 4, 12

Railway 59, 60

Ramos, Manuel João 1

Refugees 9, 51, 52, 65

RESSESA $11,12,118,123,140,141$, 142,208

Road 10, 66, 113, 154, 156, 157, 158, 173

Road safety v, 158

Russia 2, 88, 147, 150, 179

Sall, Ebrima 12, 118, 121, 143, 195, 201,211

Sexuality 30, 31, 33, 41, 42, 43, 45, $47,48,49,50,148$

Social sciences $6,91,140,141,199$, 200, 201, 204, 205, 207, 208, 209

Somalia 56, 59, 71, 160, 164, 167, 170,172

South Africa 2, 10, 16, 17, 20, 30, 34, $43,46,47,48,49,68,83,86$, $88,91,118,121,135,139,144$, $146,147,148,149,150,151$, $152,153,158,179,193,196$, $200,205,206,208,209,216$

South-South 138, 204, 213, 214

South Sudan 10, 160, 162, 165, 166, $167,170,171,173$

Spain 57,58

State-building 9, 67

Sudan $10,55,56,58,123,125,128$, $131,134,135,138,154,159$, $160,162,164,165,166,167$, $170,171,173$
Tallio, Virginie 9-12, 87-96, 93-96, 96

Tiburtina 59, 60, 61, 62, 63, 64

Transdisciplinarity 6

Triulzi, Alessandro 9, 51, 65

Tuberculosis 88

Tunis 34, 36

Tunisia v, 30, 39, 40, 41, 42, 48

UNAIDS 46

United Nations (UN) 29, 50, 87, 88, 92, 97, 98, 99, 100, 101, 102, $103,104,105,106,108,111$, $115,117,216$

United Nations Children Fund (UNICEF) 98, 101, 102, 105, 106, 108

United Nations Development Program (UNDP) 87, 100

United Nations Human Settlements Fund (UN-Habitat) 102, 103, 104

Urban anthropology 14

Urbanization 2, 6, 47, 86, 101, 102, 103,116

Violence $10,43,48,60,80,99,110$, $144,145,149,161,171$

Virginity 39, 40, 41, 42, 45

Vision 2030 154, 156, 158, 159, 160, $161,168,171,172$

Waithood 8, 29, 30, 32, 34, 43

World Bank (WB) 10, 29, 50, 87, $101,110,112,119,120,121$, $143,157,174,175,176,177$, $180,193,211$

World Health Organization (WHO) 88

World Heritage 164, 17

YouTube 3

Zimbabwe 49, 104, 123, 128, 131, $135,138,211$ 
